ANALYSIS OF TOXIC AND NON-TOXIC ALEXANDRIUM

(DINOPHYCEAE) SPECIES USING RIBOSOMAL RNA GENE

SEQUENCES

by

Christopher Alan Scholin

B.A. University of California at Santa Barbara (1984)

M.A. Duke University (1986)

SUBMITTED IN PARTIAL FULFILLMENT OF THE REQUIREMENTS FOR THE DEGREE OF DOCTOR OF PHILOSOPHY

at the

MASSACHUSETTS INSTITUTE OF TECHNOLOGY

and the

WOODS HOLE OCEANOGRAPHIC INSTITUTION

November 1992

CChristopher A. Scholin 1992

The author hereby grants to MIT and WHOI permission to reproduce and distribute copies of this thesis in whole or in part.

Signature of Author

Joint Program in Biological Oceanography Massachusetts Institute of Technology/

Woods Hole Oceanographic Institution

Certified by

Donald M. Anderson

$\cap \cap \cap D$. Thesis Supervisor

Accepted by
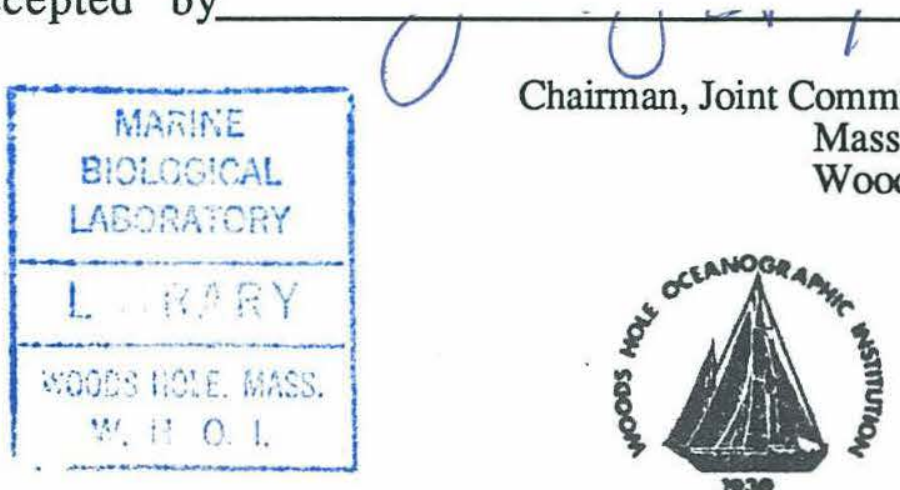

John J. Stegeman

iological Oceanography

Massachusetts Institute of Technology/

Woods Hole Oceanographic Institution 


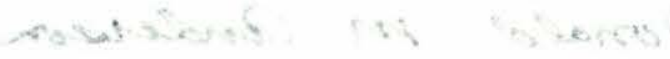




\title{
ANALYSIS OF TOXIC AND NON-TOXIC ALEXANDRIUM (DINOPHYCEAE) SPECIES USING RIBOSOMAL RNA GENE SEQUENCES
}

\author{
by \\ Christopher Alan Scholin
}

submitted in partial fulfillment of the requirements for the degree of Doctor of Philosophy

\begin{abstract}
Sequences of small subunit (Ss) and large subunit (Ls) ribosomal RNA genes (rDNA) from the marine dinoflagellates Alexandrium tamarense, $\underline{\text { A. catenella, }} \underline{\mathrm{A}}$. $\underline{\text { undyense}}, \underline{\mathrm{A}}$. affine, $\underline{\mathrm{A}}$. minutum, $\underline{\mathrm{A}}$.

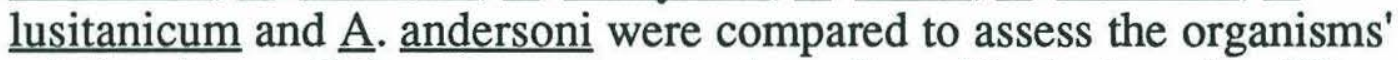
relationships. Cultures represent isolates from North America, Western Europe, Thailand, Japan, Australia and the ballast water of several cargo vessels, and include both toxic and non-toxic strains. An emphasis was placed on the $\underline{\mathrm{A}}$. tamarense/catenella/fundyense "species complex," a group of morphotypically-similar organisms found in many regions of the world.

Two distinct SsrRNA genes, termed the "A gene" and the "B gene," were found in a toxic $\underline{A}$. fundyense isolated from eastern North America. The $\mathrm{B}$ gene is considered to be a pseudogene. A restriction fragment length polymorphism (RFLP) assay developed to detect the A and B genes revealed five distinct groups of Alexandrium isolates. Three subdivide the

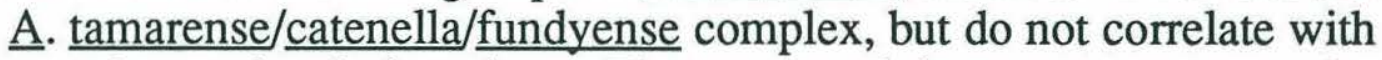
morphospecies designations. The two remaining groups are associated with cultures that clearly differ morphologically from the $\underline{\mathrm{A}}$. tamarense/ catenella/fundyense group: the fourth group consists of $\underline{\mathrm{A}}$. affine isolates, and the fifth group is represented by $\underline{\mathrm{A}}$. minutum, $\underline{\mathrm{A}}$. lusitanicum and $\underline{\mathrm{A}}$. andersoni. The B gene was only found in $\underline{A}$. tamarense/catenella/ fundyense, but not in all members of this species complex. The B gene is not uniformly distributed among global populations of Alexandrium. All

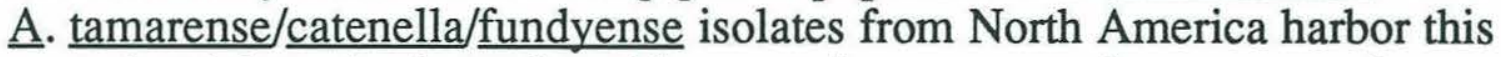
gene, but it has also been found in some $\underline{A}$. tamarense from scattered locations in Japan, as well as in A. tamarense from the ballast water of one cargo vessel which was on a defined run from Japan to Australia. The B gene may be endemic to North American populations of $\underline{\mathrm{A}}$. tamarense/
\end{abstract}


catenella/fundyense. It is possible that in the recent past North American A. tamarense were introduced to Japanese waters, and cysts of these organisms have been transported from Japan to Australia.

A subset of isolates examined using the the RFLP assay were also compared by cloning and sequencing a fragment of their LsrDNA. Eight major classes of LsrDNA sequences, termed "ribotypes," were identified. Five ribotypes subdivide members of the $\underline{A}$. tamarense/catenella/fundyense complex; all isolates containing the $\mathrm{B}$ gene cluster as one ribotype. The three remaining ribotypes are typified by: 1) $\underline{A}$. affine; 2$) \underline{A}$. minutum and $\underline{\mathrm{A}}$. lusitanicum; and, 3) $\underline{\mathrm{A}}$. andersoni. LsrDNAs from $\underline{\mathrm{A}}$. minutum and $\underline{\mathrm{A}}$.

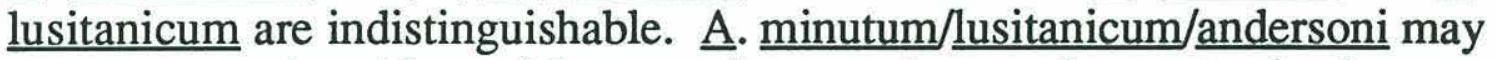
represent another Alexandrium species complex, analogous to the $\underline{A}$. tamarense/catenella/fundyense group. An organisms' ability to produce toxin appears to be correlated with its LsrDNA phylogenetic lineage. Ribotypes ascribed by the LsrDNA sequences are in complete agreement with, and offer a finer-scale resolution of, groups defined by SsrDNA restriction patterns. The SsrDNA RFLP groups and LsrDNA ribotypes are useful species- and population-specific markers.

Alexandrium tamarense/catenella/fundyense exist as geneticallydistinct "strains" (populations), not three genetically-distinct species: representatives collected from the same geographic region appear the most similar, regardless of morphotype, whereas those from geographicallyseparated populations are more divergent even when the same morphospecies are compared. Contrary to this general pattern, $\underline{\mathrm{A}}$. tamarense/catenella from Japan were found to be exceptionally heterogeneous. Ballast water samples show that viable cysts (resting

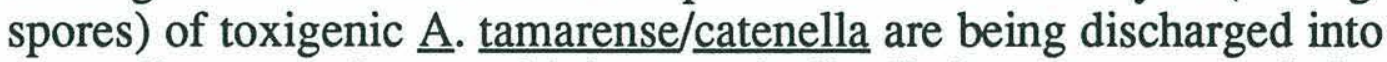
Australian ports from multiple, genetically-distinct source populations.

The rDNA sequences were also used to test theories accounting for the evolution and global dispersal of $\underline{\mathrm{A}}$. tamarense/catenella/fundyense. Results suggest a monophyletic radiation of these organisms from a common ancestor that included, or gave rise to, multiple morphotypes. Populations appear to have diverged as a result of vicariance (geographic isolation). The co-occurrence of genetically-distinct strains of these organisms is an indication of dispersal. An example of this is seen in Japan where an introduction of North American $\underline{A}$. tamarense appears likely. Determining the timing of dispersal events is problematic if based strictly on rDNA sequence similarities, since these molecules undergo change on a scale of millions of years. Thesis Supervisor: Donald M. Anderson 
For $\mathrm{Ma}, \mathrm{Pa}$ and $\mathrm{Ed}$ 


\section{TABLE OF CONTENTS}

ABSTRACT iii

DEDICATION $\quad$ v

ACKNOWLEDGEMENTS $\quad$ xi

BIOGRAPHICAL NOTES xii

INTRODUCTION 1

$\begin{array}{ll}\text { Literature Cited } & 8\end{array}$

CHAPTER 1: Two Distinct Small-Subunit rRNA Genes

in the North American Toxic Dinoflagellate

Alexandrium fundyense (Dinophyceae) 15

$\begin{array}{ll}\text { Abstract } & 16\end{array}$

Introduction 17

Materials and Methods $\quad 20$

Results 24

Sequences of the A and B genes 26

RTase sequencing of SsrRNA from $\underline{A}$. fundyense $\quad 30$

Discussion 29

$\begin{array}{ll}\text { Literature Cited } & 36\end{array}$

CHAPTER 2: Identification of Group- and Strain-Specific

Genetic Markers For Globally Distributed Alexandrium

(Dinophyceae) Species. I. Restriction Fragment Length

Polymorphism Analysis of Small-Subunit Ribosomal RNA Genes 41

$\begin{array}{ll}\text { Abstract } & 42\end{array}$

Introduction 44

Materials and Methods $\quad 48$

List of cultures and RFLP assay characteristics $\quad 50$

Results 53

Composite restriction maps of the A and B genes $\quad 55$

A/B restriction test: schematic and agarose gels $\quad 56$

Summary of RFLP group characteristics 58 
CHAPTER 2 Results (contd.)

Groups I-III: subdivisions of the Alexandrium

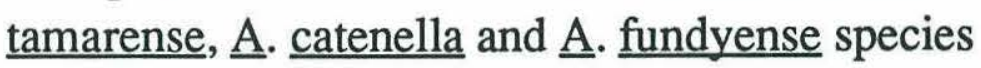
complex

Group IV: Alexandrium affine

Group V: Alexandrium minutum, $\underline{\text { A. }}$ lusitanicum and $\underline{\mathrm{A}}$. andersoni

60

Discussion

60

The $\mathrm{A} / \mathrm{B}$ restriction test

61

Groups I-III: strains of Alexandrium tamarense,

A. catenella and $\underline{A}$. fundyense

63

The B gene's relationship to morphospecies

designations and toxicity

65

Biogeography

67

The Alexandrium affine and the $\underline{A}$. minutum/

lusitanicum/andersoni groups

68

Conclusions

70

Literature Cited

71

CHAPTER 3: Identification of Group- and Strain-Specific Genetic Markers For Globally Distributed Alexandrium (Dinophyceae) Species. II. Sequence Analysis of a Fragment of the Large-Subunit Ribosomal RNA Gene

Abstract

78

Introduction

80

Materials and Methods $\quad 81$

List of cultures $\quad 82$

Sequencing strategy for LsrDNA clones $\quad 88$

Results

91

Amplification, cloning and alignment of LsrDNA

fragments

91

Proposed LsrDNA sequence alignment

93

Phylogenetic analyses of aligned LsrDNAs

101

LsrDNA parsimony phylogenetic tree

102

Parsimony bootstrap consensus tree 
CHAPTER 3 Results (contd.)

Definition of Alexandrium ribotypes 106

Comparison of Alexandrium SsrDNA RFLP patterns and LsrDNA ribotypes (Table)

Discussion

Comparisons of Alexandrium SsrDNA RFLP patterns and LsrDNA sequences

Alexandrium LsrDNA ribotypes and their relation to toxicity

The Alexandrium tamarense/catenella/fundyense complex

The Alexandrium affine and the $\underline{\text { A. minutum/ }}$ lusitanicum/andersoni complexes

Morphological, enzyme electrophoretic and toxin composition analyses: re-evaluation of conflicting conclusions

Alexandrium tamarense/catenella/fundyense and the species concept

Concluding remarks

Literature Cited

CHAPTER 4: Towards an Understanding of the Evolution and Global Dispersal of Toxic Dinoflagellates within the $\underline{\text { Alexandrium tamarense/catenella/fundyense "Species Complex" }}$

Abstract

Introduction

Results

LsrDNA parsimony phylogenetic tree of selected Alexandrium tamarense/catenella/fundyense and A. affine LsrDNA sequences

Comparison of geographic regions, and isolated Alexandrium species along with their toxicity and rDNA characteristics 
CHAPTER 4 Results (contd.)

Direct sequencing of PCR-amplified SsrDNA from North American, Western European, Tasmanian and Temperate Asian representatives

Discussion

Evolution of the Alexandrium tamarense/catenella/ fundyense complex

Hypothetical models accounting for the evolution of the Alexandrium tamarense/catenella/fundyense species complex, and their respective phylogenetic predictions

Evolution of the B gene: morphospecies and population specificity

Endemism of North American Alexandrium tamarense/catenella/fundyense

Possible origins of Japanese Alexandrium tamarense/ catenella heterogeneity

Dispersal of toxic Alexandrium species to Australia 155

Materials and Methods

Literature Cited

CHAPTER 5: Summary and Conclusions

CHAPTER 6: Suggestions for Further Study

A. Clarification of Morphotaxonomy 180

B. Evolution, Population Biology and Dispersal 181

C. Sexual Compatibility and Meiotic Partioning of Genes 187

D. Molecular Detection of Strains, Species and Genera 188

E. Genetic Basis of Toxin Production 189 
APPENDIX A: Selected Protocols (contd.)

T/A Miniprep (Modified Birnboim): Screening Clones and Preparing Template for ds Plasmid Sequencing dsDNA Sequencing of Recombinant T/A Plasmids Magnetic Bead Preparation of Biotynlated PCR Products for Sequencing

Alexandrium RNA Extraction: $\mathrm{LiCl}_{2}$ Precipitation

Reverse Transcriptase-mediated Sequencing of rRNA

Intra-A and Intra-B Gene Variation

List of Restriction Enzymes, Predicted Cleavage Sites and Expected Products of Digestion for the A and B Genes from $\underline{\text { A. fundyense }}$ (GtCA29)

Characterization of Larger, Minor SsrDNA PCR Products

Found in "Group I" Alexandrium Isolates

Description of Alexandrium Subribotypes 236

Notes on Alexandrium LsrDNA Sequence Alignment 238 Interpretation of Fine-Scale Alexandrium LsrDNA Sequence Variations

Alexandrium LsrDNA Genomic Heterogeneity 242 methodological artifacts 243 contamination versus genomic variation 244 intra-organismal LsrDNA variation 245 genomic variation versus expressed variation $\quad 250$ 


\section{ACKNOWLEDGEMENTS}

This thesis would not have been possible without the help, encouragement and support of many people from all walks of life. To those in the academic community, I am forever in your debt for your financial assistance and technical advice. In particular, Don Anderson, Penny Chisholm, Ed Delong, Gustaaf Hallegraeff, Michel Herzog, Judy McDowell, Doug Prasher, Mitch Sogin, Norm Wainwright and John Waterbury deserve special mention for their time, patience and genuine interest in my work. I would also like to thank members of the Anderson Lab: Greg Doucette, Bruce Keafer, John Kokinos and Dave Kulis, for their help and companionship. Special thanks to the University of California, Santa Cruz, and U.C.S.C.'s Institute of Marine Sciences for providing an office space where I processed most of the sequence data and wrote a significant fraction of Chapters 2 and 3. Bob Hudson kindly provided access to computing facilities at U.C.S.C. Abbie Jackson and other members of the W.H.O.I. Education Office were especially helpful in the final stages of submitting this thesis.

To the sailing community of the Cape and Islands, and the many friends of Great Harbor, I owe a warm-hearted thanks for sharing one of the most beautiful places on earth. And thanks also to the good ship PHOTON for her shelter, and the adventure of a lifetime. To my closest friends and family - Joe Aldelstien, Harbor Andy, Zlex Boccencelli, Andy Bowan, Raffaella Cosotti, Diane Cowan, Carla Curran, Jean and Gretchen Dunoyer, Peter Franks, the Frickes, Jake and Anna Maria Peirson, Eden Rue ( $\left.C^{2} R P\right)$, Juan Salzig, Leala Sayigh, Ma and Pa Scholin, Susan Wijffels, Erik Zettler, and so many others - I owe my greatest thanks and admiration, for it is you who supported me and made me laugh when I approached critical mass.

This work was supported in part by a grant from the National Science Foundation to D. M. Anderson (contract number OCE8911226), the Woods Hole Oceanographic Institution Ocean Ventures Fund and the Woods Hole Oceanographic Institution Education Office. 


\section{BIOGRAPHICAL NOTES}

Christopher Alan Scholin was born in St. Louis, Missouri, on September 25, 1961. Chris began his academic career at the University of Missouri, Columbia, in 1979 with a declared major in Forestry and Wildlife. Deciding that marine science was more to his liking, he transferred to the University of California, Santa Barbara, in 1981 where he began a study of marine ecology. After changing majors several times, and only one class short of graduating with a double degree in Biology and Environmental Studies, Chris took a keen interest in molecular genetics. After an additional year of biochemistry, bacterial genetics and an introduction to recombinant DNA technology, Chris graduated from U.C.S.B. in 1984 with a B.A. (hons.) in Biology. Focussed on the molecular aspects of life, he moved to Duke University and began a study of mammalian gene expression. Chris left Duke in 1986 with a M.A., tired of growing cancerous mouse cells, and determined to unite the disciplines of molecular biology and marine ecology. In 1987, he joined Dr. D. M. Anderson's lab, and the M.I.T/W.H.O.I. Joint Program in Biological Oceanography. Five years and many dinoflagellate rDNA sequences later, Chris hopes to bring physical oceanographic and engineering aspects into his research activity. 


\section{Introduction}


Throughout the world's oceans, thousands of species of phytoplankton form the base of the marine food chain. Among these are a few dozen which are harmful to mankind. The negative impacts of their "blooms" (sometimes called "red tides") are extraordinarily diverse, ranging from public health threats due to toxic fish or shellfish, to destruction of marine life and significant economic loss. In recent times, the list of known, harmful phytoplankton species has grown, new phytoplankton toxins have been discovered, and the frequency of harmful blooms and their geographic range appears to be expanding (Anderson 1989, Smayda 1990). Part of the difficulty in understanding the relationships between toxic and non-toxic phytoplankton species, their mechanisms of toxigenesis, and their bloom dynamics, population structure and apparent dispersal lies in the lack of methods that allow for unambiguous identification of the species in question.

Studies of marine dinoflagellates of the genus Alexandrium (formerly Protogonyaulax; Steidinger and Moestrup 1990) epitomize this problem. Some, but not all, representatives of this diverse group produce toxins responsible for paralytic shellfish poisoning, a neurotoxic disorder that has caused human illness for centuries and claimed hundreds of lives ( Quayle 1969, Prakash et al. 1971). Like other harmful phytoplankton, toxigenic Alexandrium appear to be dispersing to regions of the world previously free of their presence (Anderson 1989, Hallegraeff and Bolch 1991, 1992). In some cases, populations of the same or similar species occur in different regions of the world, yet little is known of their genetic affinities. These and 
other problems have brought Alexandrium species under intense international scrutiny, with taxonomy, biogeography, and elucidation of factors essential for bloom formation and toxigenesis among the top research priorities. All of these themes share an absolute requirement for unequivocal definition of the organisms' inter- and intra-specific relationships, and in each case would benefit from rapid and simple assays to detect Alexandrium species, or strains of species, in culture or field samples. This thesis has grown from this collective need: it represents a step towards the application of molecular biological methods as a means of identifying toxic and non-toxic Alexandrium species, and delineating globally-distributed populations.

At present, Alexandrium taxonomy relies on detailed descriptions of the morphology of vegetative cells and their zygotic resting cysts (Taylor 1984, 1985, Balech 1985, Balech and Tangen 1985). Continual re-evaluation of these characters has altered the group's generic and species concepts, leaving a legacy of confusing taxonomic designations (Taylor 1984, 1985, Balech 1985, Steidinger 1990). A consensus to use the Alexandrium genus designation was only reached in 1989 (Steidinger and Moestrup 1990); however "species" and "strain" (i.e., sub-species) criteria continue to be a subject of debate (Taylor 1985, 1990, Hallegraeff et al., 1991). An example of this centers on the "․․ tamarense, $\underline{\text { A. }}$ catenella and $\underline{\mathrm{A}}$. 
fundyense species complex." 1 All three species are typically toxic, although their inherent toxicity can vary significantly (Maranda et al. 1985, Cembella et al. 1987). In fact, some isolates of $\underline{A}$. tamarense produce no toxin (Destombe et al. 1992). Taxonomic authorities agree that $\underline{\mathrm{A}}$. $\underline{\text { tamarense, }} \underline{\mathrm{A}}$. catenella and $\underline{\mathrm{A}}$. $\underline{\text { fundyense }}$ are closelyrelated. Their distinction as "species" is based on fine-scale features amidst a background of similar morphology (Balech 1985, Balech and Tangen 1985, Fukuyo 1985). Some authorities believe that these morphological differences warrant the use of unique species assignments, while others argue that the morphological variants represent strains, or "varieties," of a single species (Balech 1985, Fukuyo 1985, Taylor 1985, Cembella and Taylor 1986, Cembella et al. 1987, 1988, Hayhome et al. 1989). The disagreement over fine-scale taxonomic indicators inspired a search for a morphologicallyindependent means of determining these species' genetic affinities. Isozyme electrophoresis, toxin composition analyses and cell reactivity towards monoclonal antibodies (Cembella et al. 1987, 1988, Hayhome et al. 1989, Sako 1992, Sako et al. 1990, 1992) have all been applied to assess the different morphospecies' relatedness. However, the conclusions of these investigations are not consistent: in some cases, groups defined by morphotype are the same as those defined by biochemical means (Sako et al. 1990, Sako 1992), but in other cases they are not (Cembella and Taylor-1986;- Cembella et al. 1987, 1988; Hayhome et al 1989). Thus, results of sub-cellular

1 In the past, these species have been referred to as the "tamarensis group," or "tamarensis/catenella complex;" throughout this text they are referred to as the "tamarense/catenella/fundyense complex," since all three are closely-related. 
characterizations used in an attempt to settle the morphotaxonomic debate are in conflict, and the relationship between "morphotype" (the ensemble of genes responsible for morphology) and "genotype" (sub-cellular characters such as allozymes, toxin compositions, etc.) remains obscure.

Conclusions regarding the "validity" of morphospecies designations, and the overall genetic similarity of $\underline{\text { A.tamarense/ }}$ catenella/fundyense, seem to depend on the geographic origin of isolates (Sako et al. 1990, Cembella et al. 1988, Hayhome et al 1989). The confusion over morphotype and its relation to cells' subcellular characteristics may arise because geographically-separated populations of the same morphospecies are genetically-divergent. That is, that globally-distributed populations may share a higher degree of morphological similarity than biochemical similarity. An understanding of, and resolution to, the taxonomic controversy therefore appears to require definition of genetic relationships among globally-distributed representatives of $\underline{\text { A.tamarense/ }}$ catenella/fundyense. In turn, questions concerning these organisms' dispersal should be approachable.

Sequence analysis of small subunit (Ss) and large subunit (Ls) ribosomal RNA genes (rDNA) was undertaken in an effort to address these problems. Ribosomal RNA and DNA sequences have been used extensively as phylogenetic and taxonomic indicators (Olsen et al. 1986, Field et al. 1988, Sogin et al. 1986, Lenaers et al. 1988, 1989). These genes are composed of "domains" which are both highly conserved and highly variable among all organisms (Gobel et al., 
1987; Sogin and Gunderson 1987; Raue' et al. 1988, Mitchot et al. 1984, Mitchot and Bachellerie 1987). The conserved and variable elements are valuable for both broad- and fine-scale taxonomic and phylogenetic comparisons, respectively. Some of the fastest evolving rDNA domains ("hypervariable regions") have been employed as species- and even strain-specific markers (e.g., Gobel et al. 1987, McCutchan 1988, Qu et al. 1988, Stahl et al.1988, Guadet et al. 1989, Gueho et al. 1989; Distel et al.,1991; Lenaers et al., 1991; Peterson and Kurtzman, 1991, Rowan and Powers 1991). The demonstrated utility of rDNA sequence analysis made this an attractive option for attempting to delineate toxic and non-toxic Alexandrium species and populations. A further incentive was the potential of developing rRNA/DNA-targeted probes as a rapid means of detecting these organisms, either in an extracted nucleic acid formats or whole cell hybridizations (e.g., Giovannoni et al. 1988, McCutchan et al. 1988, Stahl et al. 1988, DeLong et al., 1989, DeLong and Shah. 1990, Amann et al. 1990 a and b, Distel et al, 1991, Zarda et al 1991).

Several different strategies were used to elucidate Alexandrium rDNA sequences, each of which has its own advantages, limitations and technical difficulties. Chapter 1 documents the first attempt at determining the complete SsrDNA sequence for a toxic, eastern North American $\underline{A}$. fundyense. Surprisingly, this isolate was found to harbor two distinct classes of SsrRNA genes, one of which does not produce stable transcripts and is considered to be a pseudogene. Chapter 2 describes a restriction fragment length polymorphism (RFLP) assay that was developed to screen $\underline{\text { Alexandrium }}$ 
isolates for the two classes of SsrRNA genes, and reports on the utility of these markers as taxonomic and biogeographic indicators. In Chapter 3, questions of taxonomy and biogeography were addressed in greater detail by sequencing a fragment of LsrDNA from a diverse collection of Alexandrium isolates, and by using the sequences to construct a phylogenetic tree. The LsrDNA sequences offer promising targets for genus-, species- and strain-specific oligonucleotide probes; thus, rapid and highly-specific assays for a variety of these organisms at various levels of taxonomic organization may now be in reach. In an effort to place the findings of Chapts. 1 - 3 in a context useful for addressing dispersal hypotheses, a theoretical, evolutionary perspective for the $\underline{A}$. tamarense/catenella/fundyense complex is presented in Chapter 4. Finally, a summary of this work is given in Chapter 5, and considerations for future research are presented in Chapter 6 .

The questions that prompted this investigation encompass Alexandrium taxonomy, population biology, dispersal, and a need for methods that allow rapid and specific detection of cells in complex field samples. These same problems are common to a host of harmful algal species. The experimental approaches employed in this study should be applicable to many, if not all, of these organisms. 


\section{Literature Cited}

Amann, R.I., Krumholz, L., Stahl, D. A. (1990 a). Fluorescentoligonucleotide probing of whole cells for determinative, phylogenetic and environmental studies in microbiology. J. Bact. 172:762-770.

Amann, R.I., Binder, B.J., Olson, R.J., Chisholm, S.W., Devereux, R., Stahl, D.A. (1990b). Combination of 16S rRNA-targeted oligonucleotide probes with flow cytometry for analyzing mixed microbial populations. Appl. Environ. Microbiol. 56:1919-1925.

Anderson, D.M. (1989). Toxic algal blooms and red tides: a global perspective. In : Okaichi,T., Anderson, D.M., and Nemoto,T. (eds.) Red tides: biology, environmental science and toxicology. Elsevier, New York, pp. $11-20$.

Balech, E. (1985). The genus Alexandrium or Gonyaulax of the tamarensis group. In : Anderson, D.M., White, A.W., Baden, D.G. (eds.) Toxic Dinoflagellates. Elsevier, New York, pp. 33 - 38.

Balech, E., Tangen, K. (1985). Morphology and taxonomy of toxic species in the tarmarensis group (Dinophyceae): Alexandrium excavatum (Braarud) comb. nov. and Alexandrium ostenfeldii (Paulsen) comb. nov. Sarsia 70: 333-343.

Cembella, A.D., Taylor, F.J.R. (1986). Electrophoretic variability within the Protogonyaulax tamarensis/catenella species complex: pyridine linked dehydrogenases. Biochem. Syst. and Ecol. 14: 311-323.

Cembella, A.D., Sullivan, J.J., Boyer, G.L., Taylor, F.J.R., Andersen, R.J. (1987). Variation in paralytic shellfish toxin composition within the Protogonyaulax tamarensis/catenella species complex: red tide dinoflagellates. Biochem. Syst. and Ecol. 15: 171-186.

Cembella, A.D., Taylor, F.J.R., Therriault, J.-C. (1988). Cladistic analysis of electrophoretic variants within the toxic dinoflagellate genus Protogonyaulax. Botanica Marina 31: 3951. 
Delong, E.F., Wickham, G.S., Pace, N.R. (1989). Phylogenetic stains: ribosomal RNA-based probes for the identification of single cells. Science 243:1360-1363.

Delong, E.F., Shah, J. (1990). Fluroescent, ribosomal RNA probes for clinical application: a research overview. Diagnostics and Clinical Testing 28:41-44.

Destombe, C., Cembella, A.D., Murphy, C.A., Ragan, M.A. (1992). Nucleotide sequence of the $18 \mathrm{~S}$ ribosomal RNA genes from the marine dinoflagellate Alexandrium tamarense (Gonyaulacales, Dinophyta). Phycologia 31: 121-4.

Distel, D.L., DeLong, E.F., Waterbury, J.B. (1991). Phylogenetic characterization and in situ localization of the bacterial symbiont of shipworms (Teredinidae: Bivalvia) by using $16 \mathrm{~S}$ rRNA sequence analysis and oligonucleotide probe hybridization. Appl. Environ. Microbiol. 57:2376-2382.

Field, K.G., Olsen, G.J., Lane, D.J., Giovannoni, S.J., Ghiselin, M.T., Raff, E.C., Pace, N.R. \& R.A. Raff. 1988. Molecular phylogeny of the animal kingdom. Science 239:748-53.

Fukuyo, Y. (1985). Morphology of Protogonyaulax tamarensis (Lebour) Taylor and Protogonyaulax catenella (Whedon and Kofoid) Taylor from Japanese coatal waters. Bull. Marine Science. 37: 529-537.

Giovannoni, S. J., Delong, E. F., Olsen, G. J., Pace, N. R. (1988). Phylogenetic group-specific oligodeoxynucleotide probes for identification of single microbial cells. J. Bact. 170:720-726.

Gobel, U.B., Geiser, A., Stanbridge, E.J. (1987). Oligonucleotide probes complementary to variable regions of ribosomal RNA discriminate between Mycoplasma species. J. Gen. Microbiol. 133:1969-1974.

Guadet, J., Julien, J., Lafay, J. F., Brygoo, Y. (1989). Phylogeney of some Fusarium species, as determined by large-subunit rRNA sequence comparison. Mol.Biol.Evol. 6:227-242. 
Gueho, E., Kurtzman, C.P., Peterson, S.W. (1989). Evolutionary affinities of heterobasidiomycetous yeasts estimated from $18 \mathrm{~S}$ and $25 \mathrm{~S}$ ribosomal RNA sequence divergence. Syst. Appl. Microbiol. 13:230-236.

Hallegraeff, G., Bolch, C.J. (1991). Transport of toxic dinoflagellate cysts via ship's ballast water. Mar. Poll. Bull. 22: 27-30.

Hallegraeff, G., Bolch, C.J., Blackburn, S.I., Oshima, Y. (1991). Species of the toxigenic dinoflagellate genus Alexandrium in southeastern Australian waters. Botanica Marina 34: 575-587.

Hallegraeff, G. M., and Bolch, C.J. (1992). Transport of toxic dinoflagellate cysts via ship's ballast water: implications for plankton biogeography and aquaculture. J. Plankton Res. 14:1067-1084.

Hayhome, B.A., Anderson, D.M., Kulis, D.M., Whitten, D.J. (1989). Variation among congeneric dinoflagellates from the northeastern United States and Canada I. Enzyme electrophoresis. Mar. Biol. 101: 427 - 435.

Lenaers, G.,Nielsen, H., Engberg, J., Herzog, M. (1988). The secondary structure of large-subunit rRNA divergent domains, a marker for protist evolution. BioSys. 21: 215 - 222.

Lenaers, G., Marteaux, L., Michot, B., Herzog, M. (1989). Dinoflagellates in evolution. A molecular phylogenetic analysis of large subunit ribosomal RNA. J.Mol. Evol. 29: 40 - 51.

Lenaers, G., Scholin, C. A., Bhaud, Y., Saint-Hilaire, D., Herzog, M. (1991). A molecular phylogeny of dinoflagellate protists (Pyrrhophyta) inferred from the sequence of the 24S rRNA divergent domains D1 and D8. J. Mol. Evolu. 32:53-63.

Maranda, L., Anderson, D.M., Shimizu, Y. (1985). Comparison of toxicity between populations of Gonyaulax tamarensis of eastern North American waters. Estuarine, Coastal and Shelf Science. 21: 401-410.

Mitchot, B., Hassouna, N., Bachellerie, J.P. (1984). Secondary structure of mouse 28S rRNA and general model for the folding of the large RNA in eukaryotes. Nuc.Acids Res. 12::4259-4279. 
Mitchot, B., Bachellerie, J.P. (1987). Comparisons of large subunit rRNAs reveal some eukaryote-specific elements of secondary structure. Biochimie 69:11-23.

McCutchan, T. F., de la Cruz, V. F. , Lal, A. A., Gunderson, J. H., Elwood, H. J., Sogin, M.L. (1988). Primary sequences of two small subunit ribosomal RNA genes from Plasmodium falciparum. Molec. Biochem. Parasitol. 28:63-68.

Olsen, G. J., Lane, D. J., Giovannoni, S. J., Pace, N.R. \& Stahl, D.A. 1986. Microbial evolution: a ribosomal RNA approach. Annu. Rev. Microbiol. 40:337-65.

Peterson, S. W., Kurtzman, C. P. (1991). Ribosomal RNA sequence divergence among sibling yeast species. Syst. Appl. Microbiol. 14:124-129.

Prakash, A., Medcof, J. C., Tennant, A.D. (1971). Paralytic shellfish poisoning in eastern Canada. Fisheries Research Board of Canada. Bulletin 177. 87 pp.

Qu, L.-H., M. Nicoloso, and J.-P. Bachellerie. 1988. Phylogenetic calibration of the 5 terminal domain of large rRNA acheived by determining twenty eukaryotic sequences. J. Mol. Evol. 28:113-124.

Qualye, D. B. (1969). Paralytic shellfish poisoning in British Columbia. Fisheries Research Board of Canada. Bulletin 168. 68 pp.

Raue', H.A., Klootwijk, J., Musters W. (1988). Evolutionary conservation of structure and function of high molecular weight ribosomal RNA. Prog. Biophys.molec. Biol. 51: 77 - 129.

Rowan, R., Powers, D. A. (1991). A molecular genetic classification of zooxanthellae and the evolution of animal-algal symbioses. Science. 251: 1348-1351.

Sako, Y., Kim, C.H., Ninomiya, H., Adachi, M., Ishida, Y. (1990). Isozyme and cross analysis of mating populations in the Alexandrium catenella/tamarense species complex. In: Graneli, E., Sundstrom, B., Edler, L., Anderson, D.M. (eds) Toxic Marine Phytoplankton. Elsevier, New York, pp. 320-323. 
Sako, Y. (1992). Molecular definition and detection of toxic-harmful phytoplankton species. In: Smayda, T.J., Shimizu, Y. (eds.) Fifith international conference on toxic marine phytoplankton. Elsevier, New York (in press).

Sako, Y., Adachi, M., Ishida, Y. (1992). Preparation and characterization of monoclonal antibodies to Alexandrium species. In: Smayda, T.J., Shimizu, Y. (eds.) Fifith international conference on toxic marine phytoplankton. Elsevier, New York (in press).

Smayda, T.J. (1990). Novel and nuisance phytoplankton blooms in the sea: Evidence for a global epidemic. In: Graneli, E., Sundstrom, B., Edler, L., Anderson, D.M. (eds) Toxic Marine Phytoplankton. Elsevier, New York, pp. 29-40.

Sogin, M.L., Elwood, H.J., Gunderson, J.H. (1986). Evolutionary diversity of eukaryotic small-subunit rRNA genes. Proc. Nat. Acad. Sci. U.S.A. $83: 1383-7$.

Sogin, M.L., Gunderson, J.H. (1987). Structural diversity of eukaryotic small subunit ribosomal RNAs: evolutionary implications. Endocytobiology III. Ann. N.Y. Acad. Sci. 503:125-39.

Stahl, D.A., Flesher, B., Mansfield, H. R., Montgomery, L. (1988). Use of phylogenetically based hybridization probes for studies of ruminal microbial ecology. Appl. Environ. Microbiol. 54:10791084.

Steidinger, K. A., Baden, D. G. (1984). Toxic marine dinoflagellates. In: Spector, D. L. (ed.). Dinoflagellates. Academic Press. pp. 201-261.

Steidinger, K.A. (1990). Species of the tamarensis/catenella group of Gonyaulax and the fucoxanthin derivative-containing Gymnodiniods. In: Graneli, E., Sundstrom, B., Edler, L., Anderson, D.M. (eds.) Toxic Marine Phytoplankton. Elsevier, New York, pp. 11-16 
Steidinger, K. A., and Moestrup, Ø. (1990). The taxonomy of Gonyaulax, Pyrodinium, Alexandrium, Gessnerium, Protogonyaulax and Goniodoma. In: Graneli, E., Sundstrom, B., Edler, L., Anderson, D.M. (eds) Toxic Marine Phytoplankton. Elsevier, New York, pp. 522-523.

Taylor, F. J. R. (1984). Toxic dinoflagellates: taxonomic and biogeographic aspects with emphasis on Protogonyaulax. In: Ragelis, E.P. (ed.) Seafood Toxins. Amer. Chem. Soc. Symp. Series No. 262, Washington, D.C. pp. 77-97.

Taylor, F. J. R. (1985). The taxonomy and relationships of red tide dinoflagellates. In : Anderson, D.M., White, A.W., Baden, D.G. (eds.) Toxic Dinoflagellates. Elsevier, New York, pp. 11-26.

Zarda, B., Amann, R., Wallner, G., Schleifer, K.-H. (1991). Identification of single bacterial cells using digoxigeninlabelled, rRNA-targeted oligonucleotides. J. Gen. Microbiol. 37:2823-2830. 
14 


\section{Chapter 1}

\section{Two Distinct Small-Subunit rRNA Genes in the North American Toxic Dinoflagellate Alexandrium fundyense (Dinophyceae) 1}

Christopher A. Scholin, Donald M. Anderson

Biology Department, Woods Hole Oceanographic Institution,

Woods Hole, Massachusetts 02543

and,

Mitchell L. Sogin

Marine Biological Laboratory, MBL St.,Woods Hole, Massachusetts O2543

1 submitted to the Journal of Phycology

[received:9 March 1992; accepted 8 May, 1992 (pending revisions)]

Running Title: rRNA Genes in Alexandrium fundyense 


\section{ABSTRACT}

Two distinct small-subunit rRNA genes, termed the "A gene" and "B gene," were detected in a clonal isolate of the toxic dinoflagellate, Alexandrium fundyense (Halim) Balech. The two sequences, which occur in roughly a 1:1 ratio in PCR-amplified material, differ at approximately 40 positions scattered throughout the length of the molecule. Transcripts of the B sequence were not detected in total RNA extracts from nutrient-replete and ammoniumstarved (sexually-induced) cultures or nutrient-replete log-phase cultures harvested at $2 \mathrm{~h}$ intervals over a complete circadian cycle. Many of the position changes in the B gene deviate from universallyand eukaryotic-conserved small-subunit rRNA sequences. In contrast, the A gene is expressed under all culture conditions tested and does not violate any conserved sequence positions. Thus, the B sequence is not represented by stable transcripts, and is probably a pseudogene. The B gene may serve as a useful marker for fine-scale population and taxonomic analyses of some Alexandrium species.

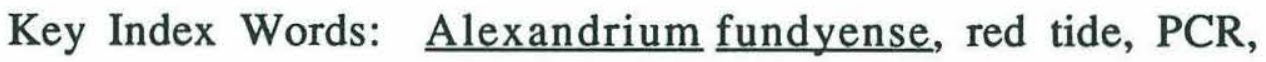
pseudogene, Pyrrophyta, small-subunit rRNA. 


\section{INTRODUCTION}

Small-subunit ribosomal RNA (SsrRNA) sequences are widely accepted for evaluating the evolutionary histories of organisms (Olsen et al. 1986, Sogin et al. 1986a, b, Field et al. 1988). These molecules have also been used as species- and even strain-specific markers and consequently appear to have potential in addressing both population ecology and fine-scale taxonomic questions (e.g., Gobel et al. 1987, McCutchan et al. 1988, Stahl et al. 1988, Amann et al. 1990, Distell et al. 1991). While assessing the utility of nuclear SsrRNA gene sequences (SsrDNAs) to delineate populations of closely-related toxic dinoflagellates, we discovered significant sequence variation between SsrDNAs from a clonal Alexandrium fundyense (Halim) Balech culture. This variation may provide a useful tool for descriminating between closely-related species or strains of Alexandrium.

Toxic dinoflagellates of the genus Alexandrium are responsible for paralytic shellfish poisoning (PSP; "red tides") along the northeastern coasts of the United States and Canada, as well as other temperate coastal waters throughout the world. These organisms pose an important problem in population biology and taxonomy, as well as a serious economic and public health concern (Anderson 1989). An alarming trend in recent years has been the apparent natural and human-assisted dispersal of toxic Alexandrium to regions of the world previously free of their presence (Anderson 1989, Hallegraeff and Bolch 1991, 1992). However, techniques to 
unambiguously distinguish between populations of these organisms are presently insuffcient to test specific dispersal theories.

Alexandrium species are also the subject of an ongoing taxonomic controversy, and only recently has an international agreement been reached on the appropriate genus designation (Steidinger 1990, Steidinger and Moestrup 1990). Although the confusion over genus names appears to be over, there continue to be concerns about species assignments (Taylor 1985). For example, in a recent revision of Alexandrium taxonomy, the closely-related toxic

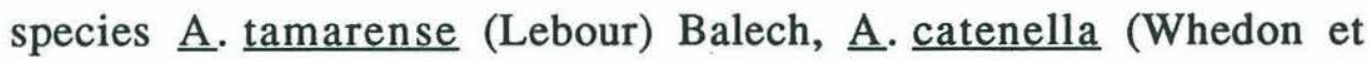
Kofoid) Balech and $\underline{A}$. fundyense were distinguished on the basis of fine-scale morphological features (Balech 1985, Balech and Tangen 1985). Other authorities, however, believe these organisms (commonly referred to as the "tamarensis group" or "tamarensis/ catenella complex") represent a single species complex comprised of numerous biochemically-distinct varieties (Taylor 1985, Cembella and Taylor 1986, Cembella et al. 1987).

The disagreement over fine-scale taxonomic indicators inspired a search for additional biochemical and genetic markers that would be useful in clarifying Alexandrium systematics. Detailed toxin composition and enzyme electrophoretic studies, in conjunction with traditional, morphologically-based taxonomic analyses, have all been applied to assess the genetic similarity of Alexandrium isolates (Maranda et al. 1985, Cembella and Taylor 1986, Cembella et al. 1987, Hayhome et al. 1989). Collectively, these markers represent 
complex character states that are dependent on the coordinated expression of multiple genes; equitable comparisons of such characters require fastidious culturing, harvesting, preparative and analytical procedures. Despite such efforts, population and taxonomic boundaries within and between Alexandrium species have remained coarse. Thus at present, genetic markers specific for many strains of Alexandrium are lacking and there is disagreement over the relative importance of morphologically-based taxonomic criteria. This, in turn, has complicated efforts to understand the population dynamics and potential dispersal of these toxic organisms.

In an attempt to identify molecular markers for species or strains of Alexandrium, we undertook the sequence analysis of nuclear SsrDNA. This analysis is not dependent on the physiological state of the organism nor the concomitant expression of other genes, and therefore has many advantages over morphological and biochemical studies conducted previously. Surprisingly, SsrDNAs from a clonal, toxic, eastern North American $\underline{\text { A. fundyense (strain }}$ GtCA29, formerly Protogonyaulax tamarensis Taylor; Hayhome et al. 1989) amplified using the polymerase chain reaction (PCR; Saiki et al., 1988) contained two distinct sequences. In contrast, the SsrDNA sequence recently reported for a nontoxic, western European $\underline{\mathrm{A}}$. tamarense (Destombe et al. 1992) includes only a single class of genes. Here, we describe the characterization of the two genes in $\underline{A}$. fundyense, attempts to determine if both are expressed, their relationship to other known, functional SsrRNAs, and the implications of this finding with regards to the use of rDNA sequences as genetic 
and taxonomic markers for Alexandrium species. The use of these genes in biogeographic studies will be presented elsewhere.

\section{MATERIALS and METHODS}

A culture of Alexandrium fundyense strain GtCA29, established from a cyst isolated from Gulf of Maine sediments $\sim 32 \mathrm{Km}$ east of Portsmouth, New Hampshire, was rendered clonal by isolation of a single swimming cell. This culture was maintained as asexually reproducing or "sexually induced" in $f / 2$ or ammonia-encystment medium, respectively, as described by Anderson et al. (1984).

RNA isolation. All stock solutions for RNA isolation were prepared with DEPC-treated (Sigma) $\mathrm{ddH}_{2} \mathrm{O}$ using baked glassware and disposable, pre-sterilized glass or plasticware. Where appropriate, solutions were filtered and autoclaved.

Approximately $2 \mathrm{~L}$ of a mid-late $\log$ culture $(2-5,000$ cells $\mathrm{mL}^{-1}$ ) was concentrated on a $20 \mu \mathrm{m}$ Nitex mesh, backwashed with sterile sea water into a disposable $50 \mathrm{~mL}$ centrifuge tube and briefly spun to pellet the cells. The supernatant was removed by aspiration. The cells were resuspended in $\sim 10 \mathrm{~mL}$ of sterile sea water, transferred into a disposable $15 \mathrm{~mL}$ centrifuge tube and pelleted again. Supernatant was removed as before, and the tube was immediately immersed in liquid nitrogen where it was stored until further processing. 
The frozen cell pellet was allowed to thaw at room temperature briefly, resuspend in $5.5-6.0 \mathrm{~mL}$ of freshly prepared guanidine isothiocyanate lysis buffer ( $5 \mathrm{M}$ guanidine isothiocyanate, $25 \mathrm{mM}$ NaCit pH 7.0, 25 mM EDTA, 25 mM EGTA, 0.5\% sarkosyl, 2.0\% mercaptoethanol), placed in a nitrogen bomb (Parr Instrument Co.) that was then pressurized to $\sim 2,000 \mathrm{psi}$ for $\sim 5 \mathrm{~min}$. and released to atmospheric pressure. The resulting lysate was collected into a fresh $15 \mathrm{~mL}$ disposable centrifuge tube and extracted three times with phenol:chloroform (1:1; phenol equilibrated with $10 \mathrm{mM}$ Tris $\mathrm{pH} 8.0$ and $0.1 \%$ mercaptoethanol), and once with chloroform. Following the final extraction, the aqueous phase was transferred to baked, Corex centrifuge tubes, and the nucleic acids were precipitated by the addition of 2.5 volumes of $100 \% \mathrm{EtOH}, 1 / 20$ volume of $4 \mathrm{M} \mathrm{NH} 4 \mathrm{OAc}$ ( $\mathrm{pH}$ 5.0) and chilling at $-70{ }^{\circ} \mathrm{C}$ for $>1 \mathrm{~h}$. Precipitates were collected by centrifugation at $\sim 4^{\circ} \mathrm{C}$ for $20 \mathrm{~min}$ at $10,000 \mathrm{rpm}$ in a Beckman model J2-21 centrifuge fitted with a JA-20 rotor. The supernatants were discarded, the pellets were briefly drained and then resuspended in $2-4 \mathrm{~mL}$ of DEPC-treated $\mathrm{ddH}_{2} \mathrm{O}$. Total RNA was precipitated by adding $\mathrm{LiCl}_{2}$ to a final concentration of $2 \mathrm{M}$ (Ausubel et al., 1987) and leaving the samples on ice overnight. The precipitated RNA was collected as above. The pellets were carefully rinsed with chilled $2 \mathrm{M} \mathrm{LiCl}_{2}$, resuspended in a total volume of $\sim 2 \mathrm{~mL}$ of DEPC-treated $\mathrm{ddH}_{2} \mathrm{O}$, and precipitated once more using $\mathrm{LiCl}_{2}$ as above. Precipitates were collected again by centrifugation, and the RNA pellet was resuspended in $1 \mathrm{~mL}$ of DEPC-treated $\mathrm{ddH}_{2} \mathrm{O}$. An aliquot of this was used for quantification (absorbence at $260 \mathrm{~nm}$ ), and the remainder precipitated immediately (Ausubel et al., 1987). 
Precipitated RNA samples were stored at $-70^{\circ} \mathrm{C}$ until needed for sequencing. For sequencing, an aliquot of the RNA precipitate was transferred to a microcentrifuge tube, collected by centrifugation, and resuspended in DEPC-treated $\mathrm{ddH}_{2} \mathrm{O}$ to a final concentration of $\sim 1 \mathrm{mg} \mathrm{mL}-1$.

DNA extraction. Approximately $50 \mathrm{~mL}$ of a mid-log culture $\left(\sim 2,000-3,000\right.$ cells $\left.\mathrm{mL}^{-1}\right)$ was briefly centrifuged to pellet the cells. The supernatant was discarded. The cell pellet was resuspended in $2.0 \mathrm{~mL}$ of STE $(10 \mathrm{mM} \mathrm{NaCl}, 10 \mathrm{mM}$ Tris HCL pH $7.5,1 \mathrm{mM}$ EDTA pH 8.0) and disrupted in a French pressure cell. SDS was added to a final concentration of $1 \%$, and the resulting solution was extracted twice with phenol equilibrated with STE, once with STE-saturated phenol:chloroform:isoamyl alcohol (PCI; 24:24:1) and once with chloroform:isoamyl alcohol (CI; 24:1). DNA was precipitated by the addition of two volumes of EtOH and $1 / 10$ volume of $3 \mathrm{M} \mathrm{NaOAc}$, followed by incubation at $-20^{\circ} \mathrm{C}$ for $>2 \mathrm{~h}$. The precipitate was collected by centrifugation, rinsed with $80 \% \mathrm{EtOH}$, spun again, and resuspended in $200 \mu \mathrm{L}$ of LT ( $10 \mathrm{mM}$ Tris HCL pH 7.5, $10 \mathrm{mM} \mathrm{NaCL}$, $0.5 \mathrm{mM}$ EDTA $\mathrm{pH}$ 8.0). The concentration of the DNA was determined by diluting an aliquot of the resuspended material and reading its absorbence at $260 \mathrm{~nm}$ (Ausubel et al. 1987).

PCR amplification of SsrDNA. Universal eukaryotic primers containing polylinker restriction sites (Medlin et al. 1988) were used to amplify full-length SsrDNAs (Sogin 1990) with 30 cycles of a Perkin-Elmer Cetus DNA Thermal Cycler set as follows: $2 \mathrm{~min}$ 
denaturation at $94^{\circ} \mathrm{C} ; 2$ min ramp to $37^{\circ} \mathrm{C} ; 2$ min primer annealing at $37^{\circ} \mathrm{C} ; 3 \mathrm{~min}$ ramp to $72^{\circ} \mathrm{C}$; and $6 \mathrm{~min}$ extension at $72^{\circ} \mathrm{C}$. Three replicate $100 \mu \mathrm{L}$ amplification reactions were conducted in parallel using $1 \mathrm{ng}, 10 \mathrm{ng}$ and $100 \mathrm{ng}$, respectively, of $\underline{\mathrm{A}}$. $\underline{\text { fundyense }}$ genomic DNA. PCR products were subjected to agarose gel electrophoresis; amplifications using 10ng and 100ng of genomic DNA yielded the best product. Products from each replicate amplification were purified by extracting once with an equal volume of STE P:C:I and once with C:I. Afterwards, they were concentrated by EtOH precipitation and resuspended in $10 \mu \mathrm{L} \mathrm{LT}$. The concentration of SsrDNAs in each replicate was determined by diluting an aliquot of the material and reading its absorbence at $260 \mathrm{~nm}$.

Cloning of SsrDNA. Purified, concentrated products from two PCR amplification reactions were mixed, digested with Bam HI and Sal I (New England Biolabs), and ligated into Bam HI/Sal I-cut replicative forms of M13 mp18 and M13 mp19 bacteriophage (Messing, 1983) as described by Medlin et al. (1988). Individual clones were subsequently grown and screened by agarose gel electrophoresis for the presence of a correctly-sized insert; $22 \mathrm{mp} 18$ (coding strand) and $24 \mathrm{mp} 19$ (non-coding strand) positive (insertcontaining) clones were identified.

Preparation of M13 DNA for sequencing. The population of PCR

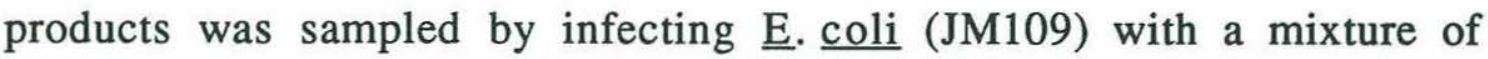
all positive mp18 or mp19 phage. Single stranded, "pooled" mp18 and mp19 templates (ie. mixtures of all mp18 or mp19 
recombinants, respectively) were isolated as described by Messing (1983). For analysis of individual clones, templates were prepared separately from four clones in $\mathrm{mp} 18$ and four clones in mp19.

Sequencing of SsrDNA. All sequencing reactions were carried out using modified T7 polymerase (Pharmacia or USB sequenase $\mathrm{V}$ 2.0) with dATP $\left[\alpha^{35}\right.$ S ] label (Amersham) and dideoxy chain termination (Sanger and Coulson 1975). Coding and non-coding strands of the amplified, cloned SsrDNA products were sequenced in their entirety using a series of primers complementary to conserved sites in the molecule (Elwood et al. 1985).

Sequencing of SsrRNA. Primers complementary to conserved regions at Dictyostelium discoideum nucleotide positions 1139-1125 and 906-892 (Sogin and Gunderson 1987) were end-labelled with ATP $\left[\gamma^{35}\right.$ S] (Amersham; Ausubel et al. 1987) and used to sequence (Lenaers et al. 1991) a portion of the SsrRNA which encompasses multiple nucleotide differences in the A and B genes.

\section{RESULTS}

PCR amplification of SsrDNAs from $\underline{\mathrm{A}}$. $\underline{\text { fundyense }}$ (GtCA29) yielded a product of approximately 1800 nucleotides. Individual SsrDNA clones were combined, and the resultant "pool" was sequenced, permitting assessment of genomic heterogeneity and potential errors introduced during early rounds of the PCR reaction (Medlin et al. 1988). This analysis revealed both sequence 
ambiguities and length heterogeneities in the cloned SsrDNA PCR products. The length differences obscured the pooled clone sequencing ladders, making it impossible to resolve portions of the sequence. Therefore, 8 individual SsrDNA clones (4 each of the coding and non-coding strands) were sequenced separately in order to characterize regions of heterogeneity. Sequences obtained from pooled and individual clones revealed the existence of at least 40 differences in the cloned SsrDNAs. Two distinct classes of genes were identified, and termed the "A gene"(1802 base pairs) and "B gene" (1800 base pairs). The sequences differ by 13 transitions, 24 transversions, 2 single base pair deletions and 1 single base pair insertion; 32 of these differences were unambiguously identified by the analysis of individual SsrDNA clones (positions 172-1300). The remaining 8 heterogeneities occurred in regions that were not sequenced with individual clones (Fig. 1).

The "A gene" and "B gene" exist as a "family" of sequences in the PCR products, each with its own "intrafamily" variations. However, sequences within either the "A gene family" or "B gene family" are nearly identical ( $>99 \%$ similar). For simpilicity, the terms "A gene" (or "A sequence") and "B gene" (or "B sequence") are used throughout the remainder of this article as a designation of the "A gene family" "B gene family", respectively. "A gene clones" included molecules that differ at 6 positions (4 transitions, 2 transversion); "B gene clones" included molecules that also differ at 6 positions (4 transitions, 2 transversion). The substitutions within the $\mathrm{A}$ and $\mathrm{B}$ 
Fig. 1. Nucleotide sequences of the A and B SsrDNAs from $\underline{A}$. fundyense. The A sequence is presented in its entirety; substitutions in the B sequence are indicated below each line, with superscripts to indicate whether that position in the sequence is evolutionarily variable (0), or conserved among: dinoflagellates (1); dinoflagellates, apicomplexans and ciliates (2); eukaryotes (3); or, eukaryotes and prokaryotes (universally-conserved; 4). "*" denotes single-base deletions in the B gene. Two alignment gaps ("-") in the A gene are necessary to accomodate the B gene's single-base insertion (between A gene nucleotides 1114 and 1115 ) and corresponding superscript. Dashed lines above the sequence indicate portions of the molecule sequenced with individual SsrDNA clones. Ambiguities identified in these regions are designated as follows: $\mathrm{R}=\mathrm{G}$ or $\mathrm{A} ; \mathrm{Y}=\mathrm{C}$ or $\mathrm{T} ; \mathrm{K}=\mathrm{G}$ or $\mathrm{T} ; \mathrm{M}=\mathrm{C}$ or $\mathrm{A}$ (IUPAC ambiguity codes). 
1
CAACCTGGTTGATCCTGCCAGTAGTCATATGCTTGTCTCAAAGATTAAGCCATGCATGTCTTAGTATAAGCTTCAATTTTGTGAAACTGCAAATGGCTCATTAAAACAGTCACAAYGCATTTGGCGATCAATTCTAAATGGATATCTGTGGRAATTCTAT

161

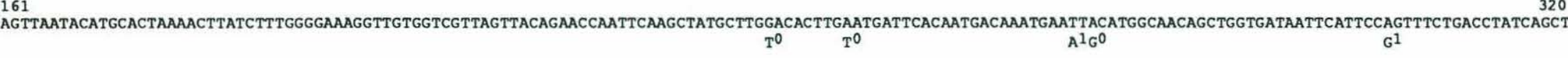
321 TTCGAGGTAAGGTATTGGCTTACCGTGGCAATGACAGGTGACGGAGGATTAGGGTTTGATTCCGGAGAGGGAGCTTGAGAAATGGCTA $G^{2}$ 480

481

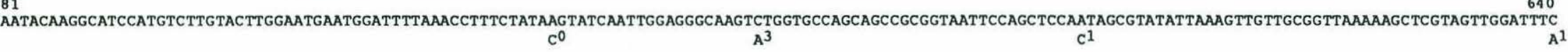
641 TGCTGAGGATGGCTGGTCCGCCCTCTGGGTGAGTATTTGGCACAGCCTGAGCATTTATCTTGAAAGTACAACTGCACTTGACTGTGTGGTGTGTTATTGAGACATTTACTTTGAGGAAATCAGAGTGTTTCAAGCAGGTGTTTGGCCTTGAAT

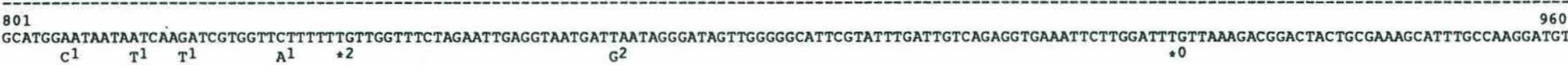

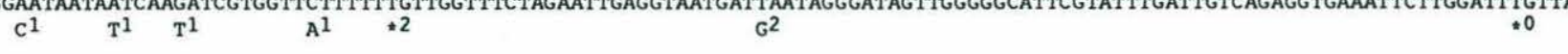
961
TTTCATTGATCAAGAACGAAAGTTAAGGGATCGAAGACGATCAGATACCGTCCTAGTCTTAACCATAAACCATGCCAACTAGAGATTGGAGGTTGTTACTTGTATGACTTTTTCAGCACCCTATGCGAAATCAAAGTGTTTGGGTTCCGGGGGG--AGTA
$\mathrm{T}^{4}$

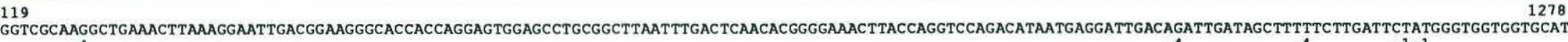
$\mathrm{G}^{4}$

$G^{4}$

$G^{4} \quad A^{1} C$

1279

143

1596 (1) GATGCCCTTAGATGTTCTGGGCTGCACGYGCGCTACACTGATGTGTTCAACGAGTTKTCAACCTTGCCTGGAAAGGTTTGGTAATTCTTGAACAGGCATCGTGATGGGGATTGTTTATTGCAATTATTAACCTTCAACGAGGAATTCCTAGTAAGCTTGA $\mathrm{K}^{0}$

1599 GTCATCAGCTTGTGCT

1759
GTCGTAACAAGGTTTCTGTAGGTGAACCTGCAGAAGGATCAAGC 
genes have not been reported in Fig. 1 since they are represented by only a single SsrDNA clone and are not corroborated by other sequence data (cf., Scholin, 1992).

In order to determine if both genes encode stable transcripts, total RNA was isolated from mid-log cultures that were grown under both nutrient replete (asexually reproducing) and ammonium starved ("sexually induced;" Anderson et al. 1984) conditions. RNA was also extracted from a nutrient replete, log-phase culture at $2 \mathrm{~h}$ intervals over a complete circadian cycle. Reverse transcriptase (RTase) sequencing of a portion of the SsrRNAs known to contain multiple differences between the two genes revealed that transcripts of the A gene were clearly present in all samples. In contrast, there is no evidence for the presence of B gene transcripts (Fig. 2).

Figure 2 illustrates the identification of SsrRNAs by RTase sequencing. If transcripts of the $A$ and $B$ genes were both present in cellular RNA, a G/U ambiguity would appear at position 974 and the single base deletion at position 920 would cause a single base shift for some fraction of the sequencing ladder above the position where it occurs in the autoradiograph. By both criteria, there is no evidence for B gene transcripts; over-exposing the autoradiograph also failed to reveal any trace amounts of B gene SsrRNAs (data not shown).

Further analysis of the $\mathrm{A}$ and $\mathrm{B}$ sequences was undertaken by comparing them to 131 eukaryotic and 13 prokaryotic SsrRNAs (Neefs et al. 1990): Of the 32 differences that were identified by 
sequencing individual $\mathrm{A}$ and $\mathrm{B}$ gene clones, the majority were at positions that are not variable in functional SsrRNAs: 7 occurred at universally-conserved sites, 3 occurred at positions conserved among all eukaryotes, 4 occurred at sites conserved among dinoflagellates, apicomplexans, and ciliates, 11 occurred at nucleotides conserved among several dinoflagellates (Amphidinium caterae Hulburt, Crypthecodinium cohnii (Seligo) Chatton, Prorocentrum micans Ehrenberg), and 7 differences occurred at evolutionarily-variable sites. Discrepancies between the A and B genes that violate evolutionarily-conserved sequence positions map exclusively to the B gene (Fig. 1). ${ }^{1}$

\section{DISCUSSION}

Two distinct SsrRNA genes, named the "A gene" and "B gene" (Fig. 1), have been identified by sequencing PCR-amplified SsrDNAs from a clonal culture of $\underline{\mathrm{A}}$. fundyense. These two sequences are 97\% identical. In addition, the $\mathrm{A}$ and $\mathrm{B}$ genes were estimated to be present in an approximately $1: 1$ ratio in the PCR-amplified, cloned SsrDNAs.

We initially considered the possibility that $\underline{A}$. fundyense (GtCA29) was not a true clone, but in fact was a mixture of two

\footnotetext{
1 two of the individually-sequenced $\mathrm{A}$ gene clones each contain one transition at different positions in the molecule, and both of these substitutions do deviate from universallyconserved positions. Because these substitutions are represented by single clones and not substantiated by other sequence data, we suspect they are PCR or cloning artifacts (cf. Scholin, 1992)
} 
Fig. 2. Sequencing gel of SsrRNAs from total RNA extracts of A. fundyense (GtCA29), with a comparison to known A and B SsrDNA gene sequences. Numbers indicate nucleotide positions in the A gene (Fig. 1). The complement of specific nucleotide termination reactions are indicated above each lane. "N" represents no ddNTP addition. Arrows indicate differences between the A and $B$ genes and the identity of that position in the expressed SsrRNAs. "** indicates a single base deletion within the B gene. The singlebase deletion (position 920) occurrs at an evolutionarily-variable position. The G/T transversion (position 974) occurrs at a universally-conserved position (Fig. 1). 


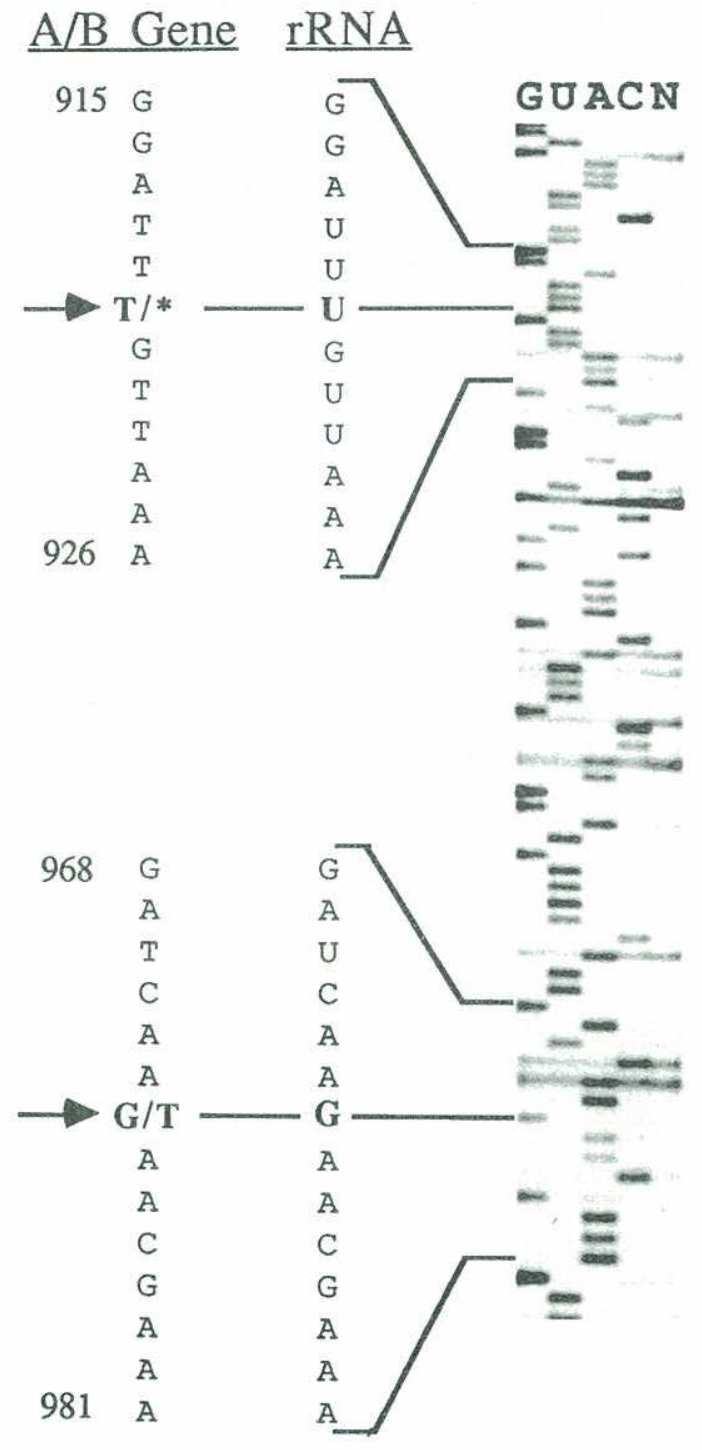


distinct Alexandrium isolates. If this were the case, the culture would contain both A and B SsrDNAs transcripts. However, it contained only A gene transcripts (Fig. 2). Thus, it was highly unlikely that the two, distinct SsrDNAs cloned from $\underline{A}$. $\underline{\text { fundyense }}$ originated from a mixed culture. Two lines of reasoning then led us to speculate that the $\mathrm{B}$ gene might be expressed under more specialized circumstances. First, the apicomplexan Plasmodium berghei is known to carry two SsrRNA genes that are differentially expressed over the course of its life cycle (Gunderson et al. 1987), and dinoflagellate SsrRNAs do share a unique, common evolutionary history with apicomplexans (Gajadhar et al. 1991). We suspected that an analogous switch in gene expression might occur in $\underline{\mathrm{A}}$. fundyense as it progressed through a developmental cycle, perhaps associated with the induction of sexuality. Second, since dinoflagellates are known to exhibit strong circadian rhythms in total RNA synthesis and translational regulation of a gene involved with luminescence (Walz et al. 1983, Morse et al. 1989), we reasoned that differential expression of the $\mathrm{A}$ and $\mathrm{B}$ genes might occur during the light and dark phases of growth. However, B gene transcripts do not appear in total cellular RNA in response to sexual induction (nitrogen starvation; Anderson et al. 1984) or over the course of a circadian cycle (data not shown). Consequently, it appears that the B gene is either transcriptionally-inactive and/or encodes an unstable product.

The probable nature of the $\mathrm{B}$ gene became apparent when it was compared to other SsrRNA sequences. Nucleotide substitutions in the $\mathrm{B}$ gene, but not the A gene, violate many highly-conserved 
sequences (Fig. 1). ${ }^{2}$ The B gene's deviations from evolutionarilyconserved motifs are especially significant because these sequence elements are considered essential to the basic core structure of a functional ribosome (Raue et al. 1988). The fact that the B sequence varies from these highly-conserved elements and that B gene transcripts are apparently rare or absent in RNA extracts leads us to conclude that the B sequence is a pseudogene.

Two lines of evidence suggest that the $\mathrm{A}$ and $\mathrm{B}$ genes are present in approximately equal proportions in the PCR products. First, sequence ambiguities observed in the pooled clone sequencing ladders always appeared with nearly equal band intensities, indicating that templates harboring alternative nucleotides are equally abundant. Those ambiguities characterized by sequencing single SsrDNA clones revealed that one of two nucleotide alternatives was indeed contiguous with either the A or B sequence. Second, of the 8 individual clones sequenced, 5 are $\mathrm{A}$ genes and 3 are $\mathrm{B}$ genes, suggesting that the proportions of cloned $\mathrm{A}$ and $\mathrm{B}$ sequences are roughly equivalent.

The B sequence cannot result from PCR artifact for several reasons. First, if errors were being introduced randomly both genes would be expected to show multiple deviations from evolutionarilyconserved positions, yet the B gene alone displays this type of variance. ${ }^{3}$ Second, both sequences have been reproducibly amplified

2,3 cf. footnote 1 
and detected by either restriction fragment polymorphism analysis (RFLP; Scholin and Anderson 1992) or direct sequencing of the PCR products (data not shown). Thus, the A and B genes must be present in the extracted DNA from $\underline{A}$. fundyense. Furthermore, they consistently appear in a near 1:1 ratio (Scholin and Anderson 1992) as predicted from sequencing pooled and individual SsrDNA clones.

If the ratio of $\mathrm{A}$ and $\mathrm{B}$ genes in $\mathrm{PCR}$ products reflects their abundance in the extracted DNA, then the two genes may be present in near equal numbers within the $\underline{\mathrm{A}}$. fundyense genome. This, however, raises an interesting question: why are so many copies of an apparent pseudogene being maintained? One possibility is that the B gene is perpetuated simply as a result of its linkage to other, functional rRNA genes. Analyzing individual A and B gene rDNA cistrons along with their respective promoter regions would be useful in addressing this possibility. Viral or other insertional elements in close proximity to the B sequence should not be discounted as players in the B gene's transcriptional inactivity and/or maintenance (Jakubczak et al. 1992).

Despite the fact that we cannot fully explain the origin and apparent abundance of the B gene within $\underline{A}$. fundyense, it nonetheless holds promise as a biogeographic and taxonomic marker for this group of organisms. If the B gene is a pseudogene and is no longer under selective pressure, then it is likely to be evolving rapidly. These features should make the B gene a very sensitive marker for identifying and distinguishing between groups of 
morphologically-similar, but geographically-distinct, strains or species of Alexandrium. This supposition is supported by comparing the $\mathrm{A}$ and $\mathrm{B}$ genes to the SsrDNA sequence recently reported for a non-toxic, Western European A. tamarense (Destombe et al. 1992). The $\underline{\mathrm{A}}$. tamarense SsrDNA is approximately $98 \%$ identical to the $\underline{\mathrm{A}}$. fundyense A gene and lacks "B-like" homology. In addition, we have independently examined PCR-amplified SsrDNAs from the Western European A.tamarense using an RFLP-based assay and find no evidence for presence of the B gene (Scholin and Anderson 1992). Therefore, both actively-expressed SsrRNA genes and the B gene appear to be informative biogeographic and taxonomic characters of Alexandrium species.

The finding of two small-subunit rRNA genes in $\underline{A}$. fundyense underscores the risk associated with using a single clone of a multigene family as the representative sequence of an organism's genotype. Multiple clones must be pooled prior to sequencing, or individually sequenced, in order to assess the homogeneity of cloned products and reduce the possibility of obtaining artifactual data (Sogin 1990). In this regard, the extensive SsrRNA data base is a substantial resource that should be used in conjunction with sequencing methods that utilize either PCR-amplified SsrDNAs or their corresponding RNA transcripts.

We thank D.M. Kulis for his help in culturing $\underline{A}$. fundyense, and E.Ariztia-Carmona and C. Bibeau for their assistance in cloning and sequencing of the rDNAs. This work was supported by grants from 
the National Science Foundation No. OCE 8911226 (D.M.A), National

Institute of Health No. GM32964 (M.L.S.), and the Woods Hole

Oceanographic Institution Ocean Ventures Fund (C.A.S.). Contribution

No. ---- from the Woods Hole Oceanographic Institution.

\section{LITERATURE CITED}

Amann, R.I., Krumholz, L., Stahl, D.A. (1990). Fluorescentoligonucleotide probing of whole cells for determinative, phylogenetic, and environmental studies in microbiology. J. Bacteriol. 172:762-70.

Anderson, D.M. (1989). Toxic algal blooms and red tides: a global perspective. In Okaichi,T., Anderson, D.M. \& Nemoto,T. [Eds.] Red tides: Biology, Environmental Science and Toxicology. Elsevier, New York, pp. 11 - 20.

Anderson, D.M., Kulis, D.M., Binder, B.J. (1984). Sexuality and cyst formation in the dinoflagellate Gonyaulax tamarensis: cyst yield in batch cultures. J.Phycol. 20:418-25.

Ausubel, F.M., Brent, R., Kingston, R.E., Moore, D.D., Siedman, J.G., Smith, J.A., Struhl, K. (1987). Current Protocols in Molecular Biology. Wiley Interscience, New York, Vols. 1 and 2.

Balech, E. (1985). The genus Alexandrium or Gonyaulax of the tamarensis group. In: Anderson, D.M., White, A.W.\& Baden, D.G. [Eds.] Toxic Dinoflagellates. Elsevier, New York, pp. 33-8.

Balech, E, Tangen, K. (1985). Morphology and taxonomy of toxic species in the tarmarensis group (Dinophyceae): Alexandrium excavatum (Braarud) comb. nov. and Alexandrium ostenfeldii (Paulsen) comb. nov. Sarsia 70: 333-343.

Cembella, A.D., Sullivan, J.J., Boyer, G., Taylor, F.J.R., Andersen, R.J. (1987). Variation in paralytic shellfish toxin composition within the Protogonyaulax tamarensis/catenella species complex: red tide dinoflagellates. Biochem. Syst. Ecol. 15:171-86. 
Cembella, A.D., Taylor, F.J.R. (1986). Electrophoretic variability within the Protogonyaulax tamarensis/catenella species complex: pyridine linked dehydrogenases. Biochem. Syst. Ecol. 14:311-23.

Destombe, C., Cembella, A.D., Murphy, C.A., Ragan, M.A. 1992. Nucleotide sequence of the $18 \mathrm{~S}$ ribosomal RNA genes from the marine dinoflagellate Alexandrium tamarense (Gonyaulacales, Dinophyta). Phycologia 31: 121-4.

Distel, D.L., DeLong, E.F., Waterbury, J.B. (1991). Phylogenetic characterization and in situ localization of the bacterial symbiont of shipworms (Teredinidae: Bilvalvia) by using 16S rRNA sequence analysis and oligodeoxynucleotide probe hybridization. Appl. Environ. Microbiol. 57:2376-82.

Elwood, H.J., Olsen, G.J.,Sogin, M.L. (1985). The small subunit ribosomal RNA gene sequences from the hypotrichous ciliates Oxytricha nova and Strylonychia pustulata. J.Mol.Biol.Evol. 2:399-410.

Field, K.G., Olsen, G.J., Lane, D.J., Giovannoni, S.J., Ghiselin, M.T., Raff, E.C., Pace, N.R., R.A. Raff. (1988). Molecular phylogeny of the animal kingdom. Science 239:748-53.

Gajadhar, A.A., Marquart, W.C., Hall, R., Gunderson, J., AriztiaCarmona, E.V., Sogin, M.L. (1991). Ribosomal RNA sequences of

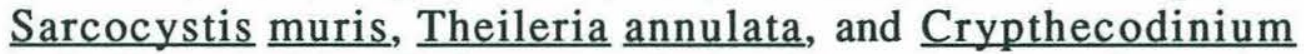
cohnii reveal evolutionary relationships among apicomplexans, dinoflagellates, and ciliates. Mol. Biochem. Parisitol. 45:14754.

Gobel, U.B., Geiser, A., Stanbridge, E.J. (1987). Oligonucleotide probes complementary to variable regions of ribosomal RNA discriminate between Mycoplasma species. J. Gen. Microbiol. 133:1969-74.

Gunderson, J.H., Sogin, M.L., Wollet, G., Hollingdale, M., de la Cruz, V.F., McCutchan, T.F. (1987). Structurally distinct, stagespecific ribosomes occur in Plasmodium. Science 238:933-7.

Hallegraeff, G., Bolch, C.J. (1991). Transport of toxic dinoflagellate cysts via ship's ballast water. Mar.Poll.Bull. 22: 27-30. 
Hallegraeff, G., Bolch, C.J. (1992). Transport of toxic dinoflagellate cysts via ship's ballast water: implications for plankton biogeography and aquaculture. J. Plankton Res. 14: 1067-1084.

Hayhome, B.A., Anderson, D.M., Kulis, D.M., Whitten, D.J. (1989). Variation among congeneric dinoflagellates from the northeastern United States and Canada. I. Enzyme electrophoresis. Mar. Biol. (Berl.) 101:427-35.

Jakubczak, J. L., Zenni, M. K., Woodruff, R. C., Eickbush, T. H. (1992). Turnover of R1 (type 1) and R2 (type 2) retrotransposable elements in the ribosomal DNA of Drosophila melanogaster. Genetics 131:12942 .

Lenaers, G., Scholin, C. A., Bhaud, Y., Saint-Hilaire, D., Herzog, M. (1991). A molecular phylogeny of dinoflagellate protists (Pyrrhophyta) inferred from the sequence of the 24S rRNA divergent domains D1 and D8. J.Mol.Evol. 32:53-63.

Maranda, L., Anderson, D.M., Shimizu, Y. (1985). Comparison of toxicity between populations of Gonyaulax tamarensis of eastern North American waters. Estuarine Coastal Shelf Sci. 21:401-10.

McCutchan, T.F., de la Cruz, V.F., Lal, A.A., Gunderson, J.H., Elwood, H.J., Sogin, M.L. (1988). Primary sequences of two small subunit ribosomal RNA genes from Plasmodium falciparum. Mol. Biochem. Parasitol. 28:63-8.

Medlin, L., Elwood, H.J., Stickel, S., Sogin, M.L. (1988). The characterization of enzymatically amplified eukaryotic 16S-like rRNA-coding regions. Gene 71:491-9.

Messing, J. (1983). New M13 vectors for cloning. Meth. Enzymol. 101:20 - 78 .

Morse, D., Milos, P.M., Roux, E., Hastings, J W. (1989). Circadian regulation of bioluminescence in Gonyaulax involves translational control. Proc. Nat. Acad. Sci. U.S.A. 86:172-6.

Neefs, J-M., Van de Peer, Y., Hendriks, L., De Wachter, R. (1990). Compilation of small-subunit ribosomal RNA sequences. Nucl. Acid. Res.(Suppl.) 18:2237-317. 
Olsen, G.J., Lane, D.J., Giovannoni, S.J., Pace, N.R., Stahl, D.A. (1986). Microbial evolution: a ribosomal RNA approach. Annu. Rev. Microbiol. 40:337-65.

Raue, H.A., Klootwijk, J., Musters, W. (1988). Evolutionary conservation of structure and function of high molecular weight ribosomal RNA. Proc. Biophys. Molec. Biol. 51:77-129.

Saiki, R.K., Gelfand, D.H., Stoffel, S., Scharf, S.J., Higuchi, R., Horn, G.T., Mullis, K.B., Erlich, H.A. (1988). Primer-directed enzymatic amplification of DNA with a thermostable DNA polymerase. Science 239:487-91.

Sanger, F, Coulson, A.R. (1975). A rapid method for determining sequences in DNA by primed synthesis with DNA polymerase. J. Mol. Biol. 94: 441-8.

Scholin, C.A. (1992). Analysis of toxic and non-toxic Alexandrium (Dinophyceae) species using ribosomal RNA gene sequences. Ph.D. Thesis. Massachusetts Institute of Technology/Woods Hole Oceanographic Institution. 251 pp.

Scholin, C.A., Anderson, D.M. (1992). Population analysis of toxic and nontoxic Alexandrium species using ribosomal RNA signature sequences. In: Smayda, T.J. \& Shimizu, Y. [Eds.] Fifith International Conference on Toxic Marine Phytoplankton. Elsevier, New York. (in press).

Sogin, M.L. (1990). Amplification of ribosomal RNA genes for molecular evolution studies. In: Innis, M.A., Gelfand, D.H., Sninsky, J.J. \& White, T.J. [Eds.] PCR Protocols: A Guide to Methods and Applications. Academic Press, New York, pp 30714.

Sogin, M.L., Gunderson, J.H. (1987). Structural diversity of eukaryotic small subunit ribosomal RNAs: evolutionary implications. Endocytobiology III. Ann. N.Y. Acad. Sci. 503:125-39.

Sogin, M.L., Elwood, H.J., Gunderson, J.H. (1986 a). Evolutionary diversity of eukaryotic small-subunit rRNA genes. Proc. Nat. Acad. Sci. U.S.A. $83: 1383-7$. 
Sogin, M.L., Ingold, A., Karlok, M., Nielsen, H., Engberg, J. (1986b). Phylogenetic evidence for the acquisition of ribosomal RNA introns subsequent to the divergence of some of the major Tetrahymena groups. EMBO J. 5:3625-30.

Stahl, D.A., Flesher, B., Mansfield, H. R., Montgomery, L. (1988). Use of phylogenetically based hybridization probes for studies of ruminal microbial ecology. Appl. Environ. Microbiol. 54:10791084 .

Steidinger, K.A. (1990). Species of the tamarensis/catenella group of Gonyaulax and the fucoxanthin derivative-containing gymnodiniods. In: Graneli, E., Sundstrom, B., Edler, L. \& Anderson ,D.M. [Eds]. Toxic Marine Phytoplankton. Elsevier, New York, pp. 11-6.

Steidinger, K.A, Moestrup, $\varnothing$. (1990). The taxonomy of Gonyaulax, Pyrodinium, Alexandrium, Gessnerium, Protogonyaulax and Goniodoma. In Graneli, E., Sundstrom, B., Edler, L. \& Anderson, D.M. [Eds]. Toxic Marine Phytoplankton. Elsevier, New York, pp. 522-3.

Taylor, F.J.R. (1985). The taxonomy and relationships of red tide dinoflagellates. In Anderson, D.M., White, A.W.\& Baden, D.G. [Eds.] Toxic Dinoflagellates. Elsevier, New York, pp. 11-26.

Waltz, B., Waltz, A. \& Sweeny, B.M. (1983). A circadian rhythm in RNA in the dinoflagellate, Gonyaulax polyedra. J. Comp. Physiol. 151:207-13. 


\section{Chapter 2}

\section{Identification of Group- and Strain-Specific Genetic Markers For Globally Distributed Alexandrium (Dinophyceae) Species}

I. Restriction Fragment Length Polymorphism Analysis of Small-Subunit Ribosomal RNA Genes 


\begin{abstract}
Two distinct small-subunit ribosomal RNA genes (SsrDNAs), termed the "A gene" and "B gene," were recently found in the toxic dinoflagellate Alexandrium fundyense (Halim) Balech. A restriction fragment length polymorphism (RFLP) assay was developed to rapidly detect the A and B genetic markers. SsrDNAs from fifty eight cultures with species designations of $\underline{\mathrm{A}}$. tamarense (Lebour) Balech,

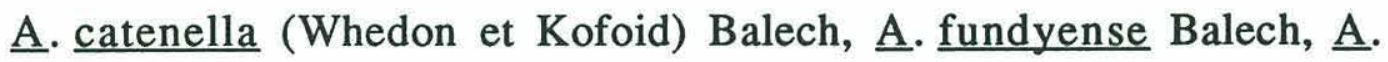
affine (Fukuyo et Inoue) Balech, $\underline{A}$. minutum Halim, $\underline{\text { A. }}$ lusitanicum Balech, and $\underline{\mathrm{A}}$. andersoni Balech were screened. These cultures represent isolates from North America, Western Europe, Thailand, Japan, Australia, and the ballast water of several cargo ships. The RFLP assay revealed five distinct groups among these isolates. Three subdivide the "․․tamarense/catenella/fundyense species complex," but do not correlate with morphospecies designations. The fourth group consists of $\underline{\text { A. }}$ affine isolates. The fifth group is represented by $\underline{\mathrm{A}}$. minutum, $\underline{\mathrm{A}}$. lusitanicum and $\underline{\mathrm{A}}$. $\underline{\text { andersoni. }}$.
\end{abstract}

The B gene was only found in Alexandrium tamarense, $\underline{\text { A. }}$. catenella and $\underline{A}$. fundyense, but not in all members of this closely-related group. Thus, there is no strict correlation between the presence of the $\mathrm{B}$ sequence and morphospecies designations. The B sequence is not essential for toxin production, but those organisms harboring it are toxic. The B gene is not uniformly distributed among global populations of

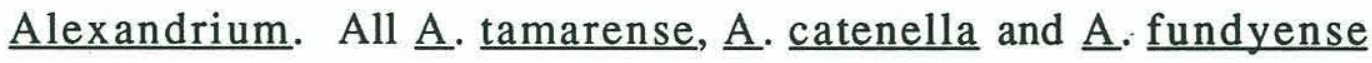
isolates from North America harbor this gene, but it has also 
been found in some $\underline{\mathrm{A}}$. tamarense from scattered locations in Japan, as well as in $\underline{A}$. $\underline{\text { tamarense }}$ from the ballast water of one cargo vessel which was on a defined run from Japan to Australia. The B gene may be endemic to North American

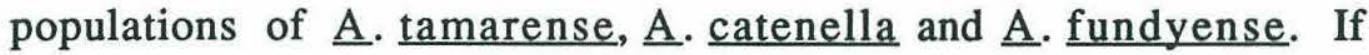
so, it is possible that in the recent past North American $\underline{\mathrm{A}}$. tamarense were introduced to Japanese waters, and a subset of these populations subsequently dispersed to Australia. The B sequence may be useful for tracking this particular populations' regional and/or global dispersal.

Isolates which do not harbor the B sequence appear to carry only a single class of small-subunit rRNA genes. However, since the enzymes used in the RFLP assay sample only a small number of bases in the A and B molecules, it is possible that other Alexandrium carry "B-like genes" that have not yet been detected. A more thorough search for these molecules is necessary to establish the uniqueness of the B gene and its apparent origin in North America. 


\section{INTRODUCTION}

Marine dinoflagellates within the genus Alexandrium (= Protogonyaulax Taylor; Steidinger and Moestrup 1990) include a number of species capable of producing potent neurotoxins. These toxins, typically referred to as paralytic shellfish poisons (PSP), can accumulate in filter feeding shellfish and thereby pose a serious health threat if consumed by humans (Prakash et al. 1971). Toxic Alexandrium are found in many regions of the world (Taylor 1984). Compelling evidence from a number of investigators suggest that these organisms have dispersed from source populations by both natural (Anderson 1989, Hayhome et al.1989) and human-assisted means (Anderson 1989, Hallegraeff et al. 1991, Hallegraeff and Bolch 1991, 1992). Because of the recognized dispersal and well-known hazards of PSP, Alexandrium species are receiving increased international attention. Rapid and unequivocal identification of these organisms has become one focal point of toxic dinoflagellate research. Here we report on the application of molecular biological methods for identifying strain-specific genetic markers in toxic and nontoxic Alexandrium species, and the use of these markers for classifying their globally-distributed populations.

At present, morphological characters are the primary means of describing Alexandrium species (Balech 1985, Steidinger 1990). The importance of morphological characters and their relationship to species- and strain-level classifications continues to be a subject of debate (Taylor 1990, 1985). An example centers on the toxigenic $\underline{\mathrm{A}}$. 


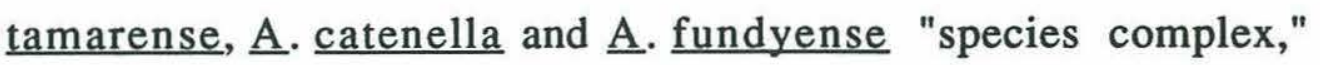
morphotypically-similar organisms that some consider different species (eg. Balech 1985, Balech and Tangen 1985) but others view as varieties or strains of one species (Taylor 1985, Cembella et al. 1988). Biochemical characters such as isozyme electrophoretic patterns (Cembella and Taylor 1986, Cembella et al. 1988, Hayhome et al 1989, Sako et al. 1990), toxin composition profiles (Cembella et al. 1987) and cell surface antigens (Sako et al. submitted) have been used to discriminate between isolates. In some cases the biochemical markers corroborate morphotaxonomic classifications (Sako et al. 1990; Sako submitted), but in other cases they do not (Cembella and Taylor 1986; Cembella et al. 1987, 1988; Hayhome et al 1989). As a consequence, the relationship between morphotype and biochemical or genetic characters, including toxicity, remains obscure. A further complication is the fact that taxonomic and biogeographic case studies to date have focussed primarily on regional rather than globally-distributed populations. It thus seems possible that some of the confusion concerning the validity of species designations may have arisen because different populations of the same morphospecies are genetically divergent.

Sequence analysis of genomic small-subunit (Ss) and largesubunit (Ls) ribosomal RNA (rRNA) genes (rDNA) is one method that could be used to classify populations of Alexandrium tamarense, $\underline{A}$. $\underline{\text { catenella }}$ and $\underline{\mathrm{A}}$. $\underline{\text { fundyense, }}$, as well as other Alexandrium species (Destombe et al. 1992, Scholin and Anderson 1992, Scholin et al. submitted). Sequences of rRNA and rDNA have been used 
extensively to evaluate the evolutionary histories of organisms (Olsen et al. 1986, Sogin et al. 1986, Field et al., 1988, Lenaers et al., 1991) and have gained recognition as species- and strain-specific genetic markers (Gobel et al. 1987, McCutchan et al. 1988, Stahl et al. 1988, Amann et al. 1990, Distel et al. 1991). It was reasoned that this well-established method might be useful in settling the dispute over fine-scale Alexandrium taxonomic criteria and could help elucidate the organisms' global population structure. A unified systematic scheme and classification of intraspecific genetic variation should also provide the necessary references for testing dispersal hypotheses.

A pre-requisite for all of these applications is acquiring, compiling and analyzing sequences from representative Alexandrium species collected from many locations throughout the world. As a first step in creating such a data base, we sequenced SsrDNAs from a clonal, toxic $\underline{\mathrm{A}}$. fundyense isolated from eastern North America. This analysis surprisingly revealed the existence of two distinct genes, subsequently named the "A gene" and the "B gene" (Scholin et al. submitted). Further study of these molecules suggested that the B sequence is a pseudogene (i.e., is non-functional). Because the $\mathrm{A}$ and B gene sequences vary little from each other ( 40 positions out of 1800), it is possible that divergence occurred relatively recently. This raised the interesting possibility that the B gene could be indicative of a specific population of $\underline{\mathrm{A}}$ f fundyense. However, the labor involved in identifying and documenting these two sequences using cloning and sequencing protocols made the prospects of 
examining a large number of cultures for the same genes difficult to justify.

A restriction fragment length polymorphism (RFLP) assay, termed the "A/B gene restriction test," was therefore developed to expedite the screening procedure. RFLP assays are a convenient means of rapidly determining sequence heterogeneity among defined DNA molecules. Because of the ease of applying the technique, its cost effectiveness and potential for revealing highly specific groups of organisms, these assays have been used extensively in taxonomic and ecological studies, as well as in forensic science (eg. Curran et al. 1985, Wetton et al. 1987, Goff and Coleman 1988, Moody 1989, Levy et al. 1991, Rowan and Powers 1991). The A/B gene restriction test allows for rapid detection of the $\mathrm{A}$ and $\mathrm{B}$ genetic markers using specific endonucleases which discriminate nucleotide differences between the $\mathrm{A}$ and $\mathrm{B}$ gene sequences. In this report we describe the development of the RFLP assay, its application to variety of Alexandrium species collected from diverse regions of the world and its utility for delineating specific populations of some of these organisms. In the following companion paper (Scholin et al. submitted manuscript), results of the RFLP assay are compared to detailed sequence analysis of a portion of the LsrDNA from a subset of the cultures examined herein. 


\title{
MATERIALS and METHODS
}

\author{
Culturing
}

Cultures used in this study are listed in Table 1; strain and species designations, isolation locale, and available toxicity information are also presented. All were maintained in $f / 2$ medium as modified and described by Anderson et al. (1984). Cultures that were obtained from sources other than the Anderson lab are as follows: PW05, PW06, PI32, IP02, ACQH01, ACQH02 (S. Hall); Gony.\#7 (A. White); Gt 429 (Provasoli-Guillard Culture Collection); Pgt 183 [North East Pacific Coast Culture collection (NEPCC 183]); PE1V, PE2V, PA5V and AL2V (I. Bravo); Gt Port (L. Provasoli); AM2 and AM3 (E. Erard-Le Denn); N 239 and N 520 [National Institute for Environmental Studies (NIES-Collection, Japan)]; ND-1, OK875-1, OF875-8, OF84423D3, WKS-1, WKS-3, WKS-8, CU-1 and CU-13 (M. Kodama); OF041, OF051, OF101 and TN9 (Y. Sako); ATJP01, ACPP01, ACPP02, АCPP03, АCPP09, AMAD01, AMAD06, АTBBO1, АABB01/2, I72/21\#2, I72/22\#2, I72/21\#4, АCJP03, G. Crux, G. Hope 1 and G. Hope 2 (G. Hallegraeff). All strains listed in Table 1 are currently maintained at the Woods Hole Oceanographic Institution.

Nucleic Acid Extraction

Approximately $10-15 \mathrm{~mL}$ of a mid-log culture were harvested by gentle centrifugation, and the cell pellet resuspended in approximately $200 \mu \mathrm{L}$ of autoclaved Milli-Q water (Millipore Corp.) at 
room temperature. The cell slurry was transferred to a $1.5 \mathrm{~mL}$ sterile microcentrifuge tube and adjusted to contain: $1 \%$ SDS, $10 \mathrm{mM}$ EDTA (pH 8.0), $10 \mathrm{mM}$ Tris $\mathrm{HCl}(\mathrm{pH} \mathrm{7.5)}$ and $10 \mathrm{mM} \mathrm{NaCl}$ in a final volume of $250 \mu \mathrm{L}$. Nucleic acids in this solution were purified by extracting once with tris-buffered phenol, 2-3 times with phenol:chloroform:isoamyl alcohol (PCI; 24:24:1) and once with chloroform:isoamyl alcohol (CI; 24:1; Ausubel et al. 1987). Total nucleic acids were precipitated by the addition of 2 volumes of icecold $100 \%$ ethanol and $1 / 10$ volume $3 \mathrm{M} \mathrm{NaOAc}(\mathrm{pH} 5.0$ ), followed by chilling at $-20^{\circ} \mathrm{C}$ for at least $2 \mathrm{~h}$. The precipitate was collected by centrifugation in a chilled $\left(4^{\circ} \mathrm{C}\right)$ Sorvall microfuge at $\sim 12,000 \mathrm{xg}$ for 15 min, supernatant was decanted, and the nucleic acid pellet rinsed with $80 \% \mathrm{EtOH}$ for at least $30 \mathrm{~min}$ at $-20^{\circ} \mathrm{C}$. After rinsing, the sample was spun again, the EtOH wash removed, the pellet briefly air-dried and then resuspended in $10-50 \mu \mathrm{L}$ of TE $(10 \mathrm{mM}$ Tris- $\mathrm{HCl}$ $\mathrm{pH} 7.5,1 \mathrm{mM}$ EDTA $\mathrm{pH} 8.0$ ). The concentration of DNA was determined by diluting an aliquot and reading its absorbence at $260 \mathrm{~nm}$ (Ausubel et al. 1987). DNA samples were stored at $-20^{\circ} \mathrm{C}$ until needed.

Polymerase Chain Reaction (PCR) Amplification of SsrDNAs

Complete -SsrDNAs- were-amplified using the polymerase chain reaction (PCR; Saiki et al. 1988) with universal eukaryotic primers (Sogin 1990) using a Perkin Elmer Cetus DNA Thermal Cycler and Perkin Elmer GeneAmp PCR Core Reagents as recommended by the manufacturers. Amplifications were typically carried out as follows: 
Table 1. Strain numbers, species designations, isolation locales and toxicity of Alexandrium cultures screened using the SsrDNA A/B gene restriction test. PCR amplification characteristics and results of the RFLP assays for each culture are indicated ("+").

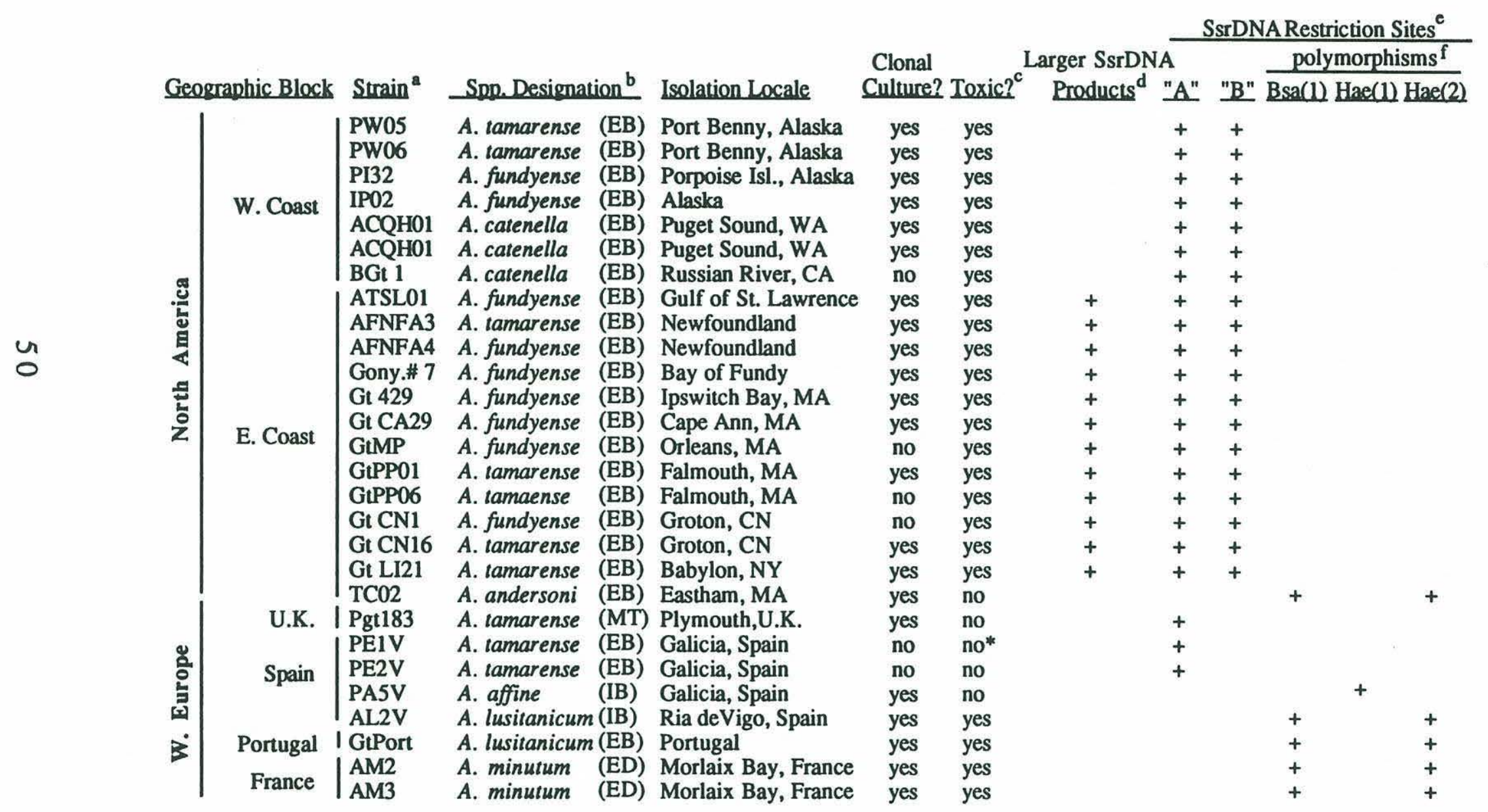




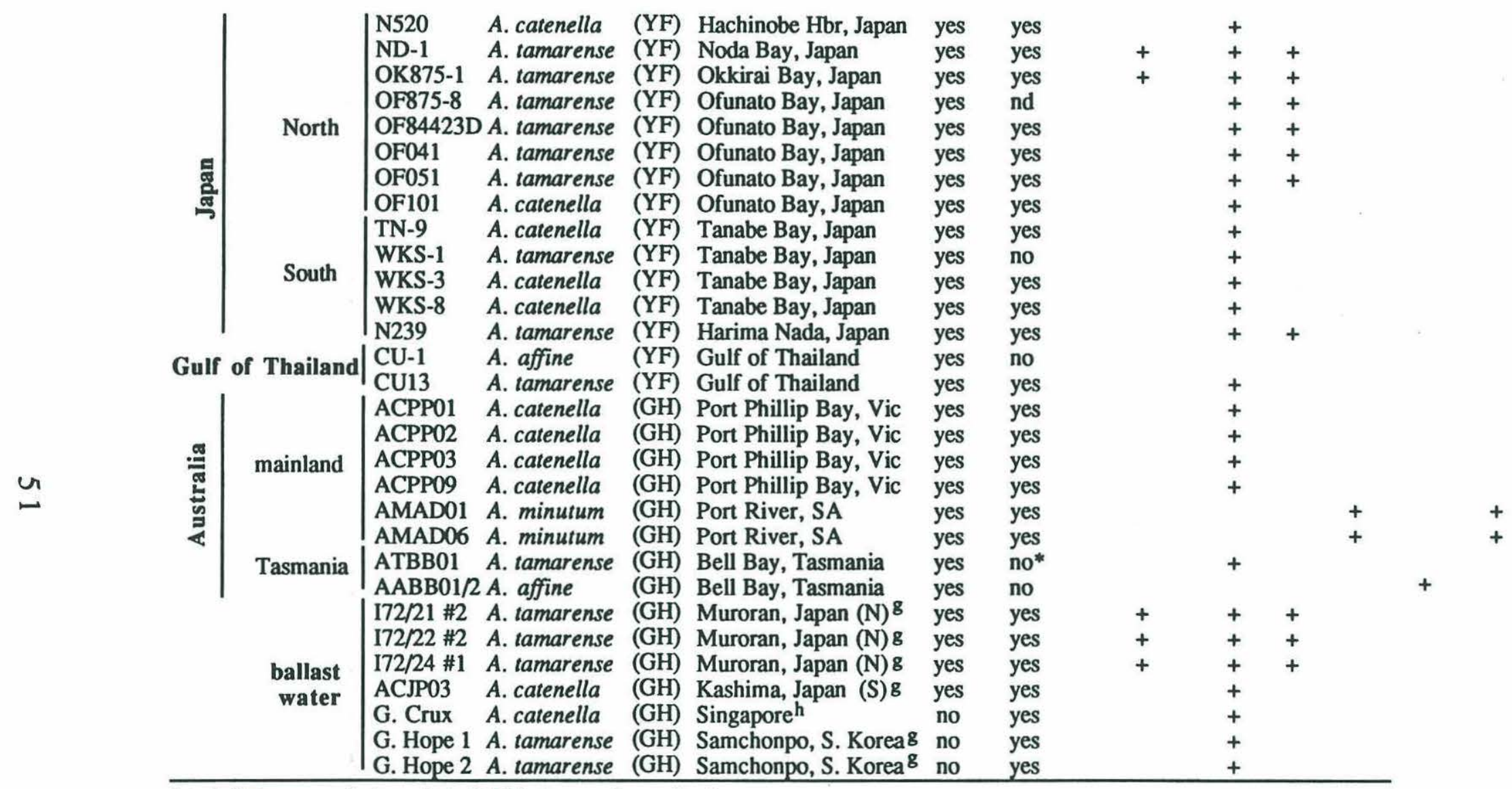

a) strain listings currently in use in the D.M Anderson culture collection

b) as determined by (or using the criteria of): E. Balech (EB), F.J.R. Taylor (MT), I. Bravo (IB), E. Erard-Le Denn (ED), Y. Fukuyo (YF) and G. Hallegraeff (GH)

c) determined by mouse bioassay and/or HPLC anaylsis; "nd" indicates "not determined;" "*" - may contain trace amounts of toxin (D. Kulis, pers.comm.)

d) indicates presence of $P C R$ products larger than expected (see Fig. 2b)

e) presence of restriction sites characteristic of the A gene (Bsr I digestion; "A"), the B gene (Bsa AI; "B"), and both genes (Hae III and Xba I digestions; Fig. 2 a)

f) deviations from predicted restrction patterns based on the sequences of the A and B genes; "Bsa(1)" - anomalous Bsa Al restriction pattern; "Hae(1)" and "Hae(2)" anomalous Hae III restriction patterns (see Figs. 2a, $c$ and $\mathrm{e}$ )

g) presumed origin (Hallegraeff and Bolch 1992)

h) hailing port of vessel - origin of ballast water uncertain (Hallegraeff and Bolch 1992) 
denaturing at $92^{\circ} \mathrm{C}-1.5 \mathrm{~min}$; cooling to $45-55^{\circ} \mathrm{C}-30 \mathrm{sec}$; annealing at $45-55^{\circ} \mathrm{C}-1.5 \mathrm{~min}$; warming to $72^{\circ} \mathrm{C}-1.5 \mathrm{~min}$; and, extension at $72^{\circ} \mathrm{C}-2.0 \mathrm{~min}$. This cycle was repeated 30 times with an auto extension (5 sec/cycle). PCR reactions for a given DNA preparation were done in duplicate or triplicate. Optimal, final concentrations of primers were found to be $0.01-0.05 \mu \mathrm{M}$, (depending on the DNA preparation used) using $3 \mathrm{mM} \mathrm{MgCl} 2$ and $1 \mathrm{ng}$ of total DNA (when necessary, dilutions of DNA were made in autoclaved Milli-Q water). Following amplification, replicate reactions were pooled and purified by extracting once with PCI and once with CI. The products were concentrated by standard EtOH precipitation and resuspended in 10$50 \mu \mathrm{L}$ of $\mathrm{TE}(\mathrm{pH} 7.5) ; 1 \mu \mathrm{L}$ of this was run on anarose gel and its relative intensity compared to standards in order to determine an approximate concentration (ng/ $/ \mathrm{L})$. Amplified SsrDNAs were stored at $-20^{\circ} \mathrm{C}$ until needed.

\section{A/B Gene Restriction Test}

Theoretical restriction maps of the A and B sequences (Scholin et al., submitted) were generated using MacDNASIS Pro (v. 1.0; Hitachi) DNA analysis software. The resultant cleavage sites of each enzyme found to recognize one or both of the genes were then compared - to determine-which-enzymes-would-discriminate between the two genes.

Bsa AI, $\underline{B s r I}, \underline{\mathrm{Hae}}$ III, and $\underline{\mathrm{Xba}}$ I were chosen for the RFLP analysis of PCR-amplified SsrDNAs. Approximately 50-100 ng of PCR 
product was digested with each of the enzymes as directed by the manufacturer (New England Biolabs) in 10-25 $\mu \mathrm{L}$ reactions for 1-3 hrs. Products of the digestions were resolved on $1.0-1.5 \%$ agarose gels using 1X TBE buffer (Ausubel, 1987). Digesting a particular isolate's SsrDNA with each of the four enzymes, separating the products on an agarose gel and scoring the resultant pattern constitutes the "A/B gene restriction test."

\section{Results}

Theoretical Restriction Maps of the A and B Genes

Computer-assisted restriction site analysis of the $\mathrm{A}$ and $\mathrm{B}$ sequences resulted in the identification of over 100 enzymes that would theoretically cleave at one or more locations in one or both of the genes (data not shown). After initial comparisons, eighteen candidate enzymes were identified that should differentially recognize the two sequences, along with two enzymes that were expected to cleave the genes at identical locations [Scholin, Ph.D. thesis(Appendix B)]. From this list, $\underline{\mathrm{Bsa}} \mathrm{AI}, \underline{\mathrm{Bsr}} \mathrm{I}, \underline{\mathrm{Hae}} \mathrm{III}$, and $\underline{\mathrm{Xba}} \mathrm{I}$ were chosen to test the validity of the computer predictions (Figs. 1 and $2 a)$. 
Application of the A/B Gene Restriction Test

The suite of chosen enzymes was initially tested on PCRamplified SsrDNAs from Alexandrium fundyense (strain GtCA29), the isolate in which the A and B genes were first identified (Scholin et.al, submitted). This yielded products as predicted by the computer model (Fig. 2a; Fig. 2b-f, lane I). However, the PCR products also contained a relatively small proportion of molecules that were $\sim 300 \mathrm{bp}$ greater than the expected product of $1800 \mathrm{bp}$ [Fig. 2b, lane 1; occasionally the larger band resolves into two fragments that are $\sim 200 \mathrm{bp}$ and $\sim 400 \mathrm{bp}$ greater than the A and B genes (cf. Scholin and Anderson, 1992)]. In addition, Bsa AI digestion gave rise to two unpredicted, minor fragments (Fig. 2a; Fig. 2c, lane I).

SsrDNAs from an additional fifty seven Alexandrium cultures with species designations of $\underline{A}$. tamarense, $\underline{A}$. catenella, $\underline{\text { A. }}$ fundyense,

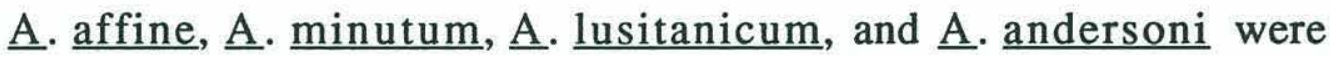
screened with the same suite of enzymes used in the pilot test. These cultures include both toxic and non-toxic isolates from North America, Western Europe, Thailand, Japan, Australia, and the ballast water of several cargo ships (Table 1). The A/B gene restriction test revealed five distinct clusters among these cultures. Representative amplification and restriction patterns for each of the groups are shown in Figs. 2b-f. Table 2 presents a summary of these characteristics, and their relationship to morphospecies designations, toxicity determinations and geographic origins of the cultures. 


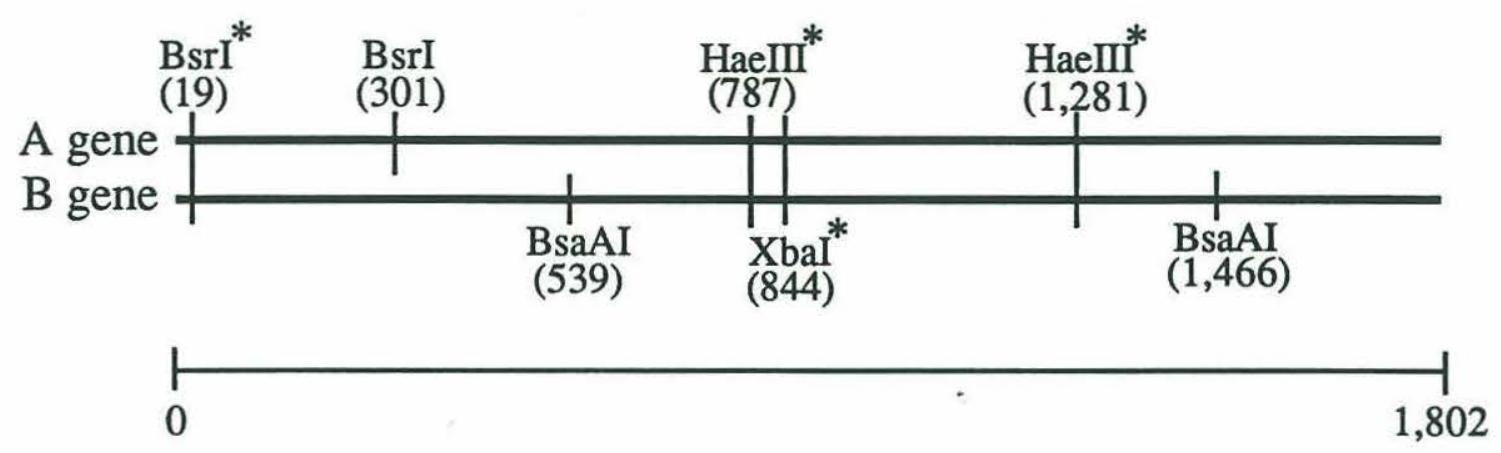

Figure 1. Composite restriction maps of the A and B genes showing the relative positions of cut sites for all endonucleases used in the $A / B$ restriction test (note the scattered location of recognition sequences). Restriction sites common to both genes are indicated by "*." Numbers refer to the nucleotide distal to the cleavage and are relative to the position in the A gene. The bottom scale refers to the length of the A gene ( 1,802 base pairs). 
Figure 2. SsrDNA A/B gene restriction test. 2a: schematic representation of the assay. Restriction maps of A and B genes for Bsa AI (B cutter), Bsr I (A cutter), Hae III and Xba I (A/B cutters) are shown on top; numbers refer to the nucleotide distal to the cleavage and are relative to the position in the A gene. Schematized agarose gels of predicted digestion products are shown below the restriction maps; numbers refer to length of the fragments in base pairs. 2b-f: agarose gels of representative PCR amplification (2b) and restriction patterns (2c-f) of identified Alexandrium SsrDNA RFLP groups. Agarose gel lane designations are as follows: "S"= size standards (length in base pairs is indicated on the left); "I"= Group I $\underline{A}$. fundyense

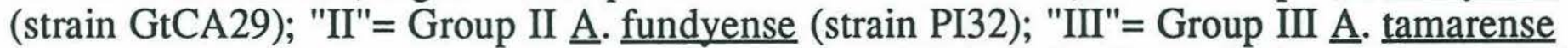
(strain Pgt183); "IV"= Group IV $\underline{\text { A }}$. affine (strain PA5V); "V"= Group V $\underline{\mathrm{A}}$. minutum (strain AMAD06). Arrowheads point to: $2 \mathrm{~b}-\mathrm{SsrDNA}$ PCR products $(\sim 1,800$ base pairs) and larger products ("*") found in Group I; and, 2c-f - A/B digestion fragments (in base pairs) predicted for each enzyme (2a). Observed digestion fragments are essentially identical to those predicted for Groups I and II. Exceptions to the predictions are as follows: minor Bsa AI products (2c, lanes I and II); and, the "Hae (1)" (2e, lane IV), "Bsa(1)" and "Hae(2)" (2c and e, Lane V) RFLPs (see Table 2). Restriction patterns of Groups III-V do not indicate presence of the B gene or SsrDNAs analogous to the B gene. There was some variation in the total amount of DNA loaded into each lane; this is especially noticeable in $2 \mathrm{c}$ and d, lane II. 


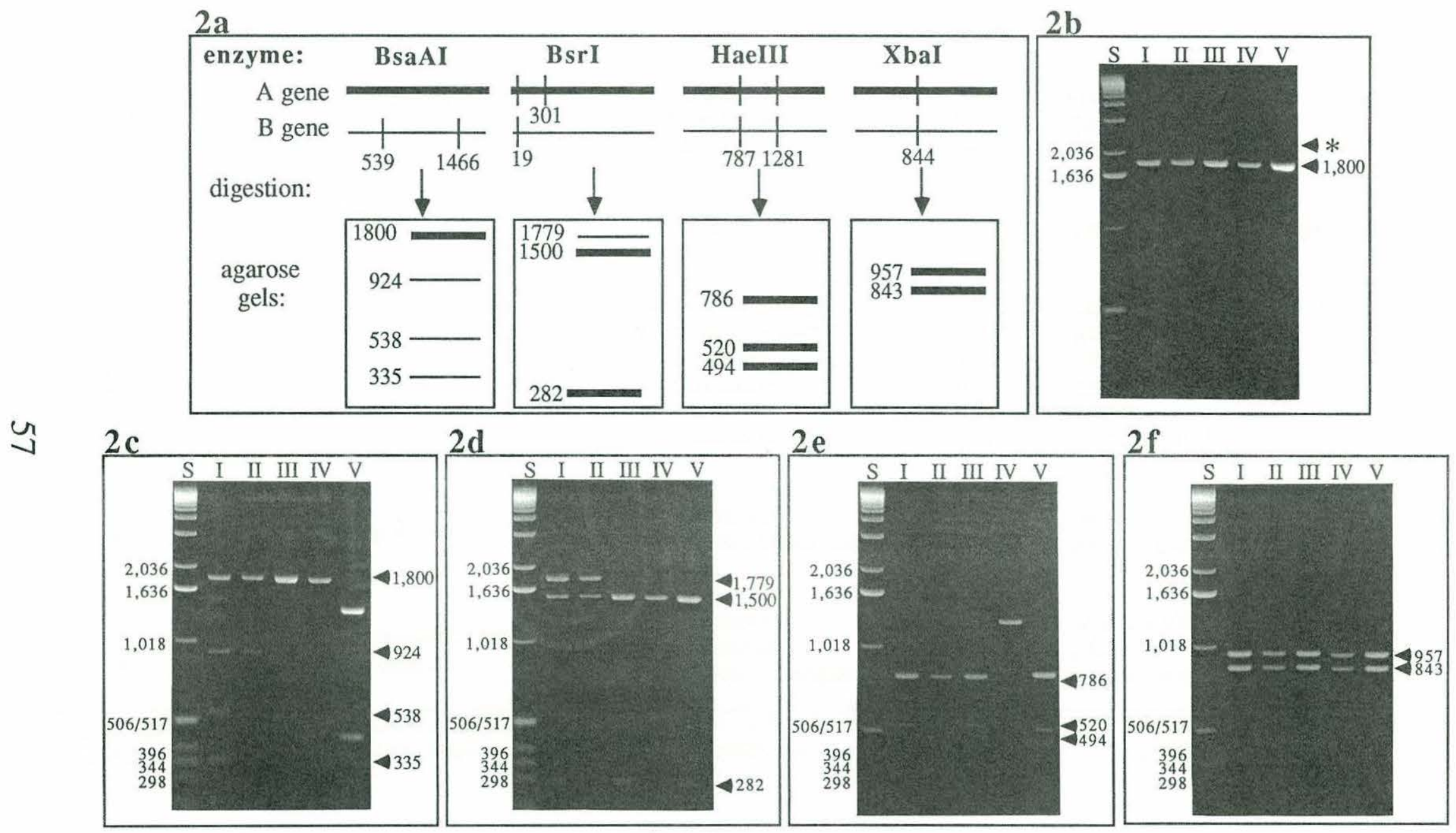


Table 2. Summary of SsRDNA RFLP group characteristics, representative species, known toxicity data and isolation locales of Alexandrium cultures screened using the the A/B gene restriction test.

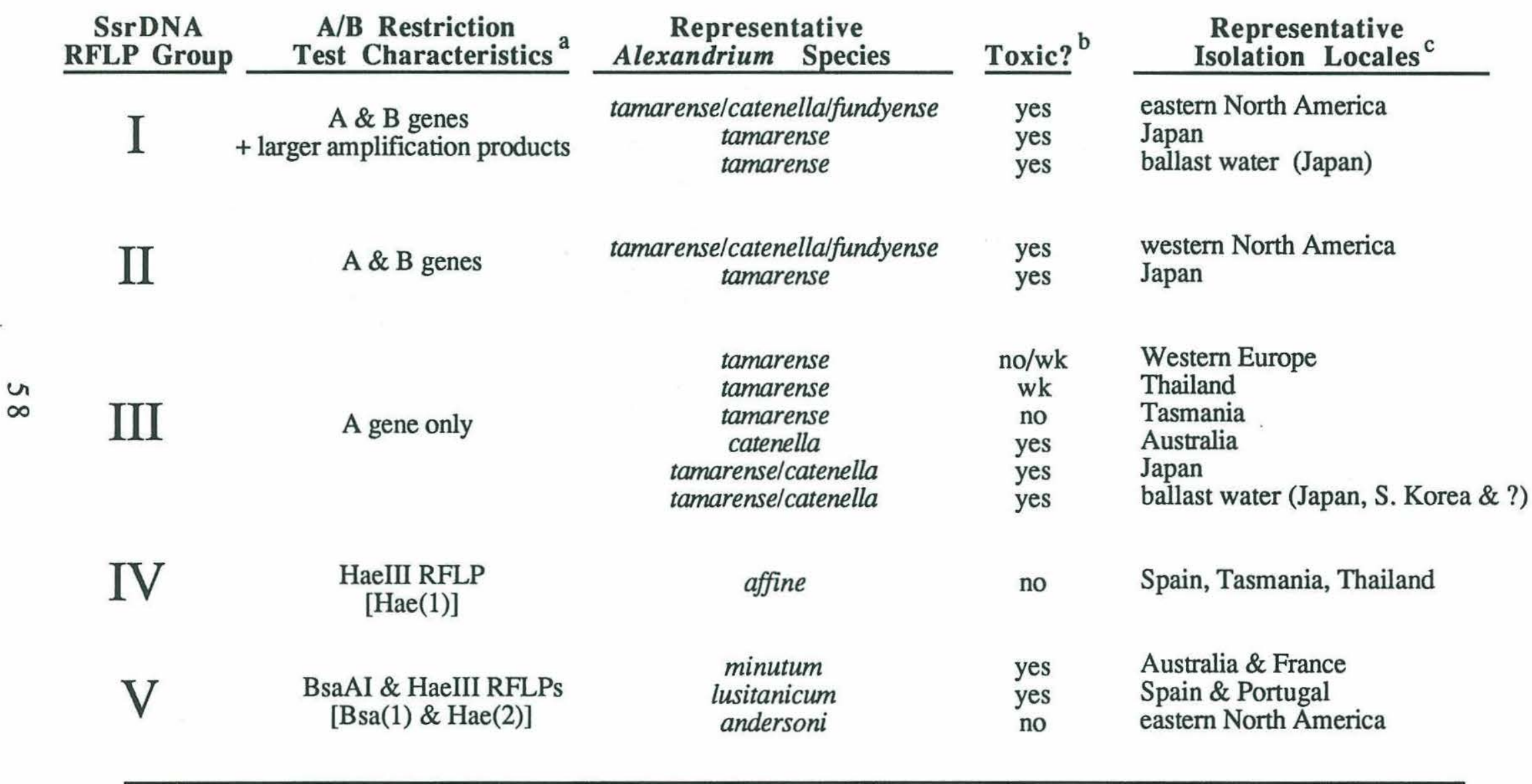

a) see Fig. 2

b) toxicity data for one Group II cultures is lacking; "wk" refers to "weakly toxic"

c) some geographic regions are represented by only one or several isolates; the origin of one ballast water culture ("?") is not known (see Table 1) 
Groups I-III: Subdivisions of the $\underline{A}$. tamarense, $\underline{\text { A. catenella }}$ and A. fundyense Species Complex

Three of the groups identified by the RFLP assay are subsets of the closely-related $\underline{\text { Alexandrium tamarense/catenella/fundyense }}$ species complex, an assemblage which includes both toxic and nontoxic representatives. All share the predicted A gene restriction pattern, but differ in the presence or absence of the larger SsrDNA amplification products, and whether or not they carry the B gene (Fig. 2a; Figs. 2b-f, lanes I-III; Table 2). Group I is typified by isolates that display the larger amplification products and both the A and B genes (Fig. 2a; Figs. 2b-f, lane I). This includes all eastern

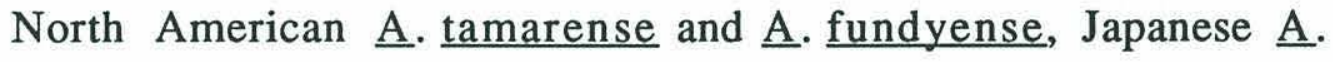
$\underline{\text { tamarense }}$ isolated from Okkirai and Noda Bays, and $\underline{\text { A. }}$ tamarense from the ballast water of one cargo vessel. Group II is comprised of isolates which do not display the larger amplification products, but do harbor the A and B genes (Fig. 2a; Figs. 2b-f, lane II). Group II includes all $\underline{\mathrm{A}} . \underline{\text { tamarense }}, \underline{\mathrm{A}} . \underline{\text { catenella }}$ and $\underline{\mathrm{A}}$. $\underline{\text { fundyense }}$ from western North America and several $\underline{A}$. tamarense from Ofunato Bay, Japan. Both Groups I and II display minor Bsa AI digestion products not predicted by the computer-generated restriction maps (Fig. 2a; Fig. 2c, lanes I-II). Group III exhibits a restriction pattern for the A gene alone, having neither the larger amplification products, nor the B gene patterns, nor any unpredicted patterns (Fig. 2a; Figs. 2b-f, lane III). Group III encompasses $\underline{A}$. tamarense and $\underline{\text { A. }}$ catenella isolated from Western Europe, Japan, Australia and the ballast water of three cargo vessels (Tables 1 and 2). 
Group IV: $\underline{\text { A. affine }}$

Non-toxic Alexandrium affine from Spain Tasmania and Thailand exhibit Hae III digestion products that are not predicted on the basis of the known A and B sequences (Fig. 2a ; Fig 2e, lane IV). This restriction pattern was designated "Hae(1)" (Tables 1 and 2). The Hae(1) feature is the distinguishing characteristic of Group IV.

Group V: $\underline{\mathrm{A}} . \underline{\text { minutum}}, \underline{\mathrm{A}} . \underline{\text { lusitanicum}}$, and $\underline{\mathrm{A}}$. $\underline{\text { andersoni }}$

The toxic Alexandrium minutum and $\underline{\text { A. }} \underline{\text { lusitanicum, and non- }}$ toxic $\underline{\mathrm{A}}$. andersoni also share unique restriction patterns that vary from those predicted on the basis of the known A and B gene sequences. Each display both a Bsa AI and Hae III RFLP, designated "Bsa(1)" and "Hae(2)," respectively (Fig. 2a; Figs. 2 c and e, lane V; Tables 1 and 2). The $\mathrm{Bsa}(1)$ and $\mathrm{Hae}(2)$ patterns were not observed in SsrDNA from any other isolates. When present, the Bsa(1) and Hae(2) RFLPs always co-occurred and were used as the basis for the Group V assignments.

\section{DICUSSION}

Results of the present study demonstrate that the $A / B$ restriction test is a rapid and effective means of determining sequence heterogeneity among PCR-amplified SsrDNAs from a variety of Alexandrium species. The RFLP patterns indicate that the A. tamarense/catenella/fundyense complex is composed of at least 
three genetically distinct strains which do not strictly correspond to the three morphospecies designations. Instead, it appears these strains are representative of geographically-isolated populations. The RFLP analysis also indicates that this large species complex is

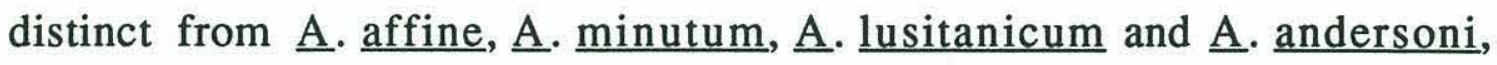
regardless of geographic origin. The $\mathrm{A} / \mathrm{B}$ restriction test further subdivides the latter group of species, with $\underline{A}$. affine being distinguishable from the $\underline{\mathrm{A}} . \underline{\mathrm{minutum}} / \underline{\mathrm{lusitanicum} / \underline{\mathrm{anders}} \text { oni }}$ cluster. As currently defined, the RFLP screening procedure thus resolves relationships among Alexandrium species and strains (or populations). As additional enzymes are incorporated in the screening procedure, resolution of the assay should improve.

The A/B Gene Restriction Test

Sequencing of the $\mathrm{A}$ and $\mathrm{B}$ genes is labor intensive and expensive because it requires analysis of multiple SsrDNA clones to document both molecules and their respective nucleotide differences. The prospects of screening a large number of isolates for these genetic markers using conventional sequencing techniques is therefore daunting, yet the $\mathrm{A}$ and $\mathrm{B}$ sequences clearly have the potential to be specific for a given population of toxigenic Alexandrium. A compromise approach was to create theoretical restriction maps of the known $\mathrm{A}$ and $\mathrm{B}$ sequences and identify enzymes that could distinguish between the genes, thereby providing a basis for their rapid detection. When both genes are present, enzymes which discriminate between the two sequences should give 
rise to restriction fragments whose sum is approximately twice (or at least greater than) the size of the PCR-amplified SsrDNAs. In contrast, an enzyme which cleaves both genes in identical locations will produce restriction fragments whose sum is equal to that of the PCR product (Fig. 2a). The latter result is also expected when only a single gene is present.

As a first step in testing the validity of the theoretical restriction maps, $\underline{B s r} \mathrm{I}$ and $\underline{B s a} \mathrm{AI}$ were chosen to differentiate between the A and B genes, respectively, in PCR-amplified SsrDNAs from a DNA preparation known to contain both sequences (Alexandrium fundyense GtCA29). As a further test of the computer predictions, $\underline{\mathrm{Hae}}$ III and $\underline{\mathrm{Xba}} \mathrm{I}$ were also included because they are expected to cleave both genes in identical locations and their restriction sites fall roughly between those of BsrI and BsaAI (Fig. 1). The results of the pilot test proved that the A and B genes can be reproducibly amplified from the DNA preparation in which they were originally found, that both sequences appear to be present in roughly equal amounts (as predicted from previous sequence analyses; Scholin et al., submitted) and, with the exception of the two minor fragments seen in the Bsa AI digestion, the chosen enzymes' predicted restriction maps are accurate. Both genes are visually easy to detect with the enzymes and gel conditions chosen.

The success of the pilot test suggested that the RFLP assay was a viable means for rapidly determining if a particular isolate carried the A and B genetic markers. Therefore, the same suite of enzymes 
were used to screen SsrDNAs from fifty eight additional Alexandrium cultures with a variety of species designations and isolation locales. Results of these tests revealed five distinct PCR amplification and restriction patterns among the Alexandrium cultures. Several of the groups' distinguishing features are based upon fortuitous observations never predicted during the conception of the restriction test.

Groups I-III: Strains of Alexandrium tamarense, $\underline{\text { A. catenella and }}$ A. fundyense

Three distinct groups within the Alexandrium tamarense/ catenella/fundyense complex can now be recognized on the basis of their SsrDNA characteristics (Fig. 2a; Figs. 2b-f, lanes I-III; Table 2;

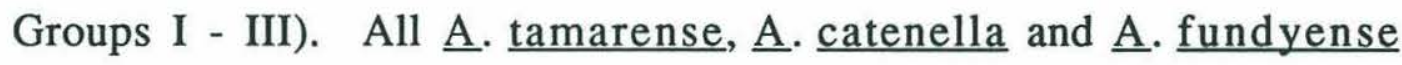
examined share the predicted A gene restriction pattern. The primary subdivision among this large group stems from those isolates which carry the B gene (Groups I and II) and those that do not (Group III).

Cultures harboring the B gene are further distinguishable on the basis of whether their SsrDNA PCR products include molecules larger than those expected (Group I) and those whose PCR products appear homogeneous (Group II; Tables 1 and 2). Initially, presence or absence of the larger products was considered to be an artifact of the PCR process. Repeated attempts to optimize the amplification reactions failed to eliminate the apparently spurious molecules, but 
otherwise resulted in highly specific amplifications (Fig. 2b).

Preliminary analysis of the larger products strongly suggests they are Alexandrium SsrDNAs that contain a repeated portion of the small-subunit gene in the $3^{\prime}$ half of the sequence (Appendix B). The distinction between Groups I and II is further supported by sequence analysis of a fragment of these isolates' LsrDNAs (Chapt. 3, Appendix C).

A peculiar characteristic of the B sequence found in both Groups I and II is that it appeared to comprise approximately half of the PCR-amplified product. There was little-to-no variation in these proportions. If the ratio of the PCR products reflects the relative abundances of the genes in the extracted DNAs, then it is possible that half of the ribosomal transcription units in these organisms contain a B sequence. The mechanism responsible for maintaining such a high copy number of an apparent pseudogene remains a mystery. Another consistent characteristic of PCR-amplified B genes is the unpredicted (but minor) BsaAI digestion products. The minor bands appear to originate from molecules which contain only one of the two predicted B sequence BsaAI sites. Partial digestion of the B gene is one explanation for the appearance of these minor products, but increasing enzyme concentration and time of digestion does not eliminate them (data not shown). Consequently, the minor bands likely originate from chimeric molecules - SsrDNAs which include a 5' portion of the A gene and $3^{\prime}$ portion of the $\mathrm{B}$ gene, or $5^{\prime}$ portion of the $\mathrm{B}$ gene and 3' portion of the A gene. It is possible these chimeras are generated during the PCR reaction by template strand switching 
(Erlich et al. 1991), or represent a minor class of SsrDNA that exists in vivo.

The B Genes' Relationship to Morphospecies Designations and Toxicity

There is no strict relationship between SsrDNA RFLP group and tamarensoid, catenelloid or fundyensoid morphotypes. Both positive and negative correlations between morphospecies designations and RFLP patterns are possible (Table 2). For example, OF041 (Alexandrium tamarense) and OF101 (․․ catenella), both from Japan, are members of Groups II and III, respectively. Distinctions based on morphotype and "genotype" for these two isolates are in

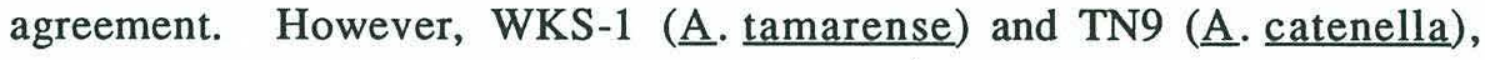
which are also from Japan, are both members of Group III. In this case there is no correlation between morphotype and "genotype." Another example of both positive and negative correlations between morphospecies designations and RFLP patterns can be found among the ballast water isolates I1724\#1, ACJP03 and G. Hope 1: I1724\#1 (․․ tamarense) and ACJP03 (․․ catenella) belong to Groups I and III, respectively; however, I1724\#1 (‥ tamarense) and G. Hope 1 (ㅅ․ tamarense) are also members of Groups I and III, respectively. Thus, different populations of the various morphospecies can appear genetically similar or divergent; the observed relationships in any given comparison depend on the geographic origin of the cultures, as well as the particular strains chosen for analysis (see Table 2). This may explain why the correlation between morphology and biochemical characteristics for different regional populations of 
$\underline{A} . \underline{\text { tamarense }}, \underline{A}$. catenella and $\underline{\mathrm{A}}$. $\underline{\text { fundyense }}$ have not been consistent (Cembella and Taylor 1986; Cembella et al. 1987, 1988; Hayhome et al 1989, Sako et al 1990). The latter conclusion has been examined in greater detail and is further substantiated by combining the RFLP assay with detailed sequence analysis of a portion of the LsrDNA (Chapt. 3).

A possible explanation for the disparity between SsrDNA RFLP patterns and Alexandrium tamarense/catenella/fundyense morphospecies designations could be the fact that different taxonomists classified the cultures. This is unlikely since examples of positive and negative correlations between morphotype and RFLP patterns can be found within groups of cultures examined by the same taxonomist. In the examples cited above, the Japanese isolates were classified by Fukuyo, and the ballast water isolates were classified by Hallegraeff. The same same is found for isolates examined by Balech (Tables 1 and 2). Therefore, agreements or disagreements between morphology and SsrDNA RFLP group are not a function of the taxonomist.

Another important conclusion from the A/B gene restriction tests is that not all toxigenic Alexandrium carry the B sequence. This holds true both within the closely-related $\underline{A}$. tamarense/catenella/ $\underline{\text { fundyense }}$ group, as well as the more distantly-related $\underline{A}$. affine, $\underline{A}$. lusitanicum, and $\underline{A}$. minutum (Tables 1 and 2). Though the B gene is not essential for toxin production, thus far all of those organisms 
which harbor it are toxic (Table 2). Rigorous assessment and interpretation of this pattern awaits further study.

\section{Biogeography}

The B gene and minor amplification products are not found among all isolates of Alexandrium tamarense, $\underline{\mathrm{A}}$. catenella and $\underline{\mathrm{A}}$. fundyense (Table 2): eastern North American isolates belong to Group I; western North American isolates belong to Group II; and, Australian, western European and the weakly toxic isolate from Thailand are within Group III. In contrast, isolates from Japan were found among all three groups. Ballast water isolates believed to have originated from specific blooms in Japan (Table 1; Hallegraeff and Bolch 1992) reinforce our conclusion that Japanese populations of $\underline{A}$. $\underline{\text { tamarense }}$ and $\underline{\mathrm{A}}$. catenella are genetically diverse: one ship ballasted in Muroran, Japan, contained Group I $\underline{A}$. tamarense, while a second ballasted in Kashima, Japan, carried a Group III A . catenella.

It is noteworthy that the SsrDNA RFLP patterns among

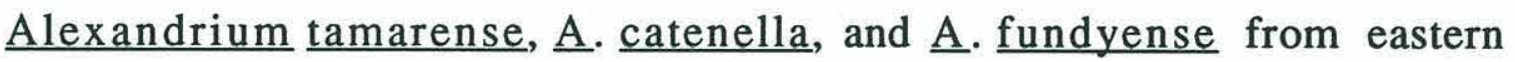
and western North America are so strongly correlated with their isolation locales (Table 2). It is possible that Group I and II characteristics reflect genetic markers indicative of eastern and western North American regional populations, respectively. Equally noteworthy is the fact that $\underline{\mathrm{A}}$. tamarense and $\underline{\mathrm{A}}$. catenella cultures from Japan display such a variety of SsrDNA signatures. One explanation would be that multiple strains of these species have 
been introduced to Japan from genetically distinct source populations in other regions of the world. If this is the case, then some contemporary Japanese Alexandrium may be the descendants of North American populations. In this context, it is of note that PSP first became a problem in Japan in the late 1940's (Anraku, 1984).

The occurrence of Group I Alexandrium tamarense in the ballast water from Muroran, Japan, is also of particular interest. This ship was on a defined run between Japan and Australia and apparently has never been to North America (Hallegraeff, pers. comm.), yet it contained $\underline{\text { A. }} \underline{\text { tamarense }}$ that are "identical" to those in eastern North America (see also Scholin et al., submitted manuscript). Therefore, some North American strains of $\underline{\mathrm{A}}$. $\underline{\text { tamarense }}$ may have not only been introduced to Japan, but possibly have been transported from Japan to Australia. A more detailed discussion of the B gene's relationship to toxic North American Alexandrium populations and its usefulness for tracing particular strains' movements throughout the globe is presented in Chapter 4.

The Alexandrium affine and the $\underline{A}$. minutum/lusitanicum/andersoni Groups

Isolates of $\underline{\text { Alexandrium affine, }} \underline{A}$. minutum, $\underline{\text { A. lusitanicum }}$ and A. andersoni were included in the $A / B$ restriction tests because they are considered to be taxonomically distinct from the $\underline{\mathrm{A}}$. tamarense/ catenella/fundyense complex. Given the significant morphological differences between the two complexes (Balech 1985, Balech and 
Tangen 1985), it is not surprising that their SsrDNA sequences would be different as well. The unique $\underline{\mathrm{Hae}}$ III and $\underline{\mathrm{Bsa}} \mathrm{AI}$ restriction patterns identified are a reflection of this divergence and fortuitously made it possible to subdivide $\underline{A}$. affine $\underline{A}$. minutum, $\underline{A}$.

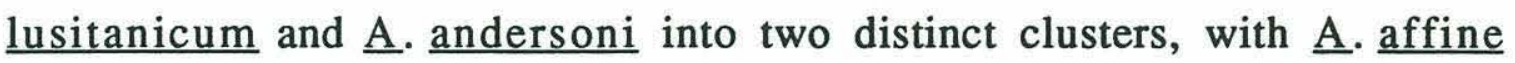
being separate from the other species (Figure 2, Table 2). There is no evidence for multiple small-subunit rRNA genes within $\underline{A}$. affine, $\underline{A}$. minutum, $\underline{\mathrm{A}} . \underline{\text { lusitanicum }}$ and $\underline{\mathrm{A}}$. andersoni since the sum of the restriction products for each individual digest roughly equals that of the PCR products.

SsrDNAs from Alexandrium minutum, $\underline{\mathrm{A}}$. $\underline{\text { lusitanicum, }}$ and $\underline{\mathrm{A}}$. andersoni all showed the $\mathrm{Hae}(2)$ and $\mathrm{Bsa}(1)$ RFLPs, patterns that constitute the Group V designation. Species within in Group V have been separated on the basis of fine-scale morphological variations (Balech 1985), but it is been suggested that these may simply be variants of the "same" species (Hallegraeff, pers. comm.). The restriction enzymes employed in the A/B restriction tests support Hallegraeff's contention. $\underline{\mathrm{A}}$. minutum, $\underline{\mathrm{A}}$. lusitanicum, and $\underline{\mathrm{A}}$. andersoni share common restriction patterns, and thus are more closely related to each other than to $\underline{\mathrm{A}}$. $\underline{\text { affine }}$ or members of the $\underline{\mathrm{A}}$. tamarense/ $\underline{\text { catenella/fundyense }}$ complex. However, more detailed sequence analysis of large subunit rDNA is able to resolve possible

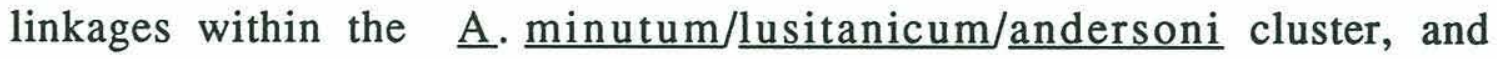
indicates that $\underline{\mathrm{A}}$. $\underline{\text { andersoni }}$ is distincly different from $\underline{\mathrm{A}}$. minutum/ lusitanicum (Chapt. 3). 
The distinction between those organisms in Groups I - III with those in Groups IV and V is consistent with current taxonomic designations. That is, results of the RFLP assay agree that the Alexandrium tamarense/catenella/fundyense group as a whole is

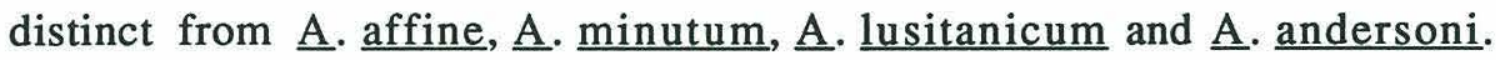
The further delineation between $\underline{\mathrm{A}}$. affine (Group IV) and $\underline{\mathrm{A}}$.

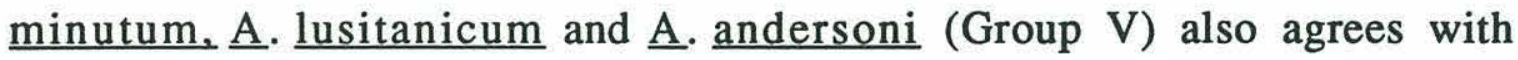
current morphotaxonomic designations.

Conclusions

These results clearly demonstrate that SsrDNAs are sufficiently variable to separate closely-related Alexandrium species or populations. The $\mathrm{A} / \mathrm{B}$ gene restriction test is a technically simple way to reveal these genetic differences. It should be possible to move beyond the work presented here to devise highly specific tests for defined groups of Alexandrium species and strains of single species by increasing the number of enzymes or by obtaining complete SsrDNA sequences. The growing RFLP pattern and sequence data bases could thus serve as genetic criteria for characterizing isolates and predicting their potential toxicity or geographic origins. In addition, the elucidation of genetically-distinct populations of $\underline{A}$.tamarense, $\underline{\text { A. }} \underline{\text { catenella }}$ and $\underline{A}$. $\underline{\text { fundyense }}$ begins to shed light on the long standing controversy over correlations between morphological and biochemical characteristics. Further definition of strain-specific markers should make retrospective analyses of these debates possible. 
A limitation of the $\mathrm{A} / \mathrm{B}$ gene restriction test as currently defined is that it samples only three of the forty known nucleotide differences between the two sequences. If the B gene is no longer under selective pressure it may be undergoing rapid evolution; consequently, further resolution of sexually-isolated populations that carry this sequence ("B gene sub-groups") is possible. It is also possible that isolates within Groups III-V carry "B-like genes" (i.e., other SsrRNA pseudogenes) were not detected by the RFLP assay. Establishing the existence of "B gene sub-groups" and "B-like sequences" are important areas of future research that must be taken into account prior to making rigorous conclusions based on the "uniqueness" of the B gene. This can be approached by increasing the number of endonucleases used in the RFLP analysis, or by sequencing SsrDNAs from additional isolates.

\section{LITERATURE CITED}

Amann, R.I., Krumholz, L., Stahl, D.A. (1990a). Fluorescentoligonucleotide probing of whole cells for determinative, phylogenetic, and environmental studies in microbiology. J. Bact. 172:762-770.

Anderson, D.M. (1989). Toxic algal blooms and red tides: a global perspective. In : Okaichi,T., Anderson, D.M., and Nemoto,T. (eds.) Red tides: biology, environmental science and toxicology. Elsevier, New York, pp. 11 - 20.

Anderson, D.M., Kulis, D.M., Binder, B.J. (1984). Sexuality and cyst formation in the dinoflagellate Gonyaulax tamarensis: cyst yield in batch cultures. J.Phycol. 20: 418-425. 
Anraku, M. (1984). Shellfish poisoning in Japanese waters. In: White, A.W., Anraku, M., Hooi, K.-K. (eds.) Toxic red tides and shellfish toxicity in southeast Asia. Southeast Asian Fisheries Development Center, Singapore, and the International Development Research Centre, Ottawa, Canada. pp. 105 - 109.

Ausubel, F.M., Brent, R., Kingston, R.E., Moore, D.D., Siedman, J.G., Smith, J.A., Struhl, K. (eds.) (1987). Current Protocols in Molecular Biology. Wiley Interscience, New York. Vols. 1 and 2.

Balech, E. (1985). The genus Alexandrium or Gonyaulax of the tamarensis group. In : Anderson, D.M., White, A.W., Baden, D.G. (eds.) Toxic Dinoflagellates. Elsevier, New York, pp. 33 - 38.

Balech, E., Tangen, K. (1985). Morphology and taxonomy of toxic species in the tarmarensis group (Dinophyceae): Alexandrium excavatum (Braarud) comb. nov. and Alexandrium ostenfeldii (Paulsen) comb. nov. Sarsia 70: 333-343.

Cembella, A.D., Sullivan, J.J., Boyer, G.L., Taylor, F.J.R., Andersen, R.J. (1987). Variation in paralytic shellfish toxin composition within the Protogonyaulax tamarensis/catenella species complex: red tide dinoflagellates. Biochem.Syst.and Ecol. 15: $171-186$.

Cembella, A.D., Taylor, F.J.R. (1986). Electrophoretic variability within the Protogonyaulax tamarensis/catenella species complex: pyridine linked dehydrogenases. Biochem.Syst.and Ecol. 14: 311-323.

Cembella, A.D., Taylor, F.J.R., Therriault, J.-C. (1988). Cladistic analysis of electrophoretic variants within the toxic dinoflagellate genus Protogonyaulax. Botanica Marina 31: 39-51.

Curran, J., Baillie, D.L., Webster, J.M. (1985). Use of genomic DNA restriction fragment length differences to identify nematode species. Parasitol. 90: 137-144.

Destombe, C., Cembella, A.D., Murphy, C.A., Ragan, M.A. (1992). Nucleotide sequence of the $18 \mathrm{~S}$ ribosomal RNA genes form the marine dinoflagellate Alexandrium tamarense (Gonyaulacales, Dinophyta). Phycologia 31: 121-124. 
Distel, D.L., DeLong, E.F., Waterbury, J.B. (1991). Phylogenetic characterization and in situ localization of the bacterial symbiont of shipworms (Teredinidae: Bivalvia) by using $16 \mathrm{~S}$ rRNA sequence analysis and oligonucleotide probe hybridization. Appl. Environ. Microbiol. 57:2376-2382.

Erlich, H.A., Gelfland, D., Sninsky, J.J. (1991). Recent advances in the polymerase chain reaction. Sci. 252: 1643-1651.

Field, K.G., Olsen, G.J., Lane, D.J., Giovannoni, S.J., Ghiselin, M.T., Raff, E.C., Pace, N.R., R.A. Raff. (1988). Molecular phylogeny of the animal kingdom. Sci. 239:748-753.

Gobel, U.B., Geiser, A., Stanbridge, E.J. (1987). Oligonucleotide probes complementary to variable regions of ribosomal RNA discriminate between Mycoplasma species. J. Gen. Microbiol. 133:1969-1974.

Goff, L.J., Coleman, A.W. (1988). The use of plastid DNA restriction endonuclease patterns in delineating red algal species and populations. J. Phycol. 24: 357-368.

Hallegraeff, G., Bolch, C.J. (1991). Transport of toxic dinoflagellate cysts via ship's ballast water. Mar.Poll.Bull. 22: 27-30.

Hallegraeff, G., Bolch, C.J., Blackburn, S.I., Oshima, Y. (1991). Species of the toxigenic dinoflagellate genus Alexandrium in southeastern Australian waters. Botanica Marina 34: 575-587.

Hallegraeff, G., and Bolch, C.J. (1992). Transport of toxic dinoflagellate cysts via ship's ballast water: implications for plankton biogeography and aquaculture. J. Plankton Res. 14: 1067-1084.

Hayhome, B.A., Anderson, D.M., Kulis, D.M., Whitten, D.J. (1989). Variation among congeneric dinoflagellates from the northeastern United States and Canada I. Enzyme electrophoresis. Mar. Biol. 101: 427-435.

Lenaers, G., Scholin, C. A., Bhaud, Y., Saint-Hilaire, D., Herzog, M. (1991). A molecular phylogeny of dinoflagellate protists (Pyrrhophyta) inferred from the sequence of the 24S rRNA divergent domains D1 and D8. J. Mol. Evolu. 32:53-63. 
Levy, M., Romao, J., Marchetti, M.A., Hamer, J.E. (1991). DNA fingerprinting with a dispersed repeated sequence resolves pathotype diversity in the rice blast fungus. The Plant Cell 3: 95-102.

McCutchan, T.F., de la Cruz, V.F., Lal, A.A., Gunderson, J.H., Elwood, H.J., Sogin, M.L. (1988). Primary sequences of two small subunit ribosomal RNA genes from Plasmodium falciparum. Molec. Biochem. Parasitol. 28: 63-68.

Moody, M.D. (1989). DNA analysis in forensic science. BioScience 39: 31-36.

Olsen, G.J., Lane, D.J., Giovannoni, S.J., Pace, N.R., Stahl, D.A. (1986). Microbial evolution: a ribosomal RNA approach. Ann. Rev. Microbiol. 40:337-365.

Prakish, A., Medcof, J.C., Tennant, A.D. (1971). Paralytic shellfish poisoning in eastern Canada. Bulletin of the Fisheries Research Board of Canada 177: 87 pp.

Rowan, R., Powers, D.A. (1991). A molecular genetic classification of zooxanthellae and the evolution of animal-algal symbioses. Sci. 251: $1348-1351$.

Saiki, R.K., Gelfand, D.H., Stoffel, S., Scharf, S.J., Higuchi, R., Horn, G.T., Mullis, K.B., Erlich, H.A. (1988). Primer-directed enzymatic amplification of DNA with a thermostable DNA polymerase. Science 239:487-491.

Sako, Y. (1992). Molecular definition and detection of toxic-harmful phytoplankton species. In: Smayda, T.J., Shimizu, Y. (eds.) Fifith international conference on toxic marine phytoplankton. Elsevier, New York (in press).

Sako, Y., Kim, C.H., Ninomiya, H., Adachi, M., Ishida, Y. (1990). Isozyme and cross analysis of mating populations in the Alexandrium catenella/tamarense species complex. In: Graneli, E., Sundstrom, B., Edler, L., Anderson, D.M. (eds) Toxic Marine Phytoplankton. Elsevier, New York, pp. 320-323. 
Scholin, C.A. and D.M. Anderson (1992). Population analysis of toxic and nontoxic Alexandrium species using ribosomal RNA signature sequences. In: Smayda, T.J., Shimizu, Y. (eds.) Fifith international conference on toxic marine phytoplankton. Elsevier, New York (in press).

Scholin, C.A., Anderson, D.M., Sogin, M. (submitted). The existence of two distinct small-subunit rRNA genes in the toxic dinoflagellate Alexandrium fundyense (Dinophyceae). J.Phycol.

Sogin, M.L. (1990). Amplification of ribosomal RNA genes for molecular evolution studies. In : Innis, M.A., Gelfand, D.H., Sninsky, J.J., White, T.J. (eds.). PCR protocols: A Guide to Methods and Applications. Academic Press, pp 307-314.

Sogin, M.L., Elwood, H.J., Gunderson, J.H. (1986). Evolutionary diversity of eukaryotic small-subunit rRNA genes. Proc. Natl. Acad. Sci. U.S.A 83:1383-1387.

Stahl, D.A., Flesher, B., Mansfield, H.R., Montgomery, L. (1988). Use of phylogenetically based hybridization probes for studies of ruminal microbial ecology. Appl. Environ. Microbiol. 54:10791084.

Steidinger, K.A. (1990). Species of the tamarensis/catenella group of Gonyaulax and the fucoxanthin derivative-containing Gymnodiniods. In: Graneli, E., Sundstrom, B., Edler, L., Anderson, D.M. (eds) Toxic Marine Phytoplankton. Elsevier, New York, pp. 11-16.

Steidinger, K.A., and Moestrup, Ø. (1990). The taxonomy of Gonyaulax, Pyrodinium, Alexandrium, Gessnerium, Protogonyaulax and Goniodoma. In: Graneli, E., Sundstrom, B., Edler, L., Anderson, D.M. (eds) Toxic Marine Phytoplankton. Elsevier, New York, pp. 522-523.

Taylor, F.J.R. (1984). Toxic dinoflagellates: taxonomic and biogeographic aspects with emphasis on Protogonyaulax. In: Ragelis, E.P. (ed.) Seafood Toxins. Amer. Chem. Soc. Symp. Series No. 262, Washington, D.C. pp. 77-97. 
Taylor, F.J.R. (1985). The taxonomy and relationships of red tide dinoflagellates. In : Anderson, D.M., White, A.W., Baden, D.G. (eds) Toxic Dinoflagellates. Elsevier, New York, pp. 11-26.

Taylor, F.J.R. (1990). Red tides, brown tides and other harmful algal blooms: a view into the 1990's. In: Graneli, E., Sundstrom, B., Edler, L., Anderson, D.M. (eds) Toxic Marine Phytoplankton. Elsevier, New York, pp. 527-533.

Wetton, J.H., Carter, R.E., Parkin, D.T., Walters, D. (1987). Demographic study of a wild house sparrow population by DNA fingerprinting. Nature 327: 147-149. 


\section{Chapter 3}

\section{Identification of Group- and Strain-Specific Genetic Markers For Globally Distributed Alexandrium (Dinophyceae) Species.}

\section{Sequence Analysis of a Fragment of the Large-Subunit Ribosomal RNA Gene}




\section{ABSTRACT}

A fragment of the large-subunit ribosomal RNA gene (LsrDNA) from the marine dinoflagellates Alexandrium tamarense (Lebour)

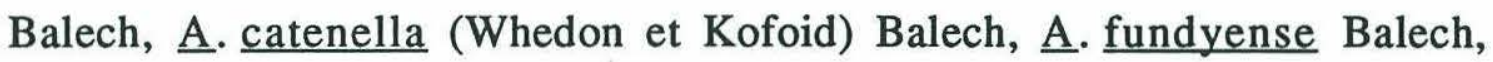
$\underline{A}$. affine (Fukuyo et Inoue) Balech, $\underline{A}$. minutum Halim, $\underline{A}$. lusitanicum Balech and $\underline{A}$. andersoni Balech have been cloned and sequenced in order to assess the organisms' inter- and intraspecific relationships. Cultures represent isolates from North America, Western Europe, Thailand, Japan, Australia and the ballast water of several cargo vessels, and include both toxic and non-toxic strains. Parsimony analyses revealed eight major classes of sequences, or "ribotypes," indicative of both species- and strain-specific genetic markers. Five ribotypes subdivide members of the "․․ tamarense/catenella/ fundyense species complex," but do not correlate with morphospecies designations; morphological features are less specific indicators of these organisms' relationships than are LsrDNA sequences. However, strains of $\underline{\mathrm{A}}$. tamarense/catenella/fundyense can be indicative of particular regional populations: representatives collected from the same geographic region appear the most similar, regardless of morphotype, whereas those from geographically-separated populations are more divergent even when the same morphospecies are compared. Contrary to this general pattern, $\underline{\mathrm{A}}$. $\underline{\text { tamarense }}$ and $\underline{\mathrm{A}}$. catenella from Japan were found to be exceptionally heterogeneous, displaying sequences nearly identical to those of Australian, North American and Western European isolates. This diversity, at least in part, may stem from an introduction of $\underline{A}$. tamarense to Japan from 
genetically-distinct source populations. The three remaining ribotypes were associated with cultures that clearly differ

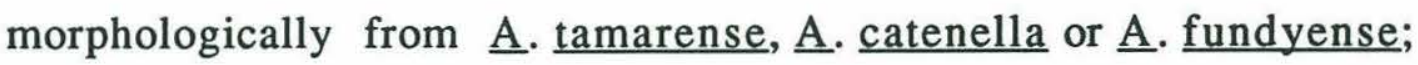
these distinct sequences are typified by: 1) $\underline{A}$. affine; 2) $\underline{A}$. minutum and $\underline{\mathrm{A}}$. $\underline{\text { lusitanicum; }}$ and, 3) $\underline{\mathrm{A}}$. andersoni. LsrDNAs from $\underline{\mathrm{A}}$. minutum and $\underline{\mathrm{A}}$. $\underline{\text { lusitanicum }}$ are indistinguishable, but differ from both $\underline{\mathrm{A}}$. andersoni and $\underline{\mathrm{A}}$. affine. An isolate's ability to produce toxin, or lack thereof, is consistent within LsrDNA terminal taxa. Results of the LsrDNA sequence analysis are in complete agreement with conclusions from a previous study using a restriction fragment length polymorphism (RFLP) assay of small-subunit rRNA genes (SsrDNAs), but LsrDNA sequences are finer-scale species and population indicators.

Previous attempts to correlate Alexandrium tamarense/ catenella/fundyense morphospecies with groups defined by isozyme electrophoretic and chemtaxonomic characteristics have resulted in conflicting conclusions; in some cases groups defined by morphotype are equivalent to those defined by biochemical characteristics, and in other cases they are not. Sequence analysis of rDNA offers an explanation for these confusing results: A. tamarense/catenella/ fundyense exist as a series of genetically-distinct populations, not three genetically-distinct morphospecies. A possible explanation for this is that $\underline{\mathrm{A}}$ tamarense/catenella/fundyense evolved from a common ancestor that included, or gave rise to, multiple morphotypes. 


\section{INTRODUCTION}

A central concern in many on-going studies of the taxonomy, biogeography, population dynamics and toxigenesis of marine dinoflagellates within the Alexandrium (=Protogonyaulax Taylor; Steidenger and Moestrup 1990) genus is the underlying genetic variability of this diverse group. This is especially true for the $\underline{A}$. tamarense, $\underline{\mathrm{A}}$. $\underline{\text { catenella }}$ and $\underline{\mathrm{A}}$. $\underline{\text { fundyense }}$ "species complex", a group of closely-related organisms found in many coastal regions of the world (Taylor '1984, Balech 1985). Researchers have long agreed that the conserved morphological features of these species belie a largely unexplored, genetic diversity. However, disagreement remains as to how this diversity correlates with morphospecies designations, and whether the morphotypes actually represent "true species" or a continuum of closely-related strains (Taylor 1985, Cembella et al. 1987, Hayhome et al. 1989, Sako submitted, Sako et al. 1990).

This debate is not only concerns the semantics of taxonomy, but also the means of classifying and distinguishing between different regional populations. Both debates must be settled if the global population structure of Alexandrium species is to be fully appreciated and hypotheses concerning their suspected dispersal critically addressed (Anderson 1989, Hallegraeff et. al 1991, Hallegraeff and Bolch 1991 and 1992, Scholin and Anderson 1992). In an effort to identify genetic markers applicable to these needs, sequences of genomic small-subunit (Ss) and large-subunit (Ls) 
ribosomal RNA (rRNA) genes (rDNAs) from a variety of Alexandrium species and populations, with particular emphasis on the $\underline{A}$. tamarense/catenella/fundyense group, have been compared.

A restriction fragment length polymorphism (RFLP) analysis of SsrDNAs from Alexandrium tamarense, $\underline{A}$. catenella, $\underline{A}$. fundyense, $\underline{A}$. affine, $\underline{A}$. minutum, $\underline{\text { A. lusitanicum }}$ and $\underline{A}$. $\underline{\text { andersoni isolated from }}$ many regions of the world revealed distinctive genetic characteristics which delineate Alexandrium species, and populations (strains) of individual species (Chapt. 2). Here, those observations are extended using detailed sequence analysis of the 5 ' portion of the LsrDNAs from a subset of those cultures examined with the RFLP technique. The particular region of LsrDNA chosen encompasses the so-called "D1" and "D2" hypervariable domains, some of the most rapidly evolving portions of eukaryotic rDNA (Mitchot et al. 1984, Mitchot and Bachellerie 1987, Lenaers et al. 1989, Lenaers et al. 1991).

\section{MATERIALS and METHODS}

Cultures used in this study (Table 1) represent a variety of Alexandrium morphospecies, and some of their globally-distributed populations. All were maintained in $\mathrm{f} / 2$ medium as modified and described by Anderson et al. (1984). Total nucleic acids from each culture were isolated, quantified and stored as described (Chapt. 2). 
Table 1. Strain numbers, species designations, isolation locales, toxicity, number of LsrDNA clones isolated and sequenced, length of PCR-amplified LsrDNA fragment and sources of Alexandrium cultures.

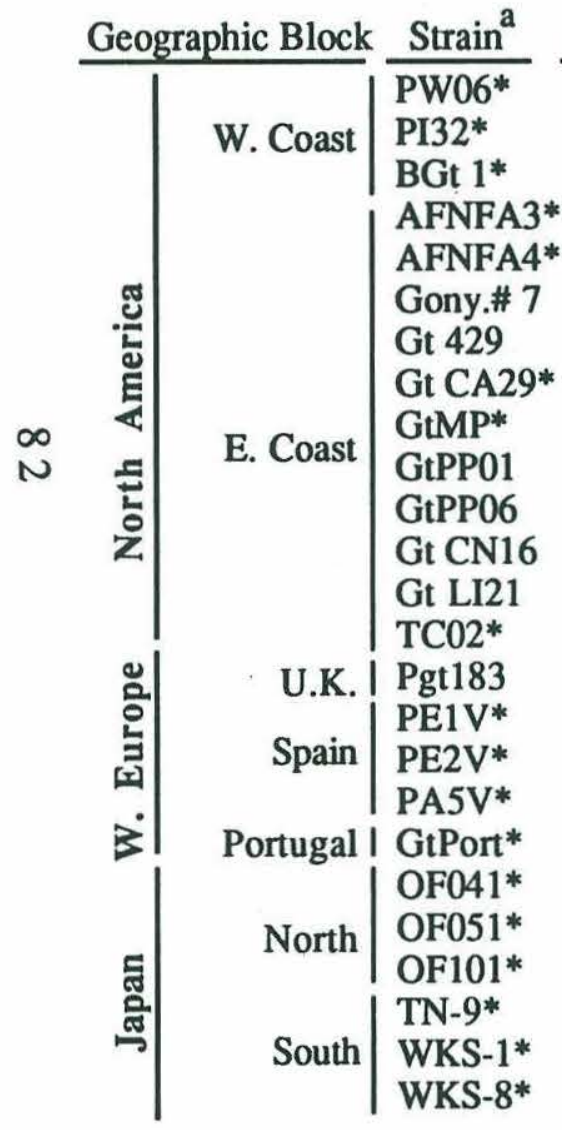

spp. Designation Isolation Locale

A. tamarense Port Benny, Alaska

A. fundyense Porpoise Isl., Alaska

A. catenella Russian River, CA

A. fundyense Newfoundland

A. tamarense Newfoundland

A. fundyense

A. fundyense

A. fundyense

A. fundyense

A. tamarense

A. tamaense

A. tamarense

A. tamarense

A. andersoni

A. tamarense

A. tamarense

A. tamarense

A. affine

A. lusitanicum

A. tamarense

A. tamarense

A. catenella

A. catenella

A. tamarense

A. catenella
Bay of Fundy

Ipswitch Bay, MA

Cape Ann, MA

Orleans, MA

Falmouth, MA

Falmouth, MA

Groton, CN

Babylon, NY

Eastham, MA

Plymouth,U.K.

Galicia, Spain

Galicia, Spain

Galicia, Spain

Portugal

Ofunato Bay, Japan

Ofunato Bay, Japan

Ofunato Bay, Japan

Tanabe Bay, Japan

Tanabe Bay, Japan

Tanabe Bay, Japan

\begin{tabular}{|c|c|c|}
\hline Toxic? & $\begin{array}{l}\text { \#LsrDNA Clones } \\
\text { Isolated }^{\text {c }}\end{array}$ & $\begin{array}{l}\text { Length ofLsrDN } \\
\text { Fragment }\end{array}$ \\
\hline yes & 5,7 & 668 \\
\hline yes & 7 & 668 \\
\hline yes & 10 & 668 \\
\hline yes & 8 & $666 / 668$ \\
\hline yes & 11 & $666 / 668$ \\
\hline yes & 14 & $666 / 668$ \\
\hline yes & 13 & $666 / 668$ \\
\hline yes & 7 & $666 / 668$ \\
\hline yes & 12 & $666 / 668$ \\
\hline yes & 13 & $666 / 668$ \\
\hline yes & 10 & $666 / 668$ \\
\hline yes & 9 & $666 / 668$ \\
\hline yes & 12 & $666 / 668$ \\
\hline no & 11 & 661 \\
\hline no & 7 & 669 \\
\hline nо $\Psi$ & 12 & 669 \\
\hline no & 14 & 669 \\
\hline yes & 12 & 676 \\
\hline yes & 9 & 671 \\
\hline yes & 13 & $666 / 668$ \\
\hline yes & 10 & $666 / 668$ \\
\hline yes & 10 & 669 \\
\hline yes & 10 & 669 \\
\hline no & 12 & 669 \\
\hline yes & 10 & 669 \\
\hline
\end{tabular}

Culture S. Hall

S. Hall

D. Anderson

D. Anderson

D. Anderson

A. White

C. Martin

D. Anderson

D. Anderson

D. Anderson

D. Anderson

D. Anderson

D. Anderson

D. Anderson

M. Taylor

I. Bravo

I. Bravo

I. Bravo

L. Provasoli

Y. Sako

Y. Sako

Y. Sako

Y. Sako

M. Kodama

M. Kodama 


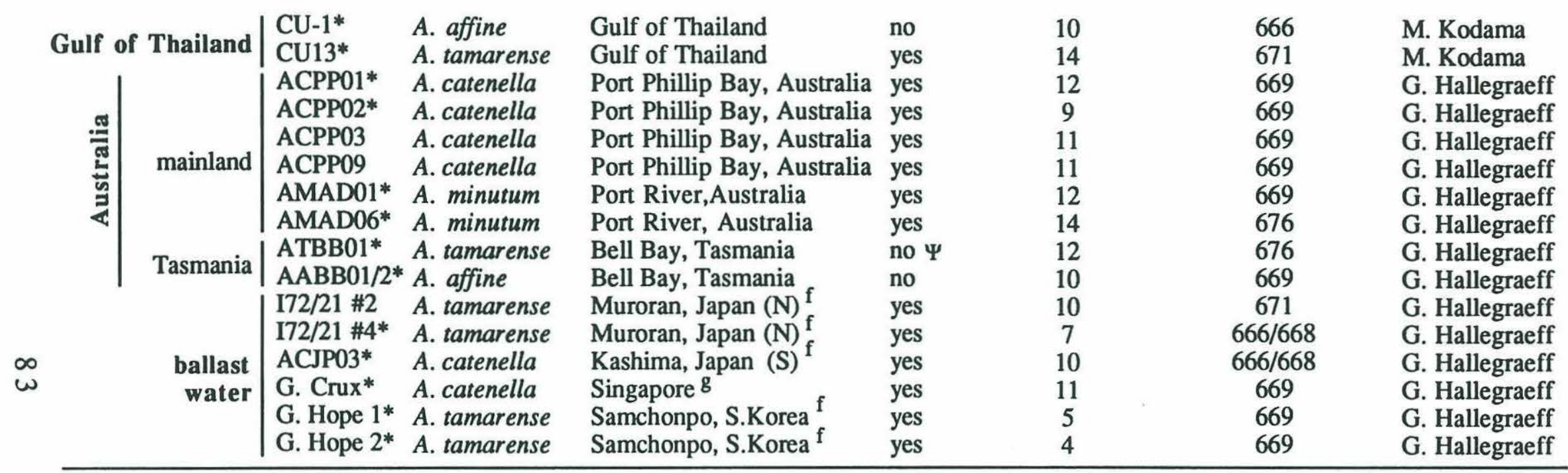

a) strain listings currently used in the D.M. Anderson culture collection; "*" indicates isolates whose sequences were used to construct the phylogenetic trees (Figs. 3 and 4); all cultures are clonal except for BGt 1, GtMP, PE1 V, PE2V, G. Hope 1 and G. Hope 2

b) determined by mouse bioassay and/or HPLC analysis; "nd" indicates "not determined;" " $\Psi$ ' may contain trace amounts of toxin (D.Kulis, pers. comm.)

c) number of LsrDNA fragment clones isolated from a given culture and pooled prior to sequencing; LsrDNA fragments from PW06 were cloned on two separate occasions

d) sequence length (base pairs) of the PCR-amplified LsrDNA fragment; cultures harboring the 590-591 heterogeneity are denoted "666/668"

e) individuals who supplied the culture

f) presumed origin (Hallegraeff and Bolch, 1992)

g) hailing port of vessel - origin of ballast water uncertain (Hallegraeff and Bolch, 1992) 
Polymerase Chain Reaction (PCR) Amplifications

Approximately 700 base pairs of the LsrDNAs were PCRamplified (Saiki et al, 1988) using primers targeted towards conserved elements at positions 24-45 ["D1R" (forward); 5'ACCCGCTGAATTTAAGCATA3'] and 733-714 ["D2C" (reverse); 5'CCTTGGTCCGTGTTTCAAGA3'], relative to the Prorocentrum micans LsrRNA (Lenaers et al. 1989). This fragment encompasses the evolutionarily variable domains D1 and D2 (Mitchot et al. 1984, Lenaers et al. 1989). Amplifications were carried out in duplicate or triplicate as previously described (Chapt. 2), except that the final concentration of each primer was $0.1 \mu \mathrm{M}$ and primer annealing was at $45{ }^{\circ} \mathrm{C}$. Following amplification, replicate reactions from a given culture were pooled, purified, concentrated and stored as noted (Chapt. 2).

\section{Cloning of LsrDNA}

LsrDNA fragments were cloned using Invitrogen's T/A cloning kit (cf. Holton et al. 1991, Marchuck et al. 1991) according to the recommendations of the manufacturer. Generally, 16 bacterial clones potentially containing plasmids with a LsrDNA insert (i.e., white colonies) were screened for each dinoflagellate examined. In addition, a bacterial clone known to contain a plasmid without an insert (i.e., blue colony) was also processed. Each bacterial clone was inoculated into $2 \mathrm{~mL}$ of $\mathrm{L}$ Broth (Ausubel et al., 1987) containing 50 $\mu \mathrm{g} / \mathrm{mL}$ kanamycin and was grown overnight at $37{ }^{\circ} \mathrm{C}$ with vigorous 
shaking. Plasmid preparations for each clone were carried out with $1.5 \mathrm{~mL}$ of the overnight culture using the modified Birnboim procedure as described by Ausbel et al. (1987). The remaining 0.5 $\mathrm{mL}$ of culture was kept at $4{ }^{\circ} \mathrm{C}$ during the plasmid isolation and screening procedure. Initial plasmid precipitates were rinsed in 1 $\mathrm{mL}$ of ice-cold $80 \% \mathrm{EtOH}$ for at least $30 \mathrm{~min}$ at $-20{ }^{\circ} \mathrm{C}$ and spun at $12,000 \mathrm{xg}$ for $10 \mathrm{~min}$ in a cold $\left(\sim 4{ }^{\circ} \mathrm{C}\right)$ Sorvall microfuge.

Supernatants were removed by vacuum aspiration and the pellet air dried for 5-10 min. Following this, the plasmids were resuspended in $50 \mu \mathrm{L}$ TE (7.5) + DNase-free RNase A [1 mL TE + $10 \mu \mathrm{L} 10 \mathrm{mg} / \mathrm{mL}$ RNase A (supplied and prepared as directed by Sigma)]. After removing an aliquot for restriction digestion (see below), the plasmids were stored at $-20{ }^{\circ} \mathrm{C}$.

Selection of LsrDNA Clones

One uL of each resuspended plasmid was digested with HindIII (New England Biolabs) in a final volume of $10 \mu \mathrm{L}$. Products of the digestions were resolved on $0.7 \%$ agarose gels using 1 XTBE buffer (Ausubel et al. 1987). HindIII cleaves once within the cloning vector and had no sites within any of the LsrDNA fragments examined. Clones containing a single LsrDNA insert were identified by comparing their mobility to size standards and the negative control (i.e., blue clone) plasmid. Positive plasmid clones were stored separately at $-20{ }^{\circ} \mathrm{C}$. The remaining portion of corresponding bacterial cultures were cryo-preserved by addition of an equal volume of freeze down buffer $[1 \%(\mathrm{w} / \mathrm{v})$ yeast extract, $10 \%(\mathrm{v} / \mathrm{v})$ 
dimethylsulfoxide, $10 \%$ (v/v) glycerol, $0.2 \mathrm{M} \mathrm{K} \mathrm{K}_{2} \mathrm{HPO}_{4} / \mathrm{NaH}_{2} \mathrm{PO}_{4}$ $(\mathrm{pH} 7.0)]$ and storage at $-80{ }^{\circ} \mathrm{C}$.

Sequencing of LsrDNA Clones

Several precautions were taken in order to minimize sequencing errors: 1) two to three replicate PCR amplifications were pooled prior to cloning; 2) multiple LsrDNA clones from each Alexandrium isolate ${ }^{1}$ were pooled prior to sequencing to gauge the homogeneity of the products and identify the locations of ambiguities or length heterogeneities; and, 3) both strands of the cloned molecules were sequenced to aid the accuracy of the determinations (Sogin 1990). In some cases where heterogeneities and ambiguities were observed, individual clones from a given isolate were individually sequenced.

Template denaturation. Aliquots of each positive LsrDNA clone for a given dinoflagellate strain were pooled to yield a final volume of $120 \mu \mathrm{L}$ in a $1.5 \mathrm{~mL}$ microcentrifuge tube. The plasmid pool was denatured with the addition of $120 \mu \mathrm{L}$ of $0.6 \mathrm{~N} \mathrm{NaOH}$, gentle mixing and incubation at room temp for $5 \mathrm{~min}$. Denatured templates were neutralized and precipitated by adding $9 \mu \mathrm{L}$ of $2 \mathrm{M} \mathrm{NH}_{4} \mathrm{OAc}$ ( $\mathrm{pH}=4.5$ ) and $900 \mu \mathrm{L}$ of $100 \%$ ethanol (EtOH). This solution was vortexed, immediately divided among four separate $0.5 \mathrm{~mL}$ tubes $(\sim 290$ $\mu \mathrm{L} /$ tube) and chilled at $-20{ }^{\circ} \mathrm{C}$ for at least 2 hrs. Each tube contains

1 throughout this text, the term "clone" refers to a recombinant plasmid, whereas "isolate" refers to a specific laboratory culture of Alexandrium 
approximately $30 \mu \mathrm{L}(\sim 1 \mu \mathrm{g})$ of denatured plasmid, an amount empirically found to give excellent sequencing results. When analyzing single clones, $10-30 \mu \mathrm{L}$ of an individual plasmid preparation was used per sequencing reaction, denaturation and precipitation were carried out in a single $0.5 \mathrm{~mL}$ tube, and volumes of $\mathrm{NaOH}, \mathrm{NH}_{4} \mathrm{OAc}$ and $\mathrm{EtOH}$ were adjusted accordingly. Denatured plasmid precipitates were collected by centrifugation in a chilled $\left(4{ }^{\circ} \mathrm{C}\right)$ Sorvall microfuge at $12,000 \mathrm{xg}$ for $10-15 \mathrm{~min}$. Supernatant was discarded, and the pellet rinsed in $70 \% \mathrm{EtOH}$ for at least $30 \mathrm{~min}$. at $-20^{\circ} \mathrm{C}$. On the day plasmids were to be sequenced, the precipitate was once again collected by centrifugation, as much supernatant was removed as possible, and pellets were allowed to air dry, but not to completion. The tubes were then tightly capped and stored at $4{ }^{\circ} \mathrm{C}$ until needed.

All sequencing reactions were carried out using United States Biochemical (USB) Corp. Sequenase version 2.0 sequencing kit reagents and Amersham dATP $\left[\alpha^{35}\right.$ S label $(10 \mu \mathrm{Ci} / \mu \mathrm{L})$. The sequencing strategy is shown in Figure 1. Both strands of the LsrDNA inserts were sequenced using the amplification primers [D1R (forward) and D2C (reverse)], and two internal primers, "D1C" (reverse; 5'ACTCTCTTTTCAAAGTCCTT 3'; corresponds to Prorocentrum micans LsrRNA positions 388-369; ) and "D2Ra" (forward; 5'TGAAAAGGACTTTGAAAAGA3'; corresponds to $\underline{\mathrm{P}}$. micans LsrRNA positions 365-386; Lenaers et al. 1989). D2Ra replaced an earlier primer ["D2R" (forward; 5'CAAGTACCATGAGGGAAAGG3'; corresponds to $\underline{P}$. micans LsrRNA positions $345-364)$ ] that was used 
in pilot sequencing efforts; all sequences primed with D2R were repeated with D2Ra. "Forward" reactions give products whose sequence is rRNA-like, while "reverse" reactions give products whose sequence is the complement of the rRNA.

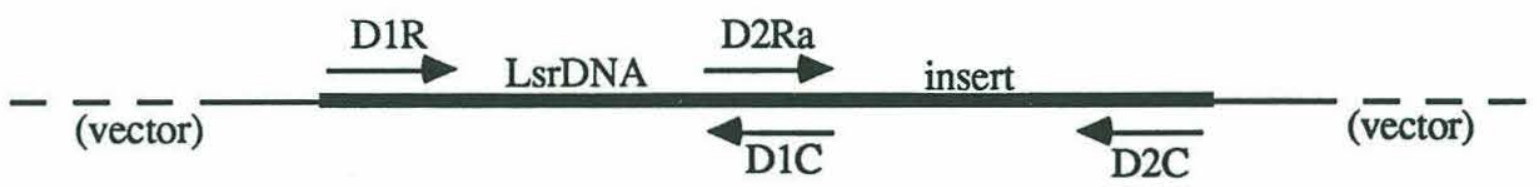

Figure 1. Sequencing strategy for LsrDNA clones. Thin and dashed line represents plasmid sequences; thick line represents the inserted LsrDNA fragment. Relative location of sequencing primers are shown; arrows indicate direction of sequence polymerization (Ls insert is depicted 5'-3').

Primer Hybridization and Preparation of Labelling Mix. The denatured, precipitated plasmid clones were resuspended with $8 \mu \mathrm{L}$ primer $(0.5 \mathrm{pmol} / \mu \mathrm{L}$ in $10 \mathrm{mM}$ TrisHCl $\mathrm{pH}=7.5)$ and $2 \mu \mathrm{L}$ reaction buffer (USB), mixed, and incubated for $\sim 10 \mathrm{~min}$ at $37^{\circ} \mathrm{C}$. During primer annealing, ice-cold labelling mix for 3 sequencing reactions was prepared by combining: $2.1 \mu \mathrm{L} \mathrm{ddH}_{2} \mathrm{O}, 3.0 \mu \mathrm{L} 100 \mathrm{mM}$ DTT (USB), $6.0 \mu \mathrm{L}$ labelling mix (USB; diluted 1:4 with $\mathrm{ddH}_{2} \mathrm{O}$ ), $3.0 \mu \mathrm{L}$ dATP $\left[\alpha^{35}\right.$ S $(10 \mu \mathrm{Ci} / \mu \mathrm{L}), 1.0 \mu \mathrm{L}$ Sequenase v 2.0 (USB) and $0.5 \mu \mathrm{L}$ pyrophosphatase (USB); Sequenase and pyrophosphatase were added immediately prior to the completion of the hybridization reactions. 
Labelling and termination reactions. $5 \mu \mathrm{L}$ of labelling mix was added to the $10 \mathrm{uL}$ hybridization reaction, mixed by gentle pipetting and incubated for $1 \mathrm{~min}$. at room temp. Afterwards, $3.5 \mu \mathrm{L}$ of this solution was added to $2.5 \mu \mathrm{L}$ of each ddNTP (USB), and allowed to incubate at $37 \mathrm{o}^{\circ}$ for $10 \mathrm{~min}$. Sequencing reactions were terminated by the addition of $4 \mu \mathrm{L}$ stop mix (USB). Typically, 3 sequencing reactions were carried out in quick succession with overlaps in their termination reactions. Reactions were stored no longer than several days at $-20{ }^{\circ} \mathrm{C}$ before polyacrylamide gel electrophoresis.

Sequencing Gel Electrophoresis

Products of the sequencing reactions were resolved on $6 \%$ polyacrylamide (19:1 acrylamide:bis-acrylamide), 8.3 M Urea, 1x TBE gels using a BioRad Sequigencell apparatus. In order to improve resolution of the bands, the top buffer chamber was filled with $0.5 \mathrm{x}$ TBE and the bottom chamber filled with 1x TBE. Gels were preelectrophoresed with a constant power setting until reaching $\sim 50{ }^{\circ} \mathrm{C}$. During the pre-electorphoresis, sequencing reactions were thawed on ice, heated to $80{ }^{\circ} \mathrm{C}$ for $3 \mathrm{~min}$. and immediately returned to ice. Approximately $2.5 \mu \mathrm{L}$ of each reaction was loaded per lane and run until the bromophenol blue dye had migrated roughly $1 / 3$ the length of the gel. Electrophoresis was then briefly terminated while $200 \mathrm{~mL}$ (1/2 volume) of $3 \mathrm{M} \mathrm{NaOAc}(\mathrm{pH} \mathrm{5.0)}$ was added to the bottom buffer chamber. Electrophoresis was resumed and the constant power setting adjusted as required to maintain a surface plate temperature of $\sim 50-55{ }^{\circ} \mathrm{C}$. Electrophoresis was terminated when the xylene 
cyanol dye front had migrated to within $10-12 \mathrm{~cm}$ from the bottom of the gel. Gels were fixed in $10 \%$ methanol $10 \%$ glacial acetic acid for $30 \mathrm{~min}$, dried onto Whatman $3 \mathrm{MM}$ paper at $80{ }^{\circ} \mathrm{C}$ for $45 \mathrm{~min}$ using a Sorvall sequencing gel dryer with applied vacuum, and then exposed to either XAR-5 or XRP-5 X-ray film (Kodak). Exposures ranging from overnight to 2 days were found to be optimal. A typical run yielded approximately 300-350 readable nucleotides.

Sequence Analysis

Sequence determinations for a given dinoflagellate culture were compiled using the editor function of PAUP 3.0 (Swofford 1991). Sequences from each isolate were then aligned with the help of conserved elements interspersed throughout the length of the molecules (Fig. 2). The alignment was subjected to a variety of phylogenetic analyses using heuristic methods (PAUP 3.0; Swofford 1991). The phylogenetic tree shown in Fig. 3 was constructed using the following parameters: all characters weighted equally; sequence gap=missing data; stepwise addition; closest addition sequence; 1 tree held at each step during stepwise addition; tree-bisectionreconnection (TBR) branch-swapping performed; MULPARS option in effect; steepest descent option not in effect; maxtrees $=200$; branches having maximum length zero collapsed to yield polytomies; topological constraints not enforced; trees unrooted; multi-state taxa interpreted as uncertainty; outgroup taxa defined as AMAD01, AMAD06, GtPort and TC02; and, ACCTRAN character state optimization. Bootstrap analysis (Felsenstein 1985; 500 rounds) of 
the alignment was also carried out with same parameters as above, except that maxtrees $=15$ per replicate bootstrap (Fig. 4).

\section{RESULTS}

Amplification, Cloning, Sequencing and Alignment of LsrDNA Fragments

Agarose gel electrophoresis of the PCR-amplified portion of the LsrDNAs typically revealed homogeneous products approximately $700 \mathrm{bp}$ in length. Direct cloning of these molecules yielded an average of 10 positive LsrDNA clones (range 4-14) for each Alexandrium isolate examined (Table 1). LsrDNAs cloned from different Alexandrium isolates vary slightly in length (Table 1). In some cases, the LsrDNAs from a single isolate also contained length heterogeneities and sequence ambiguities (Fig. 2; cf. Appendix C). The most dramatic example of length heterogeneities were found in

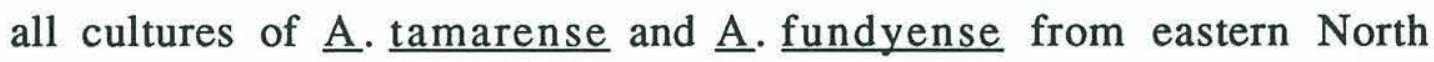
America, two Japanese $\underline{A}$. tamarense from Ofunato Bay (OF041 and OF051) and two ballast water $\underline{A}$. tamarense (I72/21\#2, I72/21\#4; Table 1). LsrDNA clones from these organisms display an identical two base pair length heterogeneity (TG deletion) at positions 590591 (Fig. 2). All isolates that harbor this heterogeneity contain at least two, distinct copies of the LsrRNA gene: those which carry the 590-591 TG deletion, and those that do not (Appendix C). Alexandrium fundyense from Newfoundland (AFNFA3 and AFNFA4) both contain another heterogeneity over positions 106-110 in 
addition to the 590-591 TG deletion. The LsrDNAs cloned from AFNFA3 have been denoted "AFNFA3.1" [identical to the reference sequence (PW06) at positions 106-110 and 590-591] and "AFNFA3.2" (vary from the reference sequence at positions 106-110 and 590-591; Fig. 2). The LsrDNAs cloned from AFNFA4 contain the same two variants, but are reported here as the AFNFA3.2-like sequence.

Sequences from thirty three Alexandrium strains were used in the phylogenetic analyses (Table 1). The proposed alignment is shown in Fig. 2. Since both variants of AFNFA3 were included (AFNFA3.1 and AFNFA3.2), a total of thirty four sequences were compared. Six eastern North American $\underline{A}$. tamarense/fundyense and one ballast water $\underline{A}$. tamarense (I72/21\#2) were excluded because the 590-591 deletion obscured sequencing ladders over the $3^{\prime}$ half of their LsrDNA clones. Nevertheless, partial sequences from these cultures made it clear that they are very similar to other eastern North American $\underline{A}$. tamarense/fundyense and the ballast water $\underline{\mathrm{A}}$. tamarense (I72/21\#4) whose sequences are fully resolved.

Sequences for the latter group were obtained by sequencing individual LsrDNA clones, or, in some cases, because the LsrDNA clones from an isolate were "clonally-biased" towards one of the two variants (Appendix C). Those organisms containing the 590-591 length heterogeneity that were incorporated into the final alignment are shown with the TG deletion (Fig. 2, denoted by "**") in order to identify them as cultures which share a common character. Two

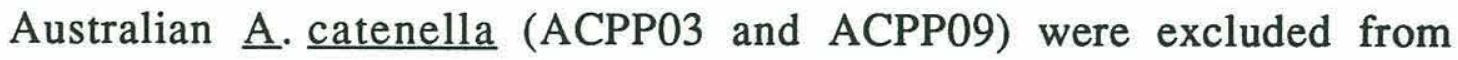


the final analysis since their sequences exhibited only minor differences from the other Australian A. catenella (ACPP01 and ACPP02; Appendix C).

Figure 2. (pages 94-100) Proposed LsrDNA sequence alignment for noted Alexandrium strains (see Table 1 for species designations and solation locales). Alignment position 1 corresponds to $\underline{\mathrm{P}}$. micans LsrDNA position 45 (Lenaers et al. 1989). PW06 (A. tamarense, Alaska) is used as the reference sequence; all equivalent positions are indicated by a period. Dashes represent inserted alignment gaps. Those organisms containing the 590-591 TG length heterogeneity are shown with the deletion, as denoted by "**;" these cultures also contain LsrDNAs that do not have this deletion. Two sequences for AFNFA3 (․ fundyense, Newfoundland) are shown: AFNFA3.1 is similar to PW06 at positions 106-110 and does not have the 590-591 TG deletion; AFNFA3.2 differs from PW06 at positions 106-110 and does harbor the 590-591 TG deletion. AFNFA4 (A. fundyense, Newfoundland) contains the same two sequences, but is shown here as the AFNFA3.2-like variant. Approximate boundaries of the D1 and D2 hypervariable domains are noted. Sequence ambiguities are reported using standard IUPAC nomenclature $(\mathrm{R}=\mathrm{A}$ or $\mathrm{G} ; \mathrm{Y}=\mathrm{C}$ or $\mathrm{T} ; \mathrm{M}=\mathrm{C}$ or $\mathrm{A} ; \mathrm{K}=\mathrm{G}$ or $\mathrm{T} ; \mathrm{W}=\mathrm{A}$ or $\mathrm{T}$ ). 


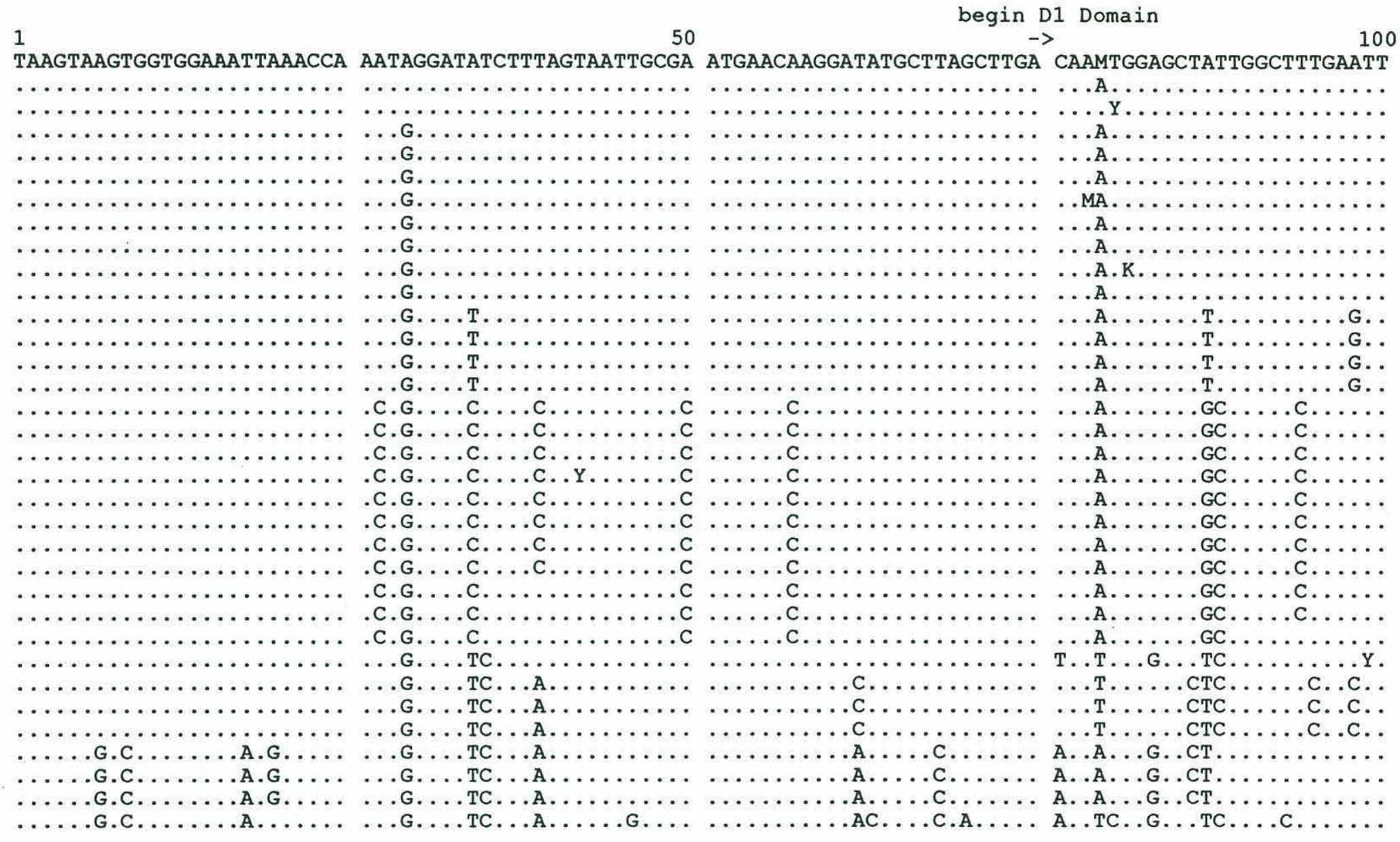


WKS 8

ATJP03
ACJP0 3

ACPP 01

ACPP 02

G. CRUX

GHOPE1

GHOPE2

ATBBO1

CU13

CU1

AABB01/2

PA5V

AMAD01

AMAD0 6

GTPORT

GTATTGTGGAATGTATTACCAACA GAGGTGCAGGTGCAGCCTATTGAA ATAAAGCGTCAATGAGGTGAGAAT CCTGTTTGTCATGTGCARCCCTTTG

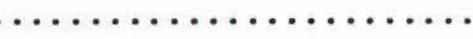

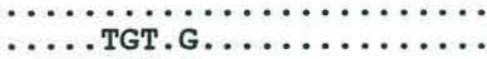

... TGT.G.

$\ldots \ldots \ldots \ldots \ldots \ldots \ldots \ldots \ldots \ldots$

a.

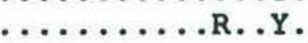

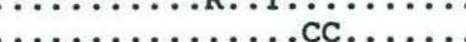

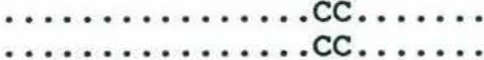

$\ldots \ldots \ldots \ldots \ldots \ldots$. $\ldots \ldots \ldots$

$\ldots \ldots \ldots \ldots$. . . . .

............

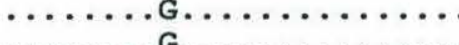

$\ldots \ldots \ldots$ G.............

..G.

G...................

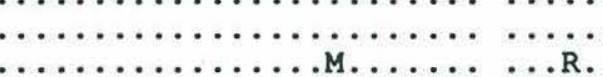

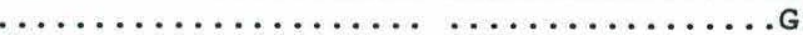

........G.

$\ldots \ldots \ldots \cdots$

. $\cdots \cdots \cdots \cdots \cdots$

M........

...

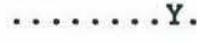

G.......

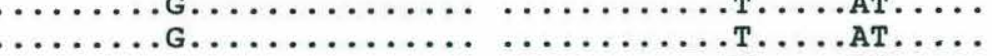

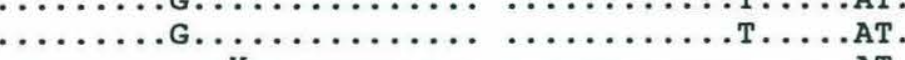

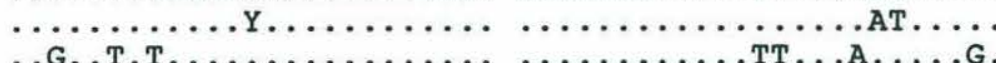

TT...A....G.

$\cdots$ T.T.

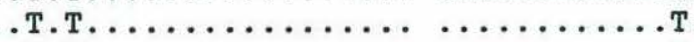

.... T. T.

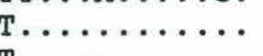

...T.T.

.G....TG

..... . . . . .

A.T.T.

G...TTG

. . . . . . . . . .

...T.T.

.G. . . TG

C..........

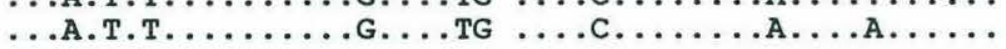

G.......

G.......

TC02

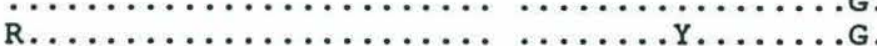

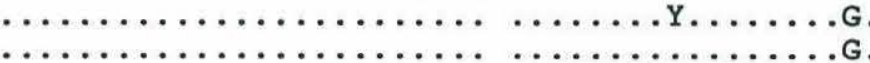

a.

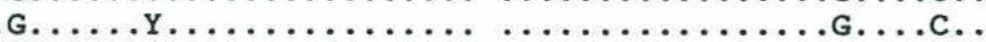

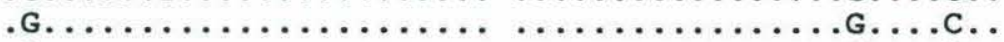

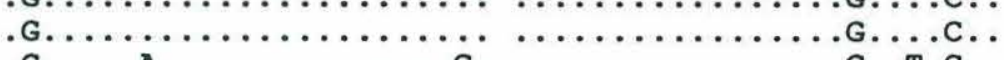

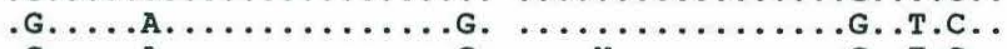

.G...A...........................

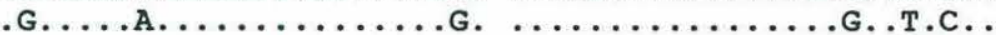

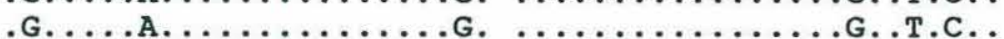

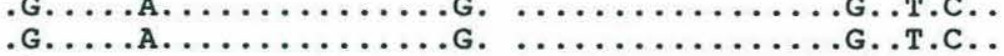

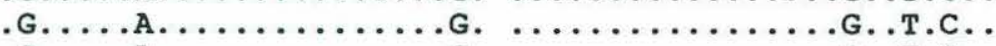

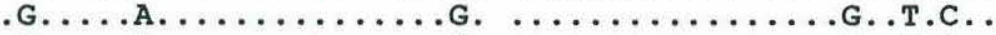

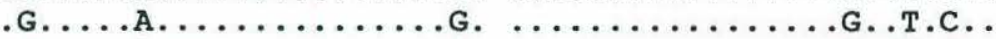

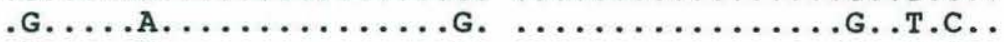

G...A. . . . . . .

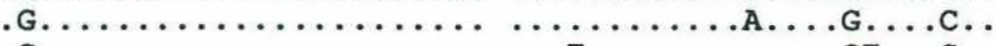

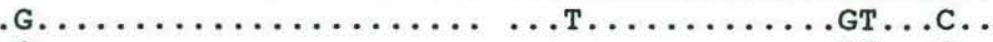

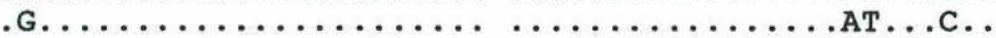

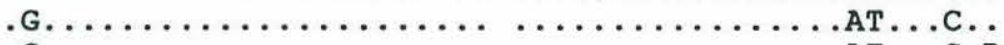

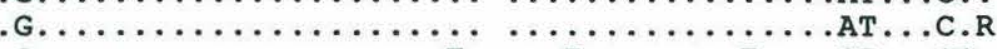

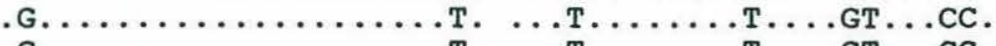

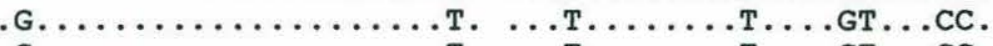

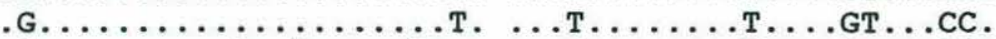

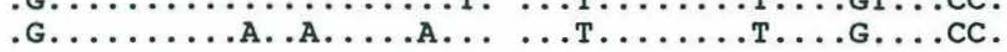




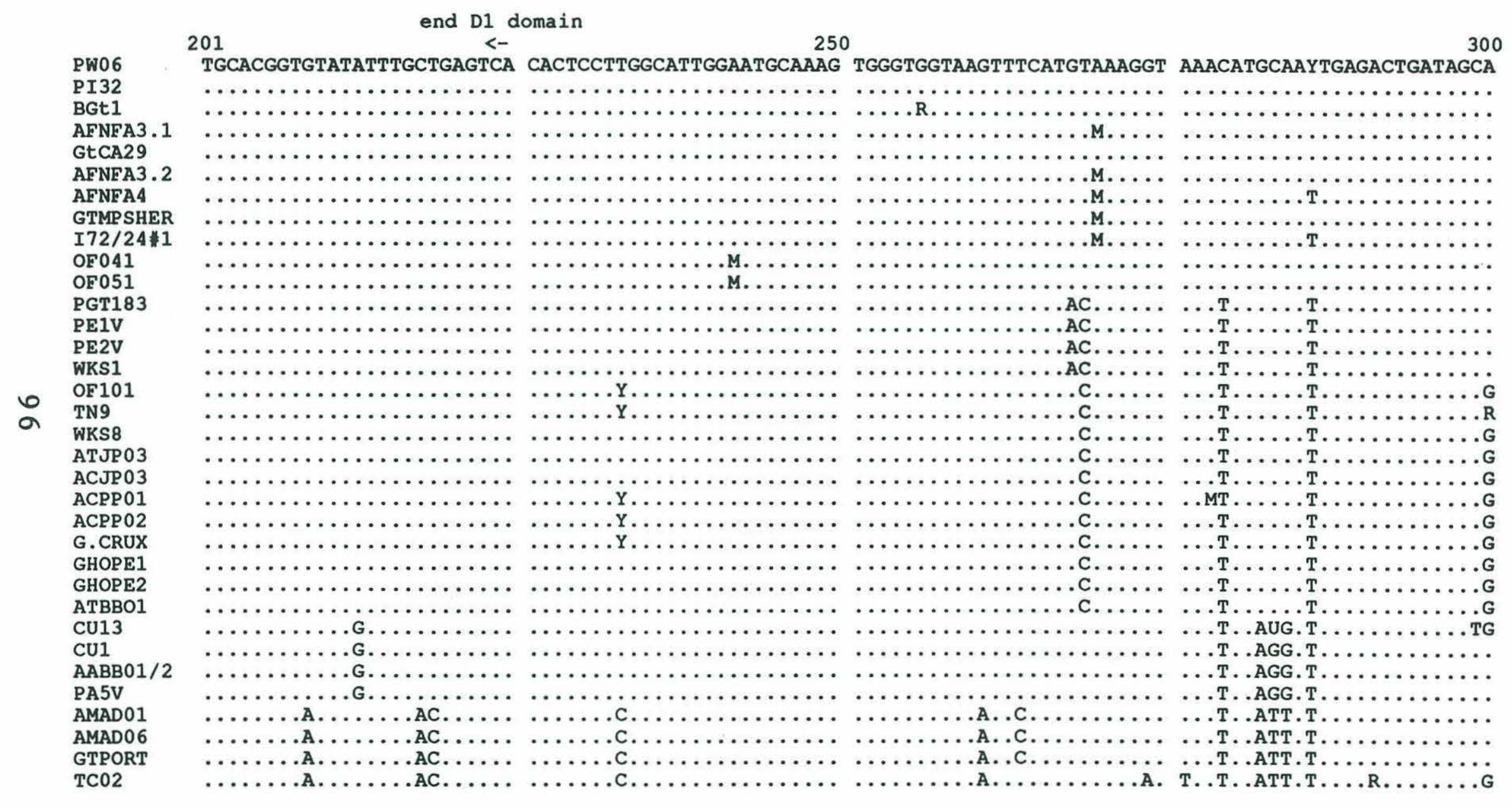


AMAD01

AMAD 06

GTPORT

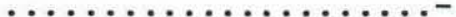

$\mathrm{TC} 02$ 
TTTGTGT-TTTGATAMATGTGTCTG GTG-TATGTGTGTGTGTTCC-TGTG

AFNFA

GTMPSHER

$I 72 / 24 \# 1$

OF041

OF051

PGT183

PE1V

PE2V

WKS1

OF 101

\section{TH.}

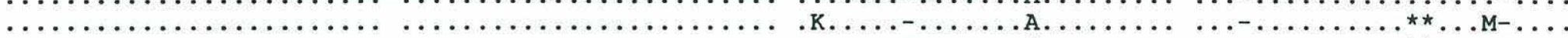

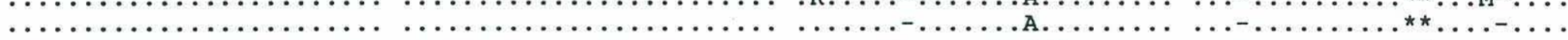

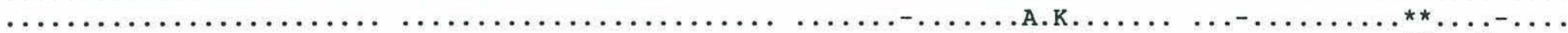

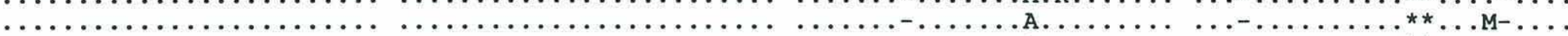

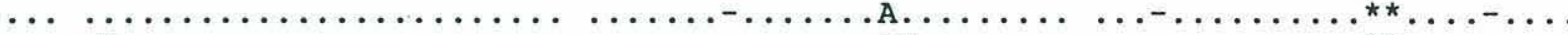

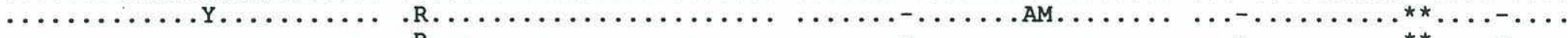

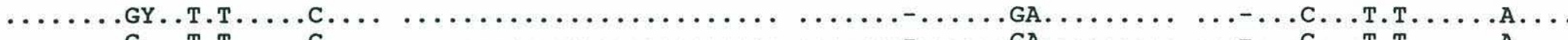

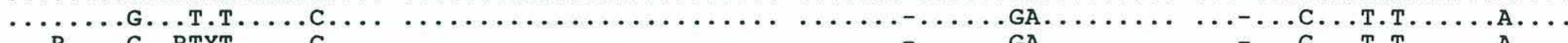

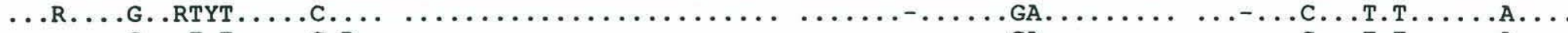

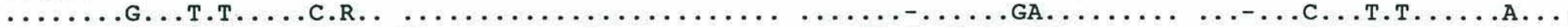

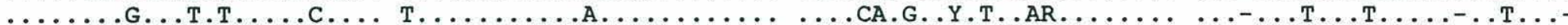

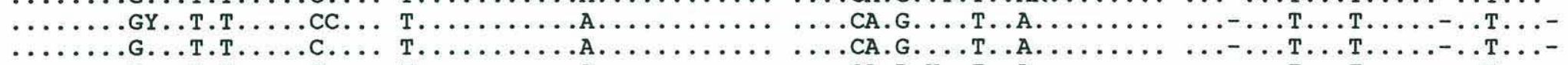

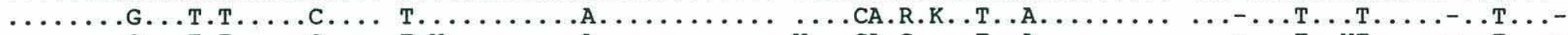

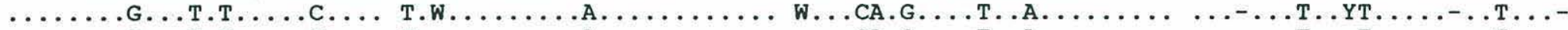

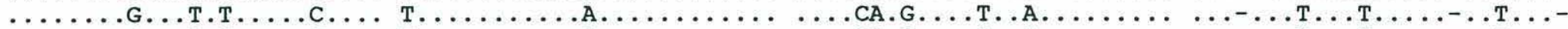

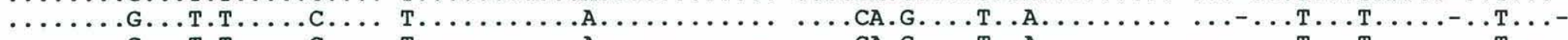

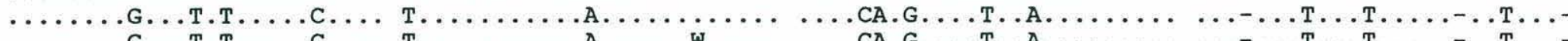

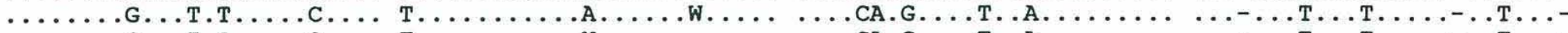

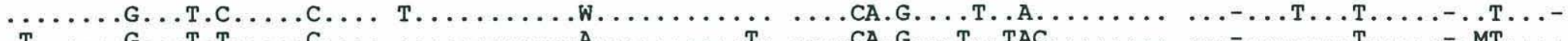

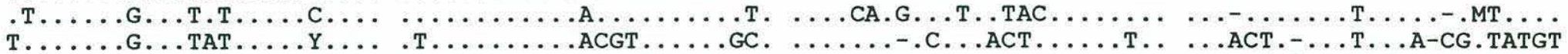

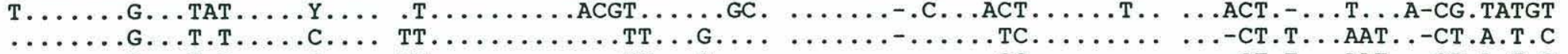

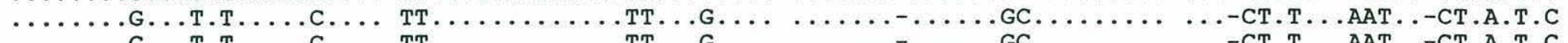

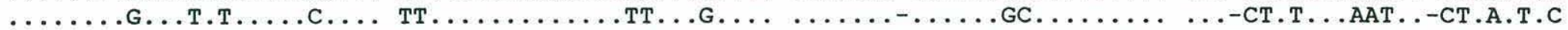

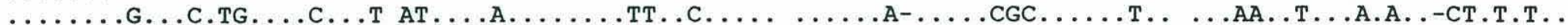

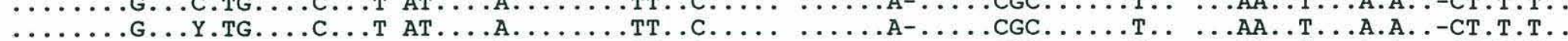

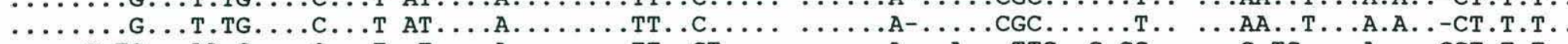

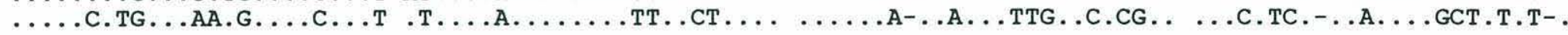




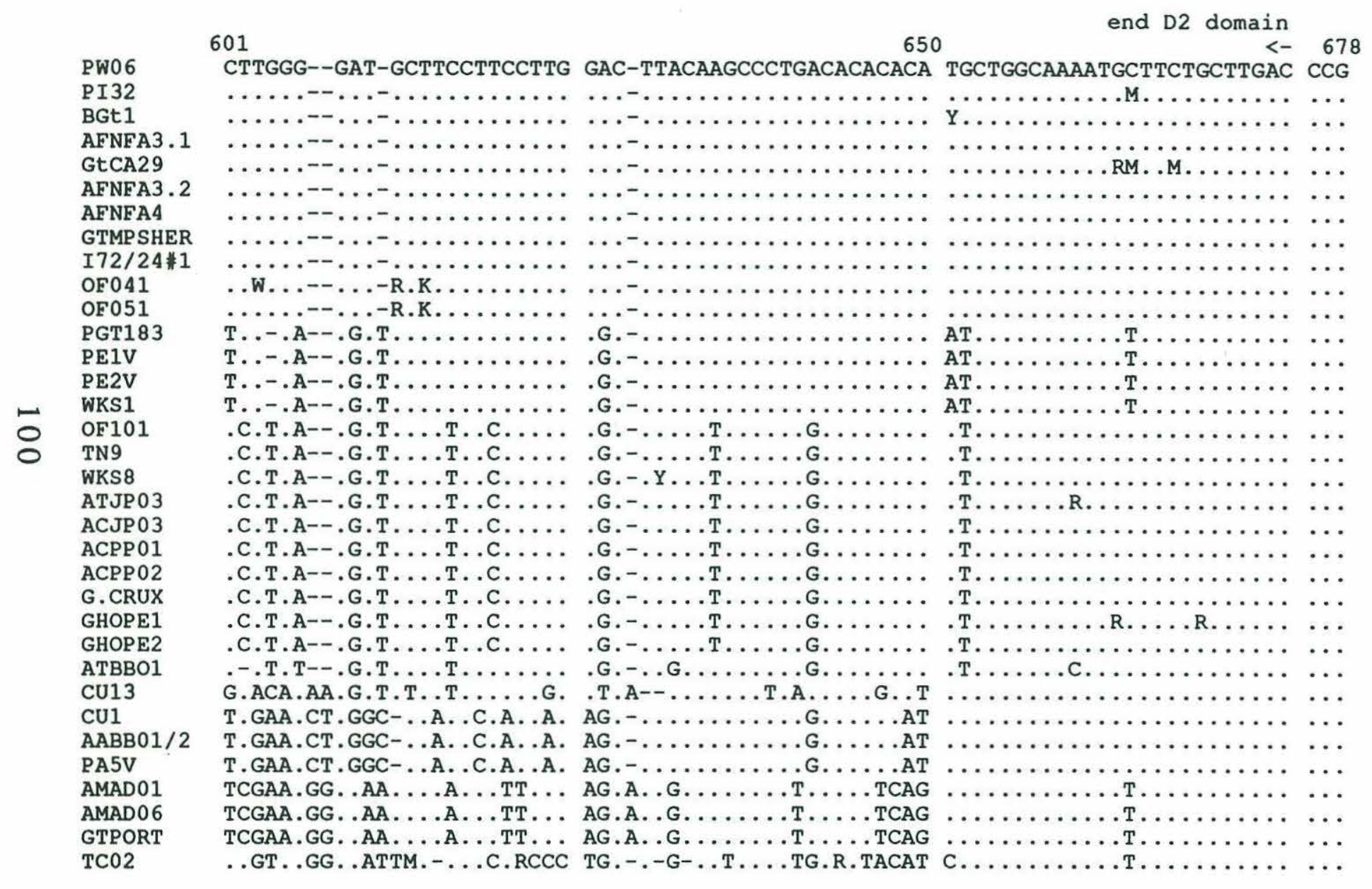


Phylogenetic Analyses of the Aligned LsrDNAs

Eight distinct classes of sequences, or "ribotypes," were found among the thirty three Alexandrium cultures compared (Fig. 3). The tree topology and significance of branching patterns were examined in several ways. First, PAUP outputs of "ensemble statistical indices" (Swofford 1991) were considered to gauge the "fit" of the sequence data and the tree topology. The tree shown in Fig. 3 has relatively high values of consistency indices, suggesting a high degree of congruence between the resolution of Alexandrium groups and their sequence characteristics (Swofford 1991, Wiley et al. 1991). Secondly, consensus trees were constructed to evaluate the Alexandrium groupings common among "rival" (i.e., equally parsimonious) trees found in the search (cf. Swofford 1990, Wiley et al. 1991). In all cases (strict, Adams and majority-rule) the consensus trees revealed the same associations between cultures as are noted in Fig. 3, indicating that all of the rival trees resolved the Alexandrium sequences in a similar fashion (data not shown). Thirdly, the tree building program was also run using "simple," "random" and "as is" addition sequences (Swofford 1990), and all resulted in trees identical to that shown in Fig. 3. Finally, boostrap analysis was performed as a statistical test of branching patterns (Felsenstein 1985). Results of this test (Fig. 4) also support the existence of at least eight Alexandrium ribotypes as proposed in Fig. 3. 
Figure 3. Phylogenetic tree inferred from the aligned Alexandrium LsrDNA sequences (generated by PAUP 3.0, Swofford 1991; based on 405 apomorphic characters; see also Materials and Methods). Alexandrium minutum, $\underline{\text { A. }}$ lusitanicum and $\underline{\mathrm{A}}$. $\underline{\text { andersoni were }}$ defined as the outgroup since they all share a common SsrDNA restriction pattern (Scholin and Anderson, submitted manuscript) and are the most divergent relative to those isolates within the A. tamarense/catenella/fundyense species complex. Branch lengths reflect the relatedness of the sequences (e.g., G. Hope 1 and G. Crux differ by one nucleotide). "North American," "Western European," "Temperate Asian," "Tasmanian," "Tropical Asian," "affine," "minutum" and "andersoni" are proposed ribotype designations given to terminal taxa. Toxic isolates are donoted by "*." Ensemble statistical indices are as follows: consistency index $(\mathrm{CI})$ excluding uninformative characters $=0.806$; homoplasy index $(\mathrm{HI})$ excluding uninformative characters $=0.194$; retention index $(\mathrm{RI})=0.948$; rescaled consistency index $(\mathrm{RC})=0.794$ (cf. Swofford 1991). SsrDNA RFLP characteristics for the cultures are also shown on the appropriate branches; note the correspondence between SsrDNA RFLP patterns and LsrDNA phylogeny (Table 2; cf. Chapt. 2). 


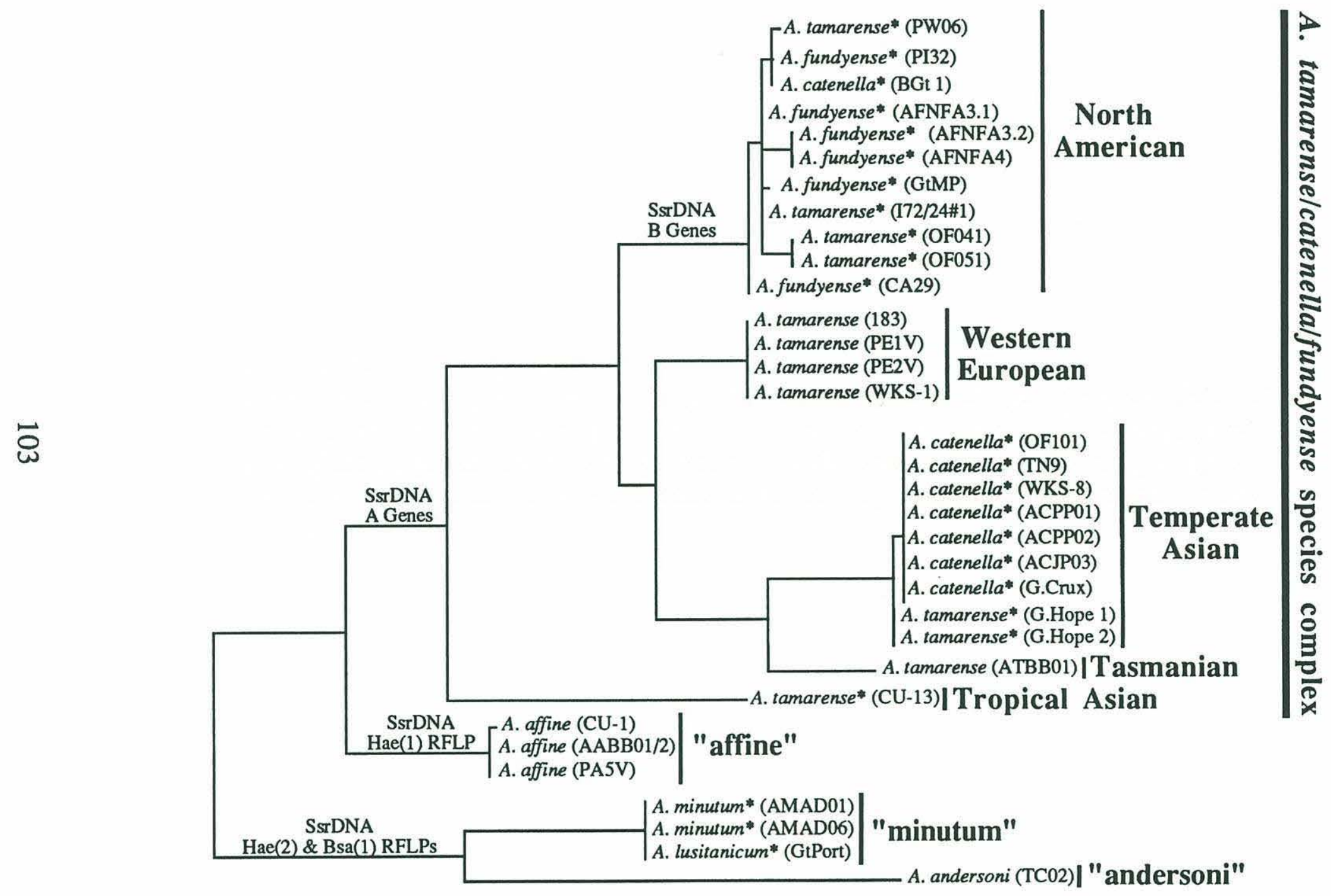


Figure 4. Parsimony booststrap consensus tree inferred from 500 resamplings of the aligned Alexandrium LsrDNA sequences (generated by PAUP 3.0, Swofford 1991; see also Materials and Methods). Numbers indicate the frequency (\%) that taxa to the right of the value were found to group together. Proposed ribotypes as listed in Fig. 3 are also shown. 


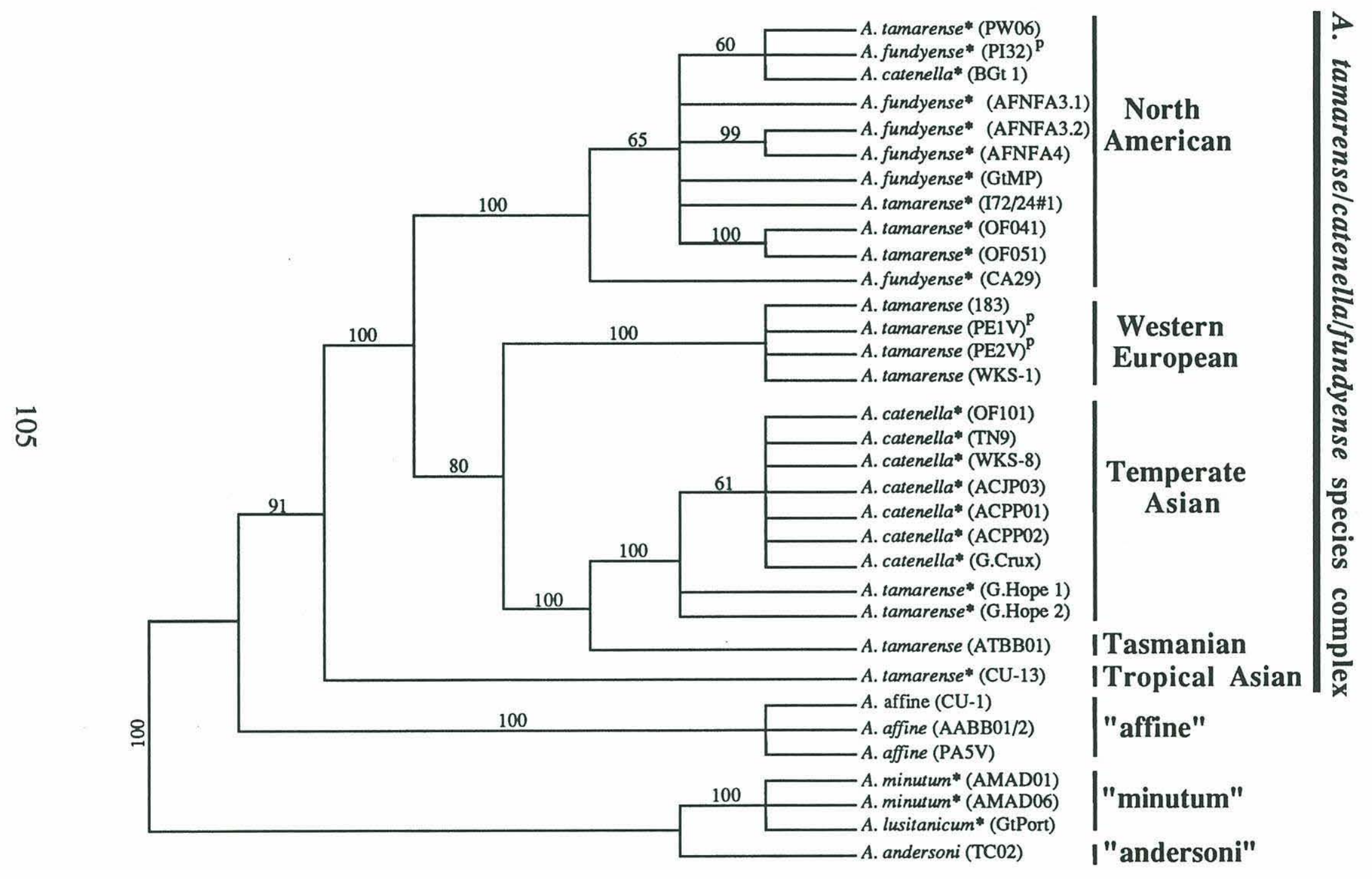


Definition of Alexandrium Ribotypes

Five of the ribotypes serve to subdivide members of the Alexandrium tamarense/catenella/fundyense species complex. The three remaining ribotypes were associated with cultures that clearly differ morphologically from the $\underline{A}$. tamarense/catenella/fundyense group; these three distinct sequences are typified by: 1) $\underline{A}$. affine; 2)

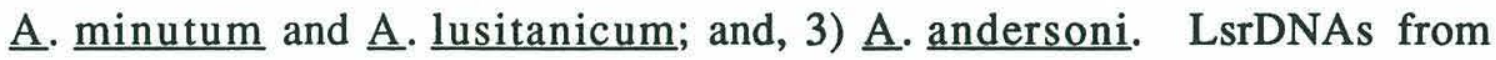

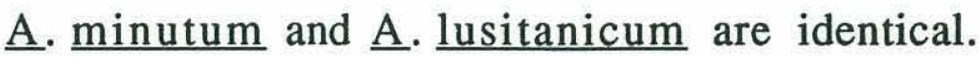

The five distinct Alexandrium tamarense/catenella/fundyense ribotypes were named with reference to the geographic origin of the isolates: "North American," "Western European" and "Temperate Asian" designations reflect the origins of the majority of cultures within each cluster; "Tasmanian" and "Tropical Asian" designations reflect the origins of single $\underline{A}$. tamarense cultures. Alexandrium species designations were used to identify the three remaining ribotypes: "affine" and "minutum" were chosen for two of these; "andersoni" was chosen to delineate the final ribotype, reflecting both its unique LsrDNA sequence and the isolate's taxonomic classification (see Table 2). 
Table 2. Comparison of SsrDNA RFLP groups and LsrDNA ribotypes of Alexandrium isolates. Toxicity data, species designations and isolation locales of the examined strains are also presented.

\section{SsrDNA} Restriction Group $^{\text {a }}$

\begin{tabular}{|c|c|c|c|c|c|c|}
\hline & North & eastern ${ }^{c}$ & $\begin{array}{l}\text { GtCA29 } \\
\text { AFNFA3 } \\
\text { AFNFA4 } \\
\text { GtMP } \\
\text { I72/24\#1 }\end{array}$ & $\begin{array}{l}\text { yes } \\
\text { yes } \\
\text { yes } \\
\text { yes } \\
\text { yes }\end{array}$ & $\begin{array}{l}\text { A. fundyense } \\
\text { A. fundyesne } \\
\text { A. tamarense } \\
\text { A. fundyense } \\
\text { A. tamarense }\end{array}$ & $\begin{array}{l}\text { Cape Ann, MA } \\
\text { Newfoundland } \\
\text { Newfoundland } \\
\text { Orleans, MA } \\
\text { ballast water (Muroran, Japan) f }\end{array}$ \\
\hline & American & western $^{\mathrm{c}}$ & $\begin{array}{l}\text { PW06 } \\
\text { PI32 } \\
\text { BGt } 1\end{array}$ & $\begin{array}{l}\text { yes } \\
\text { yes } \\
\text { yes }\end{array}$ & $\begin{array}{l}\text { A.tamarense } \\
\text { A. tamarense } \\
\text { A. catenella }\end{array}$ & $\begin{array}{l}\text { Port Benny, Alaska } \\
\text { Porpoise Isl., Alaska } \\
\text { Russian River, CA }\end{array}$ \\
\hline & & alternate ${ }^{\mathrm{c}} \mid$ & $\begin{array}{l}\text { OF041 } \\
\text { OF051 }\end{array}$ & $\begin{array}{l}\text { yes } \\
\text { yes }\end{array}$ & $\begin{array}{l}\text { A. tamarense } \\
\text { A. tamarense }\end{array}$ & $\begin{array}{l}\text { Ofunato Bay, Japan } \\
\text { Ofunato Bay, Japan }\end{array}$ \\
\hline & Western Eu & ropean & $\begin{array}{l}\text { Pgt } 183 \\
\text { PE1V } \\
\text { PE2V } \\
\text { WKS-1 }\end{array}$ & $\begin{array}{l}\text { no } \\
\text { no } \Psi \\
\text { no } \\
\text { no }\end{array}$ & $\begin{array}{l}\text { A. tamarense } \\
\text { A. tamarense } \mathrm{e} \\
\text { A. tamarense } \\
\text { A. tamarense }\end{array}$ & $\begin{array}{l}\text { Plymouth, U.K. } \\
\text { Galicia, Spain } \\
\text { Galicia, Spain } \\
\text { Tanabe Bay, Japan }\end{array}$ \\
\hline III & $\begin{array}{l}\text { Temperate } \\
\text { Asian }\end{array}$ & Japanese $^{\mathrm{c}}$ & $\begin{array}{l}\text { OF101 } \\
\text { TN9 } \\
\text { WKS-8 } \\
\text { ACJP03 } \\
\text { ACPP01 } \\
\text { ACPP02 } \\
\text { G. Crux }\end{array}$ & $\begin{array}{l}\text { yes } \\
\text { yes } \\
\text { yes } \\
\text { yes } \\
\text { yes } \\
\text { yes } \\
\text { yes }\end{array}$ & $\begin{array}{l}\text { A. catenella } \\
\text { A. catenella } \\
\text { A. catenella } \\
\text { A. catenella } \\
\text { A. catenella } \\
\text { A. catenella } \\
\text { A. catenella }\end{array}$ & $\begin{array}{l}\text { Ofunato Bay, Japan } \\
\text { Tanabe Bay, Japan } \\
\text { Tanabe Bay, Japan } \\
\text { ballast water (Kashima, Japan) f } \\
\text { Port Phillip Bay, Australia } \\
\text { Port Phillip Bay, Australia } \\
\text { ballast water (Singapore?) g }\end{array}$ \\
\hline & & Korean ${ }^{\mathrm{c}} \mid$ & $\begin{array}{l}\text { G. Hope } 1 \\
\text { G. Hope } 2\end{array}$ & $\begin{array}{l}\text { yes } \\
\text { yes }\end{array}$ & $\begin{array}{l}\text { A. tamarense } \\
\text { A. tamarense }\end{array}$ & $\begin{array}{l}\text { ballast water (Samchonpo, S. Korea) f } \\
\text { ballast water (Samchonpo, S. Korea ) }\end{array}$ \\
\hline & Tas & manian | & ATBB01 & no $\Psi$ & A. tamarense & Bell Bay, Tasmania \\
\hline & Tropical & Asian & CU13 & yes & A. tamarense & Gulf of Thailand \\
\hline IV & & affine" & $\begin{array}{l}\mathrm{AABB} 01 / 2 \\
\text { PA5V } \\
\text { CU1 }\end{array}$ & $\begin{array}{l}\text { no } \\
\text { no } \\
\text { no }\end{array}$ & $\begin{array}{l}\text { A. affine } \\
\text { A. affine } \\
\text { A. affine }\end{array}$ & $\begin{array}{l}\text { Bell Bay, Tasmania } \\
\text { Galicia, Spain } \\
\text { Gulf of Thailand }\end{array}$ \\
\hline V & \multicolumn{2}{|c|}{ "minutum" } & $\begin{array}{l}\text { AMAD01 } \\
\text { AMAD06 } \\
\text { GTPORT }\end{array}$ & $\begin{array}{l}\text { yes } \\
\text { yes } \\
\text { yes }\end{array}$ & $\begin{array}{l}\text { A. minutum } \\
\text { A. minutum } \\
\text { A. lusitanicum }\end{array}$ & $\begin{array}{l}\text { Port River, S. Australia } \\
\text { Port River, S. Australia } \\
\text { Portugal }\end{array}$ \\
\hline & \multicolumn{2}{|c|}{ "andersoni" | } & $\mathrm{TC} 02$ & no & A. andersoni & Eastham, MA \\
\hline
\end{tabular}

a) RFLP groups are based on results of the SsrDNA A/B gene restriction tests (Chapt. 2)

b) subdivisions based on results of LsrDNA sequence analysis (see Figs. 3 and 4)

c) preliminary "subribotype" designations based on fine-scale sequence variations (Appendix C)

d) determined by mouse bioassay and/or HPLC analysis; " $\Psi$ " may contain trace amounts of toxin (D. Kulis, pers. comm.)

e) preliminary species designations

f) presumed origins (Hallegraeff and Bolch, 1992)

g) hailing port of vessel - origin of ballast water uncertain (Hallegraeff and Bolch, 1992) 


\section{DISCUSSION}

Sequence analysis of the LsrDNA fragments from geographically-diverse representatives of the Alexandrium tamarense/catenella/fundyense species complex revealed the existence of at least five genetically-distinct strains (Figs. 3 and 4, Table 2). These strains ("ribotypes") do not strictly correspond to morphospecies designations, indicating that the morphological features of $\underline{A} . \underline{\text { tamarense, }} \underline{A}$. $\underline{\text { catenella }}$ and $\underline{A}$. fundyense are less specific indicators of the organisms' relationships than are their LsrDNA sequences. Particular regional populations of $\underline{A}$. tamarense, $\underline{A}$. $\underline{\text { catenella }}$ and $\underline{\mathrm{A}}$. $\underline{\text { undyense }}$ appear to have distinct sequence characteristics, but some of these regions are under-sampled and currently represented by only a few or single isolates. Given the isolates examined thus far, $\underline{\text { A.tamarense, }} \underline{\mathrm{A}}$. catenella or $\underline{\text { A. }}$. fundyense collected from the same geographic region appear the most similar regardless of morphospecies designations, whereas those from geographically-isolated populations are more divergent even when the same morphospecies are compared. Alexandrium $\underline{\text { tamarense }}$ and $\underline{\mathrm{A}}$. catenella from Japan are a notable exception to this general trend, possibly because some $\underline{A}$. $\underline{\text { tamarense }}$ are the descendants of introduced species (see below). LsrDNA sequences from $\underline{A}$. affine, $\underline{A}$. minutum, $\underline{A}$. lusitanicum and $\underline{A}$. andersoni show that these organisms are distinct from the $\underline{\text { A. tamarense/catenella/ }}$ fundyense complex. Furthermore, $\underline{A}$. affine is clearly separable from the $\underline{A}$. minutum/lusitanicum/andersoni group. Likewise, $\underline{A}$. andersoni differs from $\underline{A}$. minutum/lusitanicum, but $\underline{\mathrm{A}}$. minutum 
and $\underline{\mathrm{A}}$. lusitanicum are indistinguishable (Figs. 3 and 4, Table 2). $\underline{\text { Alexandrium minutum, }} \underline{\text { A. }} \underline{\text { lusitanicum }}$ and $\underline{\mathrm{A}}$. $\underline{\text { andersoni may be }}$ members of yet another Alexandrium species complex. These results both corroborate and extend previous observations based on RFLP analyses of SsrDNAs (Chapt. 2). Thus, Ss and LsrDNA sequences are useful species- and strain-specific (or population-specific) genetic markers. As such, these sequences provide new insights to on-going taxonomic debates. Moreover, the definition of genetically-distinct populations of Alexandrium provides a reference from which dispersal hypotheses can be tested. These and other issues are discussed in detail below.

Comparisons of Alexandrium SsrDNA RFLP Patterns and LsrDNA Sequences

Relationships among the Alexandrium cultures used in this investigation have also been assessed by an RFLP analysis of their SsrDNAs (Chapt. 2). The restriction tests were specifically designed to rapidly screen cultures for the presence of two distinct SsrDNAs, the "A gene" and "B gene," found in a North American $\underline{\mathrm{A}}$. fundyense (GtCA29; Chapt. 1). The enzymes used in that study detect only a few differences between the A and B sequences, but nonetheless appeared to be useful in typing a variety of Alexandrium species. SsrDNA RFLP patterns revealed three subdivisions ("Groups I-III") within the $\underline{\mathrm{A}}$. tamarense/catenella/fundyense species complex. These groups encompass at least five LsrDNA ribotypes reported here: North American, Western European, Temperate Asian, 
Tasmanian and Tropical Asian (Table 2). ${ }^{2}$ Alexandrium minutum, $\underline{\mathrm{A}}$.

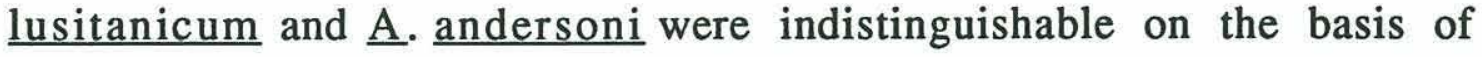
SsrDNA restriction analysis ("Group V"), but Ls sequences clearly indicate that $\underline{\mathrm{A}}$. andersoni is distinct from the $\underline{\mathrm{A}}$. minutum/ lusitanicum cluster. Thus, ribotypes ascribed by the LsrDNA sequences are in complete agreement with, and offer a finer-scale resolution of, groups defined by the SsrDNA RFLP analyses.

\section{Alexandrium LsrDNA Ribotypes and Their Relation to Toxicity}

Toxic Alexandrium cluster at several different termini on the phylogenetic tree (Fig. 3). The North American, Temperate Asian and "minutum" groups thus far consist exclusively of toxic isolates. In contrast, the Western European group encompasses only non-toxic organisms. Terminal taxa classified as Australian, Tropical Asian and "andersoni" are also non-toxic. Preliminarily, this suggests that an organism's ability to produce toxin is correlated with its LsrDNA phylogenetic lineage; that is, its evolutionary history (Fig. 3 and Table 2). As the data base of sequences from toxic and nontoxic Alexandrium species grows, it will be possible to rigorously address this potential correlation. While certain ribotypes may be represented exclusively by toxic or non-toxic Alexandrium strains, there is no clear lineage of toxicity on the phylogenetic tree (Fig. 3). The clusters of non-toxic isolates among those that are exclusively

2 "subribotypes" within the North American and Temperate Asian clusters have also been proposed on the basis of fine-scale, reproducible LsrDNA characteristics, but should be considered preliminary designations (Appendix C) 
toxic may in fact reflect "evolutionary mutants" that have "lost" their ability to produce toxin.

The Alexandrium tamarense/catenella/fundyense Complex

There is no strict correlation between Alexandrium tamarense, $\underline{\mathrm{A}} . \underline{\text { catenella }}$ and $\underline{\mathrm{A}}$. $\underline{\text { fundyense }}$ morphospecies designations and the ribotypes of their globally-distributed representatives. The various morphospecies can appear genetically-similar or genetically-distinct, depending upon the particular strains (populations) compared (Figs. 3 and 4; Table 2). ${ }^{3}$ For example, I72/24\#1 (‥ tamarense; Japan) is genetically-distinct from ACPP01 (‥ catenella; Australia). However, the former isolate (․․ tamarense; Japan) is also genetically-divergent from G. Hope 1 (‥ tamarense; South Korea). Furthermore, the latter isolate (A. tamarense; South Korea) is genetically-similar to ACPP01 (A. catenella; Australia; Table 2). The isolates cited in these examples were classified using the same morphospecies criteria (Hallegraeff et al. 1991, Hallegraeff and Bolch 1992, Hallegraeff, pers. comm.); therefore, the agreements or disagreements between ribotype and morphotype are not solely attributable to different taxonomists applying different morphospecies criteria. This same conclusion was reached when comparing SsrDNA RFLP patterns and morphospecies designations (Chapt. 2).

3 "morphotype" refers to the ensemble of genes responsible for cells' morphology, whereas "genotype" refers to specific sub-cellular characteristics, such as rDNA sequence 
The confusing associations between morphotype and "genotype" may be understood in the context of the evolution of the Alexandrium tamarense/catenella/fundyense species complex. Present-day morphological variation is not attributable to independently-evolved, distinct ancestral lines (Chapt. 4; Cembella et al. 1988). Instead, it is proposed that the three morphospecies arose from a single ancestral stock that dispersed to various regions of the world over millions of years. The dispersing populations are presumed to have become geographically-isolated and to have diverged genetically, albeit maintained an overall conserved morphology (Chapt. 4). This hypothesis predicts that a molecular phylogeny of globally-distributed $\underline{A}$. tamarense/catenella/fundyense should ascribe as a series of genetically-distinct strains, each one of which may be encompass one or more morphospecies. The strains' phylogenetic lineages should reflect the evolution of geographicallyisolated populations, not morphospecies (Chapt. 4).

Among the isolates examined thus far, these predictions are largely met: geographically co-occurring Alexandrium tamarense, $\underline{\text { A. }}$. $\underline{\text { catenella }}$ or $\underline{A}$. fundyense appear to be closely-related, while geographically-separated populations of any one of these species are divergent. For example, isolates from Australia, North America or Western Europe are distinguishable from one another, but within each of these regions there is a high degree of similarity, or even identity. However, two exceptions to this general pattern are noteworthy. First, $\underline{A} . \underline{\text { tamarense }}$ and $\underline{A}$. catenella collected from Japan are represented by Temperate Asian, North American or 
Western European ribotypes. This diversity is also evident in ballast water cultures thought to originate in Japan (Table 2). This pattern is consistent with the recent introduction of these species from a variety of genetically-distinct source populations. It is believed the introduced organisms include, but are not limited to, $\underline{\mathrm{A}}$. $\underline{\text { tamarense }}$ from North America (Scholin and Anderson 1992, Chapt. 2). A more thorough discussion of this possibility is presented elsewhere (Chapt. 4). Second, the toxic $\underline{A}$. catenella from Australia are essentially identical to the Temperate Asian strains found in Japan. Recent work by Hallegraeff and co-workers (Hallegraeff et al 1991, Hallegraeff and Bolch 1992) suggests $\underline{A}$. catenella could have been introduced to Australia via ships' ballast water. The ribosomal sequence analysis reported here also indicate that these organisms potentially originated in Japan. Some regions of the world, however, are undersampled or have not yet been sampled; consequently, other source populations cannot be discounted (see Chapt. 4).

The $\underline{\text { Alexandrium }} \underline{\text { affine }}$ and $\underline{A} . \underline{\text { minutum/lusitanicum/andersoni }}$ Complexes

Representatives of $\underline{\text { Alexandrium }}$ affine, $\underline{A}$. minutum, $\underline{\mathrm{A}}$.

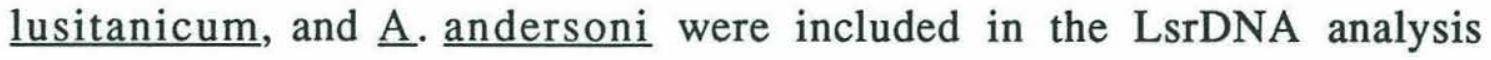
in order to assess the fidelity of the Ls fragment to discriminate what are considered to be distinct morphospecies from those within the $\underline{\mathrm{A}}$. tamarense/catenella/fundyense group. In accordance with current morphotaxonomic designations, $\underline{A} . \underline{\text { affine }}, \underline{\mathrm{A}} \cdot \underline{\text { minutum, }} \underline{\mathrm{A}} . \underline{\text { lusitanicum }}$ 
and $\underline{\mathrm{A}}$. andersoni are clearly distinct from members of the $\underline{\mathrm{A}}$. tamarense/catenella/fundyense complex.

The distinction between Alexandrium affine and the $\underline{\mathrm{A}}$. minutum/1usitanicum/andersoni group, and further differentiation between $\underline{A}$. andersoni and the $\underline{A}$. minutum/lusitanicum cluster also agrees with established taxonomic criteria. However, the Ls sequences fail to differentiate between $\underline{A}$. minutum and $\underline{A}$. lusitanicum. Hallegraeff (pers. comm.) has suggested that $\underline{\mathrm{A}}$. $\underline{\text { minutum, }} \underline{\mathrm{A}} . \underline{\text { lusitanicum }}$ and $\underline{\mathrm{A}}$. andersoni are closely-related, and that the morphological differences used to delineate these organisms may not warrant unique species classifications. In part his view is supported by the LsrDNA sequence data and toxicity determinations: $\underline{\text { A. }}$ minutum and $\underline{\mathrm{A}}$. $\underline{\text { lusitanicum }}$ do share the same ribotype and are both toxic. However, $\underline{A}$. andersoni's sequence is clearly different, and A. andersoni is non-toxic. Thus, both rDNA sequences and toxicity data support a distinction between the $\underline{A}$. minutum/lusitanicum group and $\underline{\mathrm{A}}$. andersoni, but do not support a distinction between $\underline{\mathrm{A}}$. minutum and $\underline{\mathrm{A}}$. lusitanicum. Variance between $\underline{\mathrm{A}}$. minutum/ lusitanicum and $\underline{\mathrm{A}}$. $\underline{\text { andersoni }}$ is approximately the same as that between the North American and Tropical Asian ribotypes of the $\underline{A}$. tamarense/catenella/fundyense complex (Fig. 3). Alexandrium minutum, $\underline{\mathrm{A}}$. $\underline{\text { lusitanicum }}$ and $\underline{\mathrm{A}}$. andersoni may be members of yet another Alexandrium species complex, analogous to the $\underline{\mathrm{A}}$. tamarense/catenella/fundyense group. Sequence analysis of additional $\underline{\mathrm{A}}$. minutum, $\underline{\mathrm{A}}$. $\underline{\text { lusitanicum }}$ and $\underline{\mathrm{A}}$. $\underline{\text { andersoni }}$ isolates from diverse source populations will be needed to address this possibility. 
Morphological, Enzyme Electrophoretic and Toxin Composition Analyses: Re-evaluation of Conflicting Conclusions

Taxonomic authorities agree that Alexandrium tamarense, $\underline{\text { A. }}$. catenella and $\underline{\mathrm{A}}$. $\underline{\text { fundyense }}$ are closely-related. Their distinction as "species" is based on fine-scale features amidst a background of similar morphology (Balech 1985, Balech and Tangen 1985, Fukuyo 1985). Some authorities believe that these morphological differences warrant the use of unique species assignments, while others argue that the morphological variants represent strains, or "varieties," of a single species (Balech 1985, Fukuyo 1985, Taylor 1985, Cembella and Taylor 1986, Cembella et al. 1987, 1988, Hayhome et al. 1989). A number of laboratories have attempted to resolve this debate using biochemical markers to independently assess the genetic relatedness of isolates representing the different morphotypes. However, results of such comparisons have not been consistent. For example, isolates of $\underline{A}$. tamarense and $\underline{A}$. catenella from Japan have been distinguished on the basis of their morphology, isozyme electrophoretic patterns, toxin composition and cell surface antigens (Fukuyo 1985, Sako et al. 1990, Sako 1992, Sako et al 1992). Thus, there is strong support for the morphospecies concept. In contrast, there is no strict correlation between morphotype and enzyme electrophoretic patterns or toxin compositions of eastern North American $\underline{\mathrm{A}}$. tamarense and $\underline{\mathrm{A}}$. fundyense (Hayhome et al. 1989, Anderson, unpublished data), and western North American $\underline{\mathrm{A}}$. tamarense and $\underline{\mathrm{A}}$. catenella (Cembella and Taylor 1986, Cembella et al. 1987, 1988). Thus, the genetic 
characteristics of these isolates provide no support for the morphospecies concept.

Results of the present study offer an explanation as to how these parallel investigations have yielded both positive and negative correlations between morphospecies designations and biochemical (genetic) characteristics. Overall, the resolution afforded by the LsrDNA phylogeny is one of geography, not morphology. As outlined above and described in detail elsewhere (Chapt. 4), this result is consistent with the hypothesis that the Alexandrium tamarense/ catenella/fundyense complex arose from a single ancestral stock that over the course of its evolution became fragmented into geographically-isolated populations. Thus, isolates from an indigenous population should appear genetically-similar, even if more than one morphospecies is present, whereas representatives from geographically-separate populations should appear geneticallydistinct, regardless of morphotype. However, recent dispersal events will confound the association between "genotype" and "geographically-isolated population." For example, if a particular strain of $\underline{\mathrm{A}}$. tamarense/catenella/fundyense is introduced to a region free of these species, then the resulting "new" assemblage will be morphologically- and genetically-similar to the population from which it dispersed. Alternatively, if a strain of $\underline{\text { A. tamarense/ }}$ catenella/fundyense is introduced to a region with a pre-existing population of these species, or if multiple strains are introduced, then the resulting assemblage should display a mixture of morphologic and genetic signatures indicative of each, previously-isolated strain. 
The latter scenario could explain the co-occurrence of genetically-divergent Alexandrium tamarense and $\underline{\mathrm{A}}$. catenella in Japan; contemporary populations of these organisms may in fact be a mixture of distinct, evolutionary lineages that until recently were geographically-isolated and evolving independently (Chapt. 4). It is noteworthy that representative $\underline{\mathrm{A}} \underline{\text { tamarense }}$ and $\underline{\mathrm{A}}$. catenella from Japan harbor North American and Temperate Asian ribotypes, respectively. Given these organisms' phylogenetic affinities (Fig. 3) and morphotypes, is not surprising that their biochemical and genetic characteristics are positively correlated with morphospecies designations. Thus, "support" for the morphospecies concept in this case may simply be fortuitous, reflecting the particular assemblage

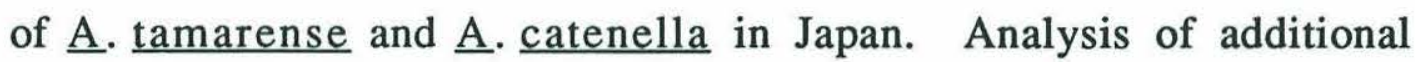
isolates will help substantiate this claim.

In contrast to Japan, eastern North American populations of Alexandrium tamarense and $\underline{\mathrm{A}}$. $\underline{\text { fundyense }}$ appear to be relatively homogeneous with respect to their protein electrophoretic patterns (Hayhome et al., 1989) and SsrDNA and LsrDNA characteristics, despite the fact that they are classified as distinct morphospecies. This homogeneity is consistent with the proposed evolutionary scheme for the A. tamarense/catenella/fundyense complex: both $\underline{\mathrm{A}}$. fundyense and $\underline{A}$. tamarense appear genetically-similar and are from the same region. Furthermore, it supports the contention that eastern North American A. tamarense/fundyense have recently dispersed from a common source population in eastern Canada to 
points southward that were largely free of these organisms (Anderson 1989, Hayhome et al. 1989).

Cembella et al. (1988) concluded that Alexandrium tamarense and $\underline{A}$. catenella isolated from western North America (British Columbia and Washington) and several other regions represented members of a species complex whose genetic diversity "is not paralleled by corresponding morphological divergence." That conclusion is fully supported by results presented here. Similar to Hayhome et al. (1989), Cembella et al. (1988) found no genetic basis to distinguish western North American $\underline{A}$. $\underline{\text { tamarense }}$ and $\underline{\mathrm{A}}$. $\underline{\text { catenella }}$ morphospecies; however, unlike the relatively homogeneous assemblage of $\underline{A}$. tamarense/fundyense found in eastern North

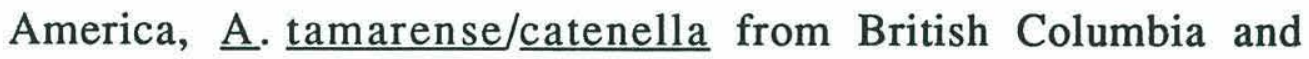
Washington are considered to be genetically-diverse (Boczar et al. 1991, Cembella et al. 1988). Only three western North American A. $\underline{\text { tamarense }}$ and $\underline{\mathrm{A}}$. catenella were included in this study, and none of these originate from British Columbia or Washington The western North American isolates that were examined (Alaska and California) harbor nearly identical LsrDNA sequences, suggesting a genetic similarity (see below). Possible explanations for the genetic divergence among $\underline{A}$. tamarense/catenella noted by Boczar et al. (1991) and Cembella et al. (1988) are considered elsewhere (Chapt. 6).

For those isolates that have been analyzed by both protein electrophoretic and rDNA sequencing, the results agree remarkably 
well: isozyme banding patterns of eastern North American $\underline{\mathrm{A}}$.

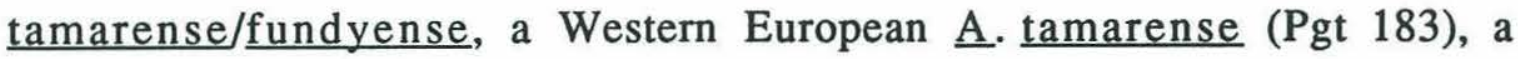
Spanish $\underline{\text { A. }}$ affine $(\mathrm{PA} 5 \mathrm{~V})$ ) and an eastern North American $\underline{\mathrm{A}}$. andersoni (TC02) showed the toxic, eastern North American A. tamarense/fundyense group to be a single, closely-related cluster; relative to that group, Pgt183, PA5V and TC02 are progressively more divergent (Hayhome et al. 1989). Ribosomal RNA gene sequences for these same organisms reveal an identical tree topology [Figs. 3 and Table 2 (North American> Western European> "affine"> "andersoni")]. In a separate study, Sako et al. (1990) have shown that OF041(‥ tamarense) and OF101 (‥ catenella), both from Japan, are distinguishable on the basis of their isozyme electrophoretic patterns; they are also members of the North American and Temperate Asian groups, respectively (Fig. 3 and Table 2). Thus, LsrDNA ribotypes and protein electrophoretic patterns appear to ascribe the same groups. This observation coupled with the fact that LsrDNA sequences from globally-distributed representatives of $\underline{\mathrm{A}}$.

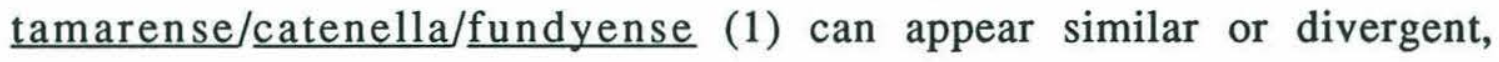
irrespective of an isolates' morphotype, and (2) and are nonuniformly distributed throughout the world, indicates that different regional populations can have unique combinations of morphotypes and genotypes. The seemingly disparate observations reported by Sako et al. (1990), Hayhome et al. (1989) and Cembella and coworkers (Cembella and Taylor 1986, Cembella et al. 1987, 1988) appear to reflect this: the majority of cultures characterized in each investigation were indeed collected from different regional populations. Therefore, the agreement or disagreement between 
morphology and other subcellular characteristics may simply depend on the particular isolates chosen for analysis. This is precisely the result expected if populations of $\underline{A}$. tamarense, $\underline{A}$. catenella and $\underline{A}$. fundyense arose monophyletically (Chapt. 4).

The relationship between LsrDNA ribotypes and toxin composition profiles are largely unknown. Preliminarily, toxin profiles can be more variable than LsrDNA sequences (Anderson, unpublished data). The correlation, or lack thereof, between LsrDNA ribotype and sexual compatibility of isolates is also unclear. At the time of this writing, isolates from the North American and Western European groups appear compatible. Similarly, a representative of the North American ribotype appears compatible with the Tasmanian isolate (Anderson, unpublished data). Thus, at least some representatives of the different ribotypes appear capable of interbreeding, but this is based on a limited number of crosses.

$\underline{\text { Alexandrium tamarense/catenella/fundyense }}$ and the Species Concept

Despite the fact that we can discern relationships among members of the Alexandrium tamarense/catenella/fundyense complex, there is no internationally-accepted standard against which these relationships can be measured and "species" defined. Morphological features are essential in Alexandrium species descriptions, but can be misleading if used as the sole reference for describing a populations' biogeography or potential dispersal. 
Isozyme electrophoretic patterns, toxin compositions, antibody crossreactivities and sequences of ribosomal RNA genes all provide characterization at the subcellular level, but the designation of "species" based strictly on one or more of these criteria is problematic: what is a "biochemical species," and how could one define species boundaries using such criteria? A stricter, biological definition of "species" would be one based on sexual compatibility (Sako et al. 1990). This, too, would be a problematic criterion given the difficulties inherent in mating experiments, and interpretation of crosses that may yield a low frequency of viable progeny (Destombe and Cembella 1990).

The problem in defining "species" for members of the Alexandrium tamarense/catenella/fundyense complex is largely idiosyncratic: morphology does belie an underlying genetic diversity, yet morphology is the most universally-accepted and accessible means of describing the organisms. A solution to this dilemma is to use standardized morphotype descriptions, but also include "strain designations" that convey an indication of a particular organism's genetic characteristics when such information is relevant; this same scheme is routinely applied in bacterial taxonomy [(e.g., E. coli JM109 (Ausubel et al. 1987)]. The sequences of ribosomal genes and their gene products could be useful in this regard. For example, in a cross

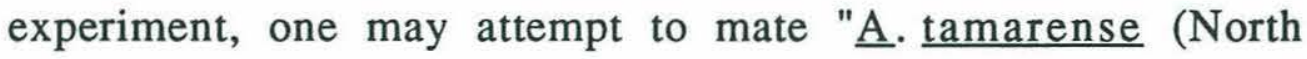
American)" and "ㅁ.tamarense (Temperate Asian)." In another example, a series of genus-, species- and strain-specific rRNAtargeted oligonucleotide probes could be used as aids to help 
determine the "species" and "strain" of an isolate, or "species" and "strain composition" of preserved field samples, but the actual designations would still be rooted in morphological descriptions. A series of monoclonal antibodies directed at cell surface antigens have the same potential (Sako, 1992). Toxin composition analyses by HPLC could also be useful in such "strain" determinations, but at present appear to be more technically-demanding and labor intensive than applying either nucleic acid or immunological probes. In addition, strain designations based on toxin profiles offer no resolution for non-toxic organisms, such as some $\underline{A}$. $\underline{\text { tamarense. }}$

\section{Concluding Remarks}

The recognition of genetically-distinct Alexandrium species and populations offers a new genetic reference from which debates concerning the relationships between $\underline{A}$. tamarense/catenella/ fundyense morphological and biochemical characters may be viewed. Results of the present study could foster a resolution to this long standing controversy, and thus a unified systematic scheme may now be in reach. The definition of genetic markers for certain regional populations also sets the stage for their use in testing dispersal hypotheses. An encouraging aspect of Ss and LsrDNA analysis is the identification of Alexandrium genus-, species- and strain-specific sequences. Oligonucleotide probes designed to recognize each of these markers are now being tested. It is conceivable that this series of probes could be used to rapidly classify, enumerate and separate whole cells collected in culture or field samples (Amann et al. 1990). 
Organisms' reactivity towards certain probes may also be useful for making predictions about their isozyme characteristics, toxin production capabilities, antibody cross-reactivity or population mating type affinities if strong associations between particular ribosomal signatures and biochemical characteristics actually exist.

\section{Literature cited}

Amann, R.I., Binder, B.J., Olson, R.J., Chisholm, S.W., Devereux, R., Stahl, D.A. (1990). Combination of 16S rRNA-targeted oligonucleotide probes with flow cytometry for analyzing mixed microbial populations. Appl.Environ.Microbiol. 56:1919-1925.

Anderson, D.M. (1989). Toxic algal blooms and red tides: a global perspective. In : Okaichi,T., Anderson, D.M., and Nemoto,T. (eds.) Red tides: biology, environmental science and toxicology. Elsevier, New York, pp. 11 - 20.

Anderson, D.M., Kulis, D.M., Binder, B.J. (1984). Sexuality and cyst formation in the dinoflagellate Gonyaulax tamarensis: cyst yield in batch cultures. J.Phycol. 20: 418-425.

Ausubel, F.M., Brent, R., Kingston, R.E., Moore, D.D., Siedman, J.G., Smith, J.A., Struhl, K. (eds.) (1987). Current Protocols in Molecular Biology. Wiley Interscience, New York. Vols. 1 and 2.

Balech, E. (1985). The genus Alexandrium or Gonyaulax of the tamarensis group. In : Anderson, D.M., White, A.W., Baden, D.G. (eds.) Toxic Dinoflagellates. Elsevier, New York, pp. 33 - 38.

Balech, E., Tangen, K. (1985). Morphology and taxonomy of toxic species in the tarmarensis group (Dinophyceae): Alexandrium excavatum (Braarud) comb. nov. and Alexandrium ostenfeldii (Paulsen) comb. nov. Sarsia 70: 333-343. 
Boczar, B. A., Liston, J., Cattolico, R. A. (1991). Characterization of satellite DNA from three marine dinoflagellates (Dinophyceae): Glenodinium sp. and two members of the toxic genus Protogonyaulax. Plant Physiol. 89: 613-618.

Cembella, A.D., Taylor, F.J.R., Therriault, J.-C. (1988). Cladistic analysis of electrophoretic variants within the toxic dinoflagellate genus Protogonyaulax. Botanica Marina 31: 3951 .

Cembella, A.D., Sullivan, J.J., Boyer, G.L., Taylor, F.J.R., Andersen, R.J. (1987). Variation in paralytic shellfish toxin composition within the Protogonyaulax tamarensis/catenella species complex: red tide dinoflagellates. Biochem.Syst.and Ecol. 15: $171-186$.

Cembella, A.D., Taylor, F.J.R. (1986). Electrophoretic variability within the Protogonyaulax tamarensis/catenella species complex: pyridine linked dehydrogenases. Biochem.Syst.and Ecol. 14: 311-323.

Destombe, C., Cembella, A.D., Murphy, C.A., Ragan, M.A. (1992). Nucleotide sequence of the $18 \mathrm{~S}$ ribosomal RNA genes form the marine dinoflagellate Alexandrium tamarense (Gonyaulacales, Dinophyta). Phycologia 31: 121-124.

Destombe, C., Cembella, A.D. (1990). Mating type determinations, gametic recognition and reproductive success in Alexandrium excavatum (Gonyaulacales, Dinophyta), a toxic red-tide dinoflagellate. Phycologia 29: 316-325.

Felsenstein, J. (1985). Confidence limits on phylogenies: an approach using the bootstrap. Evolution 38:16-24.

Fukuyo, Y. (1985). Morphology of Protogonyaulax tamarensis (Lebour) Taylor and Protogonyaulax catenella (Whedon and Kofoid) Taylor from Japanese coatal waters. Bull. Marine Sci. 37: 529-537.

Hallegraeff, G., Bolch, C.J. (1991). Transport of toxic dinoflagellate cysts via ship's ballast water. Mar.Poll.Bull. 22: 27-30. 
Hallegraeff, G., Bolch, C.J., Blackburn, S.I., Oshima, Y. (1991). Species of the toxigenic dinoflagellate genus Alexandrium in southeastern Australian waters. Botanica Marina 34: 575-587.

Hallegraeff, G., and Bolch, C.J. (1992). Transport of toxic dinoflagellate cysts via ship's ballast water: implications for plankton biogeography and aquaculture. J. Plankton Res. 14: 1067-1084.

Hayhome, B.A., Anderson, D.M., Kulis, D.M., Whitten, D.J. (1989). Variation among congeneric dinoflagellates from the northeastern United States and Canada I. Enzyme electrophoresis. Mar. Biol. 101: 427-435.

Holton, T.A., Graham, M.W. (1991). A simple and efficient method for direct cloning of PCR products using ddT tailed vectors. Nuc.Acids Res. 19:1156.

Lenaers, G., Maroteaux, L., Michot, B., Herzog, M. (1989). Dinoflagellates in evolution. A molecular phylogenetic analysis of large subunit ribosomal RNA. J. Mol. Evol. 29:40-51.

Lenaers, G., Scholin, C. A., Bhaud, Y., Saint-Hilaire, D., Herzog, M. (1991). A molecular phylogeny of dinoflagellate protists (Pyrrhophyta) inferred from the sequence of the 24S rRNA divergent domains D1 and D8. J. Mol. Evolu. 32:53-63.

Marchuck, D., Drumm, M., Saulino, A., Collins, F. (1991). Construction of $\mathrm{T}$ vectors, a rapid and general system for direct cloning of unmodified PCR products. Nucl.Acids Res. 19:1154.

Mitchot, B., Hassouna, N., Bachellerie, J.P. (1984). Secondary structure of mouse 28S rRNA and general model for the folding of the arge RNA in eukaryotes. Nuc.Acids Res. 12::4259-4279.

Mitchot, B., Bachellerie, J.P. (1987). Comparisons of large subunit rRNAs reveal some eukaryote-specific elements of secondary structure. Biochimie 69:11-23.

Olsen, G.J. (1988). Phylogenetic analysis using ribosomal RNA. Meth. Enzymol. 164:793-812. 
Saiki, R.K., Gelfand, D.H., Stoffel, S., Scharf, S.J., Higuchi, R., Horn, G.T., Mullis, K.B., Erlich, H.A. (1988). Primer-directed enzymatic amplification of DNA with a thermostable DNA polymerase. Science 239:487-491

Sako, Y. (1992). Molecular definition and detection of toxic-harmful phytoplankton species. In: Smayda, T.J., Shimizu, Y. (eds.) Fifith international conference on toxic marine phytoplankton. Elsevier, New York (in press).

Sako, Y., Adachi, M., Ishida, Y. (1992). Preparation and characterization of monoclonal antibodies to Alexandrium species. In: Smayda, T.J., Shimizu, Y. (eds.) Fifith international conference on toxic marine phytoplankton. Elsevier, New York (in press).

Sako, Y., Kim, C.H., Ninomiya, H., Adachi, M., Ishida, Y. (1990). Isozyme and cross analysis of mating populations in the Alexandrium catenella/tamarense species complex. In: Graneli, E., Sundstrom, B., Edler, L., Anderson, D.M. (eds) Toxic Marine Phytoplankton. Elsevier, New. York, pp. 320-323.

Scholin, C.A. and D.M. Anderson (1992). Population analysis of toxic and non-toxic Alexandrium species using ribosomal RNA signature sequences. In: Smayda, T.J., Shimizu, Y. (eds.) Fifith international conference on toxic marine phytoplankton. Elsevier, New York (in press).

Scholin, C.A., Anderson, D.M., Sogin, M. (submitted). The existence of two distinct small-subunit rRNA genes in the toxic

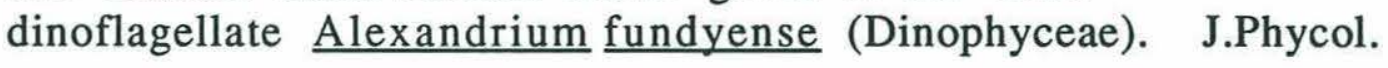

Sogin, M.L. (1990). Amplification of ribosomal RNA genes for molecular evolution studies. In : Innis, M.A., Gelfand, D.H., Sninsky, J.J., White, T.J. (eds.). PCR protocols: A Guide to Methods and Applications. Academic Press, pp 307-314.

Steidinger, K.A., and Moestrup, Ø. (1990). The taxonomy of Gonyaulax, Pyrodinium, Alexandrium, Gessnerium, Protogonyaulax and Goniodoma. In: Graneli, E., Sundstrom, B., Edler, L., Anderson, D.M. (eds) Toxic Marine Phytoplankton. Elsevier, New York, pp. 522-523. 
Swofford, D.L. (1991). PAUP: Phylogenetic analysis using parsimony, version 3.0s. Computer program and documentation distributed by the Illinois Natural History Survey, Chapaign, Illinois.

Taylor, F.J.R. (1984). Toxic dinoflagellates: taxonomic and biogeographic aspects with emphasis on Protogonyaulax. In: Ragelis, E.P. (ed.) Seafood Toxins. Amer. Chem. Soc. Symp. Series No. 262, Washington, D.C. pp. 77-97.

Taylor, F.J.R. 1985. The taxonomy and relationships of red tide dinoflagellates. In Anderson, D.M., White, A.W., and Baden, D.G. (eds.) Toxic Dinoflagellates. Elsevier, New York, pp. 11-26.

Wiley, E. O., Siegel-Causy, D., Brooks, D.R., Funk, V.A. (1991). The complete cladist. A primer of phylogenetic procedures. The University of Kansas Museum of Natural History special pulication No. 19. 158 pp. 
128 


\section{Chapter 4}

\section{Towards an Understanding of the Evolution and Global Dispersal of Toxic Dinoflagellates within the Alexandrium tamarense/catenella/fundyense "Species Complex"}




\section{ABSTRACT}

Ribosomal DNA (rDNA) sequence data were used to evaluate theories accounting for the evolution, global population structure and dispersal of toxic dinoflagellates within the Alexandrium tamarense, $\underline{\mathrm{A}}$. catenella and $\underline{\mathrm{A}}$. $\underline{\text { fundyense }}$ "species complex." Phylogenetic analysis indicates that members of endemic populations are genetically similar, regardless of their species designation. These patterns are consistent with a monophyletic radiation of these organisms from a common ancestor that included, or gave rise to, multiple morphotypes. Geographically-separated populations potentially underwent genetic divergence as a result of prolonged isolation (vicariant speciation), while retaining an overall conservative morphology. Recent dispersal may be indicated by genetic heterogeneity within a geographic region. Insufficient data preclude rigorous consideration of all possible evolutionary and dispersal scenarios; the hypotheses that are presented are intended to serve as a framework for future investigations of the evolution and population movements of $\underline{A}$. tamarense/catenella/ $\underline{\text { fundyense. }}$.

Alexandrium tamarense/catenella/ $\underline{\text { fundyense }}$ appear to be endemic to both eastern and western North America; plate tectonic and paleoclimatic events in the Arctic region may have played a role in this distribution. Alexandrium tamarense potentially dispersed from North America or northern Asia to Japan; this could have occurred by natural and/or human-mediated means, either millions of years ago or in the last 50-100 years. Similarly, $\underline{A}$. catenella 
appears to have been recently introduced to Australia from an Asian source population, though a natural introduction cannot be ruled out. Ballast water samples taken from ships entering Australian ports provide undeniable proof that human-assisted dispersal of $\underline{\mathrm{A}}$. tamarense/catenella cysts (resting spores) is occurring, and could be responsible for introducing genetically-distinct, morphotypicallysimilar organisms to a new locations. Determining the timing of dispersal events is problematic if based strictly on rDNA sequence similarities, since these molecules undergo change on a scale of millions of years. 


\section{INTRODUCTION}

The geographic range of toxic dinoflagellates within the

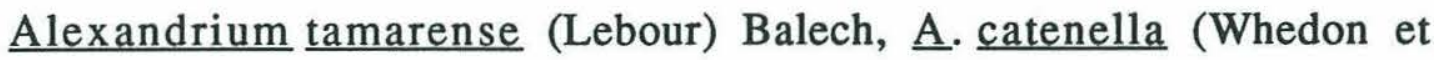
Kofoid) Balech and $\underline{\mathrm{A}}$. fundyense Balech "species complex" appear to be increasing on both regional and global scales (Anderson, 1989, Hallegraeff and Bolch 1991 and 1992). This is an alarming trend given that these organisms cause paralytic shellfish poisoning ("PSP"), a neurotoxic disorder with well-known public health and economic impacts (Steidinger and Baden 1984). Critical assessment of hypotheses put forth to explain the apparent dispersal (Anderson, 1989, Hallegraeff and Bolch 1992) have been hampered by an inability to identify endemic and introduced species, and thus to distinguish between a change in species' abundance (e.g., emergence from the "hidden flora;" Smayda 1990) versus a recent, natural or human-mediated introduction. In this chapter, hypothetical models accounting for the evolutionary history of the A.tamarense/ catenella/fundyense complex are considered in the context of these organisms' ribosomal RNA (rRNA) gene sequences (rDNA), in an effort to differentiate between "endemism" and "dispersal." Insufficient data preclude rigorous consideration of all possible evolutionary scenarios; the models that are presented are intended to serve as a framework for future investigations.

Part of the difficulty in defining the population structure of $\underline{\mathrm{A}}$. tamarense, $\underline{A}$. catenella and $\underline{A}$. fundyense stems from an international disagreement concerning the definition of "species." 
Some authorities believe that the detailed features used to define the tamarensoid, catenelloid and fundyensoid morphotypes are valid species criteria, while others contend that these organisms are morphological variants of the "same species," or "strains" of a single species (Balech 1985, Balech and Tangen 1985, Fukuyo 1985, Taylor 1985, Cembella and Taylor 1986, Cembella et al. 1987, 1988, Hayhome et al. 1989, Sako et al. 1990). A number of laboratories throughout the world have have attempted to settle the taxonomic debate by comparing those groups defined by "morphotype" (the phenotypic expressions of multiple genes) to groups defined by "genotype" (sub-cellular biochemical and genetic characteristics). The hope was that the validity of species designations could be more objectively evaluated in light of morphologically-independent measures of genetic variation. Biochemical criteria such as isozyme electrophoretic patterns, toxin composition analyses and cell surface antigens have been used to characterize isolates of the three morphospecies (Cembella et al. 1987, 1988, Hayhome et al. 1989, Sako 1992, Sako et al. 1990, 1992). However, the observed relationships between "morphotype" and "genotype" are not consistent: in some cases, morphospecies designations are congruent with groups defined by biochemical means (Sako et al. 1990; Sako 1992), but in other cases they are not (Cembella and Taylor 1986; Cembella et al. 1987, 1988; Hayhome et al 1989). Thus, results of sub-cellular characterizations used in an attempt to settle the morphotaxonomic debate are in conflict. To complicate matters further, the genetic affinities of organisms classified as the same morphospecies, but inhabiting different parts of the world, are 
largely unknown. Consequently, many questions concerning the population structure and suspected movements of $\underline{\mathrm{A}}$. $\underline{\text { tamarense/ }}$ catenella/fundyense remain unanswered.

In an effort to build a data base useful in addressing these questions, the sequence analysis of small subunit (Ss) and large subunit (Ls) rDNA was undertaken (Chapts. 1-3). A collection of $\underline{\mathrm{A}}$. $\underline{\text { tamarense, }} \underline{\mathrm{A}}$. catenella and $\underline{\mathrm{A}}$. $\underline{\text { fundyense }}$ isolated from North America, Western Europe, Japan, Australia, Tasmania, Thailand and the ballast water of several cargo vessels were compared on the basis of a restriction fragment length polymorphism (RFLP) assay of SsrDNA (Chapt. 2), and sequence analysis of a fragment of LsrDNA (Chapt. 3). The RFLP assay was used to detect a SsrDNA pseudogene (the "B gene;" Chapt. 1), and the LsrDNA sequences were used to construct a phylogenetic tree. The LsrDNA phylogeny indicates that the $\underline{A}$. tamarense/catenella/fundyense species complex is composed of at least five genetically-distinct strains, or "ribotypes." The LsrDNA ribotypes were named with reference to the geographic origin of the isolates: "North American," "Western European," "Temperate Asian," "Tasmanian" and "Tropical Asian." The SsrDNA B gene appears to occur exclusively in members of the North American ribotype. The LsrDNA ribotypes and the SsrDNA B gene appear to be useful biogeographic markers (Chapts. 2 and 3). However, the strict association of the B gene with only a single LsrDNA ribotype is tenuous since the SsrDNA RFLP assay samples only a few characteristic nucleotides of the B sequence; it is possible sequences similar to the B gene ("B-like genes") occur in other ribotypes but 
were missed in initial screens (Chapt. 2). In this chapter, the possible existence of B-like genes is addressed experimentally, and the utility and limitations of using rDNA sequences as indicators of Alexandrium population heterogeneity and dispersal are examined in greater detail.

\section{RESULTS}

A phylogeny of selected LsrDNA sequences from globallydistributed members of the $\underline{A}$. tamarense/catenella/fundyense complex (Table 1) is shown in Fig. 1. The sequences used in this analysis are presented in Chapt. 3. It was possible to reduce the previous alignment by four positions when the organisms listed in Table 1 were considered alone.

The relationship between LsrDNA ribotypes and the B gene were clarified by direct sequencing of polymerase chain reaction(PCR-; Saiki et al. 1988) amplified SsrDNA from isolates representing the North American, Western European, Temperate Asian and Tasmanian ribotypes (Fig. 1 and Table 1). Examples of the sequences are presented in Fig. 2. The region examined (positions $\sim 636$ to 1158; cf. Chapt. 1) includes both evolutionarily-variable as well as evolutionarily-conserved sequences (Sogin and Gunderson 1987), and is bracketed by restriction sites used in the $A / B$ restriction tests. In addition, this part of the molecule encompasses multiple nucleotide differences in the A and B sequences. Seven transversions, four transitions and three single base length 
differences in the two genes from the North American $\underline{A}$. fundyense were visualized; none of the other isolates examined showed any evidence for these ambiguities and length heterogeneities, or others indicative of two or more distinct SsrDNAs. When results of this sequencing are combined with portions of the molecules sampled in the $\mathrm{A} / \mathrm{B}$ gene restriction tests (Chapt. 2), a total of 17 positions differentiating the $\mathrm{A}$ and $\mathrm{B}$ sequences have been sampled for each of the isolates examined.

Figure 1. Most parsimonious phylogenetic tree inferred from selected Alexandrium tamarense/catenella/fundyense, and $\underline{\mathrm{A}}$. affine LsrDNA sequences using PAUP 3.0 (Swofford, 1991; cf. Chapt. 3 (alignment used is reduced four positions from that shown in Chapt. 3)]. Branch lengths reflect the relatedness of the sequences (e.g., G. Hope 1 and G. Crux differ by one nucleotide). "North American," "Western European," "Temperate Asian," "Tasmanian" and Tropical Asian" are proposed ribotype designations given to terminal taxa. Toxic isolates are denoted by "*." Ensemble statistical indices are as follows: consistency index (CI) excluding uninformative characters $=0.841$; homoplasy index $(\mathrm{HI})$ excluding uninformative characters $=0.159$; retention index $(\mathrm{RI})=0.958$; rescaled consistency index $(R C)=0.850$ (cf. Swofford 1991). SsrDNA characteristics for the cultures are shown on the appropriate branches; note the correspondence between the B gene and "North American" ribotype. Alexandrium affine is defined as the outgroup since its SsrDNA restriction pattern [Hae(1) RFLP; cf. Chapt. 2] is divergent relative to all representatives of the $\underline{\mathrm{A}}$. tamarense/catenella/ fundyense complex. 


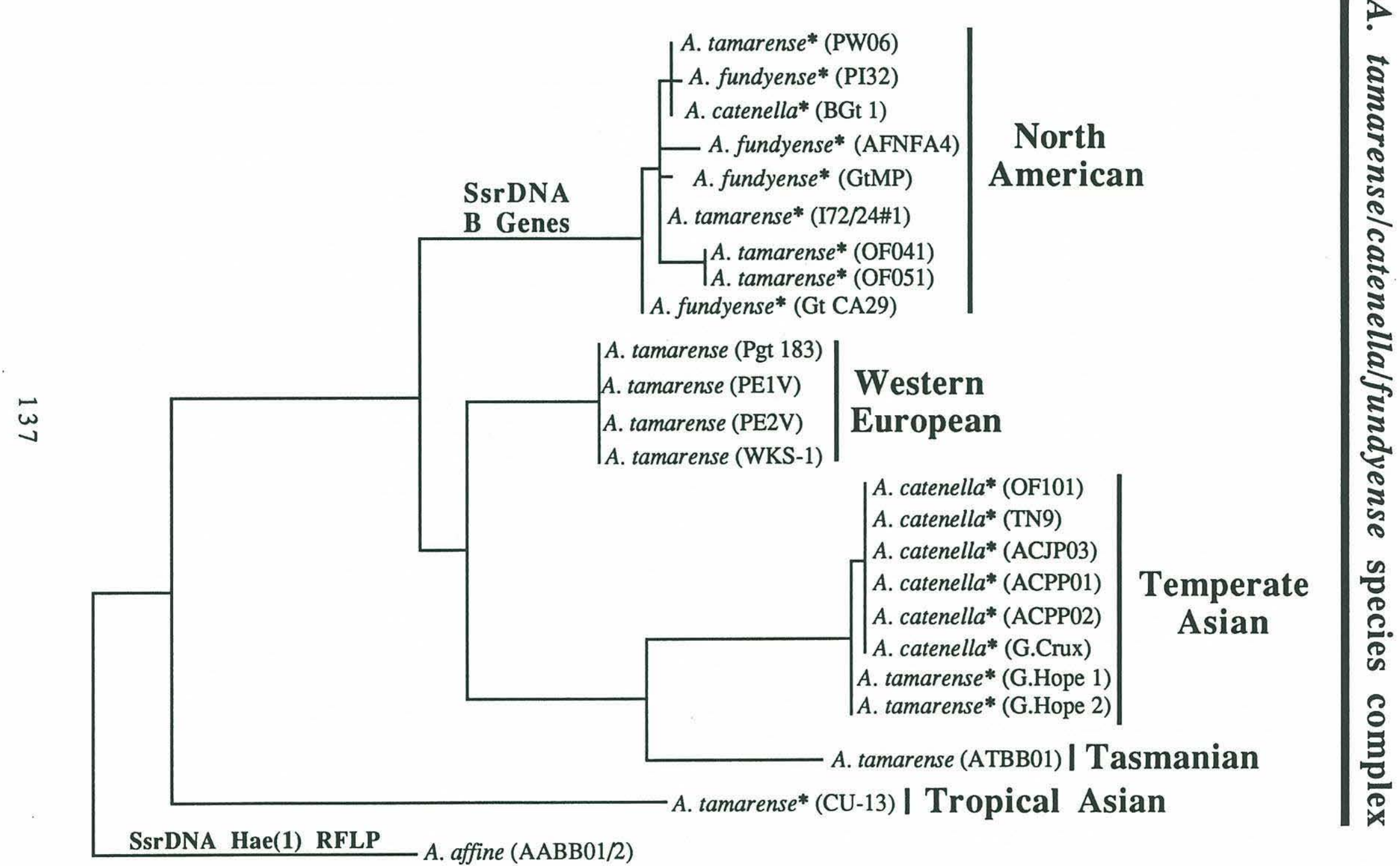


Table 1. Comparison of geographic regions, and isolated Alexandrium species along with their toxicity and rDNA characteristics.

\begin{tabular}{|c|c|c|}
\hline \multicolumn{2}{|c|}{ Geographic Region } & $\begin{array}{c}\text { Isolation } \\
\text { Locale }\end{array}$ \\
\hline $\begin{array}{l}\text { North } \\
\text { America }\end{array}$ & $\begin{array}{l}\text { W. Coast } \\
\text { E. Coast }\end{array}$ & $\begin{array}{l}\text { Port Benny, Alaska } \\
\text { Porpoise Isl., Alaska } \\
\text { Russian River, CA } \\
\text { Newfoundland } \\
\text { Cape Ann, MA } \\
\text { Orleans, MA }\end{array}$ \\
\hline
\end{tabular}

\begin{tabular}{l}
\multicolumn{1}{c}{ Isolated } \\
Species \\
\hline A. tamarense \\
A. fundyense \\
A. catenella \\
A. fundyense \\
A. fundyense \\
A. fundyense
\end{tabular}

A. tamarense

A. tamarense

A. tamarense

Spain $\mid \begin{aligned} & \text { Galicia, Spain } \\ & \text { Galicia, Spain }\end{aligned}$

Europe

Japan

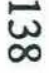

\section{Thailand | Gulf of Thailand}

Australia $\mid$ mainland $\mid \begin{aligned} & \text { Port Phillip, Australia } \\ & \text { Port Phillip, Australia }\end{aligned}$ Tasmania| Bell Bay, Tasmania

\begin{tabular}{l|l} 
Ballast Water & $\begin{array}{l}\text { Muroran, Japan (N) } \\
\text { Kashima, Japan (S) } \\
\text { Singapore? }\end{array}$ \\
Samchonpo, S. Korea e \\
Samchonpo, S. Korea
\end{tabular}

A. tamarense

A. tamarense

A. catenella

A. catenella

A. tamarense

A. catenella

A. tamarense

A. catenella

A. catenella

A. tamarense

A. tamarense

A. catenella

A. catenella

A. tamarense

A. tamarense

\begin{tabular}{l} 
Strain $^{\text {a }}$ \\
\hline PW06 \\
PI32 \\
BGt 1 \\
AFNFA4 \\
Gt CA29 \\
GtMP
\end{tabular}

\begin{tabular}{|c|c|}
\hline Toxic? & B Gene? \\
\hline yes & yes \\
\hline yes & yes \\
\hline yes & yes \\
\hline yes & yes \\
\hline yes & yes \\
\hline yes & yes \\
\hline
\end{tabular}

Pgt183

PE1V

PE2V

OF041

OF051

OF101

TN-9

WKS-1

WKS-8

\section{CU13}

ACPP01

ACPP02

ATBB01

no

no*

no

\section{no}

no

no

yes yes

yes yes

yes

yes

yes

yes

yes

no

no

no

no

no

yes

yes

no*

yes

I72/21 \#4 yes

$\mathrm{ACJP} 03$ yes

G. Crux yes

G. Hope 1 yes

G. Hope 2 c

North American (western)

North American (western)

North American (western)

North American (eastern)

North American (eastern)

North American (eastern)

Western European

Western European

Western European

North American (alternate)

North American (alternate)

Temperate Asian (Japanese)

Temperate Asian (Japanese)

Temperate Asian (Japanese)

Western European

Tropical Asian

no Temperate Asian (Japanese)

no Temperate Asian (Japanese)

no Tasmanian

yes North American (eastern)

no Temperate Asian (Japanese)

no Temperate Asian (Japanese)

no Temperate Asian (Korean)

no Temperate Asian (Korean)

a) strain listings currently used in the D.M. Anderson culture collection

b) determined by mouse bioassay and/or HPLC analysis;" "*" may produce trace amounts of toxin (D. Kulis, pers. comm.)

c) as defined by the SsrDNA A/B restriction test (see Chapter 2)

d) designations given to LstDNA phylogenetic tree termini (see Chapter 3 and Appendix C)

e) presumed origin (Hallegraeff and Bolch 1992)

f) hailing port of vessel - origin of ballast water uncertain (Hallegraeff and Bolch 1992) 


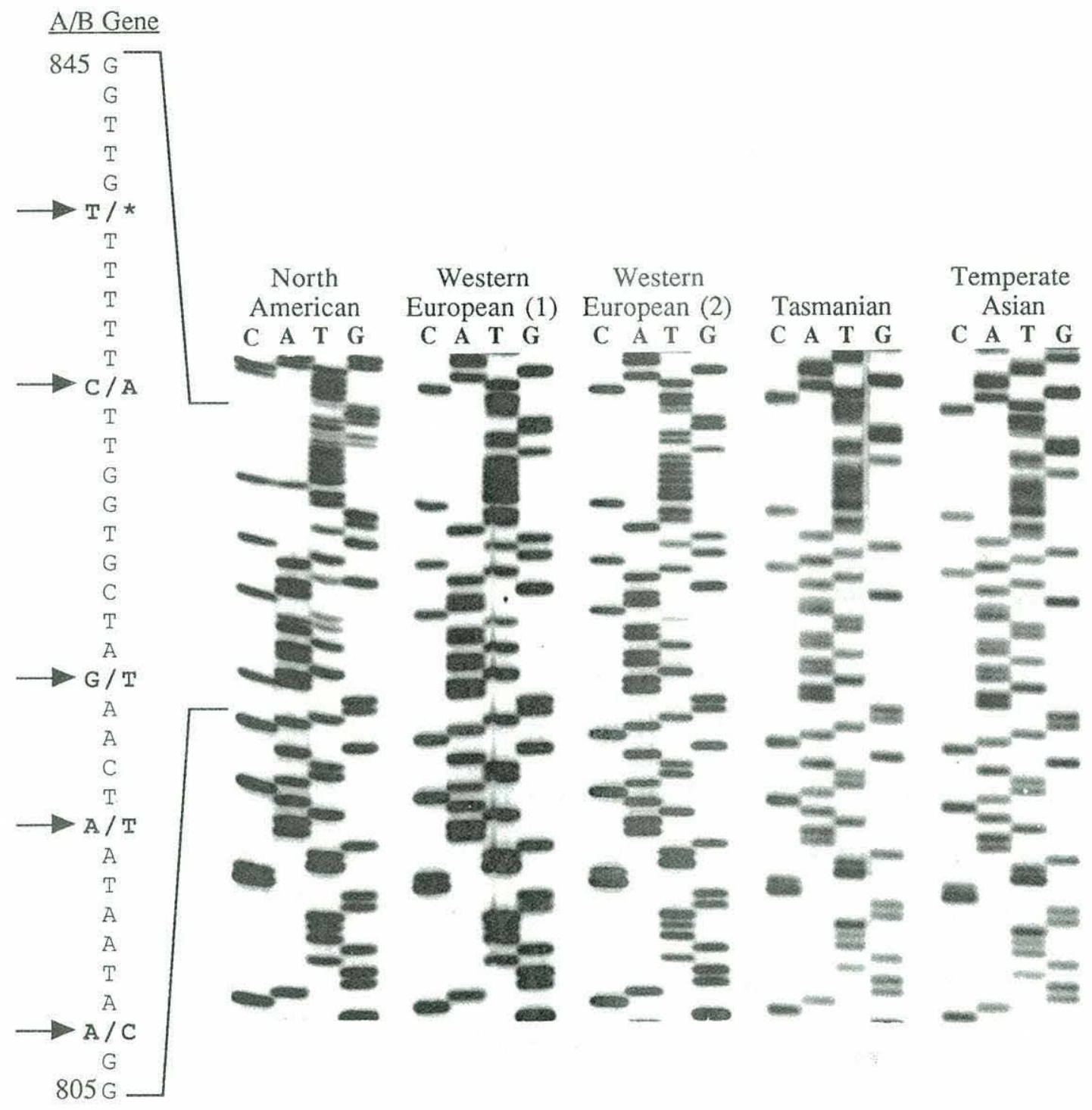

Figure 2. Direct sequencing of PCR-amplified SsrDNA from North American (A. fundyense; GtCA29), Western European [A. tamarense; Pgt 183 (1) and PE1V (2)], Tasmanian (A. tamarense; ATBB01/2) and Temperate Asian ( $\mathbf{A}$. catenella; ACPP01) representatives using the magnetic bead technique. Two Western European isolates were included because " 1 " is non-toxic, while " 2 " may produce trace amounts of toxin. Partial sequences of the A and B genes from GtCA29 (positions 805-845) and their correspondence to that sequencing ladder are also shown; arrows denote ambiguities and a single base length heterogeneity $(\mathrm{T} / *)$ expected if both genes are present. 


\section{DISCUSSION}

There are several possible explanations for the apparent dispersal of $\underline{A}$. tamarense/catenella/fundyense: increased abundance or visibility of endemic species; natural dispersal; human-assisted dispersal; or, a combination of all the above (Anderson 1989, Smayda 1990, Hallegraeff and Bolch 1991). In order to distinguish between these hypotheses, endemic and introduced flora must differentiated. Historical records of toxicity and species' abundance in a region are useful in this regard, yet an absence of these indicators does not preclude the possibility that toxigenic Alexandrium are present in a given area. A further difficulty is that A. tamarense/catenella/ $\underline{\text { fundyense }}$ resting cysts survive for $5-10$ years at most in sediments (Keafer et al. 1992). Fossilization of these cysts, if it occurs, would be of little use since it would be difficult to assign such non-descript cysts walls to one of these organisms (Taylor, 1980). Since stratigraphy cannot be used to determine the

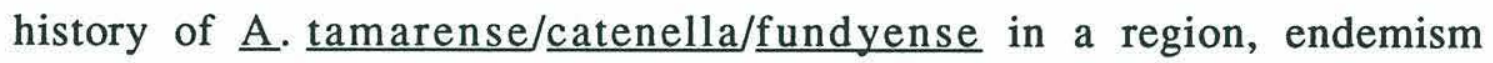
and dispersal must be inferred from other data.

Patterns of indigenous and introduced flora may be deduced by defining the phylogenetic relationships of their populations, and by viewing the resulting continuities or discontinuities in the context of geography and the historic record (Brooks and McLennan 1991). In an attempt to do this for the $\underline{A}$. tamarense/catenella/fundyense complex, rDNA sequences from globally-distributed isolates were compared (Chapt. 2 and 3). The LsrDNA ribotypes and SsrDNA B 
gene do appear to ascribe specific populations, and some dispersals seem evident, but several hurdles remain before the rDNA data can be rigorously applied to substantiate these findings: first, an evolutionary model is needed to account for the confusing associations between morphotypes, ribotypes and geographic populations; and second, the B gene's relationship to the LsrDNA phylogeny must be further characterized, to determine if B-like genes were missed in the RFLP screening procedure.

In the discussion that follows, two hypothetical evolutionary schemes for the A. tamarense/catenella/fundyense complex are considered in the context of the organisms' SsrDNA and LsrDNA sequence characteristics. Based on the sequence data, one of the models is favored, and used as a background to explore the possibility of using rDNA sequnces to detect A. tamarense/catenella/ fundyense dispersal. Note that other models explaining patterns of A. tamarense/catenella/fundyense population heterogeneity can be envisioned, but are not discussed. It is hoped that this treatise will simply serve as food-for-thought, for future investigations of the evolution and population movements of A.tamarense/catenella/ fundyense.

Evolution of the Alexandrium tamarense/catenella/fundyense Complex

Gonyaulacoid dinoflagellates, a group that encompasses Alexandrium species, are apparent in the fossil record from at least 
the Cretaceous [ 135 million years ago (Ma)] onward. A more precise estimate of the appearance of $\underline{\mathrm{A}}$. tamarense, $\underline{\mathrm{A}}$. $\underline{\text { catenella }}$ and $\underline{\mathrm{A}}$. fundyense in particular is not possible because of a paucity of fossil data (Taylor, 1980). Nevertheless, it is reasonable to assume that these organisms arose at least tens of millions of years ago, possibly even longer (Taylor, 1980 and pers. comm.). Clearly, these species have had ample evolutionary time to colonize many regions of the world (Taylor, 1984 and 1987).

Hallegraeff and Bolch (1992) have noted that $\underline{\text { A.tamarense/ }}$ catenella/fundyense, as well as many other meroplanktonic dinoflagellates, would not survive for long periods of time in the open sea; transoceanic dispersal by means of ocean currents is highly improbable. Endemic populations of Alexandrium would therefore have arisen as result of a slow "migration" of organisms along coastlines of spreading continents, or perhaps on very rare occasions by chance encounters with migratory water birds (or other such episodic events). Ultimately, population dispersal to geographicallyremote locations would result in millions of years of genetic isolation.

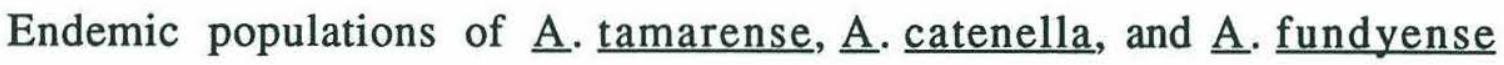
are thus predicted to have arisen as a result of vicariance (i.e., geographic isolation; Brooks and McLennan 1991). Each population should be genetically-distinct, owing to the processes of "genetic drift" (i.e., neutral mutation) and selection (Ayala and Kiger 1980).

Present day morphological and genetic affinities of $\underline{A}$. tamarense/catenella/fundyense populations could depend on 
whether these species are descended from multiple, geneticallydistinct forms that converged on a similar morphotypes ("polyphyletic convergence"), or if they radiated from a single ancestor that included, or gave rise to, multiple morphotypic forms ("monophyletic radiation"). These two models and and their respective phylogenetic predictions are shown in Fig. 3. In both cases, endemic populations may contain one or more of the morphospecies, and be genetically-distinct, regardless of morphotype. However, if the progenitors of $\underline{\mathrm{A}}$. tamarense, $\underline{\mathrm{A}}$.

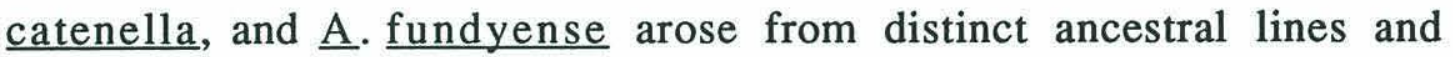
subsequently converged on a similar morphology, then the different morphospecies should always be distinguishable at a subcellular level, even when they co-occur; their combined phylogeny should reflect the evolution of morphospecies, not populations (Fig. 3a). Alternatively, if $\underline{A}$. tamarense/catenella/fundyense morphospecies arose from a common ancestor that included or gave rise to several morphotypes, then co-occurring morphotypes should be similar with regards to sub-cellular characteristics, irrespective of their morphospecies designations. In this case, their phylogeny should resolve geographically-distinct populations ("strains"), that may or may not share the same morphotype(s) (Fig. 3b). 1, 2 Recent dispersals (e.g., within the last 50 years) are expected to confuse the pattern of morphotypes, ribotypes and geographically-isolated

1 these predictions have also been considered in the context of sexual compatibilities (Chapt. 6), but are beyond the scope of the present discussion.

2 the models presented in Fig. 2 assume no lateral gene transfer, however, such considerations have been given elsewhere (Chapt. 6). 


\section{Polyphyletic Convergence}

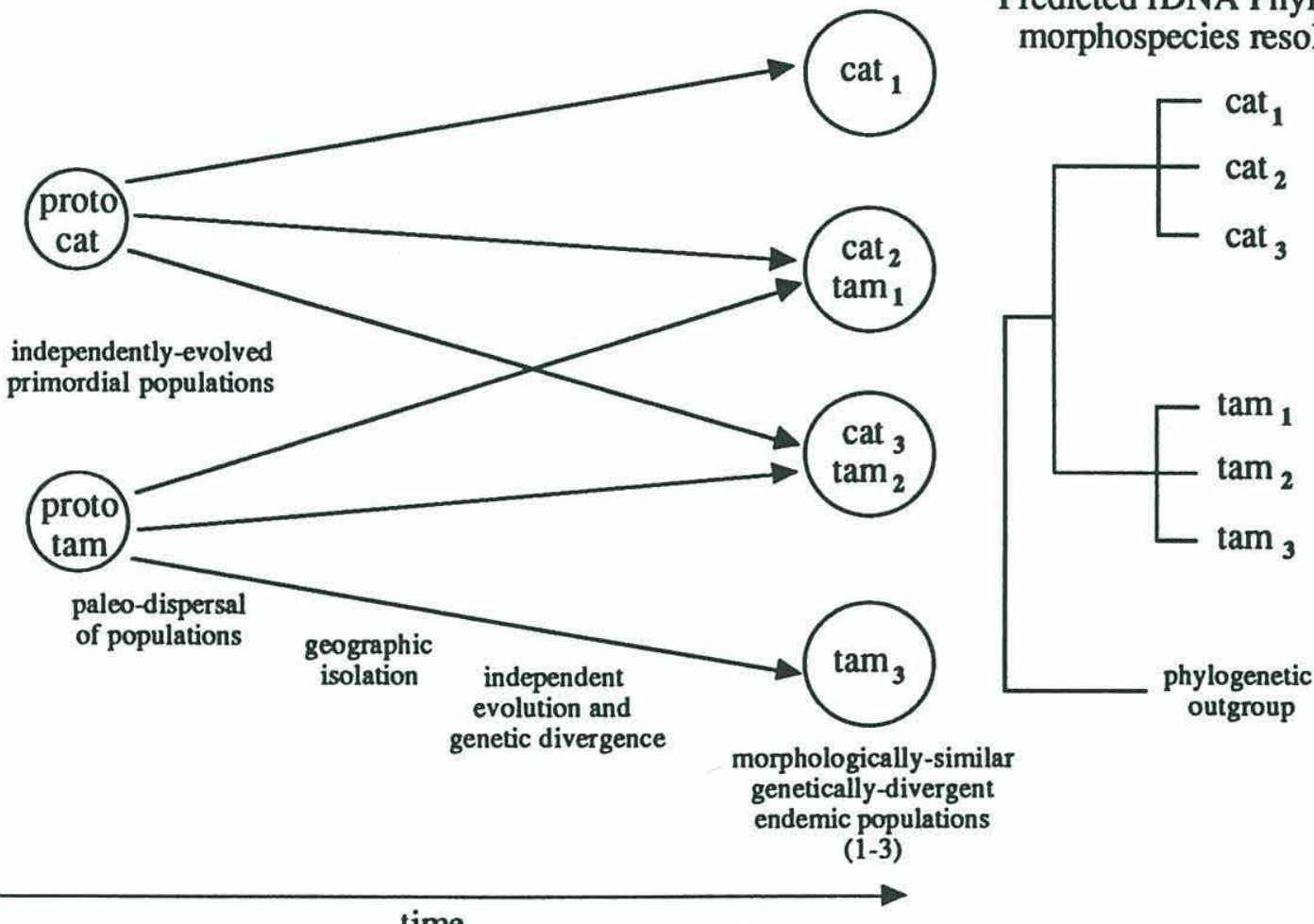

time

Figure 3. Hypothetical models accounting for the evolution of the $A$. tamarense/catenella/fundyense species complex, and their respective phylogenetic predictions. For simplicity, the models consider only catenelloid ("cat") and tamarensoid ("tam") morphotypes. Primordial populations of A. catenella/tamarense ("protocat" and "prototam," respectively) are presumed to have dispersed to various regions of the world and to have undergone genetic divergence as a result of vicariance. Ultimately, the dispersed organisms are expected to have given rise to morphologicallysimilar, genetically-divergent populations (the resulting regional populations are represented as circles; populations of each morphospecies are numbered 1-3). Present-day phylogenetic relationships of the two morphospecies, and their correspondence to geography are predicted to depend on: (a) whether the the organisms arose from distinct ancestral lines that converged on a similar morphology ("Polyphyletic Convergence"); or, (contd. on next page) 


\section{Monophyletic Radiation}

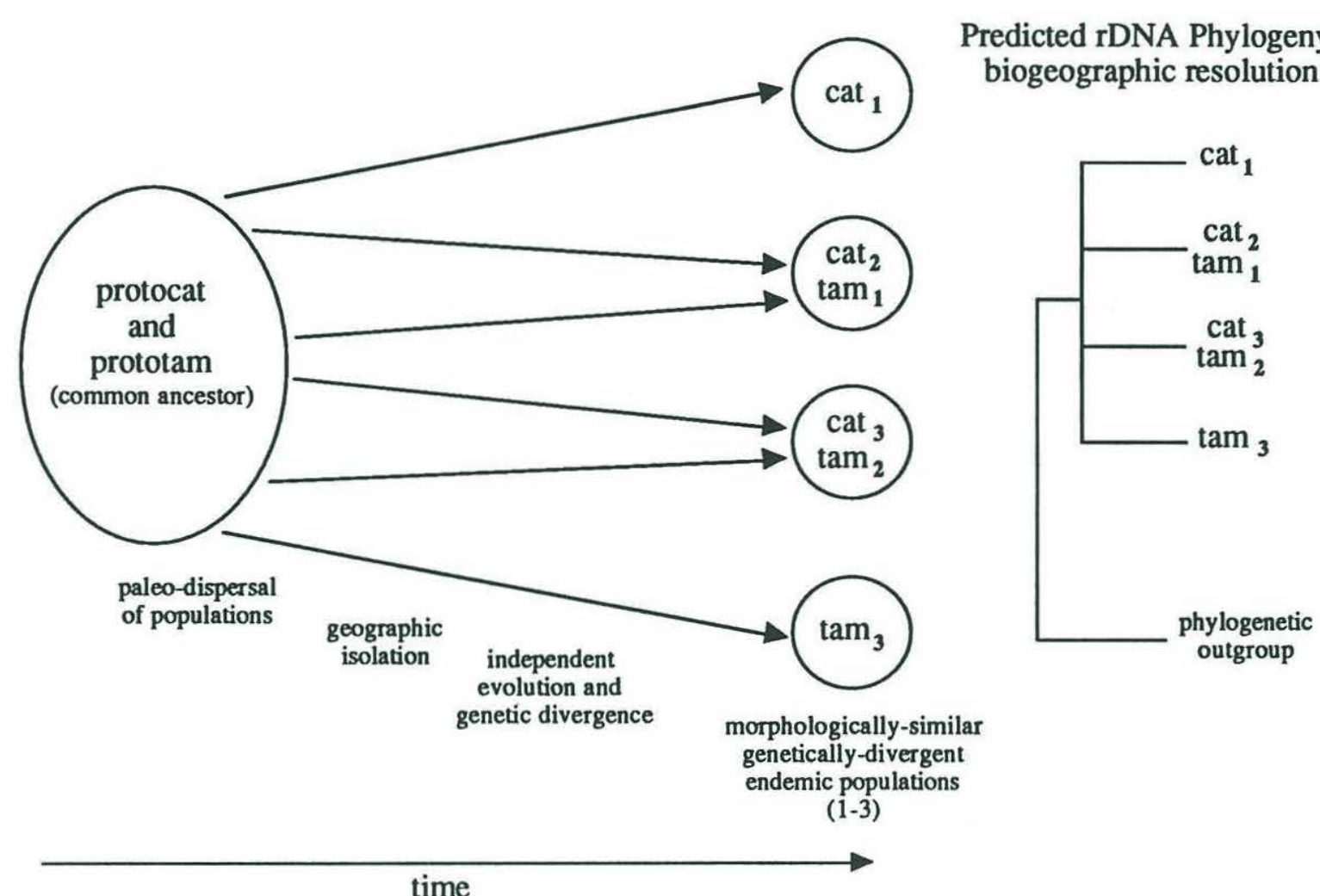

Figure 3. contd. (b) whether the the organisms radiated from a common ancestor ("Monophyletic Radiation"). Hypothetical rDNA phylogenetic trees illustrate the expected outcomes for each model. In both cases, endemic populations are predicted to be distinguishable. However, a polyphyletic convergence predicts that the overall tree topology resolves morphospecies, and that the two morphospecies should appear genetically-divergent even when they co-occur. In contrast, a monophyletic radiation predicts that the overall tree topology resolves geographic populations, irrespective of morphotype. These predictions assume no lateral gene transfer; a geographic populations, irrespective of morphotype. These predictions assume no
consideration of this and the effects of sexual compatibilities are given in Chapt. 6. 
populations, and are one means by which dispersal could be inferred. (see below and Chapt. 3).

Sequence analysis of rDNA is one way to test these predictions. Ribosomal RNA genes are composed of both evolutionarily-conserved and evolutionarily-variable "domains" (Lenaers et al. 1988, 1989, Raue' et al., 1988, Sogin and Gunderson 1987). Conserved regions exhibit a reduced rate of nucleotide change, and are thus useful in comparing distantly-related taxa that may have diverged hundreds of millions of years ago. In contrast, hypervariable regions are subject to accelerated rates of nucleotide change, and as a result may ascribe genus, species, or even strain-specific genetic markers (Gobel et al. 1987, McCutchan et al. 1988, Guadet et al., 1989, Lenaers et al., 1991). Because of the rapidity with which hypervariable rDNA sequences change, they appear amenable to resolving evolutionary events that have occurred in the recent geologic past (e.g., 5-10 Ma), and therefore should be of utility in distinguishing between the evolutionary models presented in Fig. 3. The 5' portion of LsrDNA is useful in this regard as it encompasses the so-called D1 and D2 hypervariable domains, some of the most most rapidly evolving portions of eukaryotic rDNA, interspersed among more highly conserved sequences (Mitchot et al. 1984, Mitchot and Bachellerie 1987, Guadet 1989, Lenaers et al., 1989, 1991). The phylogenetic tree shown in Fig. 1 is based on a sequence analysis of this fragment (Chapt. 3), and is most consistent with the monophyletic radiation model. This conclusion is based on the facts that distinct, cooccurring morphospecies can have similar (or identical) LsrDNA 
ribotypes (e.g. North American $\underline{A}$. tamarense/catenella/ $\underline{\text { fundyense; }}$ Temperate Asian $\underline{A}$. tamarense/catenella), and that the overall tree topology is one of geographic resolution, not morphospecies resolution. Similar reasoning has been used to support vicariant speciation patterns among a variety of other organisms (cf. Brooks and McLennan 1991; Lynch 1989).

Patterns indicative of dispersals of Alexandrium species appear evident. In Japan, for example, North American, Western European and Temperate Asian ribotypes all co-occur. As noted above, recent dispersal events should confuse the patterns of morphotypes, genotypes and their relationship to geography, and such is the case for Japanese isolates of $\underline{\mathrm{A}}$. tamarense and $\underline{\mathrm{A}}$. catenella. However, determining the timing and mode of these potential dispersals requires additional information and can be problematic (see below).

The B gene's biogeographic distribution (Table 1) also supports a monophyletic origin of the $\underline{\mathrm{A}}$. tamarense/catenella/ $\underline{\text { fundyense }}$ complex, as well as claims of population movements. First, the B gene is found in all three species, a result consistent with these organisms' origin from a single, common ancestor. Second, the B gene is associated with only a single LsrDNA ribotype ("North American"). This indicates that the B gene and only one of the LsrDNA sequence types share a common evolutionary history; that is, ascribe one of the hypothesized geographically-isolated, "endemic populations" (Fig. $3 b)$. Third, the B gene has been found in all North America isolates, but only in a fraction of those from Japan. This indicates a dispersal 
of B gene-containing A. tamarense from North America to Japan. However, the strengths of these supporting observations, rest on the supposition that the $B$ sequence is in fact a genetic marker that is unique with respect to other evolutionary lineages (endemic populations) of $\underline{A}$. tamarense and $\underline{A}$. catenella throughout the world.

Evolution of the B Gene: Morphospecies and Population Specificity

Their are several conflicting hypotheses concerning the relative age of the B gene and its population specificity, two of which are considered here:

1) The B gene appeared "late" in the evolutionary history of

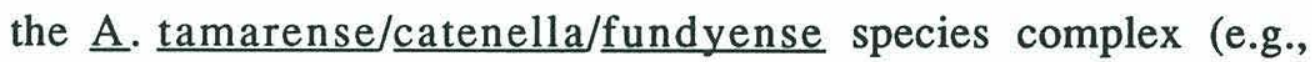
within the last several million years), and is a unique, population-specific marker with a restricted geographic distribution.

2) The B gene appeared "early" in the evolutionary history of

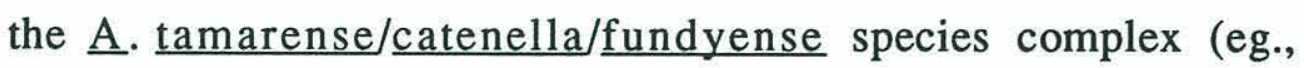
tens of of millions of years ago or more), and is widelydistributed in populations inhabiting different regions of the world.

In light of the LsrDNA phylogeny (Fig. 1), the first hypothesis predicts that the $\mathrm{B}$ gene is unique to the North American ribotype, and is a specific marker for organisms with a North American origin 
(see below). In contrast, the second hypothesis predicts that B-like genes are pandemic among geographically-isolated populations, and will occur in multiple ribotypes; the B gene's utility as an indicator of Alexandrium population heterogeneity may be greatly diminished.

Distinguishing between these possibilities required sampling other portions of the SsrDNA molecules not targeted in the original RFLP assay. Figure 2 illustrates an example of how this was accomplished. The A and B genes are clearly visible in the North American sequence, as seen by the ambiguities and length heterogeneities that result from both genes' presence. There is no indication that B-like sequences occur in the others. Therefore, the B gene cannot be an "ancient sequence" that has been differentially preserved in widely-distributed populations. It must have appeared "late" in the evolutionary history of the $\underline{A}$. tamarense/catenella/ fundyense complex [hypothesis (1)], and thus should be highly population-specific. Considering the B gene's known biogeographic distribution and the history of toxicity in North America and Japan (see below), it seems probable that B gene-containing $\underline{A}$. tamarense were introduced to Japan sometime in the recent past.

Endemism of North American $\underline{A}$. tamarense/catenella/fundyense

The first account of PSP poisonings in North America were documented in 1793 during Captain George Vancouver's exploration of present day British Columbia (Quayle 1969). Confirmed cases of PSP poisonings in eastern Canada pre-date 1889, however, as 
accounts of early explorers and settlers clearly indicate, Native Americans inhabiting eastern Canada had a traditional knowledge of the hazards associated with eating shellfish (Prakash et al. 1971). Taken together, these observations strongly suggests that PSP is endemic to eastern and western shores of North America. Further support for this comes from recent work reported by Kvitek (1992), demonstrating that certain species of clams occurring along western North America have evolved a resistance to PSP toxins, and apparently use the toxins as deterrents to predation. The evolutionary interplay between PSP toxins, clams, and predators of clams suggests that PSP's presence in North America dates back many millions of years (Taylor pers. comm.).

Though PSP has a long history in North America, it was not definitively ascribed to a specific organism on the east coast until 1961 (Prakash et al. 1971) and on the west coast until 1965 (Quayle 1969). The causative organisms in North America are now known as $\underline{\text { A. }}$ tamarense, $\underline{\text { A. }}$ catenella and $\underline{\mathrm{A}}$. $\underline{\text { fundyense }}$ (Steidinger and Moestrup 1990, Balech 1985). Alexandrium catenella are found exclusively on the west coast, and with one possible exception (strain PI32), A. fundyense is only found on the east coast. Alexandrium tamarense occurs on both coasts.

Since the early Mesozoic ( 250 Ma), the North American continent has been a barrier as well as a conduit for the paleodispersal of both terrestrial and marine organisms (Berggren and Hollister 1974, Marincovich et. al 1990, Thiede et al. 1990). The 
Arctic region is especially important when considering connections between the North Pacific and North Atlantic (Marincovich et. al 1990, Thiede et al. 1990). During the late Cretaceous ( 100 Ma), the Arctic ocean is believed to have had connections to the Pacific and Tethys seas, but by the end of the Cretaceous became almost completely isolated from each. A connection to North Atlantic is believed to have opened sometime during the Paleogene ( 40-50 Ma), providing the means for Atlantic fauna to enter the Arctic. The Pliocene opening of the Bering straight ( $\sim 3 \mathrm{Ma})$ produced the most dramatic change in the composition of Arctic marine organisms: North Pacific species flooded the Arctic, largely displacing other organisms of Atlantic origin, while a limited number of ArcticAtlantic species apparently entered the Pacific via the same seaway (Marincovich et. al 1990).

These geologic and paleo-oceanographic events took place when the Arctic climate was much milder than the present - the region was seasonally temperate and free of an ice cap (Berggren and Hollister 1974, Clark 1990, Marincovich et. al 1990, Thiede et al. 1990). In addition, the coming and going of seaways has occurred in a time frame that is relevant to the evolution and paleo-dispersal of $\underline{A}$. tamarense, $\underline{A}$. catenella and $\underline{A}$. $\underline{\text { fundyense: }}$ these organisms could have descended from Pacific, Tethyan or Atlantic realms, and multiple opportunities existed for them to become omnipresent from the Bering Straight to the Labrador sea. However, with the onset of polar ice formation ( 3 Ma), such a population could have become restricted to eastern and western North America. As a consequence, 
vicariant genetic divergence of these populations may have begun no later than several million years ago, and thus the B sequence must have appeared prior to, or at, this time.

Eastern and western North American isolates examined thus far share a very high degree of rDNA similarity, but can be distinguished on the basis of very fine-scale Ss and LsrDNA characteristics (Appendix C). This observation is consistent with the hypothesis that the divergence of these populations began within the last several million years. Furthermore, it suggests that the LsrDNA hypervariable D2 domain ( 300 base pairs in Alexandrium) may undergo only several nucleotide changes per million years. ${ }^{3}$ Thus, organisms originating from the same population, but completely isolated from each other for thousands, or even a million years, could still appear very similar with respect to their rDNA sequences. Using these sequences to interpret patterns of $\underline{\mathrm{A}}$. tamarense/catenella/ fundyense population heterogeneity and dispersal must therefore be done in the context of geologic time.

Possible Origins of Japanese $\underline{A}$. tamarense/catenella Heterogeneity

In contrast to North America, PSP toxicity was unknown in Japan until 1948 (Anraku 1984). Toxicity caused by $\underline{\text { A. tamarense }}$ and A. catenella in Japan was only confirmed in 1975 and 1976, respectively (Murano 1975, Hashimoto 1976). The recent

3 cf. Appendix C; the sequence variation between "eastern" and "western" B genes has not yet been determined. 
appearance of PSP in Japan is noteworthy, given the country's high consumption of seafood and extensive farming of local waters. The genetic heterogeneity of Japanese $\underline{A}$. tamarense/catenella (Fig. 1 and Table 1), and the relatively recent onset of PSP in Japan, indicate that these organisms are potentially descended from introduced species. As noted above, B gene-containing $\underline{A}$. tamarense are the most noteworthy in this regard. However, establishing the timing of dispersal(s) remains problematic given the rate at which rDNA sequences evolve. Of particular interest is a 1934 illustration by Oda of a Diplopsalis species that appears to be $\underline{A}$ tamarense (Hallegraeff, pers. comm.). If this description is indeed $\underline{\mathrm{A}}$. tamarense, the species was present prior to the first recorded PSP toxicity in Japan. Alexandrium tamarense could be one of the "hidden flora" whose growth has only recently been enhanced in Japanese waters.

The Oyashio current could have played a role in dispersing "North American A. tamarense" to Japan. The Oyashio is fed from water near the Bering Straight and Sea of Okhotsk, and flows southward along the Asian coast towards the northern-most Japanese islands, Hokkaido and Honshu (Pikard 1979, Kawai 1972). The Oyashio current is thought to have developed very early - and was certainly present after the opening of the Bering Straight (Luyendyk et al., 1972). Thus, it is possible that some of the socalled "North American A. tamarense" have dispersed with it from Alaska and northwestern Canada, and/or northern Asia. The projected path lies along the Asian coast and Kuril islands; a one-step transoceanic dispersal need not be invoked. Such a dispersal could 
have taken many thousands, if not several million years to occur. Because this is a relatively short period of time, these organisms could harbor the B gene and appear genetically-similar to contemporary populations of $\underline{A}$. tamarense/catenella/ $\underline{\text { fundyense }}$ found in North America.

Although natural dispersal of A. tamarense to Japan cannot be ruled out, there is good reason to believe that this organism has dispersed by human-assisted means over the last 50 years. For example, the exchange of shellfish stocks between British Columbia and Japan (Taylor, pers. comm.), and increased shipping between Japan and other countries of the world are potential mechanisms whereby such transfers could occur (Anderson 1989, Hallegraeff and Bolch 1992). In addition, some $\underline{A}$. tamarense found in Japan are identical to eastern North American and Western European isolates with respect to their SsrDNA and LsrDNA characteristics, as well as their ability to produce toxin (Chapter 3). Such identity is more consistent with a recent, human-assisted introduction than a natural dispersal millions of years ago. As the population structure of $\underline{A}$. tamarense/catenella/fundyense inhabiting North America, Asia and elsewhere become more rigorously defined and genetic variation within these populations documented, it may be possible to distinguish between these possibilities (cf. Chapt. 6). 
Dispersal of toxic Alexandrium Species to Australia

The history of PSP toxicity in Australia parallels that of Japan. In Australia, PSP-producing $\underline{A}$. catenella and $\underline{A}$. minutum were first confirmed in 1988 (Hallegraeff et al, 1988). Prior to that time, there is only a single account of suspected PSP toxicity (Le Messurier 1935), but the causative species was never identified (Hallegraeff et al. 1991). A taxonomic survey of Australian dinoflagellates published in 1954 (Wood 1954) does include a single record of a chain-forming species, Gonyaulax conjuncta, that may be a misidentified $\underline{\mathrm{A}}$. catenella. Thus, it is possible that $\underline{\mathrm{A}}$. catenella was present in Australia prior to 1988 (Hallegraeff et al. 1991). However, the recent appearance of conspicuous PSP toxicity in Australia, along with concomitant blooms of toxigenic dinoflagellates is noteworthy. Moreover, blooms in Australia have been found to occur within or adjacent to major shipping ports, areas where cargo ships routinely discharge ballast water that originates in foreign locations (Hallegraeff et al. 1991, Hallegraeff and Bolch 1992). Once again, one is confronted with difficulties distinguishing between the intuitivelyappealing mechanism of dispersal (in this case by ships' ballast water) and the ever-present possibility that a "hidden flora" is for some reason becoming a more visible part of the phytoplankton community. Sequence analysis of rDNA from Australian $\underline{A}$. $\underline{\text { tamarense }}$ and $\underline{A}$. catenella is one way these possibilities may be addressed: endemic populations should have a unique genetic signature relative to others in the world, while an introduced 
population should have a genetic signature indicative of the population from which it dispersed.

The A. tamarense isolated from Tasmania is unique among all other members of its species complex examined thus far, and stands alone as the sole representative of the "Tasmanian ribotype" (Fig. 1, Table 1). This organism is also non-toxic. If it is endemic to Tasmania, it may not be surprising that it went un-noticed until modern reports of toxigenic Alexandrium in Australian waters stimulated a more thorough search for these organisms. In that sense, the Tasmanian $\underline{A}$. tamarense may be an example of the elusive "hidden flora" found as a result of the scientific communities' increased awareness and search for these species.

LsrDNA sequences of Australian and Japanese $\underline{\text { A. catenella are }}$ amazingly similar (Fig. 1 and Table 1); the heterogeneity within and between these two populations is even less than that observed in the North American cluster (i.e., the "eastern," "western" and "alternate" subribotypes). The strong genetic affinity between Japanese and Australian A. catenella indicates that they are descended from the same population. However, a natural dispersal of Alexandrium from Asia to Australia (or vise versa) still cannot be ruled out: reductions of sea level and equatorial sea surface temperatures during Pleistocene glaciations may have provided a means by which this could have occurred (eg., over the last 1-2 Ma; Potts, 1983, Fleminger 1985). Fleminger (1985) has examined this region in detail with respect to various copepod species, and argues that some copepods 
dispersed from Asia to Australia and New Guinea. A prediction from Fleminger's work is that $\underline{A}$. catenella found in Japan or Australia should also appear genetically-similar to $\underline{\mathrm{A}}$. tamarense or $\underline{\mathrm{A}}$. $\underline{\text { catenella }}$ populations between southern Japan and Thailand. To date, only one A. tamarense from Thailand has been examined, and it is clearly divergent from the Australian and Japanese $\underline{\text { A. catenella (Fig. } 1 \text { and }}$ Table 1). Preliminarily, there is no positive indication that a recent Indo-Australian exchange of $\underline{A}$. catenella has occurred; characterization of other Alexandrium populations known to exist along the coast of China will help clarify this (cf. Chapt 6).

Though natural dispersal of $\underline{A}$. catenella to Australia cannot be dismissed, recent work by Hallegraeff and Bolch (1991 and 1992) conclusively demonstrates that viable resting cysts of toxigenic $\underline{A}$. $\underline{\text { tamarense }}$ and $\underline{\mathrm{A}}$. catenella have been discharged from the ballast tanks of cargo vessels into Australian ports. Some vessels are known

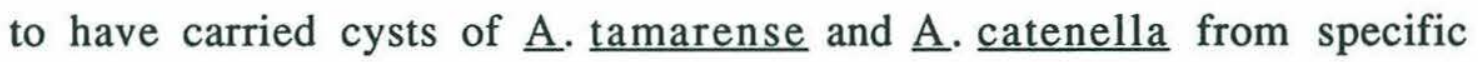
blooms in Japan and Korea (Table 1), thus providing their probable point of origin. The occurrence of North American (eastern) $\underline{A}$. tamarense in the ballast water of a ship that originated in Japan is of particular interest: this vessel has never been to North America, yet it contained $\underline{\mathrm{A}}$. tamarense that are identical to some $\underline{\mathrm{A}}$. tamarense/ fundyense isolated from eastern North America (Fig 1 and Table 1; cf. Appendix C.2). Thus, some North American strains of $\underline{\mathrm{A}}$. tamarense may have not only been introduced to Japan, but also transported from Japan to Australia. The occurrence of Temperate Asian (Japanese) $\underline{\text { A }}$. catenella in a ballast water samples is also 
significant, since they are essentially identical to those isolated in Australia in 1988.

The ballast water samples show that viable toxigenic Alexandrium cysts are dispersing as a direct result of man's activities, and serve to illustrate how a region can be "seeded" with genetically-distinct $\underline{\text { A. }} \underline{\text { tamarense }}$ and $\underline{\text { A. catenella from a variety of }}$ source populations. If the introduced $\underline{\mathrm{A}}$. $\underline{\text { tamarense }}$ and $\underline{\mathrm{A}}$. catenella cysts ultimately give rise to blooms of these organisms in Australia, then the various populations could appear heterogeneous, reflecting the morphological, biochemical and genetic signatures of the populations from which they have dispersed. On-going dispersal of toxic Alexandrium cysts to Australia may serve as a living example of what may have occurred in Japan, and could partially explain the origins of Japanese $\underline{A}$. tamarense and $\underline{A}$. catenella population heterogeneity.

\section{MATERIALS and METHODS}

Details of nucleic acid extraction, SsrDNA RFLP assay ("A/B restriction test), sequence analysis of LsrDNA, and cultures used in these investigations are found elsewhere (Chapts. 2 and 3). SsrDNAs from representatives of the North American, Western European, Temperate Asian and Tasmanian ribotypes (see Table 1 for the isolates chosen) were PCR-amplified as described previously (Chapt. 2 ), with the exception that the $3^{\prime}$ (reverse) primer was biotinylated. Purification of the coding strand of the SsrDNAs was achieved using 
streptavidin-coated magnetic beads (Dynal Dyna Bead $\mathrm{TM}$ ) following the recommendations of the manufacturer (Dynal; cf. Hultman et al., 1989; Uhlen, 1989). Primers complementary to Dictyostelium discoideum nucleotide sequences 892-906, and 962-976 (Sogin and Gunderson 1987) were used to sequence (United States Biochemical Sequenase V 2.0) a portion of the SsrDNAs (positions $\sim 636$ to $~ 1158$ ). Products of these sequencing reactions were resolved side-by-side as described previously (Chapter 3). Sequences from the Western European, Temperate Asian and Tasmanian representatives were compared to that from the eastern North American isolate in which the A and B SsrDNAs were originally characterized (GtCA29; Chapt.1). Two Western European representatives were chosen because one (Pgt 183) is non-toxic, while another (PE1V) may make trace amounts of toxin; the two were included to determine if there was any strict association between the $\mathrm{B}$ gene and isolates' ability to produce toxin. The LsrDNA sequence from the Thailand $\underline{A}$. tamarense has only been deduced recently, and has not yet been examined for "B-like genes."

\section{LITERATURE CITED}

Anderson, D.M. (1989). Toxic algal blooms and red tides: a global perspective. In : Okaichi,T., Anderson, D.M., and Nemoto,T. (eds.) Red tides: biology, environmental science and toxicology. Elsevier, New York, pp. 11 - 20. 
Anraku, M. (1984). Shellfish poisoning in Japanese waters. In: White, A.W., Anraku, M., Hooi, K.-K. (eds.) Toxic red tides and shellfish toxicity in southeast Asia. Southeast Asian Fisheries Development Center, Singapore, and the International Development Research Centre, Ottawa, Canada. pp. 105 - 109.

Ayala, F. J., Kiger, J. A. Jr. (1980). Modern Genetics. Benjamin/ Cummings, California. 844 pp.

Balech, E. (1985). The genus Alexandrium or Gonyaulax of the tamarensis group. In : Anderson, D.M., White, A.W., Baden, D.G. (eds.) Toxic Dinoflagellates. Elsevier, New York, pp. 33 - 38.

Balech, E., Tangen, K. (1985). Morphology and taxonomy of toxic species in the tarmarensis group (Dinophyceae): Alexandrium excavatum (Braarud) comb. nov. and Alexandrium ostenfeldii (Paulsen) comb. nov. Sarsia 70: 333-343.

Berrggren, W. A., Hollister, C. D. (1974). Paleogeography, paleobiogeography and the history of circulation in the Atlantic Ocean. In: Studies in paleo-oceanography. Hay, W.W. (ed.). Society of Economic Paleontologists and Minerologists special publication No. 20. pp.126-185.

Brooks, D. R., McLennan, D. A. (1991). Phylogeny, ecology and behavior. A research program in comparative biology. University of Chicago Press, Chicago and London. 434 pp.

Cembella, A.D., Taylor, F.J.R., Therriault, J.-C. (1988). Cladistic analysis of electrophoretic variants within the toxic dinoflagellate genus Protogonyaulax. Botanica Marina 31: 3951 .

Cembella, A.D., Sullivan, J.J., Boyer, G.L., Taylor, F.J.R., Andersen, R.J. (1987). Variation in paralytic shellfish toxin composition within the Protogonyaulax tamarensis/catenella species complex: red tide dinoflagellates. Biochem.Syst.and Ecol. 15: $171-186$.

Cembella, A.D., Taylor, F.J.R. (1986). Electrophoretic variability within the Protogonyaulax tamarensis/catenella species complex: pyridine linked dehydrogenases. Biochem.Syst.and Ecol. 14: 311-323. 
Clark, D. L., Acrtic Ocean ice cover; geologic history and climatic significance. In: Grantz, A., Johnson, L., Sweeny, J.F. (eds.). The Geology of North America. Vol. L. The Arctic Ocean Region. pp. $53-62$.

Culotta, E. (1992). Red menace in the world's oceans. Science. 257: 1476-1477.

Fleminger, A. (1985). The pleistocene equatorial barrier between the Indian and Pacific Oceans and a likely cause for Wallace's line. In: Pierot-Bults, A.C., van der Spoel, S., Zahuranec, B.J., johnson, R.K. (eds.). Pelagic Biogeography. Proc. of an international conf. The Netherlands. Unesco technical papers in maine science 49. pp. 84-97.

Fukuyo, Y. (1985). Morphology of Protogonyaulax tamarensis (Lebour) Taylor and Protogonyaulax catenella (Whedon and Kofoid) Taylor from Japanese coatal waters. Bull. Marine Sci. 37: 529-537.

Gobel, U.B., Geiser, A., Stanbridge, E.J. (1987). Oligonucleotide probes complementary to variable regions of ribosomal RNA discriminate between Mycoplasma species. J.Gen.Microbiol. 133:1969-1974.

Guadet, J., Julien, J., Lafay, J. F., Brygoo, Y. (1989). Phylogeney of some Fusarium species, as determined by large-subunit rRNA sequence comparison. Mol.Biol.Evol. 6:227-242.

Hallegraeff, G., Bolch, C.J. (1991). Transport of toxic dinoflagellate cysts via ship's ballast water. Mar.Poll.Bull. 22: 27-30.

Hallegraeff, G., Bolch, C.J., Blackburn, S.I., Oshima, Y. (1991). Species of the toxigenic dinoflagellate genus Alexandrium in southeastern Australian waters. Botanica Marina 34: 575-587.

Hallegraeff, G., and Bolch, C.J. (1992). Transport of toxic dinoflagellate cysts via ship's ballast water: implications for plankton biogeography and aquaculture. J. Plankton Res. 14: 1067-1084. 
Hallegraeff, G. M., Steffensen, D.A., Wetherbee, R. (1988). Three estuarine Australian dinoflagellates that can produce paralytic shellfish toxins. J. Plankton Res. 10: 533-541.

Hashimoto. (1976). Nippon Suisan Gakkaishi 42: 671-676.

Hultman, T., Stahl, S., Hornes, E., Uhlen, M. (1989). Direct solid phase sequencing of genomic and plasmid DNA using magnetic beads as solid support. Nuc.Acids Res. 17:4937-4946.

Kawai, H. Hydrography of the Kuroshio extension. In: Stommel, H., Yoshida, K. (eds.). Kuroshio. Its physical aspects. Univ. of Tokyo press. pp. 235-352.

Keafer, B. A., Buesseler, K. O., and Anderson, D. A. (1992). Burial of living dinoflagellate cysts in estuarine and nearshore sediments. Marine Micropaleontology. (in press).

Kvitek, R. G. (1992). Paralytic shellfish toxins as a chemical defense in the butter calm (Saxidomus gigantus). In: Smayda, T.J., Shimizu, Y. (eds.) Fifith international conference on toxic marine phytoplankton. Elsevier, New York (in press).

Le Messurier, D.J. (1935). A survey of mussels on a portion of the Australian coast. Meical J. Australia. 1:490-492.

Lenaers, G., Scholin, C. A., Bhaud, Y., Saint-Hilaire, D., Herzog, M. (1991). A molecular phylogeny of dinoflagellate protists (Pyrrhophyta) inferred from the sequence of the 24S rRNA divergent domains D1 and D8. J. Mol. Evolu. 32:53-63.

Lenaers, G., Maroteaux, L., Michot, B., Herzog, M. (1989). Dinoflagellates in evolution. A molecular phylogenetic analysis of large subunit ribosomal RNA. J. Mol. Evol. 29:40-51.

Lenaers, G., Nielsen, H., Engberg, J., Herzog, M. (1988). The secondary structure of large-subunit rRNA divergent domains, a marker for protist evolution. BioSys. 21: 215 - 222.

Luyendyk, B. P., Forsyth, D., Phillips, J. D. (1972). Experimental approach to the paleocirculation of the oceanic surface waters. Geological Soc. of America Bull. 83: 2649-2664. 
Lynch, J. D. (1989). The gauge of speciation: on the frequencies of modes of speciations. In: Otte, D., Endler, J. A. (eds.). Speciation and its consequences. Sinauer Associates, Inc., Sunderland, Massachusetts. pp. 527-553

Marincovich, L. Jr., Brouwers, E. M., Hopkins, D. M., McKenna, M. C. (1990). Late Mesozoic and Cenozoic paleogeographic and paleoclimatic history of the Arctic Ocean Basin, based on shallow-water marine faunas and terrestrial vertebartes. In: Grantz, A., Johnson, L., Sweeny, J.F. (eds.). The Geology of North America. Vol. L. The Arctic Ocean Region. pp. 403-426.

McCutchan, T. F., de la Cruz, V.F., Lal, A. A., Gunderson, J. H., Elwood, H.J., Sogin, M.L. (1988). Primary sequences of two small subunit ribosomal RNA genes from Plasmodium falciparum. Molec. Biochem. Parasitol. 28:63-68.

Mitchot, B., Hassouna, N., Bachellerie, J.P. (1984). Secondary structure of mouse 28S rRNA and general model for the folding of the large RNA in eukaryotes. Nuc.Acids Res. 12::4259-4279.

Mitchot, B., Bachellerie, J.P. (1987). Comparisons of large subunit rRNAs reveal some eukaryote-specific elements of secondary structure. Biochimie 69:11-23.

Murano (1975). Bull. Plankton Soc. Japan 22:33-38.

Pikard, G.L. (1979). Descriptive physical oceanography. Third ed. Pergamon press. $233 \mathrm{pp}$.

Potts, D. L. (1983). Evolutionary disequilibrium among Indo-Pacific Corals. Bull. Mar. Sci. 33: 619-632.

Prakash, A., Medcof, J. C., Tennant, A.D. (1971). Paralytic shellfish poisoning in eastern Canada. Fisheries Research Board of Canada. Bulletin 177. 87 pp.

Qualye, D. B. (1969). Paralytic shellfish poisoning in British Columbia. Fisheries Research Board of Canada. Bulletin 168. 68 pp.

Raue', H.A., J. Klootwijk and W. Musters. 1988. Evolutionary conservation of structure and function of high molecular weight ribosomal RNA. Prog. Biophys.molec. Biol. 51: 77 - 129. 
Saiki, R.K., Gelfand, D.H., Stoffel, S., Scharf, S.J., Higuchi, R., Horn, G.T., Mullis, K.B., Erlich, H.A. (1988). Primer-directed enzymatic amplification of DNA with a thermostable DNA polymerase. Science. 239:487-491.

Sako, Y. (1992). Molecular definition and detection of toxic-harmful phytoplankton species. In: Smayda, T.J., Shimizu, Y. (eds.) Fifith international conference on toxic marine phytoplankton. Elsevier, New York (in press).

Sako, Y., Adachi, M., Ishida, Y. (1992). Preparation and characterization of monoclonal antibodies to Alexandrium species. In: Smayda, T.J., Shimizu, Y. (eds.) Fifith international conference on toxic marine phytoplankton. Elsevier, New York (in press).

Sako, Y., Kim, C.H., Ninomiya, H., Adachi, M., Ishida, Y. (1990). Isozyme and cross analysis of mating populations in the Alexandrium catenella/tamarense species complex. In: Graneli, E., Sundstrom, B., Edler, L., Anderson, D.M. (eds) Toxic Marine Phytoplankton. Elsevier, New York, pp. 320-323.

Smayda, T.J. (1990). Novel and nuisance phytoplankton blooms in the sea: Evidence for a global epidemic. In: Graneli, E., Sundstrom, B., Edler, L., Anderson, D.M. (eds) Toxic Marine Phytoplankton. Elsevier, New York, pp. 29-40.

Sogin, M.L. \& Gunderson, J.H. 1987. Structural diversity of eukaryotic small subunit ribosomal RNAs: evolutionary implications. Endocytobiology III. Ann. N.Y. Acad. Sci. 503:12539.

Steidinger, K.A., Baden, D. G. (1984). Toxic marine dinoflagellates. In: Spector, D. L. (ed.). Dinoflagellates. Academic Press. pp. 201261.

Steidinger, K.A., Moestrup, Ø. (1990). The taxonomy of Gonyaulax, Pyrodinium, Alexandrium, Gessnerium, Protogonyaulax and Goniodoma. In: Graneli, E., Sundstrom, B., Edler, L., Anderson, D.M. (eds) Toxic Marine Phytoplankton. Elsevier, New York, pp. 522-523. 
Taylor, F. J. R. (1987). General and marine ecosystems. In: Taylor, F. J. R (ed.). The Bilogy of dinoflagellates. Blackwell Scientific, Oxford, pp. 399-502.

Taylor, F. J. R. (1985). The taxonomy and relationships of red tide dinoflagellates. In Anderson, D.M., White, A.W., and Baden, D.G. (eds.) Toxic Dinoflagellates. Elsevier, New York, pp. 11-26.

Taylor, F. J. R. (1984). Toxic dinoflagellates: taxonomic and biogeographic aspects with emphasis on Protogonyaulax. In: Ragelis, E.P. (ed.) Seafood Toxins. Amer. Chem. Soc. Symp. Series No. 262, Washington, D.C. pp. 77-97.

Taylor, F.J.R. (1980). On dinoflagellate evolution. Biosystems 13: 65108.

Thiede, J., Clark, D. L., Herman, Y. (1990). Late Mesozoic and Cenozoic paleoceanography of the northern polar oceans. In: Grantz, A., Johnson, L., Sweeny, J.F. (eds.). The Geology of North America. Vol. L. The Arctic Ocean Region. pp. 427-458.

Uhlen, M. 1989. Magnetic separation of DNA. Nature 340:733-734. 


\section{Chapter 5}

Summary and Conclusions 
Sequence analysis of small subunit (Ss) and large subunit (Ls) ribosomal RNA genes (rDNA) was undertaken in an effort to clarify relationships among a variety of Alexandrium species, and their globally-distributed populations. The goal of this study was to address two basic questions:

1) What level of taxonomic organization are these sequences capable of resolving - strain, population, species, genera?

2) Can this information be applied to ecologically-relevant questions?

At the start of this investigation, little was known of intra- and interspecific rRNA/DNA sequence variation among dinoflagellates. The first broad-scoped investigation aimed at addressing this question was conducted by Lenears et al. (1989), ${ }^{1}$ using the D1 and D8 hypervariable regions of the LsrRNA. Their report demonstrated that LsrRNA sequences resolved fundamental genetic differences between genera and species of dinoflagellates. In particular, these investigators showed a toxic, western North American $\underline{A}$. catenella (BGt 1) to be closely-related to, but distinct from, a non-toxic, Western European A. tamarense (Pgt 183); this was the first indication of rDNA sequence divergence among two representatives of the $\underline{A}$. tamarense/catenella/fundyense "species complex." At the

${ }^{1}$ Lenaers, G., Scholin, C. A.,Bhaud, Y., Saint-Hilaire, D., Herzog, M. (1991). A molecular phylogeny of dinoflagellate protists (Pyrrhophyta) inferred from the sequence of the 24S rRNA divergent domains D1 and D8. J. Mol. Evolu. 32:53-63. 
same time, $\underline{A}$. andersoni (TC02) was shown to be clearly divergent

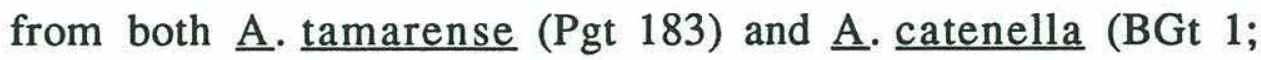
unpublished observation). Thus, the indication was that hypervariable domains within the LsrRNA molecule would be useful for delineating divergent Alexandrium species, and possibly even $\underline{\mathrm{A}}$. tamarense and $\underline{A}$. catenella.

At the same time Lenears and co-workers were completing their work, evolutionarily-variable regions within the SsrRNA molecule were already well-characterized. Here again, few dinoflagellate SsrRNA sequences had been deduced, and thus the variation or potential variation that might exist in these molecules for dinoflagellate genera and species was completely unknown. However, the extensive data base of SsrRNA sequences seemed a valuable resource for interpreting potential Alexandrium inter- or intra-specific variation in the context of a broader view of rRNA evolution. Therefore, this thesis was to focus on both the wellcharacterized SsrDNA molecule, and less well-characterized but promising portions of the LsrDNA molecule.

Chapter 1 documents the first attempt at determining the complete SsrDNA sequence for a toxic, eastern North American $\underline{A}$. fundyense (GtCA29). Surprisingly, this isolate was found to harbor two distinct SsrRNA genes, termed the "A gene" and "B gene." The B gene was determined to be pseudogene since portions of its sequence deviate from evolutionarily-conserved motifs, and because it is not represented by stable transcripts. The $\mathrm{B}$ gene holds promise as a 
population-specific marker: as a pseudogene, it could be subject to accelerated rates of nucleotide substitutions; furthermore, the $A$ and B sequences are $\sim 97.8 \%$ identical, indicating a recent divergence. However, the labor involved in identifying and documenting these two sequences using cloning and sequencing protocols made the prospects of examining a large number of cultures for the same genes difficult to justify. In order to expedite the screening procedure a restriction fragment length polymorphism (RFLP) assay, termed the "A/B gene restriction test," was developed (Chapt. 2).

SsrRNA from toxic, western North American $\underline{\text { A.tamarense/ }}$ catenella (PW06 and BGt 1), toxic, eastern North American $\underline{A}$. fundyense (CA29 and AFNFA4) and a non-toxic Western European $\underline{\text { A. }}$ tamarense (Pgt 183) were partially sequenced during efforts to detect B gene expression. Approximately 450 bases of SsrRNA spanning two highly variable domains within this molecule (V3 and V4) ${ }^{2}$ from each of the isolates were compared. All North American $\underline{A}$. tamarense/catenella/fundyense appeared identical; relative to that group, the Western European $\underline{A}$. tamarense showed four scorable differences. In contrast, preliminary LsrRNA sequence analysis of $\underline{A}$. fundyense (CA29), $\underline{\text { A }}$ catenella (BGt1) and $\underline{\text { A.tamarense }}$ (Pgt183) indicated more extensive sequence divergence. Therefore, plans for extensive sequencing of SrDNA variable regions were abandoned. Instead, isolates' SsrDNA were compared using the A/B restriction

2 cf. Sogin, M.L., Gunderson, J.H. (1987). Structural diversity of eukaryotic small subunit ribosomal RNAs: evolutionary implications. Endocytobiology III. Ann. N.Y. Acad. Sci. 503:125-39. 
assay (Chapt. 2), and detailed sequence comparisons relied primarily on a fragment of the LsrDNA (Chapt. 3).

Chapter 2 summarizes results of the SsrDNA RFLP tests. Early in this work, the B gene was found in all toxic, North American $\underline{A}$. tamarense/catenella/fundyense, but was absent in all non-toxic Western European $\underline{\text { A.tamarense. }}$. The apparent association between the $\mathrm{B}$ gene and toxic isolates of Alexandrium prompted a search for B genes in globally-distributed representatives of $\underline{\text { A.tamarense/ }}$ catenella, as well as in toxic $\underline{A}$. minutum. Results of these screens clearly demonstrated that the B gene was not essential for toxin production, neither for $\underline{\mathrm{A}}$. tamarense/catenella/fundyense, nor $\underline{\mathrm{A}}$. minutum. However, the RFLP assay did reveal five distinct groups of cultures. Three of these ("Groups I-III") subdivide the $\underline{\mathrm{A}}$. tamarense/catenella/fundyense complex, but do not correlate with morphospecies designations. The fourth group ("Group IV") consists of $\underline{A}$. affine, and the fifth group ("Group V") is represented by $\underline{A}$. minutum, $\underline{\mathrm{A}}$. $\underline{\text { lusitanicum}}$, and $\underline{\mathrm{A}}$. $\underline{\text { andersoni. Restriction patterns of }}$ SsrDNA from one isolate of $\underline{\text { A. tamarense }}$ (CU-1) appeared identical to those of $\underline{\mathrm{A}}$. affine. It was later determined that CU-1 was in fact an

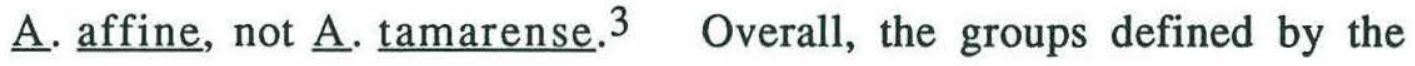
SsrDNA RFLP assay agree with those defined by morphotaxonomic criteria: as a whole, the $\underline{\mathrm{A}}$. tamarense/catenella/fundyense complex is distinct from $\underline{\mathrm{A}}$. $\underline{\text { affine }}, \underline{\mathrm{A}} . \underline{\text { minutum}}, \underline{\mathrm{A}}$. $\underline{\text { lusitanicum }}$ and $\underline{\mathrm{A}}$. andersoni: the further delineation of $\underline{A}$. affine and $\underline{A}$. minutum, $\underline{A}$.

3 CU-1's morphology was re-examined by Dr. Y. Fukuyo, one of the taxonomists who originally described $\underline{\mathrm{A}}$. affine. 


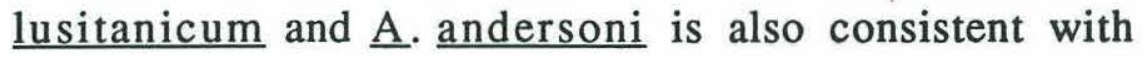
morphotaxonomic designations.

The $A / B$ restriction tests provided the first indication that $\underline{A}$.

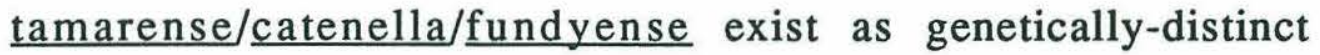
populations, not three genetically-distinct morphospecies. Isolates of

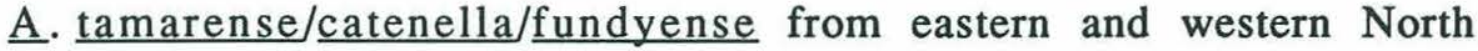
America belong exclusively to Groups I and II, respectively. Both groups include representatives of all three morphospecies that harbor the B gene. ${ }^{4}$ Alexandrium tamarense/catenella isolated from Western Europe, Australia and Thailand, on the other hand, belong exclusively to Group III and do not harbor the B gene. Isolates of $\underline{A}$. tamarense from scattered locations in Japan were classified as members of Groups I and II; all Japanese $\underline{\text { A. catenella belong to }}$ Group III. Ballast water isolates that originated from specific blooms in Japan reinforced the conclusion that Japanese populations of $\underline{A}$.

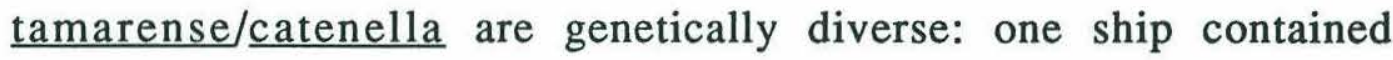
Group I $\underline{A}$. tamarense, while a second carried a Group III $\underline{A}$. catenella. Thus, the assemblage of $\underline{\mathrm{A}}$. tamarense/catenella in Japan is "exceptional" relative to other globally-distributed isolates examined thus far.

A dispersal of Group I and II $\underline{\text { A. }}$ tamarense from North America to Japan seemed probable for two reasons. First, Groups I and II

\footnotetext{
4 the distinction between Group I and II is based on the observation that some of Group I's SsrRNA genes have insertions and/or are rearranged (Appendix B. ); Group II's SsrRNA genes, on the other hand, show no such rearrangements.
} 
have uniform biogeographic distributions in North America. In contrast, these organisms occur in scattered locations in Japan and are intermixed with Group III $\underline{\text { A. }}$ catenella. Second, PSP toxicity appeared in Japan in 1948, but dates back hundreds of years in North America.

The occurrence of Group I $\underline{A}$. tamarense in a ship's ballast tanks was also peculiar: this vessel was on a defined run between Japan and Australia and apparently had never been to North America, yet it contained A. tamarense "identical" to those found in eastern North America. Furthermore, these particular ballast water isolates were thought to originate from a specific bloom in Japan. This suggested a

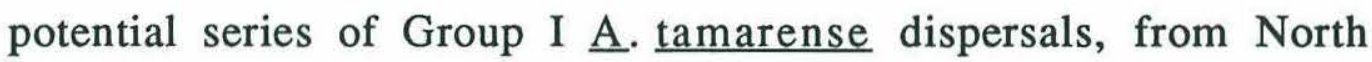
America to Japan, and from Japan to Australia.

The existence of genetically-distinct populations of $\underline{\mathrm{A}}$. tamarense/catenella/fundyense began to shed light on the confusing associations between cells' "morphotypes" and "genotypes" (i.e., subcellular characteristics). Alexandrium tamarense and $\underline{\text { A. }} \underline{\text { catenella }}$ from Japan have been heralded as a paradigm of "morphospecies": species defined by morphological features are positively correlated with groups defined by subcellular characterizations. In contrast, morphological, biochemical and genetic analyses of $\underline{\mathrm{A}}$. tamarense/ catenella/fundyense from North America do not reveal such positive correlations, and offer no support for the morphospecies concept. Results of the $A / B$ gene restriction tests suggest that the latter observation is more akin to what is expected. The genetically- 
diverse $\underline{\text { A. }}$ tamarense/catenella found in Japan hinted at a possible fortuitous correlation of "morphotypes" and "genotypes."

In Chapter 3, questions of taxonomy and biogeography were addressed in greater detail: a subset of isolates screened in the $A / B$ restriction tests were further compared by sequencing a fragment of their LsrDNA. Parsimony analyses revealed eight major classes of sequences, termed "ribotypes." Five ribotypes subdivide members of the $\underline{A}$. tamarense/catenella/fundyense complex, and were named with reference to the geographic origin of the isolates: "North American," "Western European," "Temperate Asian," "Tasmanian" and "Tropical Asian." The three remaining ribotypes were associated with cultures that clearly differ morphologically from the $\underline{A}$. tamarense/catenella/fundyense group; these three distinct sequences are typified by: 1) $\underline{A}$. $\underline{\text { affine; }}$ 2) $\underline{\mathrm{A}}$. minutum and $\underline{\mathrm{A}}$. lusitanicum; and, 3) $\underline{A}$. andersoni. The latter three ribotypes were referred to as "affine," "minutum" (= $\underline{\mathrm{A}}$. $\underline{\text { minutum/lusitanicum) }}$ ) and "andersoni," respectively. Alexandrium minutum and $\underline{\text { A. }} \underline{\text { lusitanicum }}$ are indistinguishable on the basis of their LsrDNA sequence; $\underline{\mathrm{A}}$. minutum/lusitanicum/andersoni may be members of another Alexandrium species complex, analogous to the $\underline{A}$. tamarense/ catenella/fundyense group. An organisms' ability to produce toxin appears to be correlated with its LsrDNA phylogenetic lineage: the North American, Temperate Asian, Tropical Asian, and "minutum" termini are exclusively "toxic," whereas Western European, Tasmanian, "affine" and "andersoni" termini are exclusively "non- 
toxic." Analysis of additional isolates is required to address this potential correlation.

The ribotypes ascribed by the LsrDNA sequences are in complete agreement with, and offer a finer-scale resolution of, groups defined by the SsrDNA RFLP analysis. Those organisms found to harbor the B gene are all classified as members of the North American ribotype. Furthermore, there appears to be a gradient of sequence specificity, from regional to globally-distributed populations of A. tamarense/catenella/ $\underline{\text { fundyense, }}$, to distinct species outside of this cluster. Japanese $\underline{A}$. tamarense/catenella are an exception to this trend: these isolates were found to display sequences that encompass North American, Western European and Temperate Asian signatures.

Overall, the LsrDNA phylogeny of A. tamarense/catenella/ fundyense resolves geographic populations, not morphospecies. This is consistent with the conclusions reached in Chapter 2. Though morphospecies designations are a convenient and important way of describing A. tamarense/catenella/ $\underline{\text { fundyense, }}$, they do not convey a sense of these organisms underlying genetic diversity and population structure. This conclusion has been reached independently by other investigators using a variety of subcellular characterizations. However, prior to this investigation comparisons have focussed primarily on cultures collected from a single, regional population: Japan, western North America or eastern North America. Each of these regions appears to encompass a unique assemblage of these 
organisms. Depending on which cultures are examined, and where they come from, one can reach different conclusions concerning morphotype and its relation to isolates' biochemical or genetic affinities. Hence, the "validity" of the morphospecies concept depends on the isolates compared. In the case of Japanese $\underline{A}$.

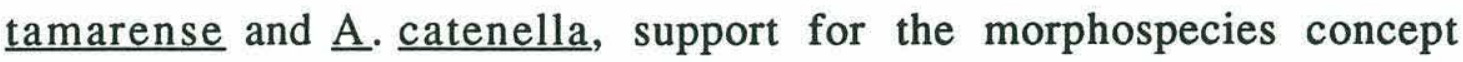
appears stem from the fortuitous co-occurrence of different strains of these species (eg., North American $\underline{A}$. tamarense and Temperate Asian $\underline{\text { A. catenella }})$.

An evolutionary perspective for the A. tamarense/catenella/ fundyense species complex was developed in Chapter 4 in an effort to explain the confusing associations of "morphotype," "ribotype," and "geographic population." It is suggested that these organisms arose from a common ancestor that included, or gave rise to, all three morphotypes. Over millions of years of evolution, populations containing one or more of the morphotypes are presumed to have become geographically-isolated, and then to have undergone independent genetic divergence (vicariant speciation); however, ancestral (or derived) morphodiversity was maintained during this process. Consequently, endemic populations of co-occurring morphospecies appear genetically-similar, despite the fact that they are morphologically-distinct.

SsrDNA from Western European, Temperate Asian and Tasmanian representatives were further characterized in Chapter 4 by direct sequencing of PCR products, to determine if sequences 
similar to the B gene ("B-like genes") were missed in the RFLP assay. Results indicate that the B gene is exclusively associated with the North American ribotype. The B gene and contiguous LsrDNA sequences are therefore indicative of a unique evolutionary lineage (geographic population) of the $\underline{A}$. tamarense/catenella/fundyense complex, a group that is likely endemic to North America. The occurrence of B gene-containing A. tamarense in Japan appears to be an indication of dispersal. However, determining the timing of dispersal events is problematic since rDNA sequences, even the hypervariable LsrDNA D2 domain, evolve on a scale of millions of years; populations that have been separated for thousands, or a million years will appear genetically-similar with respect to their rDNA. Thus, using rDNA sequences as indicators of $\underline{A}$. tamarense/ catenella/fundyense population heterogeneity and dispersal necessitate that it be done with an eye to the geologic past lest the wrong conclusions regarding the timing and mode of dispersal be reached. Finally, the ballast water samples show that viable cysts of toxigenic Alexandrium are being introduced to Australia from genetically distinct source populations. In some respects, this may serve as a living example of what occurred in Japan some years ago, and what may be occurring in other regions of the world.

In conclusion, SsrDNA RFLP groups and LsrDNA ribotypes are valuable species- and population-specific markers. Hopefully this information will be of use in reaching an internationally-acceptable definition of Alexandrium "species." Finally, oligonucleotide probes targeted at rRNA/DNA have the potential to discriminate at various 
levels of Alexandrium taxonomic organization, and may be useful in the rapid and specific analyses of cultured or field samples. 


\section{Chapter 6}

Suggestions for Future Study 
The analysis of Alexandrium rDNA sequences has provided a phylogenetic perspective from which to view a variety of fundamental biological questions. In this context, future areas of research should consider the following:
A. Clarification of Morphotaxonomy
B. Evolution, Population Biology and Dispersal
C. Sexual Compatibility and Meiotic Partitioning of Genes
D. Molecular Detection of Strains, Species and Genera
E. Genetic Basis of Toxin Production

To many, these topics seem obvious targets for future study, and in some cases are underway in laboratories throughout the world. This serves to illustrate an important point: even the most basic questions of Alexandrium biology remain unanswered, despite many years of research. The intent of the present discussion is to frame these questions with respect to molecular phylogenetic analyses.

\section{A. Clarification of Morphotaxonomy}

The primary difficulty in interpreting relationships between closely-related Alexandrium species, such as $\underline{\mathrm{A}}$. tamarense/ catenella/fundyense, and their rDNA sequences rests with morphotaxonomy of the isolates. Inconsistencies in species designations could arise if isolates are classified by different 
taxonomists. In fact, this criticism was raised by Dr. Fukuyo at the Fifth International Conference on Toxic Marine Phytoplankton. His question concerned the potential artifacts that could be introduced by comparing "Fukuyo species" to "Balech species," for example. This criticism has been addressed in both Chapters 2 and 3. Future studies addressing the relationships between morphotype and "genotype" for closely-related species like $\underline{\text { A. tamarense/catenella/ }}$ fundyense would be well-advised to have at least two authorities classify the isolates in question. In so doing, it will be possible to directly compare different taxonomists designations, and determine: 1) what, if any, inconsistencies exist; and, 2) how that might affect conclusions reached in this thesis.

\section{B. Evolution, Population Biology and Dispersal}

Ribosomal DNA sequences are useful tools for studying the evolution, population biology and dispersal of Alexandrium species. The basis for this approach is broadly outlined in Chapter 4. With this as background, it is now possible to address more specific questions. Regarding the $\underline{A}$. tamarense/ $\underline{\text { catenella/fundyense complex }}$ in particular, consideration should be given to the following:

1) Do B gene "subgroups" exist? If so, what is their biogeographic distribution?

2) What is the basis of the apparent genetic heterogeneity of western North American $\underline{\text { A. tamarense/catenella? }}$ 
3) Is there evidence to support a natural dispersal of $\underline{A}$. tamarense to Japan?

4) Is there evidence to support a natural dispersal of $\underline{A}$. catenella to Australia?

All of these questions point to a need for additional characterization of globally-distributed representatives of A. tamarense/catenella/ fundyense

With regards to Question 1:

The B gene is a pseudogene and thus potentially subject to accelerated rates of nucleotide substitution. If it is undergoing "rapid" evolution, then it should be very sensitive to populations' isolation - probably more so than the LsrDNA D2 domain. Consequently, "B gene subgroups" may exist, and could be useful biogeographic markers. A search for B gene subgroups can be carried out by either more extensive RFLP analyses (cf. Appendix B), or by using the magnetic bead sequencing technique (cf. Chapter 4).

With regards to Question 2:

There are several possible "sources" for the reported genetic diversity of western North American $\underline{\text { A.tamarense/catenella }}$ populations, including:

a) diversification of biochemical signatures among sympatric populations; 
b) co-occurrence of allopatric Alexandrium populations resulting from paleo-oceanographic events (e.g., opening of the Bering Straight and exchange of "Arctic" and "East Pacific" fauna); or,

c) recent, human-assisted introduction of an allopatric population(s).

Neither of these scenarios is mutually exclusive; however, it should be possible to evaluate each possibility by examining the sequences of Ss and LsrDNA from additional western North American $\underline{A}$. $\underline{\text { tamarense/catenella }}$ isolates.

In the first case (a), all isolates should carry the B gene and exhibit minimal LsrDNA sequence divergence since they are descended from the same geographic population. Furthermore, the LsrDNA signature should place them well within the North American phylogenetic cluster. If this is so, then biochemical (= allelic) variation among $\underline{\text { A.tamarense/ }} \underline{\text { catenella }}$ must proceed at much more rapid pace than sequence divergence of even the most hypervariable rDNA domains.

In the second case (b), the LsrDNA sequences from some isolates should be very similar to those of the western North American $\underline{A}$. tamarense/catenella previously described (e.g., PW06); other isolates, however, will be "genetically-distinct." The "distinct" group should lack the the B gene, and its LsrDNA signature should define a heretofore undescribed evolutionary lineage (i.e., ribotype) of the $\underline{A}$. tamarense/catenella/fundyense complex. 
In the third case (c), the LsrDNA sequences from some isolates should be very similar to those of the western North American $\underline{A}$. tamarense/catenella previously described (e.g., PW06). As in (b), another, "genetically-distinct " group should be present. In contrast to (b), the "distinct" group will carry an LsrDNA signature indicative of the population from which the introduced organisms dispersed. With regards to this possibility, note that oysters from Japan were introduced to British Columbia, and subsequently exported from British Columbia and re-introduced to Japan (Taylor, pers. comm.). Thus, at one time, there was an exchange of shellfish stocks between British Columbia and Japan, and such exchanges are known vectors for dispersing algal species. In addition, raw wood products are routinely exported from western North America to Asian countries (notably Japan), and cargo vessels designed for such freight are known to have played a role in the dispersal of viable $\underline{A}$. tamarense

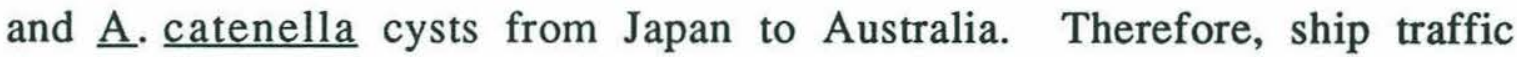
between Asian countries (or elsewhere) and western North America could have served as a vector for the introduction of $\underline{A}$. tamarense and $\underline{\mathrm{A}}$. catenella to the northwest. If an introduction has occurred, it seems likely that the introduced population will belong to the Temperate Asian cluster.

Examining additional western North American $\underline{\text { A. tamarense/ }}$ catenella is guaranteed to reveal an interesting story. It will be relevant to issues of: 1) "morphotype" vs. "genotype;" 2) biogeography; 3) evolution; and, 4) dispersal. 
With regards to Question 3:

Convincing proof of a natural dispersal of $\underline{A}$. tamarense to Japan is lacking. In large part this is because so few isolates have been analyzed (both from Japan and western North America), and because there is no fossil data. However, if dispersal occurred over a million years ago, for example, then there may have been sufficient time for rDNA to record the divergence. Note that eastern and western North American populations are distinguishable from each other, reflecting perhaps three million years of isolation. Therefore, "North American A. tamarense" potentially dispersed to Japan in the same time frame may be distinct from the "eastern" and "western" subribotypes. In some respects there is support for this possibility. Alexandrium tamarense from Ofunato Bay harbor the B gene and North American LsrDNA signatures, but differ slightly from both "eastern" and "western" subgroups. In fact, the fine-scale differences exhibited by the Ofunato Bay $\underline{\text { A. }}$ tamarense have been used to define the "North American (alternate)" ribotype (cf. Appendix C). To date too few isolates have been examined to be confident that this ribotype is unique to Japan. However, should additional analyses indicate that this is the case, then it is consistent with the notion that dispersal took place in the recent geologic past. Mapping the biogeographic distribution of B-gene subgroups could also be of help in this regard. In addition, determining if $\underline{A}$. tamarense occur along the Kuril Islands (north of Hokkaido) and the northeastern coast of Asia is also relevant given the projected path of dispersal (see Chapt. 4). If $\underline{A}$.tamarense exists in these regions because of a dispersal 
from North America, then they should harbor the B gene. Here again, any indications of fine-scale LsrDNA heterogeneity, or of B gene subgroups will be important. Finally, it would be instructive to examine the genetic similarities of other species that share a present day biogeographic distribution similar to the Alexandrium "North American" group, but that also have an adequate fossil record (gastropods? bivalves? macroalgae?): Do other species' fossil history and present-day genetic similarities support an Oyashio-mediated dispersal of organisms from the Bering Straight to the northern end of Japan? If so, what is the timing of such events? Is it consistent with the opening of the Bering Straight?

With regards to Question 4:

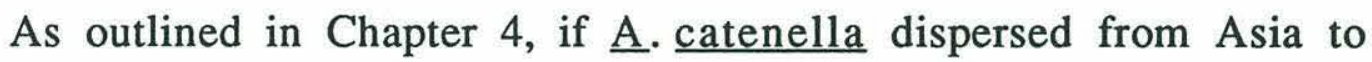
Australia by natural means within the last 1-2 million years, then $\underline{A}$. catenella found in Japan or Australia should also appear geneticallysimilar to populations of $\underline{A}$. $\underline{\text { tamarense }}$ or $\underline{A}$. catenella from southern Japan to Thailand. As a first step in testing this prediction, $\underline{A}$. tamarense from the coast of China (currently in culture) should be analyzed. The absence of genetically-similar $\underline{A}$. tamarense/catenella between Japan and Australia does not preclude the possibility of a natural introduction of $\underline{A}$. catenella to Australia; however, it severely weakens the possibility. 


\section{Sexual Compatibility and Meiotic Partitioning of Genes}

A number of laboratories throughout the world are beginning to apply classical genetic approaches in the study of Alexandrium biology. Experiments addressing sexual compatibilities of morphospecies and the meiotic partitioning of (1) morphotypic determinants, (2) mating type and (3) toxin compositions characteristics are already well underway. The relationships of $\underline{A}$. tamarense/catenella/fundyense described in this thesis are a useful reference for these experiments. In addition, the B gene and LsrDNA ribotypes could be used as genetic markers in multifactor factor crosses.

In Chapter 4, it was concluded that the $\underline{\mathrm{A}}$ tamarense/catenella/ fundyense complex arose from a common ancestor that included all three morphotypes. The B gene's occurrence in all three morphospecies was used to support this argument. Taken one step further, this can be explained by sexual-compatibility of $\underline{A}$. tamarense/catenella/fundyense; hence the B gene's presence in each given several million of years of interbreeding. Since these organisms are heterothallic, there should be strong selective pressure maintaining sexual compatibilities. This is expected because the evolution of a sexually-incompatible group requires at least two simultaneous mutations (one in the "+" parent and one in the "-" parent) that both restricts their ability to mate with certain members of the species complex, and allows them to be compatible only within 
the "new group."1 Retention of sexual compatibility should therefore be favored, but evolution of sexually-incompatible groups could certainly occur. Thus, the prediction is that closely-related $\underline{\mathrm{A}}$. tamarense/catenella/fundyense, such as those with similar LsrDNA sequences, should all be capable of forming cysts and producing viable progeny. If this is so, then it is possible that more distantlyrelated groups (eg. North American and Tasmanian) will be compatible as well. A difficulty in the mating experiments will performing enough crosses so that the results can be interpreted in a statistically-meaningful fashion.

If North American $\underline{A}$. tamarense/catenella/ $\underline{\text { fundyense }}$ are sexually-incompatible, then the evolutionary scenario presented in Chapter 4 is greatly over-simplified. Furthermore, this would suggest that the B gene and LsrDNA sequences have moved laterally (i.e., between distinct organisms in the absence of conventional zygote formation) by some ill-defined mechanism (e.g., viral element). ${ }^{2}$

\section{Molecular Detection of Strains, Species and Genera}

Oligonucleotide probes targeted at rRNA and rDNA are used extensively in the detection of a wide range of organisms. This technology clearly holds for promise as means for rapid detection of

1 Cembella, A.D., Taylor, F.J.R., Therriault, J.-C. (1988). Cladistic analysis of electrophoretic variants within the toxic dinoflagellate genus Protogonyaulax. Botanica Marina 31: 39-51

2 molecular evolutionists' nightmare 
harmful algal species. The challenges that lie ahead will fall under two broad categories: 1) finding sequences that are strain-, speciesand/or genera-specific; and, 2) developing methods to detect such sequences in a manner and time frame relevant to field studies.

RFLP assays are a viable alternative to probes when considering analysis of laboratory cultures (Chapt. 2). Theoretical restriction maps of the $\mathrm{A}$ and $\mathrm{B}$ genes have already been created, and enzymes expected to differentiate the sequences identified. Note that restriction sites within the A and B genes fall on both evolutionarily-conserved and evolutionarily-variable regions (cf. Chapt. 1 and Appendix B). Restriction maps should also be created for the LsrDNA sequences, and RFLP sites identified. RFLP assays could greatly streamline analysis of new isolates: a culture could be harvested, its DNA extracted, Ss and LsrDNA PCR-amplified, and then subjected to a battery of restriction enzymes. In this fashion, a great deal could quickly be learned of an isolates' affinity for a specific group, and at a relatively low cost.

\section{E. Genetic Basis of Toxin Production}

The genetic basis of PSP toxin production is one of the greatest mysteries of Alexandrium biology. An intriguing observation is the phylogenetic tree presented in Chapter 3: some evolutionary lineages of Alexandrium appear to be composed exclusively of toxic isolates, while others appear to be composed exclusively of non-toxic isolates. 
Examining this apparent correlation in greater detail seems well worth the effort. 


\section{Appendix A: Selected Protocols}




\section{Dinoflagellate DNA extraction: Osmotic Shock Lysis}

Chris Scholin March 1992

Note: This protocol is roughly optimized for Alexandrium (thecate spp.), but will also work with naked spp. such as Gymnodinium catenatum (not optimized). It was developed for micro-scale extraction of DNA for use in PCR reactions.

1) remove $\sim 10-15 \mathrm{~mL}$ of an early to mid-log culture and transfer to $15 \mathrm{~mL}$ disposable centrifuge tube.

2) immediately spin at room temperature for $2 \mathrm{~min}$. in an IEC table top centrifuge on setting \#5 using a swinging bucket rotor.

3) remove supernatant by vacuum aspiration, being careful not to aspirateaway the pellet.

Note: if you're processing more than one culture, its advisable to change the pipet between tubes to avoid potential cross-contamination of DNAs.

4) remove any additional supernatant by micropipet.

Note: it's important the pellet be as free as possible from sea water; this increases lysis efficiency.

5) resuspend the pellet in $\sim 217 \mu \mathrm{L}$ of $\mathrm{ddH}_{2} \mathrm{O}$ and transfer to $1.5 \mathrm{~mL}$ centrifuge tube - keep at room temperature.

6) add the following, at room temperature, in the given order:

$25.0 \mu \mathrm{L}$ of $10 \%$ SDS

$5.0 \mu \mathrm{L}$ of $0.5 \mathrm{mM}$ EDTA, $\mathrm{pH} 8.0$

$2.5 \mu \mathrm{L}$ of $1 \mathrm{M}$ Tris-HCL, $\mathrm{pH} 7.5$

$0.5 \mu \mathrm{L} 5 \mathrm{M} \mathrm{NaCl}$ (optional) final conc. $=1 \%$

final conc. $=10 \mathrm{mmM}$ EDTA

final conc. $=10 \mathrm{mM}$ Tris

final conc. $=10 \mathrm{mM} \mathrm{NaCl}$

When adding the SDS, EDTA, and Tris, mix by pipetting and/or "finger vortexing" - Be very careful not to pull up the lysed cells into your pipetter, or you will contaminate other DNA preps and stock reagents!! 
7) extract once with buffered phenol (1:1; i.e., to $\sim 250 \mu \mathrm{L}$ lysis mixture add $250 \mu \mathrm{L}$ phenol); vortex vigorously until emulsion is uniform.

8 ) spin 5 min. in a cold $\left(4^{\circ} \mathrm{C}\right)$ microfuge at max. speed; transfer aqueous (top) phase to fresh tube - leave as much of the interface behind as possible.

Note: on rare occasion, the aqueous phase will be on the bottom. Use color to decide which is the aqueous phase phenol should be spiked with 8-hydroxyquinoline as an antioxidant and colorant; its yellow color will help i.d. the organic phase.

9) extract two-three times with an equal volume of phenol:chloroform:isoamyl alcohol (PCI; 24:24:1); vortex and spin as before, transferring the aqueous phase to a fresh tube after each extraction

Note: by the last PCI extraction, the aqueous phase should be clear, and there should be little to no "goop" at the interface.

10) extract once with an equal volume of chloroform:isoamyl alcohol (CI; 24:1); vortex/spin as before and transfer aqueous phase to a fresh tube

11) place tube on ice after final $C: I$ extraction.

Note: even though the aqueous phase is by now $<250 \mu \mathrm{L}$, continue using $250 \mu \mathrm{L}$ of organic phase for the "1:1" extractions; the same is true for the series of PCIs - use $250 \mu \mathrm{L}$ of organic phase throughout.

12) to precipitate total nucleic acids (RNA \& DNA) that have been extracted add:

$500 \mu \mathrm{L} 100 \%$ ice-cold EtOH ( 2 vol.) $25.0 \mu \mathrm{L} 3 \mathrm{M} \mathrm{NaOAc}$ pH 5.0-5.2 ( 1/10 vol.)

(Note: adj. $\mathrm{pH}$ of $\mathrm{NaOAc}$ with glacial acetic acid)

13) vortex to mix; you may see a mass of DNA "spool-out," but not always.

14) let stand at $-20^{\circ} \mathrm{C}$ for $>2$ hrs. 
15) spin in cold $\left(4^{\circ} \mathrm{C}\right)$ microfuge $10-15 \mathrm{~min}$. at max. speed.

16) remove supernatant with micropipetter

17) rinse pellet with $\sim 0.5 \mathrm{~mL}$ of $80 \% \mathrm{EtOH}$

18) let stand at $-20^{\circ} \mathrm{C}$ for at least $30 \mathrm{~min}$.

Note: DNA samples are probably stable indefinitely under the $80 \%$ ETOH rinse

19) spin in cold $\left(4^{\circ} \mathrm{C}\right)$ microfuge $10-15 \mathrm{~min}$. at max. speed.

20) remove as much supernatant as possible with micropipetter; let pellet air dry for several min.

Note: it's best not to let the pellet completely dry (gets clear) as this sometimes causes problems in the resuspension.

21) resuspend pellet in $10-50 \mu \mathrm{L}$ of $\mathrm{TE} \mathrm{pH} 7.5$ (10mM Tris, 7.5; $1 \mathrm{mM}$ EDTA pH 8.0)

22) dilute sample and read O.D. 260 and $280 \mathrm{~nm}$. The ratio of these should be $~ 1.8-2.2$; calculate concentration of DNA in sample by:

dilu. factor x O.D. @ 260 x 50 ug/ml DNA/1.0 O.D. @260 nm.

22) store resuspended DNA at $-20^{\circ} \mathrm{C}$.

Note: yield will vary depending upon lysis and extraction efficiency; range can be $5-50$ ug. It is also advisable to scan the sample from $~ 320-220 \mathrm{~nm}$; significant $\left(\mathrm{CH}_{2} \mathrm{O}\right)_{\mathrm{n}}$ contamination is indicated by large abs. (greater than peak at 260nm) @ wavelengths between $260-220 \mathrm{~nm}$. Healthy, actively growing cultures will have a low amount of contaminating $\left(\mathrm{CH}_{2} \mathrm{O}\right)_{n}$; old, slow-growing or sickly cultures generally have a high amount of contaminating $\left(\mathrm{CH}_{2} \mathrm{O}\right)_{\text {n. }}$. It helps to transfer your cultures frequently ( once $/ 2$ wks.) prior to extracting the DNA - that way the cells are very happy. Cultures transferred infrequently, and that are just "maintained," don't seem to yield as much DNA.

10/9/92 post script: alternate extraction protocols should be explored. This one worked well for me, but I've a feeling it won't be generally applicable to all dinos - just a thought. C. Scholin 


\section{Hints for PCR Amplification of Alexandrium SsrDNA and LsrDNA, and T/A Cloning of PCR Products}

\section{PCR}

I obtained the best results using Perkin Elmer "GeneAmp Core Reagents." Vent ploymerase (NEB) worked, but not well. The DNA needs to be clean. Low O.D. 260/280 ratio $(<1.8)$ and high $\left(\mathrm{CH}_{2} \mathrm{O}\right)_{\mathrm{n}}$ are recipes for a bad amplification, but sometimes you can get away with it (not recommended). Processing of the cultures is therefore very important. For amplification, dilute an aliquot of concentrated DNA in $\mathrm{ddH}_{2} \mathrm{O}$ (no buffer, no EDTA) to a final concentration of $1 \mathrm{ng} / \mu \mathrm{L}$. Use $1 \mu \mathrm{L}$ of this (1 ng DNA) per $100 \mu \mathrm{L}$ PCR reaction as recommended by Perkin Elmer.

I kept primers in $10 \mathrm{mM}$ Tris $\mathrm{HCl} \mathrm{pH} 7.5$; working stocks at $1.0 \mu \mathrm{M}$

SsrDNA amplifications - use 1.0 -5.0 $\mu \mathrm{L}$ of primer stock/100 $\mu \mathrm{L}$ PCR rxn. LsrDNA amplifications - use $10.0 \mu \mathrm{L}$ of primer stock/100 $\mu \mathrm{L}$ PCR rxn.

\section{T/A cloning}

The factors influencing efficiency of ligation and transformation appeared linked to the homogeneity of the PCR product, the age of purified PCR products and T/A cloning kit batch. Fresh PCR reactions that contained uniform products with essentially no background or low molecular weight contaminants often gave the best cloning results. The latter point is the most important! Low molecular weight contaminants will drive the ligation reaction by swamping vector ends because their effective molar concentration is very high. The efficiency of cloning was also related to the particular batch of T/A cloning kit used; variation in the effectiveness of different kit lots was noted. In fact, by the end of this study, the T/A cloning Kit from Invitrogen was not working very well. The problem seemed to be with the vector. In the future, consider trying the kits from BRL or Pharmacia. 


\section{T/A Plasmid Miniprep (Modified Birnboim): screening clones and preparing template for ds plasmid sequencing}

\section{Scholin 10/91}

This protocol begins after the PCR product has been ligated into a T/A vector and used to transform E. coli. In the Invitrogen T/A cloning strategy, "white colony" = "recombinant vector" (potential insertcontaining) and "blue colony" = "recircularized vector (no insert). Carry one blue colony through the extraction so that you have a negative control plasmid to use in digestion screens (see below).

Solutions:

SOLN 1

$50 \mathrm{mM}$ glucose

$25 \mathrm{mM}$ Tris $\mathrm{HCl} \mathrm{pH}=8$

$10 \mathrm{mM}$ EDTA $\mathrm{ddH}_{2} \mathrm{O}$
$100 \mathrm{~mL}$

$0.9 \mathrm{~g}$ glucose

$2.5 \mathrm{~mL}$ of $1 \mathrm{M}$ Tris $\mathrm{HCl} \mathrm{pH}=8$

$2.0 \mathrm{~mL}$ of $0.5 \mathrm{M}$ EDTA $\mathrm{pH}=8$

$97 \mathrm{~mL}$

filter, autoclave and store at $4{ }^{\circ} \mathrm{C}$

SOLN 2

$0.2 \mathrm{~N} \mathrm{NaOH}$

$1 \%$ SDS

dd $\mathrm{H}_{2} \mathrm{O}$

make fresh each time; hold at room temp.

SOLN 3

$3 \mathrm{M} \mathrm{K}^{+}$-- $5 \mathrm{M}$ Acetate
$10 \mathrm{~mL}$

$0.34 \mathrm{~mL}$ of $6 \mathrm{~N} \mathrm{NaOH}$

$1.0 \mathrm{~mL}$ of $10 \%$ SDS

$8.66 \mathrm{~mL}$
$100 \mathrm{~mL}$

$60 \mathrm{~mL}$ of $5 \mathrm{M} \mathrm{K}^{+}$Acetate

$11.5 \mathrm{~mL}$ glacial acetic acid

$28.5 \mathrm{~mL}$ dd $\mathrm{H}_{2} \mathrm{O}$

mix, filter and store at $4^{\circ} \mathrm{C}$

\section{Protocol}

1) Pick white colony and inoculate into $2 \mathrm{~mL} \mathrm{LB}+\mathrm{Kan}$; grow overnight

2) Transfer $1.5 \mathrm{~mL}$ to eppendorf (epp.) tube (microcentrifuge tube); save remainder of culture for freeze-down (I usually leave the $0.5 \mathrm{ML}$ of culture in the refrigerator until I've finished screening the clones, then make freeze-downs of the positives). 
3) Spin $1.5 \mathrm{~mL}$ of culture in epp. tube $30 \mathrm{sec} ., 4^{\circ} \mathrm{C}$, max. speed $(\sim 12,000 \mathrm{xg})$ in a microfuge.

4) Remove as much media as possible by vacuum aspiration; place tube on ice.

5) Add $100 \mu \mathrm{L}$ ice-cold SOLN 1; vortex vigorously; place tube on ice.

6) Add $200 \mu \mathrm{L}$ freshly prepared SOLN 2; mix by gently inverting $5 \mathrm{X}$; place tube on ice.

7) Add $150 \mu \mathrm{L}$ pre-chilled SOLN 3; mix by inversion; vortex gently upside-down for $10 \mathrm{sec}$; hold on ice 3-5 min.

8) Spin tube 5 min., $4^{\circ} \mathrm{C}$, max. speed $(\sim 12,000 \mathrm{~g})$ in a microfuge

9) Carefully transfer supernatant to a new tube containing $720 \mu \mathrm{L} 100 \%$ EtOH; hold at room temp. 2 min.

10) Spin tube 5 min., $4{ }^{\circ} \mathrm{C}$, max. speed $(\sim 12,000 \mathrm{xg})$ in a microfuge; discard supernatant (I typically do this by vacuum aspiration, but it requires care that you don't lose the pellet!)

11) Rinse pellet in $\sim 1 \mathrm{~mL}$ ice-cold $80 \%$ EtOH (I typically leave the pellets in the rinse at least $30 \mathrm{~min}$. at $-20^{\circ} \mathrm{C}$ )

12) Spin as in (8); carefully remove supernatant by vacuum aspiration ; allow pellet to air dry $\sim 10 \mathrm{~min}$ (it's best not to let the pellet completely dry, as this sometimes causes problems in the rsp; speed vacing may cause loss of some of the pellet).

13) Resuspend in $50 \mu \mathrm{L}$ TE (7.5) + DNase-free RNase A [ $1 \mathrm{~mL} \mathrm{TE}+10$ uL $10 \mathrm{mg} / \mathrm{mL}$ RNase A (Sigma; prepared as described in spec sheet)].

14) Screening clones: use $\sim 1 \mu \mathrm{L}$ per restriction digest; size clones, determine which carry an insert of correct size; use the negative control plasmid (from blue colony) as reference in addition to normal size standards. Store minis at $-20^{\circ} \mathrm{C}$; make freeze downs of corresponding positive cultures. 
15) Sequencing clones: use $10-30 \mu \mathrm{L}$ of mini prep per sequencing reaction (see sequencing protocol); $30 \mu \mathrm{l}$ works well for an insert of $700 \mathrm{bp}$ - for larger inserts you may be able to use less, for smaller inserts you may have to use more. When sequencing pooled clones, I combine aliquots of each of the mini preps to yield a final volume of $30 \mu \mathrm{L}$. Some preps sequence well, others don't.

\section{Notes:}

Processing: I have found that I can process a maximum of 48 clones/day. When processing 48:

- getting preps to $80 \%$ EtOH rinse stage takes $\sim 4 \mathrm{hrs}+$

- $1 \mathrm{hr}$. break

- remove rinse, rsp., and restriction digestion takes $\sim 2 \mathrm{hrs}$

- loading mega agarose gel takes $\sim 1 \mathrm{hr}$.

Total time from 48 cultures to agarose gel run $\sim 8 \mathrm{hrs}$.

Digestion screens: I size inserts by digesting with a single enzyme and resolving the products by conventional agarose gel electrophoresis. When doing many cuts, I make a master mix of $\mathrm{ddH}_{2} \mathrm{O}$, buffer and enzyme and add $9 \mu \mathrm{l}$ of that master to $1 \mu \mathrm{L}$ of aliquoted miniprep (final rxn vol $=10$ $\mu \mathrm{L}$ ). I try to adjust enzyme concentration so that each rxn receives $\sim 1$ unit of enzyme. Digestions are allowed to proceed $\sim 1 \mathrm{hr}$, then loaded onto a gel and typically run $\mathrm{O} / \mathrm{N}$ at low voltage. The next morning, I check the gel, determine which clones are positive and make freeze downs of the remaining culture. 


\section{dsDNA Sequencing of Recombinant T/A Plasmids}

\section{Scholin 10/91}

Note: the following protocol is used in conjunction with the modified Birnboim plasmid mini prep of $1.5 \mathrm{~mL}$ of culture; plasmids should be resuspended in $50 \mu \mathrm{L}$ of TE +RNase. Sequencing reagents come from United States Biochemical Corp. (USB): "Sequenase V. 2.0 sequencing kit;" the isotope is from Amersham. The protocol is roughly optimized for an insert of $\sim 700 \mathrm{bp}$. in a plasmid of $\sim 2.9 \mathrm{Kbp}$.

\section{1) Denaturation/precipitation of plasmid template}

in a $0.5 \mathrm{~mL}$ tube:

- combine $30 \mu \mathrm{L}$ of miniprep plasmid and $30 \mu \mathrm{L}$ of $0.6 \mathrm{~N} \mathrm{NaOH}$

- mix gently and let stand 5 min. at room temp.

- neutralize by the addition of $9 \mu \mathrm{L} 2 \mathrm{M}$ NH $4 \mathrm{OAc}(\mathrm{pH}=4.5)$

(note: filter sterilize $2 \mathrm{M} \mathrm{NaOAc}$ after adjusting $\mathrm{pH}$ )

- add $12 \mu \mathrm{L} \mathrm{ddH} \mathrm{H}_{2} \mathrm{O}$

- ppt. by addition of $225 \mu \mathrm{L}$ of $100 \% \mathrm{EtOH}$; let stand at least $2 \mathrm{hrs}$. at -20 oC

- spin tube 10 - 15 min., 4 o C, max. speed $(\sim 12,000 \mathrm{~g})$ in a microfuge; discard supernatant (I typically do this by careful micropipetting)

- rinse pellet in 70\% EtOH (I typically let the rinse proceed at least $30 \mathrm{~min}$. at $-20^{\circ} \mathrm{C}$, and often times begin the rinse the night before I intend to run the sequencing reaction)

- spin as before; remove as much supernatant as possible; air dry pellets until DNA is completely dried (pellet is clear; note relative position of pellet so that when you begin the hybridization step you know approximately where to add hyb mix and primer to rsp pellet) 


\section{2) Hybridization}

to dried pellet add the following in the given order:

- $8 \mu \mathrm{L}$ primer $(0.5 \mathrm{pmol} / \mathrm{uL}$ in $10 \mathrm{mM}$ TrisHCl $\mathrm{pH}=7.5)$

$-2 \mu \mathrm{L}$ rxn buffer (USB Sequenase V. 2.0 sequencing kit)

mix; let stand $10 \mathrm{~min}$ at $37^{\circ} \mathrm{C}$

3) Preparing labeling mix

combine the following immediately before use:

$\mathrm{ddH}_{2} \mathrm{O}$

100mM DTT (USB)

diluted labeling mix (USB)*

$35 \mathrm{~S}$ dATP $(10 \mu \mathrm{Ci} / \mu \mathrm{L})$

Sequenase (v 2.0; USB)

Pyrophosphatase(USB; optional) for $1 \mathrm{rxn}$

$0.7 \mu \mathrm{L}$

$1.0 \mu \mathrm{L}$

$2.0 \mu \mathrm{L}$

$1.0 \mu \mathrm{L}$

$0.3 \mu \mathrm{L}$ for 3 rxns

$2.1 \mu \mathrm{L}$

$3.0 \mathrm{uL}$

$6.0 \mu \mathrm{L}$

$3.0 \mu \mathrm{L}$

$1.0 \mu \mathrm{L}$

$0.5 \mu \mathrm{L}$

\section{Notes:}

- * dilute USB labelling mix: $1 \mu \mathrm{L}$ concentrated dNTPs $+4 \mu \mathrm{L} \mathrm{ddH_{2 } \mathrm { O }}$

- I typically aliquot isotope: $3 \mu \mathrm{L} / 0.5 \mathrm{~mL}$ tube $(\sim 30 \mu \mathrm{Ci})$ and store frozen to avoid excessive freeze-thaw cycles of the isotope stock.

- I generally run 3 sequencing reactions in tandem; ie., 3 templates are carried through the protocol in quick succession, with overlaps in their ddNTP termination incubations (see below). Do not attempt to process more than 3, or else you will not have enough time to initiate all of the labelling and ddNTP termination steps and still be able stop the reactions at the appropriate time.

- you can probably use half the amount of isotope called for in the protocol, making up the difference with $\mathrm{dd}_{2} \mathrm{O}$.

- you may also be able to use less sequenase (or diluted), though the success of that may be a function of the template and your specific reaction conditions; thus far I have not tried to reduce the amount of sequenase. 
- pyrophosphatase is optional; for my sequences, it seems to help reduce background. Pyrophosphatase and sequenase can be mixed and stored together, but I have not explored this option (see USB Sequenase instruct.)

\section{3) Labelling reaction}

- add $5 \mu \mathrm{L}$ of labelling mix to $10 \mu \mathrm{L}$ hybridization reaction; mix by gentle pipetting

- incubate $1 \mathrm{~min}$. at room temp.

4) ddNTP termination reactions

- add $3.5 \mathrm{uL}$ labelled template to $2.5 \mu \mathrm{L}$ of each ddNTP

(ie., $3.5 \mathrm{uL}$ labelled template to $2.5 \mu \mathrm{L}$ ddC, A, T, G.)

- incubate at $37{ }^{\circ} \mathrm{C}$ for $10 \mathrm{~min}$. (an extra min or so won't hurt)

5) Stop reaction

- add $4 \mu \mathrm{L}$ stop mix (USB); store at $-20{ }^{\circ} \mathrm{C}$ until running (storage for several days does not reduce resolution of the products

\section{Additional notes on processing many reactions:}

Prior to beginning the sequencing reactions, I remove up to 24 denatured templates from the $70 \% \mathrm{EtOH}$ rinse, dry and cap them, and store them in the frige until I'm ready to process them (all are intended to be processed non-stop; I don't recommend drying more templates than you intend to sequence in one sitting).

While the templates are drying, I thaw all reagents for sequencing (except isotope), label tubes, dilute labelling mix, etc.

I typically process 3 templates at a time. All are removed from the frige, and carried through the initialization of hybridization. During the hybs, I aliquot ddNTPs, thaw a tube of isotope, and make up labelling mix (adding sequenase and pyrophosphatase just prior to the completion of the hybridization reactions). It's not a problem if the hybs incubate for longer than $10 \mathrm{~min}$. 
Labelling mix is added to the first template and incubated for $1 \mathrm{~min}$. During this, I remove the aliquoted ddNTPs from ice. After the $1 \mathrm{~min}$ labelling step, I aliquot labelled template into each of the four ddNTPs, place the tubes at $37{ }^{\circ} \mathrm{C}$, start the timer, and immediately begin processing the second template. Likewise, the third template follows the second. By the time the third template has been labelled and is undergoing ddNTP termination, the first template will be ready for stop mix (usually I have $\sim 2$ min. between initiating the third template's dd termination and completion of the first template's dd termination. Addition of stop mix then proceeds through the first, second, then third templates. I generally have about 1-2 min. between additions of stop mix for each of the templates. A 3 channel timer works well for keeping track of the status of each of the 3 templates. If you try to process more than 3 templates in a series, the timing of the various steps will get out of sink, and you may lose your mind trying to keep track of all the reactions and their various states of completion!

It takes $\sim 30$ min. \pm to process 3 templates (not counting set-up time).

Effectiveness of sequencing individual clones varies depending on the particular preparation; reactions with only $10 \mu \mathrm{L}$ of plasmid sometimes give weak sequencing ladders.

10/13/92 post script: I gave this protocol to someone, and they now tell me they process 4 templates at a time. Also, she tells me that sequenase can be diluted, and you can use half the amnount of isotope called for - this should be explored since it represents a significant cost savings. C. Scholin. 


\section{Magnetic Bead Preparation of Biotinylated PCR Products for Sequencing}

DeLong 11/91

Materials/Reagents

-Dynal Dynabeads M-280 Streptavidin

-magnetic particle concentrator (Dynal MPC-E)

[Dynal, Inc.; Great Neck N.Y.; ph. (516) 829-0039]

-wash buffer

$150 \mathrm{mM} \mathrm{NaCl}$

$100 \mathrm{mM}$ Tris $\mathrm{HCl} \mathrm{pH} 7.6$

$-6 \mathrm{M} \mathrm{NaOH}$

- biotinylated PCR product

set up PCR reactions as always (forward and reverse primers); use only one PCR primer that is biotinylated:

to sequence forward rxns. (coding strand) use $3^{\prime}$ reverse biotinylated PCR primer

to sequence reverse rxns. (non-coding strand) use 5' forward biotinylated PCR primer

if you wish to sequence both strands, you'll need two separate PCR reactions - one for the forward rxns, and one for the reverse rxns. Drawing this out on paper helps!! You must keep track of the polarity of the differnt strands!!!

- Sequenase V. 2.0 sequencing kit (USB)

\section{Template Preparation}

- each PCR reaction is good for $\sim 2-3$ sequencing rxns

- use $20 \mu \mathrm{L}$ beads per sequencing rxn 
- if one template is going to be sequenced with several different primers, it can be processed with the the beads in a single tube:

for example: you have 1 PCR rxn and want to sequence it with three different primers, mix the PCR rxn with $60 \mu \mathrm{L}$ beads, follow the protocol, then aliquot bead/template complex into three different tubes $(20 \mu \mathrm{L}$ each), and sequence....

\section{Protocol}

1) aliquot beads to $1.5 \mathrm{~mL}$ tube ( $20 \mu \mathrm{L}$ beads per sequencing rxn, per template)

2) was twice with $200 \mu \mathrm{L}$ wash buffer:

- add solution, vortex, concentrate beads using MPC-E to so that wash can be removed with micropipetter

3) resuspend beads in original vol. of wash buffer

4) add PCR product to beads - mix - let stand @ room temp. with occassional shaking (or put on rotator) 15-30 min.

5) concentrate beads, remove supernatant (excess PCR product)

Note: excess PCR product can be saved: store @ -200 C.

6) wash twice with $200 \mu \mathrm{L}$ wash buffer

7) add $200 \mu \mathrm{L} 0.15 \mathrm{M} \mathrm{NaOH}$ to denature the DNA

(make fresh from 6M stock: $9.75 \mathrm{~mL}$ dd $\mathrm{H}_{2} \mathrm{O}+0.25 \mathrm{~mL} 6 \mathrm{M} \mathrm{NaOH}$ )

8) vortex - let stand 5 min.

9) concentrate beads, discard supernatant, and wash with $200 \mu \mathrm{L} 0.15 \mathrm{M}$ $\mathrm{NaOH}$

10) wash an additional three times, each with $200 \mu \mathrm{L}$ dd $\mathrm{H}_{2} \mathrm{O}$ 
11 ) if template has been prepared for more than one sequencing rxn, resuspend beads in dd $\mathrm{H}_{2} \mathrm{O}$ ( $20 \mu \mathrm{L}$ per sequencing reaction) and alliquot 20 $\mu \mathrm{L}$ portions to separate tubes.

12) concentrate particles; remove as much supernatant as possible

13) to each $20 \mu \mathrm{L}$ beads/ssDNA complex add:

$7.0 \mu \mathrm{L}$ dd $\mathrm{H}_{2} \mathrm{O}$

$2.0 \mu \mathrm{L}$ USB Sequenase buffer

$1.0 \mu \mathrm{L}$ sequencing primer $(1.0 \mu \mathrm{M}$ or $4.4 \mu \mathrm{g} / \mathrm{mL})$

14) proceed with standard USB Sequenase V. 2.0 protocol

Note: when loading magnetic bead sequencing reactions on a gel, pull sample from the top of the liquid - if you pull it from the bottom, lots of the magnetic bead particles will get loaded too, and cause the gel lane to lose resolution 


\section{Alexandrium RNA Extraction: $\mathrm{LiCl} 2$ Precipitation}

Mega prep - C. Scholin 9/89 (modified Hasting's)

Mini-prep - C. Scholin 11/90

\section{Alexandrium Cell Prep/Storage for RNA Extractions}

Note: use only disposable polypropylene centrifuge tubes!!

Mega prep cell harvest

Mid-late log cells (2-5,000 cells $/ \mathrm{mL})$ sholud be harvested from carboys using a Nitex bag, pelleted in $50 \mathrm{~mL}$ disposable centrifuge tubes, remove supernatant and immersed tubes in liquid N2. Knock the pellet out, wrap in plastic weighing dish, and tap with a hammer to shatter the pellet. Place fragments immediately into $15 \mathrm{~mL}$ disposable centrifuge tubes and reimmerse in liquid $\mathrm{N}_{2}$. Store cells in liquid $\mathrm{N}_{2}$ until processing for RNA.

Mini prep cell harvest

Concentrate $\sim 2 \mathrm{~L}$ of mid-late log cells $(2-5,000$ cells $/ \mathrm{mL})$ on Nitex mesh, backwash into $50 \mathrm{~mL}$ centrifuge tube, pellet and remove supernatant. Resuspend cells in $\sim 10 \mathrm{~mL}$ sea water, tranfer to $15 \mathrm{~mL}$ centrifuge tube, pellet and remove supernatant. Immerse cells in liquid N2. Store in liquid $\mathrm{N}_{2}$ until processing for RNA.

\section{$\underline{\text { RNA Extraction }}$}

Before beginning, practice using the $\mathrm{N}_{2}$ bomb!!

Preparation of Stock sloutions

\section{WEAR GLOVES - YOUR HANDS ARE FULL OF RNase!!!}

Prepare all stocks using DEPC-treated Mill-Q $\mathrm{H}_{2} \mathrm{O}$, baked glassware (or pre-sterilized, disposable glassware) and sterilized, disposable plasitcware.

DEPC-treated Mill-Q H2O : (prepare in bulk) $1.0 \mu \mathrm{L}$ DEPC per 1mL Mill$\mathrm{Q} \mathrm{H}_{2} \mathrm{O}$; stir - autoclave. 
Stock reagents/solutions:

it pays to by ultra-pure, RNase-free reagents

keep them separate, wear gloves when you touch them, and only use baked-out spatulas, or sterile pipets when handling the material.

"Left overs" on a spatula go in the trash, not back in the reagent container!

- 0.5 M NaCit (sodium citrate) $\mathrm{pH} 7.0$

- 0.25 M EDTA pH 8.0

- 0.25 M EGTA pH 8.0

- $8.0 \mathrm{M} \mathrm{LiCl} 2$

- filter $0.22 \mu \mathrm{M}$ (Corning disposable); autoclave

- 4.0 $\mathrm{M} \mathrm{NH} 4 \mathrm{OAc} \mathrm{pH} 5.0$

- filter $0.22 \mu \mathrm{M}$ (Corning disposable)

- Sarkosyl (detergent)

- B-mercaptoethanol (BME)

- Guanidine Isothiocyanate (GuSCN)

- Buffered Phenol:Chloroform (1:1; P/C)

phenol: add $0.1 \%$ 8-hydroxyquinoline

buffer with Tris base

final buffer: $10 \mathrm{mM}$ Tris $\mathrm{pH}$ 8.0, 0.1\% $\mathrm{BME}$

- Chloroform

- Guanidine Isothiocyanate Extraction buffer (GIB)

(prepare immediately before use - room temp.)

$5.0 \mathrm{M} \mathrm{GuSCN}$

$25.0 \mathrm{mM}$ NaCit pH 7.0

$25.0 \mathrm{mM}$ EDTA $\mathrm{pH} 8.0$

25.0 mM EGTA pH 8.0

$0.5 \%$ Sarkosyl (w/vol)

$2.0 \% \mathrm{BME}$

Note: this is dangerous soultion!! use only in hood - wipe up spills promptly! 


\section{Mega prep RNA Extraction}

This prep is designed for $\sim \mathrm{g}$ of frozen cells.

1) briefly thaw cells

2) resuspend cells in $\sim 22 \mathrm{~mL}$ of GIB - vortex until completely resuspended

3) load into $\mathrm{N}_{2}$ bomb - pressurize to $\sim 2,000 \mathrm{psi}$ - let stand $\sim 10 \mathrm{~min}$

Note: when using the $\mathbf{N}_{2}$ bomb always wear protective clothing, and protective eye wear (preferably a face shield!!). The solution you are working with is highly toxic and will melt your skin (literally). THINK!!!

4) release most (not all!)of the lysate into fresh $50 \mathrm{~mL}$ tube set aside; release the remainder into a second tube.

This is the most dangerous step!! Be careful, when the cell slurry has passed, a rush of $\mathrm{N}_{2}$ will come out!! Keep the tube pointed away from you and always do this in a hood!!!

5) mellow out - now the hard part is over - split your lysate into two tubes; it doesn't hurt to have a look at the slurry, just to make sure the cells are toasted.

6) extract lysate with an equal vol. of P/C

- vortex vigorously!!

- sep. phases by centrifugation in an IEC table top centrifuge at maximum speed for $5 \mathrm{~min}$ at room temperature

7) place tube on ice, transfer aqueous phase to fresh cold tube( a Pasteur pipet works well for this), repeat $\mathrm{P} / \mathrm{C}$ extraction two more times (interface should be free of goo - if it isn't, keep doing P/C extraction until it is; generally 3-4 does the trick)

Note: you lose a lot of nucleic acid at the interface - if you're concerned about yield, re-extract organic phase with several $\mathrm{mL}$ of GIB - transfer from one to the next so that all organic phases get "rinsed" with the same few $\mathrm{mL}$ of GIB - combine aqueous phases before step 8 . 
8) extract twice with an equal vol. of chloroform

9) following the final extraction, estimate the volume of the aqueous phase; split evenly among several baked, Corex centrifuge tubes; keep on ice.

10) precipitate the nucleic acids by the addition of 2.5 volumes of $100 \%$ $\mathrm{EtOH}, 1 / 20$ volume of $4 \mathrm{M} \mathrm{NH} 4 \mathrm{OAc}$ (pH 5.0); cover with parafilm, mix well

10) chill at -70 o C for $>1 \mathrm{~h}$.

11) remove parafilm caps! and centrifugation at $\sim 4{ }^{\circ} \mathrm{C}$ for $20 \mathrm{~min}$ at 10,000 rpm in a Beckman model J2-21 centrifuge fitted with a JA-20 rotor (or equivalent - be careful of $\mathrm{xg}$ force - if you spin $>10 \mathrm{~K}$ as above, the tubes may break).

12) discard supernatants; briefly drain the pellets (invert on clean "BenchKote")

13) resuspend in DEP-treated $\mathrm{ddH}_{2} \mathrm{O}$ and transfer to fresh, baked Corex tubes

Note: gentle heating may be required $\left(\sim 50^{\circ} \mathrm{C}\right)$; work the pellet into solution by pipetting and vortexing. Try to keep the volume to a minimum - I usually got each pellet into $8 \mathrm{~mL}$ (see next step). Also it is essential that the pellet be completely resuspended before proceeding with $\mathrm{LiCl}_{2}$ precipitation step!! Once the nucleic acid is in solution, put the tube on ice!

14) adjust $\mathrm{LiCl}_{2}$ to $2 \mathrm{M}$ - be precise!! Cover tube with parafilm

e.g., resuspend pellet in $8 \mathrm{~mL} \mathrm{dd \textrm {H } _ { 2 } 0}$

$11 \mathrm{~mL}$ final vol. $\times 2 \mathrm{M} \mathrm{LiCl} 2=2.75 \mathrm{~mL}$ $8 \mathrm{M} \mathrm{LiCl} 2$

So, to $8 \mathrm{~mL}$ resuspended pellet add $2.75 \mathrm{~mL} 8 \mathrm{M} \mathrm{LiCl}_{2}$ and $0.25 \mathrm{~mL}$ $\mathrm{ddH}_{2} 0$; final vol. $=11 \mathrm{~mL}$, final $\left[\mathrm{LiCl}_{2}\right]=2 \mathrm{M}$.

15) let stand $\mathrm{O} / \mathrm{N}$ on ice (pack in crushed ice - put in cold room)

16) collect precipitates as in step 11 
17) drain pellets; rinse tube walls and pellet with ice-cold $2 \mathrm{M} \mathrm{LiCl}_{2}$ discard rinse.

Note: when rinsing the RNA pellets, and decanting the supernatants, do it over a clean, baked-out mini-beaker, so that it if the pellet comes free and slips out, it goes into an RNAse-free beaker, not the sink!! Remember what a pain it was working with the GIB buffer want to do it again? If you are simultaneously processing more that one strain's RNA, use separate beakers, just in case....

18) resuspend pellets in DEP-treated ddH20

19) you can either stop here, quantify, and $\mathrm{EtOH} \mathrm{ppt}$, or repeat another $\mathrm{LiCl}_{2}$ precipitation. If another $\mathrm{LiCl}_{2}$ precipitation is repeated, you need only leave it on ice for $>2 \mathrm{hr}$ (not $\mathrm{O} / \mathrm{N})$. If you EtOH ppt., remove a sample for a check gel first! Be sure to quantify before precipitating as well, so that you can estimate amt. RNA/mL EtOH ppt.

Note: RTase sequencing worked well with only one $\mathrm{LiCl}_{2} \mathrm{pptn}$.

20) store as EtOH ppt @-70C

21) should yield $500 \mu \mathrm{g}$ - $1 \mathrm{mg}$ total RNA, depending on how efficient the extractions were

\section{Mini prep RNA Extraction}

This prep is designed for $\sim 2 \mathrm{~L}$ mid-log culture, harvested and frozen in liquid N2. It follws the mega prep procedure, except that cells are resuspended and in $5.5-6.0 \mathrm{~mL}$ GIB, time of pressurization is reduced to $5 \mathrm{~min}$ and extractions are done in $15 \mathrm{~mL}$ tubes. Initial total nucleic acid precipitates can be resuspended in $2 \mathrm{~mL} \mathrm{DEP}$-treated $\mathrm{ddH}_{2} 0$; to adjust $\mathrm{LiCl}_{2}$ to $2 \mathrm{M}$ : add $690 \mu \mathrm{L} 8 \mathrm{M} \mathrm{LiCl}_{2}$ and $69 \mu \mathrm{L} \mathrm{ddH} 20$. If the pellet won't go in $2 \mathrm{~mL}$, try $4 \mathrm{~mL}$. In the latter case, to adjust $\mathrm{LiCl}_{2}$ to $2 \mathrm{M}$ : add 1.375 $\mathrm{mL} 8 \mathrm{M} \mathrm{LiCl}_{2}$ and $134 \mu \mathrm{L} \mathrm{ddH}_{2} 0$.

Yield is $\sim 200 \mu \mathrm{g} \pm$

Final note: nutrient-stressed cells and/or senescent cells yield less than wonderful RNA using this procedure - you may need to go to $\mathrm{CsCl}$ gradients, or try two $\mathrm{LiCl}_{2}$ pptns. 


\section{Reverse Transcriptase-Mediated Sequenceing of rRNA}

M. Herzog 10/89

Preparation: Stock sloutions and 35 S end-labelled primer

WEAR GLOVES - YOUR HANDS ARE FULL OF RNase!!!

Prepare all stocks using DEPC-treated Mill-Q $\mathrm{H}_{2} \mathrm{O}$, baked glassware (or pre-sterilized, disposable glassware) and sterilized, disposable plasitcware.

DEPC-treated Mill-Q H2O : (prepare in bulk) $1.0 \mu \mathrm{L}$ DEPC per $1 \mathrm{~mL}$ Mill$\mathrm{Q} \mathrm{H}_{2} \mathrm{O}$; stir - autoclave.

5x annealing buffer: $500 \mathrm{mM} \mathrm{KCl}, 200 \mathrm{mM}$ Tris- $\mathrm{HCl}(\mathrm{pH} 7.3)$

5x RTase buffer: $250 \mathrm{mM}$ Tris- $\mathrm{HCl}(\mathrm{pH} 7.3), 250 \mathrm{mM} \mathrm{KCl}$, $50 \mathrm{mM} \mathrm{MgCl} 2,50 \mathrm{mM}$ DTT

dNTP mix: $2 \mathrm{mM}$ each of dATP, dGTP,dCTP, dTTP

ddNTPs: ddATP - 0.8mM; ddGTP - 0.2mM; ddCTP - $0.2 \mathrm{mM}$; ddTTP - $0.8 \mathrm{mM}$

5' end-labelled primer: (unlabelled primer must have 5'-OH)

1) combine: $10 \mu \mathrm{L}$ primer $(50 \mathrm{ng} / \mu \mathrm{L}=500 \mathrm{ng})$

$10 \mu \mathrm{L}$ ATP $\left[\gamma{ }^{35} \mathrm{~S}\right](10 \mu \mathrm{Ci} / \mu \mathrm{L}=100 \mu \mathrm{Ci})$

$2.5 \mu \mathrm{L} 10 \mathrm{x}$ kinase buffer (500mM Tris-HCL pH 7.5, 100mM MgCl2, 50mM DTT)

$2.0 \mu \mathrm{L}$ T4 Kinase

$0.5 \mu \mathrm{L}$ DEPC-treated Mill-Q $\mathrm{H}_{2} \mathrm{O}$

2) incubate $\sim 3 \mathrm{hrs}$ at $37^{\circ} \mathrm{C}$, then add:

$3.0 \mu \mathrm{L} 0.5 \mathrm{M}$ EDTA pH 8.0

61.0 $\mu$ L DEPC-treated Mill-Q $\mathrm{H}_{2} \mathrm{O}$

$1.0 \mu \mathrm{L}$ tRNA $(2 \mathrm{mg} / \mathrm{mL})$

$10.0 \mu \mathrm{L} 3 \mathrm{M} \mathrm{NaOAc}$ pH 5.0

$300 \mathrm{uL} 100 \%$, ice-cold EtOH 
3) let stand at $-70^{\circ} \mathrm{C}$ for $\sim 30 \mathrm{~min}-1 \mathrm{hr}$

4) spin in cold microfuge $(12,000 \mathrm{xg})$ for $15 \mathrm{~min}$

5) remove supernatant with pipette - blot onto "BenchKote" and dispose of in radioactive trash

6) resuspend pellet in $50.0 \mu \mathrm{L}$ DEPC-treated Mill-Q $\mathrm{H}_{2} \mathrm{O}$

7) EtOH ppt: $5.0 \mu \mathrm{L} 3 \mathrm{M} \mathrm{NaOAc} p H 5.0,100 \mathrm{uL} 100 \%$, ice-cold EtOH

8) let stand at $-70^{\circ} \mathrm{C}$ for $\sim 30 \mathrm{~min}-1 \mathrm{hr}$

9) spin, remove supernatant as before

10) rinse tube/pellet with $\sim 200 \mu \mathrm{L}$ of $80 \%$, ice-cold EtOH - let stand $\sim 30$ min at $-20^{\circ} \mathrm{C}$ (or perform another EtOH pptn.)

11) spin, remove supernatant as before, then resuspend pellet in $50.0 \mu \mathrm{L}$ DEPC-treated Mill-Q $\mathrm{H}_{2} \mathrm{O}$

12) determine specf. activity of primer: count $1.0 \mu \mathrm{L}$

$$
\begin{aligned}
& \text { specf. activity }=\mathrm{cpm} / 10 \mathrm{ng}=0.1 \mathrm{cpm} / \mathrm{ng}=10^{2} \mathrm{cpm} / \mu \mathrm{g} \\
& \text { should get } \sim 10^{7} \mathrm{cpm} / \mu \mathrm{g}
\end{aligned}
$$

13) makes enough primer for $\sim 10$ sequencing rxns; best if used within $1-2$ wks.

10/13/92 post script: may want to explore the use of spin columns should be much easier than differential precipitations, and will probably give a better yield. If you try this, omit tRNA, $\mathrm{NaOAc}$, and EtOH at step (2), and proceed immediately to column centrifugation. Be careful in the spin steps - the solution is radioactive!! Also, the labelling protocol works with ATP $\left[\gamma^{32} \mathrm{P}\right]$ or $\left[\gamma^{33 P}\right]$. C. Scholin. 


\section{rRNA Sequencing}

Remove an aliquot of the RNA EtOH precipitate, transfer to a microcentrifuge tube, collect precipitate by centrifugation, and resuspended in DEPC-treated $\mathrm{ddH}_{2} \mathrm{O}$ to a final concentration of $\sim 1 \mathrm{mg} \mathrm{mL}^{-1}$.

1) in one tube combine:

$5.0 \mu \mathrm{L}(2 \mu \mathrm{g} / \mu \mathrm{L})$ total RNA =

$2.5 \mu \mathrm{L} 5 \mathrm{x}$ annealing buffer $=$

total vol. $=\frac{5.0 \mu \mathrm{L}}{12.5 \mu \mathrm{L}}$
$10 \mu \mathrm{g}$ total RNA

$1 \mathrm{x}$ annealing buffer

2) heat to $90^{\circ} \mathrm{C}$ for $2 \mathrm{~min}$

3) allow to cool to room temp. in styrofoam block for $\sim 10 \mathrm{~min}$ (slow cool)

4) during primer/template annealing, aliquot $1 \mu \mathrm{L}$ of each ddNTP into its own tube - leave on ice.

5) place annealed mix ("master mix" from step 3) on ice and add:

$5.0 \mu \mathrm{L} 5 \mathrm{x}$ RTase buffer

$5.0 \mu \mathrm{L}$ dNTP mix

$1.0 \mu \mathrm{L}$ AMV RTase (25units/ $\mu \mathrm{L})$

6) mix well, be careful not to introduce bubbles

7) add $4 \mu \mathrm{L}$ of the master mix to each base-specific termination reaction (from step 4)

8) incubate termination reactions at $37-45^{\circ} \mathrm{C}$ for $30 \mathrm{~min}$

Note: warmer temperatures reduce the probabilities of nonspecific ("unviversal" terminations); some preparations of RTase are heat stable, allowing for incubations as high as $55^{\circ} \mathrm{C}$. Check this out!

9) chase termination reactions by adding $1.0 \mu \mathrm{L}$ of dNTP mix +1 unit RTase \{i.e., add $1.0 \mu \mathrm{L}$ of: [ $24 \mu \mathrm{L}$ dNTP mix $+1.0 \mu \mathrm{L}$ RTase (25 units/ $\mu \mathrm{L})]\}$ 
10) incubate reactions at $37-45^{\circ} \mathrm{C}$ (same temp. as in step 8) for an additional $15 \mathrm{~min}$

11) add $1.0 \mu \mathrm{L}$ DNase-free RNase $(100 \mu \mathrm{g} / \mathrm{mL})$

12) incubate reactions at $37-45^{\circ} \mathrm{C}$ (same temp. as in step 8) for an additional $15 \mathrm{~min}$

13) add 4-5 $\mu \mathrm{L}$ stop dye (EDTA, formamide, xylene cyanol see Asubel et al. - Current Protocol in Molecular Biology)

14) store reactions at $-20^{\circ} \mathrm{C}$ no longer than several days to 1 week before running on gel 
Appendix B: SsrDNA Notes 


\section{Intra-A and Intra-B Gene Variation}

The terms "A gene" and "B gene" really refer to two distinct "families" of molecules. Clones within each family do exhibit minor sequence differences that are distinct from "A/B heterogeneity." Based on available sequence information, clones of either the A family or the B family are $\sim 99 \%$ identical. In contrast, A/B interfamily similarity is $\sim 97.8 \%$. Observed heterogeneity within the A and B gene families is listed below:

\section{Intra-A gene Variation}

\begin{tabular}{|c|c|c|}
\hline$\underline{\text { lignment position }}^{1}$ & sequence & $\underline{n}^{3}$ \\
\hline 425 & G/A & G univ. consv. (4) \\
\hline 643 & $\mathrm{C} / \mathrm{T}$ & variable $(0)$ \\
\hline $672 *$ & $\mathrm{~A} / \mathrm{C}$ & variable $(0)$ \\
\hline 820 & $\mathrm{~A} / \mathrm{C}$ & variable $(0)$ \\
\hline 1006 & $\mathrm{~T} / \mathrm{C}$ & $\mathrm{T}$ dino/apicom/cil (2) \\
\hline $1196 * *$ & $\mathrm{~A} / \mathrm{G}$ & A univ. consv. (4) \\
\hline
\end{tabular}

\section{Intra-B gene Variation}

$\begin{array}{ccc}\text { alignment position }^{1} & \frac{\text { sequence difference }^{2}}{\text { T/C }} & \frac{\text { position conservation }^{3}}{\text { variable }(0)} \\ 523 & \mathrm{~T} / \mathrm{G} & \text { variable }(0) \\ 813 & \mathrm{~A} / \mathrm{G} & \text { A euk. consv. (3) } \\ 831 & \mathrm{~T} / \mathrm{G} & \text { variable }(0) \\ 832 & \mathrm{~T} / \mathrm{C} & \text { variable }(0) \\ 1061 & \mathrm{~T} / \mathrm{C} & \text { T dino. consv. (1) }\end{array}$

1 relative to $\mathrm{A} / \mathrm{B}$ alignment shown in Chapt. 1; "*:" $\mathrm{A}$ is expressed in rRNA, C is not; "**:" same SsrDNA clone as "*" - possible A gene pseudogene??

2 presented as reported nucleotide (Chapt.1) / intrafamily variant

3 using same categories as those in Chapt. 1 (cf. Fig. 1, Chapt. 1) 
Table B.1. List of restriction enzymes, predicted cleavage sites and expected products of digestion for the A and B genes from A. fundyense (GtCA29) (last updated 7/92). Cut sites refer to the nucleotide distal to the cleavage and are realtive to the position in the A gene. Hae III and Xba I cleave the genes in identical locations.

Sequence Recognition Expected Products

\begin{tabular}{|c|c|c|c|c|c|}
\hline Enzyme & Cut Site & A gene & B gene & A gene & B gene \\
\hline Asel & 863 & + & - & $\begin{array}{l}938 \\
862\end{array}$ & 1797 \\
\hline BsaAI & $\begin{array}{r}539 \\
1466\end{array}$ & - & $\begin{array}{l}+ \\
+\end{array}$ & 1800 & $\begin{array}{l}924 \\
538 \\
335\end{array}$ \\
\hline BsePI & $\begin{array}{r}432 \\
1466\end{array}$ & $\begin{array}{l}+ \\
+\end{array}$ & $\begin{array}{l}+ \\
-\end{array}$ & $\begin{array}{r}1034 \\
431 \\
335\end{array}$ & $\begin{array}{r}1366 \\
431\end{array}$ \\
\hline BssI & $\begin{array}{r}19 \\
301\end{array}$ & $\begin{array}{l}+ \\
+\end{array}$ & $\begin{array}{l}+ \\
-\end{array}$ & $\begin{array}{r}1500 \\
282 \\
18\end{array}$ & $\begin{array}{r}1779 \\
18\end{array}$ \\
\hline DpnI & $\begin{array}{r}13 \\
128 \\
821 \\
970 \\
991 \\
1001 \\
1069 \\
1797\end{array}$ & $\begin{array}{l}+ \\
+ \\
+ \\
+ \\
+ \\
+ \\
+ \\
+\end{array}$ & $\begin{array}{l}+ \\
+ \\
- \\
+ \\
+ \\
+ \\
+ \\
+\end{array}$ & $\begin{array}{r}693 \\
668 \\
149 \\
128 \\
115 \\
21 \\
12 \\
10 \\
4\end{array}$ & $\begin{array}{r}840 \\
667 \\
128 \\
115 \\
21 \\
12 \\
10 \\
4\end{array}$ \\
\hline Eco105I & 539 & - & + & 1800 & $\begin{array}{r}1259 \\
538\end{array}$ \\
\hline HaeIII & $\begin{array}{r}787 \\
1281\end{array}$ & $\begin{array}{l}+ \\
+\end{array}$ & $\begin{array}{l}+ \\
+\end{array}$ & $\begin{array}{l}786 \\
520 \\
494\end{array}$ & $\begin{array}{l}786 \\
520 \\
491\end{array}$ \\
\hline HinfI & $\begin{array}{r}251 \\
380 \\
1191 \\
1258 \\
1598\end{array}$ & $\begin{array}{l}- \\
+ \\
+ \\
+ \\
+\end{array}$ & $\begin{array}{l}+ \\
+ \\
+ \\
+ \\
+\end{array}$ & $\begin{array}{r}811 \\
340 \\
250 \\
203 \\
129 \\
67\end{array}$ & $\begin{array}{l}808 \\
407 \\
250 \\
203 \\
129\end{array}$ \\
\hline Hpall & $\begin{array}{r}301 \\
384 \\
1108 \\
1671\end{array}$ & $\begin{array}{l}- \\
+ \\
+ \\
+\end{array}$ & $\begin{array}{l}+ \\
+ \\
+ \\
+\end{array}$ & $\begin{array}{l}724 \\
563 \\
383 \\
130\end{array}$ & $\begin{array}{r}722 \\
562 \\
300 \\
83 \\
130\end{array}$ \\
\hline
\end{tabular}


Table B.1. Continued

$\frac{\text { Enzyme }}{\text { MaeI }}$

Sequence Recognition Expected Products

\begin{tabular}{|c|c|c|c|c|c|}
\hline \multirow[t]{5}{*}{ MaeI } & 593 & - & + & 844 & 592 \\
\hline & 845 & + & + & 547 & 546 \\
\hline & 1014 & + & + & 214 & 251 \\
\hline & 1040 & + & + & 169 & 214 \\
\hline & 1587 & + & + & 26 & $\begin{array}{r}168 \\
26\end{array}$ \\
\hline \multirow[t]{3}{*}{ MaeII } & 538 & - & + & 1392 & 852 \\
\hline & 1393 & + & + & 408 & 537 \\
\hline & 1465 & - & + & & 336 \\
\hline \multirow{7}{*}{ MaeIII } & 109 & + & + & 588 & 694 \\
\hline & 211 & + & + & 411 & 411 \\
\hline & 359 & + & + & 296 & 295 \\
\hline & 467 & + & - & 148 & 148 \\
\hline & 1055 & + & + & 108 & 108 \\
\hline & 1351 & + & + & 108 & 102 \\
\hline & 1762 & + & + & 102 & 39 \\
\hline \multirow{8}{*}{ MboI } & 11 & + & + & 693 & 840 \\
\hline & $\begin{array}{l}11 \\
126\end{array}$ & + & + & 668 & 667 \\
\hline & 819 & + & - & 149 & 128 \\
\hline & 968 & + & + & 128 & 115 \\
\hline & 989 & + & + & 115 & 21 \\
\hline & 999 & + & + & 21 & 10 \\
\hline & 1667 & + & + & 10 & 10 \\
\hline & 1795 & + & + & 10 & 6 \\
\hline \multirow[t]{4}{*}{ NsiI } & 57 & + & + & 1681 & 1523 \\
\hline & 120 & + & + & 63 & 155 \\
\hline & 275 & - & + & 56 & 63 \\
\hline & & & & & 56 \\
\hline \multirow[t]{2}{*}{ PmaCI } & 1466 & - & + & 1800 & 1462 \\
\hline & & & & & 335 \\
\hline \multirow[t]{5}{*}{ RsaI } & 240 & - & + & 928 & 925 \\
\hline & 505 & + & + & 504 & 265 \\
\hline & 708 & + & + & 203 & 239 \\
\hline & 1636 & + & + & 165 & 203 \\
\hline & & & & & 165 \\
\hline SspI & 813 & - & + & 1800 & 985 \\
\hline
\end{tabular}




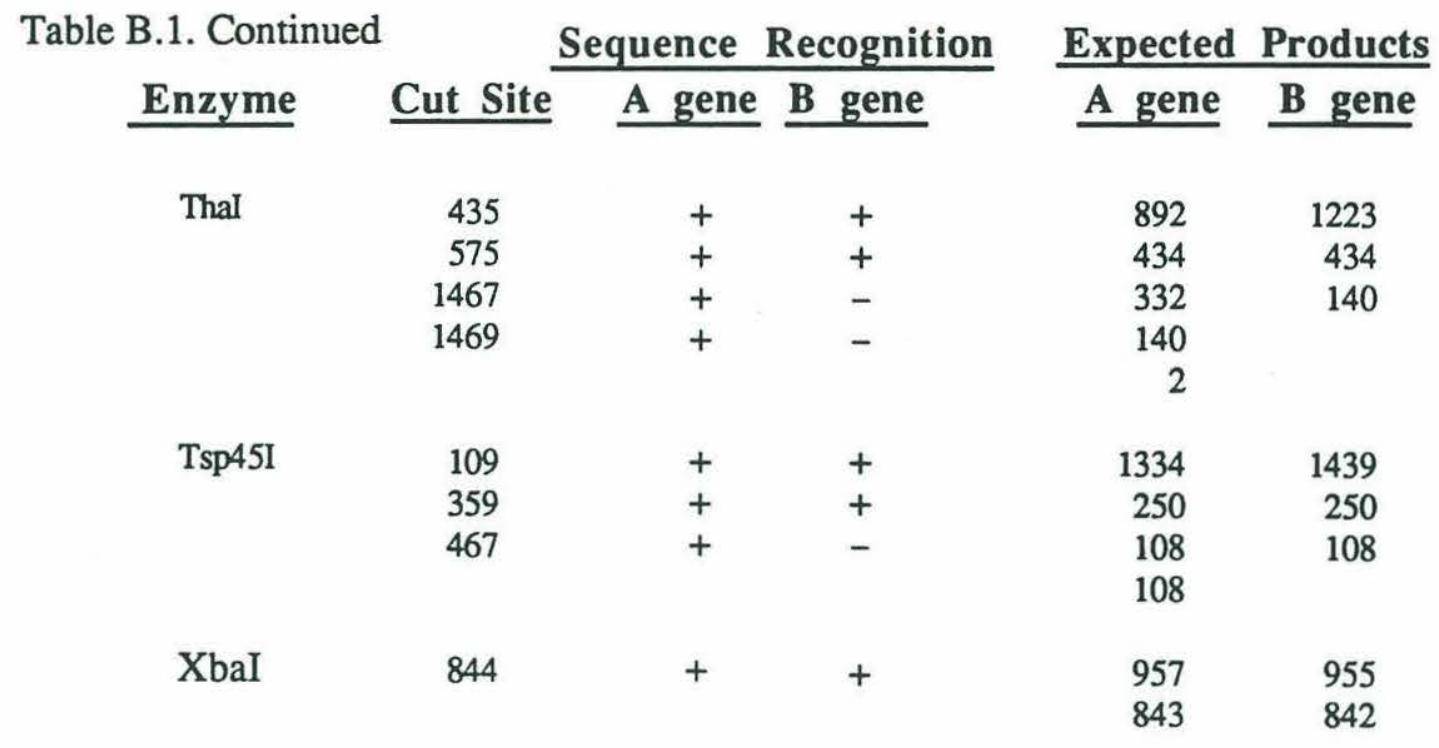




\section{Characterization of Larger, Minor SsrDNA PCR Products Found in "Group I" Alexandrium Isolates}

\section{SUMMARY}

Unexpectedly large SsrDNA amplification products are typical of Alexandrium Group I isolates. Attempts to characterize the nature and origin of these molecules were made using various combinations of PCR amplification primers. In addition, larger SsrDNA products from a single Group I isolate were characterized in detail by cloning and sequencing methodologies. Results indicate that the "larger SsrDNA PCR products" from this one Group I isolate are due to rearranged SsrDNA A and B genes. It is likely the same or similar rearrangements exist in other Group I organisms. As such, it may be possible to use these molecules as population-specific markers.

\section{INTRODUCTION}

Larger, minor SsrDNA PCR products were observed in all eastern North American $\underline{\mathrm{A}}$. $\underline{\text { tamarense/fundyense }}$ and some Japanese A. tamarense (SsrDNA RFLP "Group I;" cf. Chapt. 2, Fig. 2 and Table 2 for SsrDNA RFLP group definitions). Initially, the larger products were considered artifacts of the amplification reaction, or thought to possibly result from a contaminating source of DNA. However, several observations led to the hypothesis that these products were in fact of Alexandrium origin. First optimization the amplification conditions failed to eliminate the apparently spurious molecules from 
Group I isolates, but otherwise resulted in highly specific reactions (Chapt. 2). Second, the aberrant products were found in all in eastern North American isolates of $\underline{A}$.tamarense/ $\underline{\text { fundyense, }}$ as well as a number of Japanese strains. These cultures came from laboratories in Northeastern U.S., Tasmania, and Japan. Thus, cultures isolated by a number of researchers in different laboratories located in several countries all displayed the same, larger SsrDNA PCR amplification products. Third, all isolates that yield the lager SsrDNA PCR products also carry the B gene (Chapt. 2). Finally, a contaminating source of DNA from culture media was ruled out, since all cultures were maintained with common stocks of sea water and nutrients, and only DNA from a specific subset of cultures gave rise to the larger products. Microscopic observations also failed to reveal the presence of microeukaryotes in any of the cultures that yielded the lager SsrDNA PCR products. Taken together, these observations suggested that the lager molecules were indeed of Alexandrium origin, and could possibly serve as another independent, populationspecific character.

Though the products were clearly correlated with specific subset of Alexandrium and showed promise as a fine-scale population indicator, the nature of these molecules and their relationship to the rDNA transcriptional unit was a mystery. I considered the possibility that a small portion of rDNA repeats are rearranged and/or carry insertions. This report focuses on my effort to address this possibility experimentally using a combination of techniques employed in Chapts. 1-4. 


\section{MATERIALS and METHODS}

\section{$\underline{\text { Cultures }}$}

The cultures used in this study are: AFNFA4 (‥ Group I), GtCA29 (‥ fundyense; Group I), GtMP (‥ fundyense; Group I) GtPP01(ㅁ․ tamarense; Group I), GtPP06(․․ tamarense; GroupI), PW06 (‥ tamarense; Group II), Pgt 183 and PE1V (both $\underline{A}$. tamarense; Group III), ATBB01 (‥ tamarense; Group III) and ACPP01 (A. catenella Group III). Details of the isolates' geographic origins, culturing and DNA extraction are found in Chapt. 2 (see also Appendix A). Throughout this report, the cultures will be referred to by strain designation.

$\underline{\mathrm{PCR}}$

Complete SsrDNA PCR amplifications were carried out as noted in Chapt. 2. In those cases where magnetic bead sequencing was used, either the forward or reverse primer was biotinylated to prepare template for reverse or forward sequencing reactions, respectively.

"Cistron amplifications" ("cistron amp;" Fig. B.1) are those PCR reactions that used the 690F SsrDNA primer ("forward;" complementary to Dictyostelium discoideum SsrRNA nucleotide 
positions 892-906; Sogin and Gunderson 1987) ${ }^{1}$ and D2C LsrDNA primer ("reverse;" complementary to Prorocentrum micans LsrRNA 733-714; Lenaers et al. 1989). ${ }^{2}$ PCR reaction conditions were the same as those in Chapt. 2, except that the thermal cycle was modified to: denaturing at $92^{\circ} \mathrm{C}-1.5 \mathrm{~min}$; cooling to $37^{\circ} \mathrm{C}-1.0 \mathrm{~min}$; annealing at $37^{\circ} \mathrm{C}-2.0 \mathrm{~min}$; warming to $72^{\circ} \mathrm{C}-2.0 \mathrm{~min}$; and, extension at $72^{\circ} \mathrm{C}$ - 3.0 min. This cycle was repeated 4 times, and then changed to: cooling to $42^{\circ} \mathrm{C}-1.0 \mathrm{~min}$; annealing at $42^{\circ} \mathrm{C} 2.0 \mathrm{~min}$; extension at $72^{\circ} \mathrm{C}-2.5 \mathrm{~min}$, with an auto extension $(5 \mathrm{sec} / \mathrm{cycle})$. The latter cycle was repeated 26 times. "Cistron amps" were attempted using DNA from all cultures listed above.

"Partial SsrDNA amplification" ("partial SsrDNA amp;" Fig. B.1) are those PCR reactions that used the 690F SsrDNA primer ("forward") and EukR (eukaryotic-conserved "reverse" primer; Medlin et al. 1988). ${ }^{3}$ The thermal cycle used was as follows: denaturing at $92^{\circ} \mathrm{C}-1.5 \mathrm{~min}$; cooling to $42^{\circ} \mathrm{C}-1.0 \mathrm{~min}$; annealing at $42^{\circ} \mathrm{C} 2.0 \mathrm{~min}$; warming to $72^{\circ} \mathrm{C}-2.0 \mathrm{~min}$; extension at $72^{\circ} \mathrm{C}-2.0$ min. The cycle was repeated 30 times with an auto extension (5

1 Sogin, M. L., Gunderson, J.H. 1987. Structural diversity of eukaryotic small subunit ribosomal RNAs: evolutionary implications. Endocytobiology III. Ann. N.Y. Acad. Sci. 503:125-39.

2 Lenaers, G., Maroteaux, L., Michot, B., Herzog, M. (1989). Dinoflagellates in evolution. A molecular phylogenetic analysis of large subunit ribosomal RNA. J. Mol. Evol. 29:40-51.

3 Medlin, L., Elwood, H.J., Stickel, S. \& Sogin, M.L. 1988. The characterization of enzymatically amplified eukaryotic 16S-like rRNA-coding regions. Gene 71:491-9. 
sec/cycle). "Partial SsrDNA amps" were attempted using DNA from GtPP01.

Sequencing/Cloning

Magnetic bead sequencing, as well as T/A cloning and plasmid sequencing were carried out as described in Chapts. 3 and 4 (protocols are found in Appendix A). The following SsrDNA sequencing primers were used: "forward" reactions (coding strand) 690F (see above) and 920F (complementary to D. discoideum SsrRNA nucleotide positions 1125-1141); "reverse" (non-coding strand) EukR (see above), 1400R (complementary to D. discoideum SsrRNA nucleotide positions 1719-1705) and 1055R (complementary to $\underline{\mathrm{D}}$. discoideum SsrRNA nucleotide positions 1276-1262; Sogin and Gunderson 1987).

\section{RESULTS and DISCUSSION}

The characteristic Group I "larger SsrDNA amplification products" appear as one (e.g., Chapt. 2, Fig. 2), or sometimes two (Scholin and Anderson 1992) 4 , bands depending on how the gel is run. High voltage agarose gel electrophoresis favors their resolution as two, possibly more, distinct bands. Sizing these products indicates

\footnotetext{
${ }^{4}$ Scholin, C.A. \& Anderson, D.M. 1992. Population analysis of toxic and nontoxic Alexandrium species using ribosomal RNA signature sequences. In: Smayda, T.J. \& Shimizu, Y. [Eds.] Fifth International Conference on Toxic Marine

Phytoplankton. Elsevier, New York. (in press).
} 
that the larger "single band" is approximately $300 \mathrm{bp}$ greater than the expected SsrDNA product, while the larger "doublet" is approximately 200 and 400 bp greater than the expected SsrDNA product.

Two amplification strategies were used in an attempt to discern if the minor products were rearrangements of a ribosomal cistron, or the result of an insertion into a specific portion of the SsrDNA sequence (Fig. B.1). In the first, "cistron amps" were attempted from $690 \mathrm{~F}$ to D2C. The resulting product is predicted to represent 3 ' half of the SsrDNA, the 5.8S rDNA and associated flanking regions, and approximately $700 \mathrm{bp}$ of the LsrDNA - a total of approximately 2.2 Kbp. Results of this amplification indicated that two, minor products larger than those that expected were clearly visible in GtPP01 and possibly GtPP06 (both Group I), but absent in PW06 (Group II), 183, PE1V, and ATBB01 (all Group III). The amplification failed entirely for AFNFA4, GtCA29, GtMP and ACPP01; poor DNA preparations were implicated in this failure (data not shown). The size and characteristics of the additional bands seen in the GtPP01 "cistron amp" are consistent with those noted in routine Group I SsrDNA amplifications. This indicated that a potential rearrangement or insertion was located between 690F and D2C (Fig. B.1). In an attempt to localize the site(s) of such rearrangements, DNA from GtPP01 was amplified using 690F and EukR ("partial SsrDNA amp;" Fig. B.1). Surprisingly, two major products emerged from the reaction: the expected fragment of $\sim 900 \mathrm{bp}$, and a larger product of $\sim 1200 \mathrm{bp}$ (Fig. B.2). The intensity and clarity of the $\sim 1200 \mathrm{bp}$ product was 
unexpected, yet its size was in the range of that expected for the "larger" SsrDNA amplification product (i.e., was 300 bp grater than the expected product). Therefore, it seemed possible that the larger bands observed in SsrDNA amplifications of Group I isolates were at least partially due to insertions in the 3' half of some SsrDNA. However, evidence supporting this possibility was weak for two reasons. First, amplification reactions were not optimized; the 1200 bp fragment could have been an artifact. Second, DNA from other Alexandrium isolates had not been subjected to the same amplification strategy; consequently, the correlation (or lack thereof) between the 1200 bp fragment and SsrDNA RFLP groups (I-III) was totally unknown.

Further investigation of these issues was deemed too costly, too time consuming and potentially of little use in the overall context of the thesis. It seemed probable that nature of the aberrant SsrDNA amplification products from Group I isolates would remain a mystery, with the following exceptions: 1) they were known to occur in a particular group of cultures; 2) they were always seen in conjunction with the B gene; and 3) they potentially arose because of an insertion(s) in the $3^{\prime}$ half of some portion of the organisms' SsrDNAs. Evidence supporting the latter point was admittedly weak. 


\section{$690 \mathrm{~F}>$}

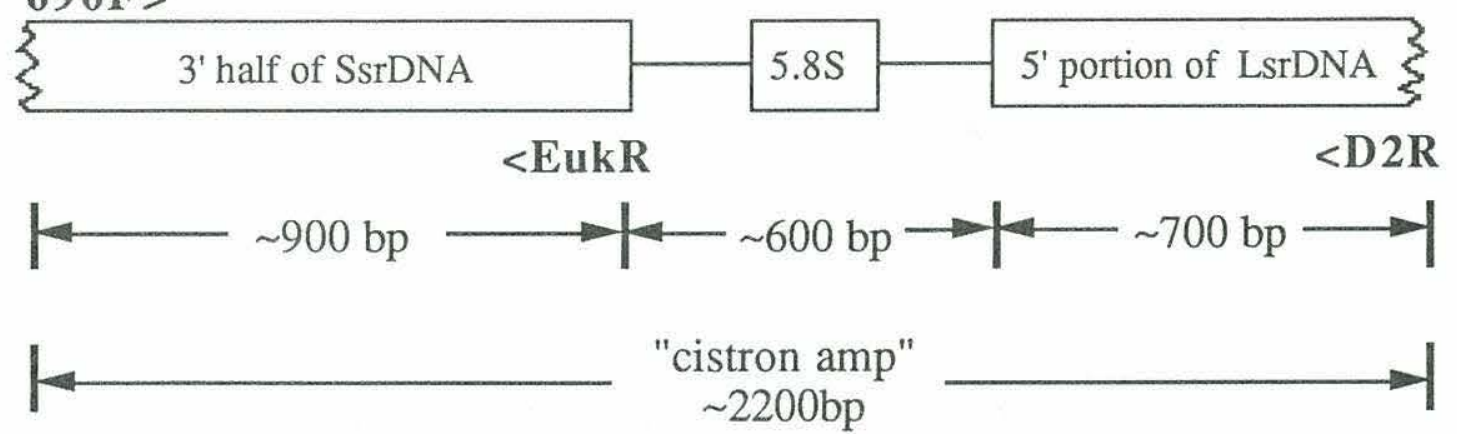

"partial SsrDNA amp"
$\sim 900$ bp

Figure B.1. PCR amplification strategy for determining approximate location and boundaries of SsrDNA insertion(s) relative to 5.8S and 5' end of LsrDNA. "Cistron amp" used 690F and D2R primers; "partial SsrDNA amp" used 690F and EukR primers.

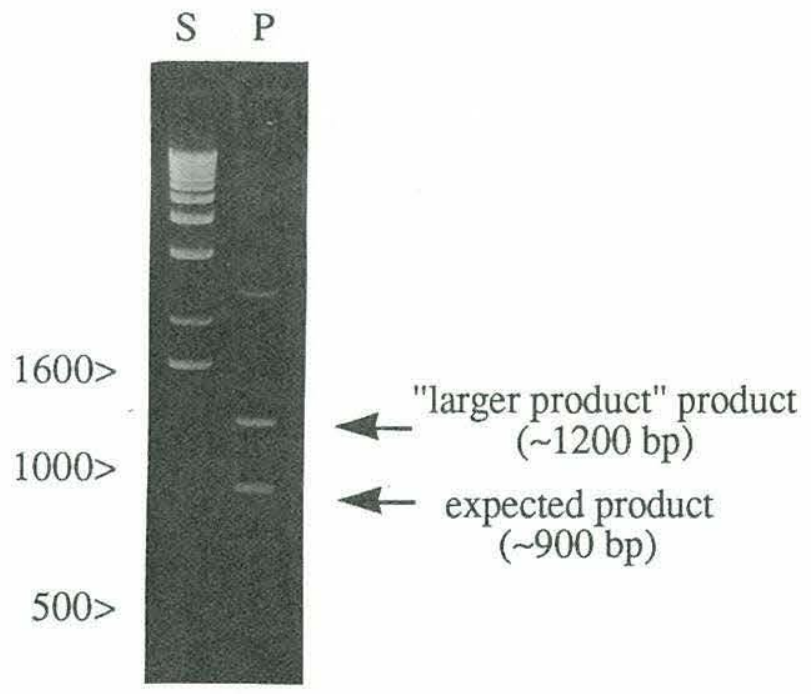

Figure B.2. Agarose gel of PCR products from "partial SSrDNA amp" using GtPP01 DNA. "S" = size standards; sizes of relevant standards are shown to the left and are in bp. "P" = PCR product. Arrows denote the unexpected $1200 \mathrm{bp}$ band and the expected band of $\sim 900 \mathrm{bp}$. 
Interest in the possibility that an insertion was in fact present in some copies of Group I SsrDNAs was rekindled during the search for B-like genes (Chapter 4). Sequencing of SsrDNA PCR products using the magnetic bead technique revealed a minor sequence inserted at position $\sim 1156$ in $\underline{\mathrm{A}}$. fundyense (GtCA29; Group I) that was distinct from $\mathrm{A}$ and $\mathrm{B}$ gene variation, and not present in any of the other isolates tested for B-like sequences (Fig. B.3). This sequence was not observed during resolution of GtCA29's A and B genes (Chapt. 1). The appearance of a heretofore unknown heterogeneity ("inserted sequence") at a defined point within GtCA29's SsrDNA could only be explained by the fact that the entire PCR pool was sampled using the magnetic bead strategy. It seemed likely that GtCA29's minor, larger SsrDNA PCR products were the source of this heterogeneity for several reasons. First, the fact that the "inserted sequence" was very faint suggested that the element(s) responsible for it had to be a minor component of the PCR pool. Second, the "inserted sequence" was absent in isolates that have homogeneous SsrDNA amplification products. Third, the "inserted sequence" appeared at position that placed it within the PCR amplification primers used during initial characterizations of Group I's larger SsrDNA amplification products. Given these observations, it seemed possible that the two major products observed in GtPP01's "partial SsrDNA amp" might represent: 1) native SsrDNA (900 bp); and, 2) that which carries the $300 \mathrm{bp}$ insert (1200 bp) responsible for Group I "larger SsrDNA PCR products." Thus, GtPP01's "partial SsrDNA amp" products were cloned and sequenced in an renewed search for an insertional element in Group I SsrDNA. 


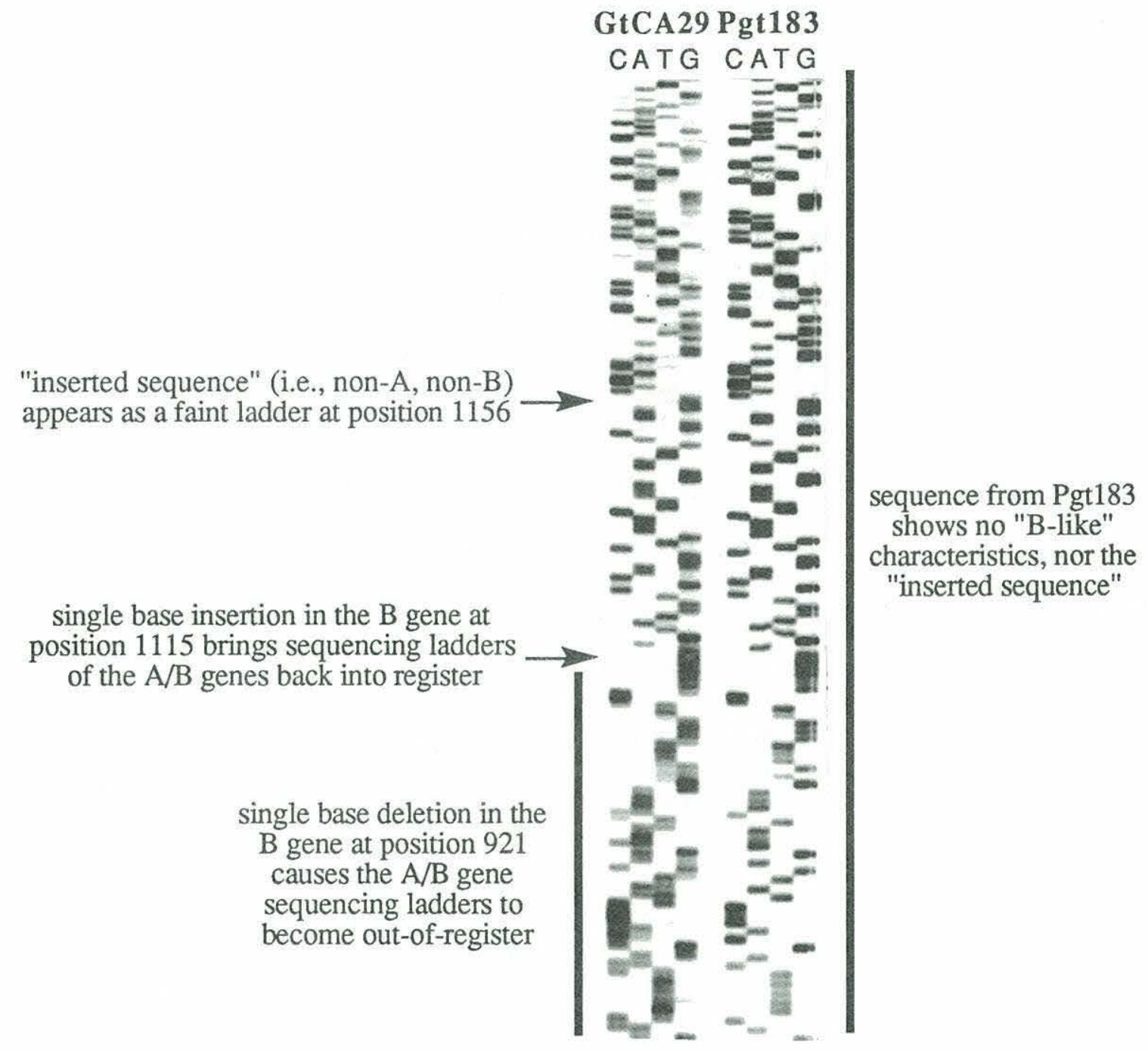

Figure B.3. Magnetic bead sequencing of SsrDNA from GtCA29 and Pgt183 using the 690F primer. 
The results of these experiments were surprising, and for a long time perplexing. First, as a control, a portion of GtPP01's SsrDNA was sequenced using the magnetic bead technique. Based on what was observed in SsrDNA from GtCA29, 690F- and 920F-primed reactions were predicted to reveal the $5^{\prime}$ end of the insert. As expected, GtPP01's PCR-amplified SsrDNA contains A/B gene heterogeneity and the faint "inserted sequence" at position 1156 (Fig. B.4), identical to that in GtCA29 (Fig. B.3). When a "partial SsrDNA Large Clone" (i.e., plasmid containing the 1200 bp fragment) from GtPP01 was sequenced with the 690F and 920F primers, it surprisingly showed the same heterogeneities, except that the "inserted sequence" no longer appeared faint but instead was equal in intensity to the A/B ladders (Fig. B.4)! This was very confusing: a single plasmid clone carried a 1200 bp fragment bordered by $690 \mathrm{~F}$ and EukR that had characteristics of the A gene, the B gene and the "insert." Results of the reverse sequencing reactions were equally puzzling. First, in an attempt to map the 3 ' terminus of the insert, total GtPP01 SsrDNA was PCR-amplified, and sequenced with the magnetic bead technique using EukR-, 1400R- and 1055R-primed reactions. This revealed $\mathrm{A} / \mathrm{B}$ gene heterogeneities, but no "inserted sequence." The latter result was unexpected: if the insert was a unique, non-ribosomal segment of DNA (e.g., viral element), at least one of the three "reverse-primed" reactions should have encountered its 3 ' end. Furthermore, when the GtPP01 "partial SsrDNA Large Clone" was sequenced using the EukR and 1400R primes, the sequence showed no evidence of $A / B$ heterogeneity but instead appeared indicative of the B gene only (Fig. B.5). The primers used 


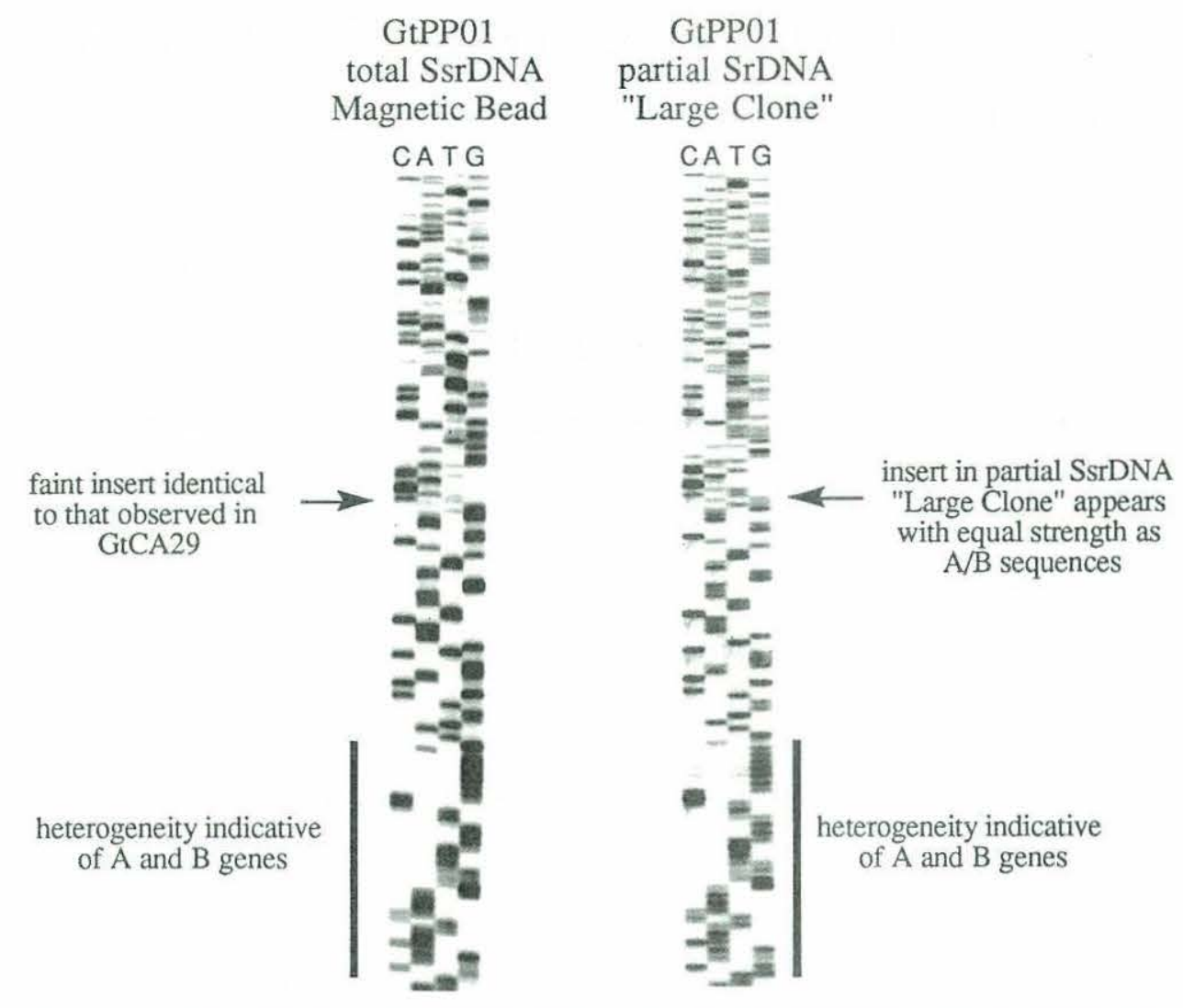

Figure B.4. Comparison of PCR-amplified GtPP01 SsrDNA sequenced with the magnetic bead technique, and GtPP01 partial SsrDNA "Large Clone" sequenced as double stranded plasmid.

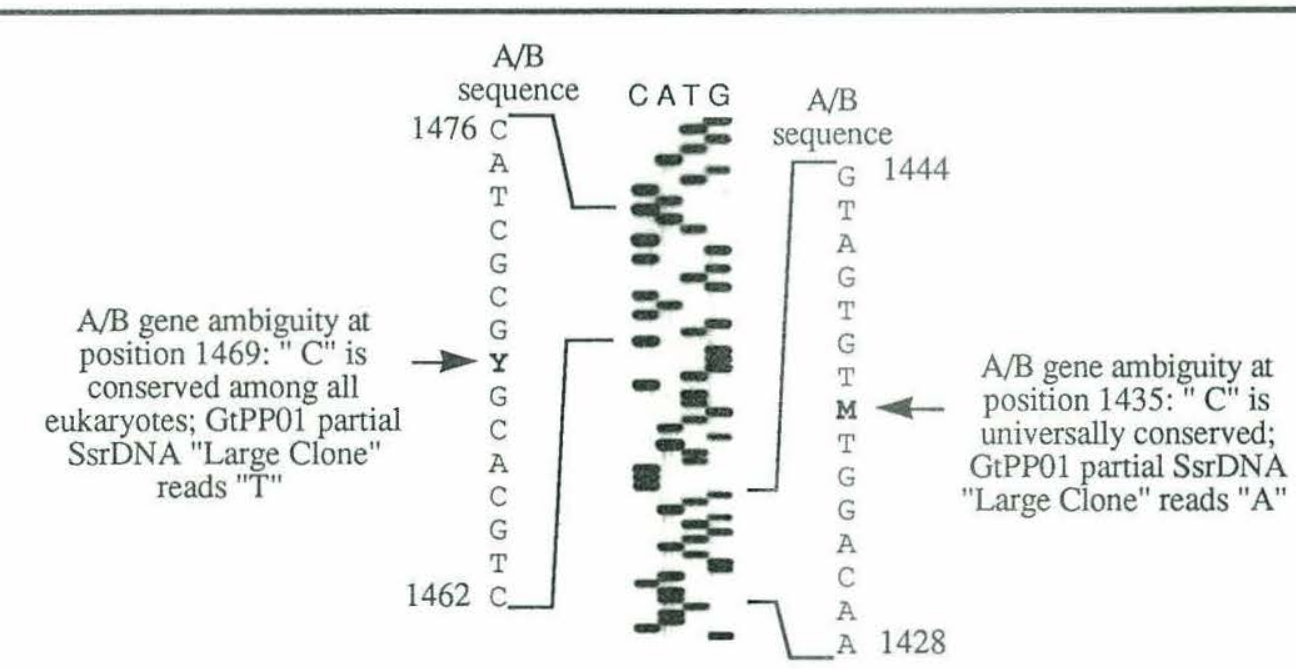

Figure B.5. Sequence of GtPP01 partial SsrDNA "Large Clone" using the 1400R primer (the image has been inverted so that it reads as the complement) and comparison to $\mathrm{A} / \mathrm{B}$ gene sequences; numbers refer to the postion in the $\mathrm{A} / \mathrm{B}$ gene alignment (cf. Chapt. 1). Arrows denote $\mathrm{A} / \mathrm{B}$ gene ambiguites $(\mathrm{M}=\mathrm{C}$ or $\mathrm{A} ; \mathrm{Y}=\mathrm{C}$ or $\mathrm{T})$. Note that in both cases the SsrDNA "Large Clone" violates highly conserved sequence positions. 
in these sequence determinations, their relative locations in the $\mathrm{A}$ and B genes and a deduction of the "partial SsrDNA Large Clone's" structure is shown in Fig. B.6.

The only explanation for the sequence characteristics observed in both magnetic bead sampling of the PCR pool, and the "partial SsrDNA Large Clone" is a $300 \mathrm{bp}$ direct repeat of a portion of the SsrDNA (Fig. B.6). This can exist in two configurations: a fragment of the A gene inserted into the $\mathrm{B}$ gene, or the $3^{\prime}$ end of the $\mathrm{B}$ gene attached to a truncated $\mathrm{A}$ gene. In both cases the $3^{\prime}$ end of the "partial SsrDNA Large Clone" is expected to be of B gene origin, since it harbors universal and eukaryotic position violations (Fig. B.5). 


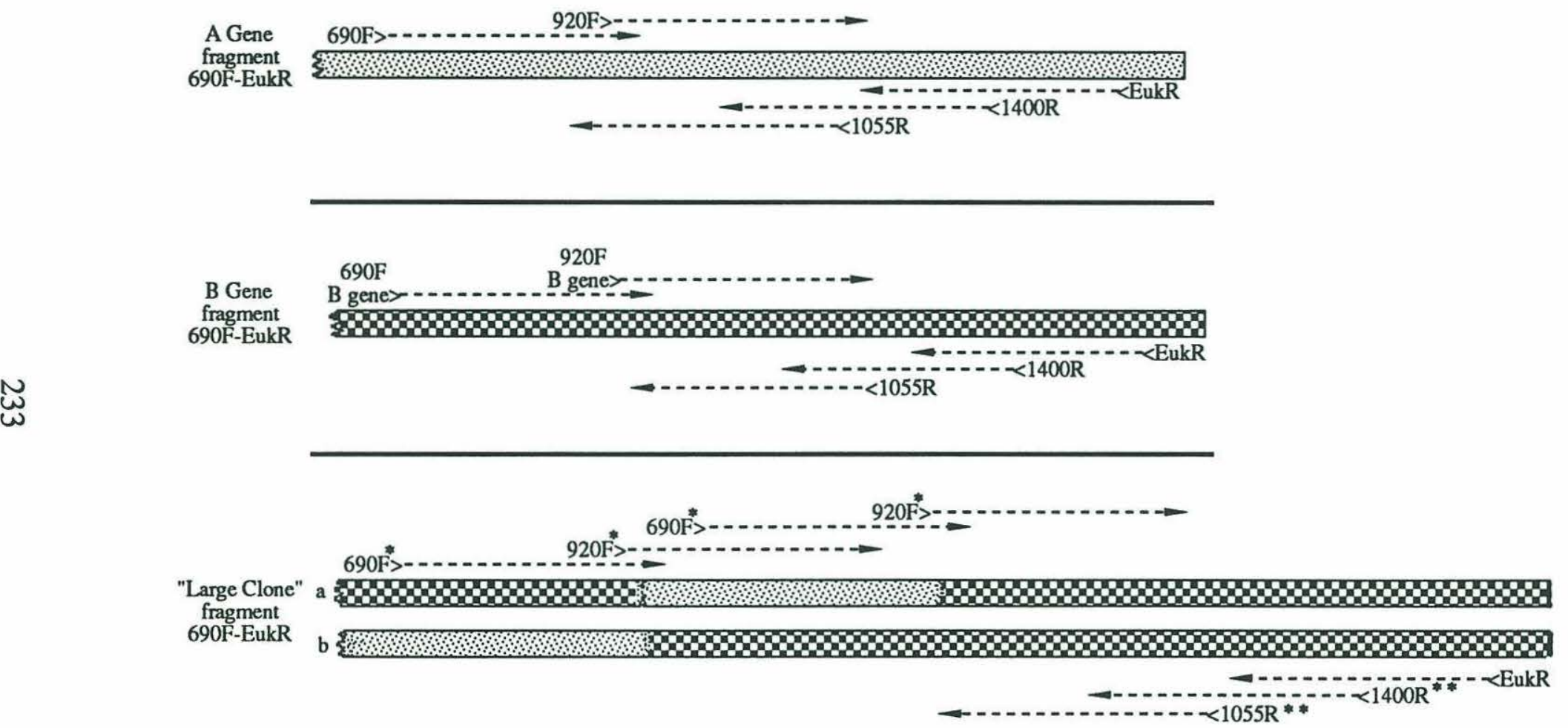

Figure B.6. Schematics showing the "690-EukR" fragments for the A gene, B gene, and possible configurations of GtPP01's "partial SsrDNA Large Clone" $(\mathrm{a}, \mathrm{b})$. The relative positions of sequencing primers used to characterize the position of the insert are shown; the polarity of the sequences are indicated by arrows. Individual "partial SsrDNA Large Clone" analyses: "*" = sequences that always yield A/B gene heterogeneity and "insert" characteristics with equal intensity; "**" = sequences that yield a single sequencing ladder with B gene characteristics (see Fig. B.5). 
234 
Appendix C: LsrDNA Notes 


\section{Description of Alexandrium Subribotypes}

updated $10 / 13 / 92$

North American Ribotype

Subribotype $\quad \underline{\text { SsrDNA RFLP Group }} \underline{\text { Unique LsrDNA Characteristics }}$

eastern Group I 590/591 TG deletion present

western $\quad$ Group II 590/591 TG deletion $\underline{\text { absent }}$

alternate $\quad$ Group II $\quad$ 590/591 TG deletion present;

seq. diff. at pos. 393-354

North American Subribotype Notes:

Additional length and sequence heterogeneities were observed among members of the North American group, but are not reported here; it is impossible to know if they are the result of PCR error, or due to clonal biasing. Evidence that such variations are representative of true genomic variation is weak without confirmation by repeated PCR and sequencing. Extremely fine-scale variation between localized populations of eastern or western North American isolates may exist, but has not been resolved in this study. Approaching this experimentally wi. be tedious given the minimal variation that is expected. One possibility is to use the magnetic bead sequencing technique, to more effectively sample the PCR pool and eliminate concerns of clonal biasing. Differences will most likely appear as length heterogeneities or ambiguities at defined locations. With highly redundant efforts, it should be possible to prove if these are valid characters. If such marker are identified, they could prove of value in population dynamic studies. 


\section{Temperate Asian Ribotype}

Subribotype SsrDNA RFLP Group Unique LsrDNA Characteristics

Japanese Group III (Temperate Asian reference)

Korean Group III length heterogeneity pos 222

ambiguities

sequence difference at pos. 39

Temperate Asian Subribotype Notes:

Only minor length and sequence heterogeneities were seen among members of the Japanese subgroup. These differences are not shared among all isolates, and thus collectively this group appears "heterogeneous." Interpretation of these differences is problematic for the same reasons noted above. Note that protein electrophoretic comparisons of a number of $\underline{A}$. catenella isolates (ACPP01, 02. 03, 09, and ACJP03) also reveal heterogeneity (Hallegraeff, pers. comm.). I found the ACPP series to be identical, except for the positions of minor length heterogeneities.

The length heterogeneity in the Korean group looks severe - possibly several bp difference? inversion/insertion? Whatever it is, it's near the 3' border of the D1 domain. At first I thought it was a contaminate, but the $\mathrm{D} 2$ reads are clean. This indicates heterogeneity, not contamination. Also, it showed up in both G. Hope 1 and 2; these cultures were processed in completely different batches. I sequenced two individual clones from G.Hope 1, but unfortunately picked the same one twice so the nature of this heterogeneity is not fully resolved. My gut feeling is that the Japanese/Korean differences are evolutionarily-equivalent to eastern/ western/alternate differences, only their divergence is more recent. 


\section{Notes on Alexandrium LsrDNA Sequence Alignment}

The 5 ' portion of the aligned molecules are relatively similar, despite the fact that this region of the LsrDNA encompasses the D1 variable domain. Alignment of the more distal portion of the clones, covering the hypervariable D2 domain, requires the insertion of gaps and is more problematic (cf. Chapt. 3). This is not surprising as the D2 domain is reported to be one of the most variable within the LsrRNA and subject to the greatest length variations (Mitchot and Bachellerie 1987) ${ }^{1}$. Theoretical secondary structures were created for each of D1 and D2 domains in an effort to assess the accuracy of the proposed alignment. Secondary structures can improve an alignment if the divergent sequences conform to similar folding patterns. When they do, the structures indicate which sequence positions are equivalent and also help dictate the location of alignment gaps (Olsen 1988). ${ }^{2}$

In an effort to test the alignment presented in Chapt. 3, theoretical secondary structures of the hypervariable D1 (positions 75-225) and D2 (positions 350-675) domains for each representative ribotype were compared. Two different methods were used, both of which employed the $\underline{\text { P. micans }}$ D1 and D2 models

\footnotetext{
${ }^{1}$ Mitchot, B., Bachellerie, J.P. (1987). Comparisons of large subunit rRNAs reveal some eukaryote-specific elements of secondary structure. Biochimie 69:11-23.

2 Olsen, G. J. (1988). Phylogenetic analysis using ribosomal RNA. Methods in Enzymol. 164: 793-812.
} 
(Lenaers et al. 1989) ${ }^{3}$ as a reference. First, the $\underline{P}$. micans structure was used directly as template to position the new sequences and determine if compensating base pair changes occurred in the stem structures. Second, theoretical structures were generated using the Zucker and Stiegler folding program (MacDNASIS Pro V.1.0, Hitachi) and then superimposed on the $\underline{P}$. micans structures, as well as those derived for other Alexandrium isolates.

Alexandrium D1 domains appear to be structurally similar to each other as well as to that proposed for $\underline{P}$. micans, thus their alignment as shown in Fig. 2 seems justified. However, theoretical Alexandrium D2 structures appear different from each other, and from their counterpart in $\underline{\mathrm{P}}$. micans. Secondary structures can be devised for each of the ribotype's D2 sequences, but none conceived thus far gives rise to consistent, compensating base pair changes in a structure similar to those proposed by Mitchot and Bachellerie (1987) and Lenaers et al. (1989). This may indicate a relatively divergent structure, even for closely-related species or strains of single species (Noller, pers. comm.). In the absence of more advanced computer-assisted analyses, it has not been possible to produce a structure suitable for testing the distal portion of the proposed alignment. The discrepancy between the two halves of the molecule probably reflect the fact that the D1 domain is more highly conserved, and its sequences from a number of dinoflagellates have

${ }^{3}$ Lenaers, G., Maroteaux, L., Michot, B., Herzog, M. (1989). Dinoflagellates in evolution. A molecular phylogenetic analysis of large subunit ribosomal RNA. J. Mol. Evol. 29:40-51. 
been rigorously compared (Lenaers et al. 1991). The D2 domain, on the other hand, is more highly divergent and its sequences have not been extensively analyzed for many dinoflagellate species. The alignment in Chapt. 3 should therefore be considered a working model. Multiple attempts have been made to refine it, and each of these revisions have been subjected to phylogenetic analysis. In all cases, the existence of the same distinct groups of Alexandrium isolates is clearly indicated. 


\section{Interpretation of Fine-Scale Alexandrium LsrDNA Sequence Variations}

\section{INTRODUCTION}

PCR amplification, cloning and sequencing of rDNA can be problematic. These genes are ubiquitous among living organisms and the primers used in their amplification will cross react with a wide range of species. Thus, the potential for contamination is ever present, even with fastidious execution of experimental protocol. The processes of amplifying, cloning and sequencing rDNA can also yield artifacts because of methodological errors (e.g., "mistakes" during the PCR reaction, clonal biasing, sequence compressions, etc). Heterogeneity within an organism's complement of rDNA may also exist. A further complication is that some rDNA may be expressed, and some may not.

Accurate documentation of sequence heterogeneity that occurs both within and between organisms is of key importance if the sequences are to be useful in phylogenetic analyses, and as references for developing RFLP assays or for constructing oligonucleotide probes. Consequently, the distinction between "artifactual heterogeneity" and "genomic heterogeneity" is critical, especially when comparing sequences that vary only slightly from one another. Since micro-scale rDNA heterogeneity holds the key to many applications in Alexandrium population biology, one must be cautious interpreting and documenting fine-scale sequence 
differences. If cloning is necessary, multiple clones must be pooled prior to sequencing, the reproducibility of a particular sequence character should be established and the effects of clonal biasing (see below) need to be taken into consideration.

The following discussion and accompanying figures are intended to provide examples of heterogeneities found during the sequence analysis of Alexandrium LsrDNA clones. Some attention is given to distinguishing between contamination versus genomic variation, as well as interpreting and resolving particular sequence ambiguities and length heterogeneities. This is not an exhaustive treatise; however, the salient features of difficulties that arose during this thesis are presented.

\section{Alexandrium LsrDNA Genomic Heterogeneity}

LsrDNAs from some Alexandrium cultures contained ambiguities and length heterogeneities (Chapt. 3). At times this made complete, unambiguous sequence determinations difficult or impossible without analyzing individual LsrDNA clones. Hypotheses put forth to explain this variation included: 1) methodological artifact(s); 2) presence of a contaminating source of eukaryotic DNA; 1 and/or, 3) intracellular genomic variation.

\footnotetext{
1 bacterial or plastid contamination was not considered since the PCR primers are specific for eukaryotes
} 


\section{Methodological Artifacts}

The possibility of methodological artifact was addressed by amplifying, cloning and sequencing LsrDNAs from PW06 (․․ tamarense) on two separate occasions. The methods do yield an overall reproducible result since both sequences were found to be $>99 \%$ identical. However, each set of PW06 clones was found to harbor its own, unique sequence ambiguity. Thus, minor sequence differences are arising during the PCR, cloning and/or sequencing processes. PCR artifact cannot be ruled out in this case. In addition, the sequence differences could stem from a combination of actual genomic variability and "clonal biasing." That is, the observed ambiguities or length heterogeneities depend on the random assortment of clones chosen for analysis from a pool of faithfullyreproduced, albeit microheterogeneous, rRNA genes (this is discussed in greater detail below). In the case of PW06, one round of cloning yielded 5 recombinants, the second 7 . Since so few clones have been sampled in both instances, it is impossible to decide which sequence is "most correct," and so neither discrepancy was reported.

The combination of methodological artifacts (e.g. PCR error), genomic variation and clonal biasing will therefore introduce errors!! In Alexandrium LsrDNA sequence determinations there is the potential for at least $\sim 1 \%$ error, even if all all other determinations are perfect. Comparing many isolates from the same genetic population helps in catching some of these mistakes; or at least, helps you to decide if an ambiguity or length heterogeneity should be 
recorded, or ignored (see below). At the very least, the observed heterogeneity highlights the danger of using a single or even a few rDNA clones from these organisms to ascertain a representative sequence. In this study, sequences from isolates represented by few clones were interpreted with caution.

\section{Contamination versus Genomic Variation}

The sequences of the D1 and D2 hypervariable domains can be used to distinguish between genomic (or PCR product) heterogeneity and contamination. Because these regions are known to be evolutionarily-variable, one would expect a contaminated Alexandrium DNA preparation (e.g., with fungal DNA) to yield completely incongruous sequencing ladders in the D1 and D2 regions, but "normal" sequencing ladders in the conserved regions flanking these hypervariable domains. This is observed reading from a conserved region through a variable region: the sequencing ladder will appear unique (or with little variation) and then suddenly "split" into two (or more) distinct sequences as the sequences extend into the variable domain. In contrast, true genomic variants within a hypervariable domain appear as a point mutations: an ambiguity should occur at a unique position while the primary sequence remains constant; a length heterogeneity should result in two identical sequencing ladders which are simply displaced by one or more nucleotides, giving the impression that one sequence "lags behind the other." In almost all cases, the heterogeneity observed in the Alexandrium cultures fit the criteria of clonal variants and not 
contamination. ${ }^{2}$ Finally, I noted that certain groups of isolates share identical point heterogeneities among their LsrDNA clones; this is consistent with genomic variants that are shared among closelyrelated isolates.

\section{Intra-Organismal LsrDNA Variation}

The best examples of LsrDNA genomic variants and and clonal biasing are seen in the D1 and D 2 hypervariable regions. Figure C.1 shows pooled clone sequences from a number of isolates' D1 regions. This gel was chosen for several reasons. It provides examples of sequence and length heterogeneities, as well an example of clonal biasing. When many cultures are compared, length heterogeneities and ambiguities characteristic of a particular group of cultures become evident. An example of this is seen in Fig. C.1 for AFNFA3, GtCA29 and GtCN16. Only after many cultures are examined do the effects of clonal biasing become evident: in some cases, a pool of LsrDNA clones would only exhibit a trace of an ambiguity, while in others the ambiguities could appear dramatic (e.g., compare GtCA29 and $\mathrm{GtCN} 16)$. This can be used to help deduce the nature of an ambiguity or length heterogeneity, and its effects on the sequencing ladder. It is also useful for determining if ambiguities should be recorded, or ignored.

2 contamination was observed on rare occasion; the most notable case was the author's own rDNA that was inadvertently introduced into a PCR reaction from a peeling sun burn. No kidding. Fungus was also a sporadic problem in early sequence determinations. The contaminated DNA and cultures were discarded, and from that point on great care was taken in examining the cultures prior to harvest and extraction. 
The most dramatic example of length heterogeneities were found in all cultures of $\underline{\mathrm{A}}$. $\underline{\text { tamarense }}$ and $\underline{\mathrm{A}}$. $\underline{\text { fundyense }}$ from eastern

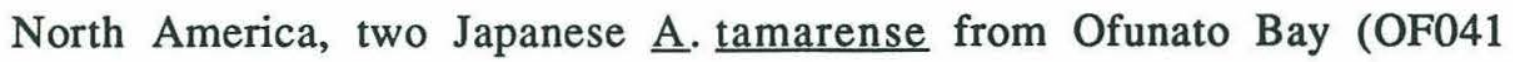
and OF051) and two ballast water $\underline{A}$.tamarense (I72/21\#2, I72/21\#4; Chapt.3), a total of sixteen different cultures. LsrDNA clones from these organisms display an identical two base pair length heterogeneity (TG deletion) at positions 590-591; this mixture causes the sequencing ladders to become out of register distal to the deletion and obscures sequence determinations of the $3^{\prime}$ half of the molecules. Individual LsrDNA clones from several isolates were sequenced to resolve the ladders. An example of pooled and individual sequences covering the 590-591 region of AFNFA3 are presented in Fig. C.2 ("reverse reactions;" sequences are the complement of the non-coding strand). Analysis of individual LsrDNA clones showed this heterogeneity to result from two distinct copies of the gene: those which carry the 590-591 TG deletion, and those that do not. Clonal biasing around the 590-591 region was also evident. Figure C.3 shows an example of this. Note how the sequencing ladders in Fig. C.3 emphasize the same two variants of the sequence shown in Fig. C.2. 


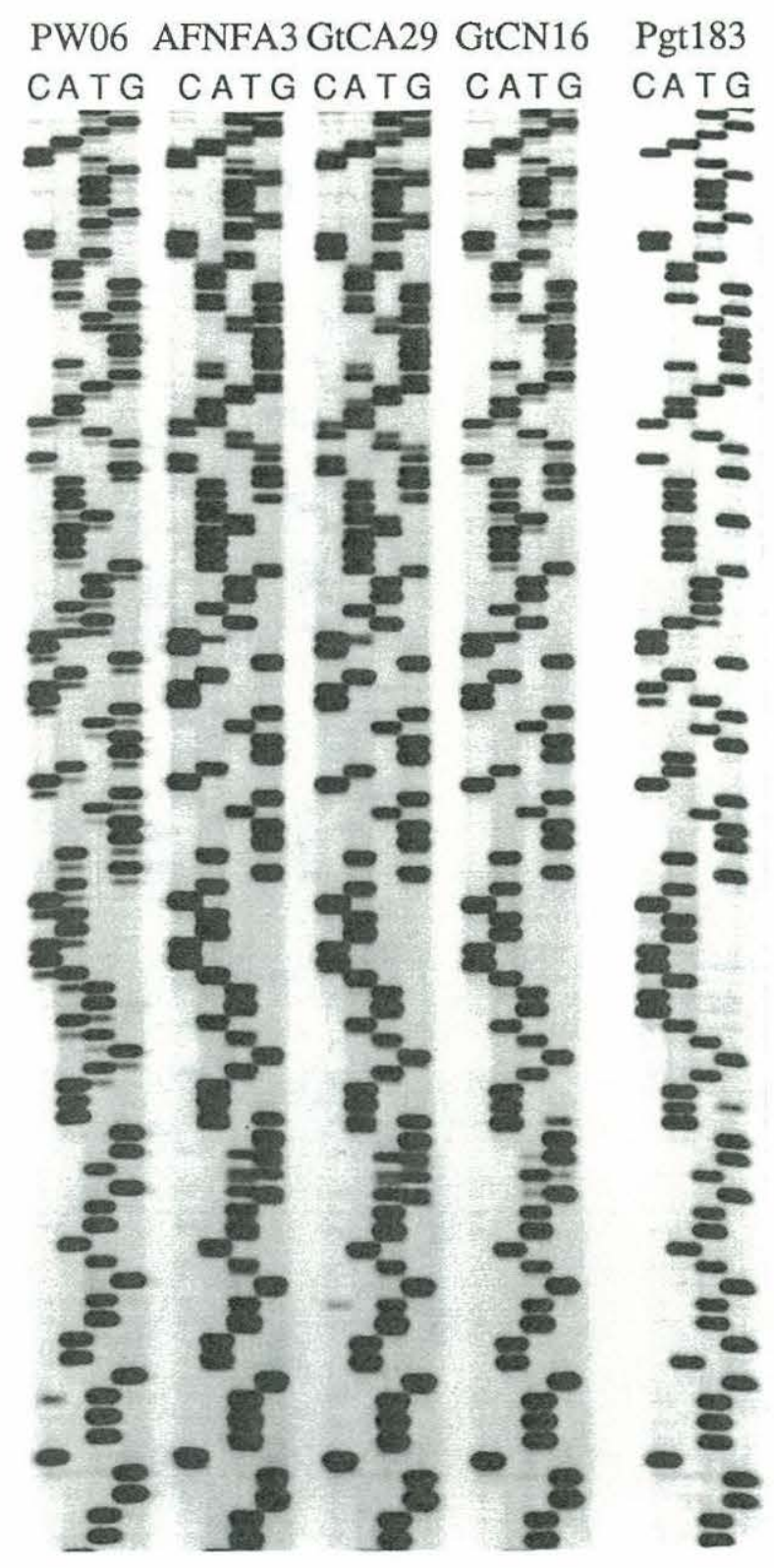

Figure C.1. Examples of length hetergeneities, ambiguitties and clonal biasing observed in LsrDNA clones from the indicated isolates.

Sequences are from pooled clones using the D1R primer. Region of sequences shown extends from positions $\sim 86$ (bottom) to $\sim 189$ (top).

Note the difference in the position of the length heterogeneities found in PW06 (from western North America) and AFNFA3, GtCA29, GtCN16 (all from eastern North America). Also note an example of clonal biasing between AFNFA3/GtCA29 and GtCN16. 
AFNFA3
pooled clones

CA T G

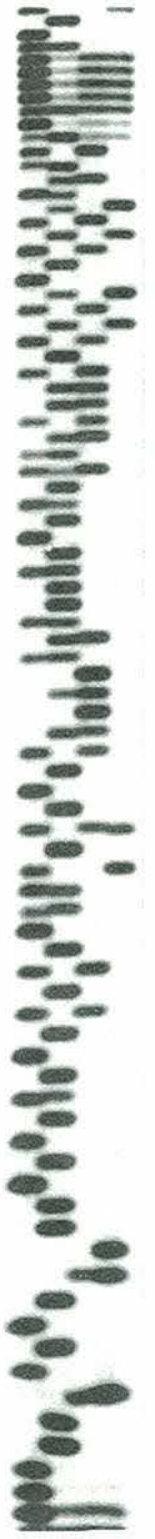

AFNFA3

individual clones

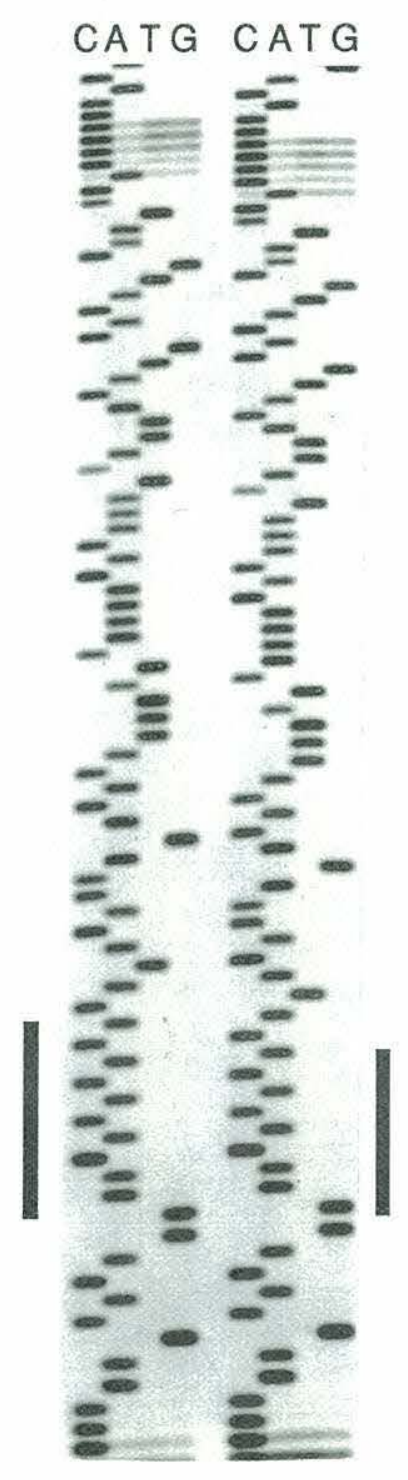

Figure C.2. Example of LsrDNA 590-591 TG length heterogeneity as seen in pooled and individual LsrDNA clones from AFNFA3 when sequenced using the D2C primer (reverse reaction; cf. Chapt. 3). Dark bars indictate the location of the heterogeneity. The region of sequence shown extends from positions $\sim 606$ (bottom) to $\sim 516$ (top). 


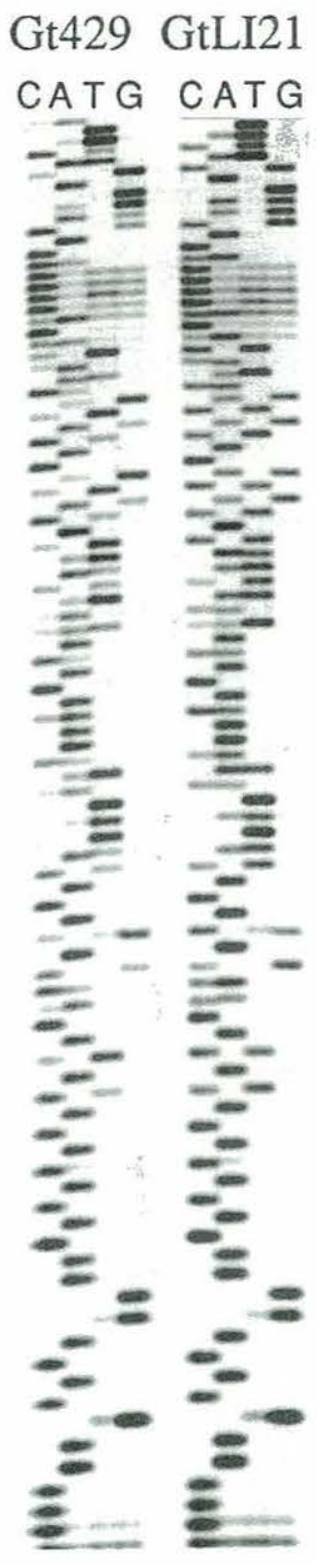

Figure C.3. Example of clonal biasing in the region of the 590-591 LsrDNA TG deletion. Sequences are from pooled clones of Gt429 and GtLI21 using the D2C primer. Region of sequence shown extends from positions $~ 606$ (bottom) to $\sim 510$ (top). 
Genomic Variation versus Expressed Variation.

Variation that may exist within an organism's complement of rDNA genes may not be expressed. An example of this was documented in Chapt. 1. The question of expression is important in developing assays to detect micro-scale rDNA heterogeneity, such as the application of rRNA-targeted probes. If ambiguities in a targeted region are present in the DNA, then it must be determined if the same ambiguities exist in the RNA, or if the RNA exists at all. If the sequence of interest is not expressed, or only at vanishingly low levels, then any assay designed to detect it will have to be DNAbased, such as RFLP or sequence analyses. An example of this was documented in Chapt. 2.

In the case of the LsrDNA 590-591 TG deletion, both variants appear to be expressed (Fig. C.4). Unfortunately, a break in the RNA backbone slightly downstream of the D2C primer precluded a better view of the two variants, but upon comparing BGt1 (no TG deletion) and CA29 (with TG deletion) the expected differences are evident. 


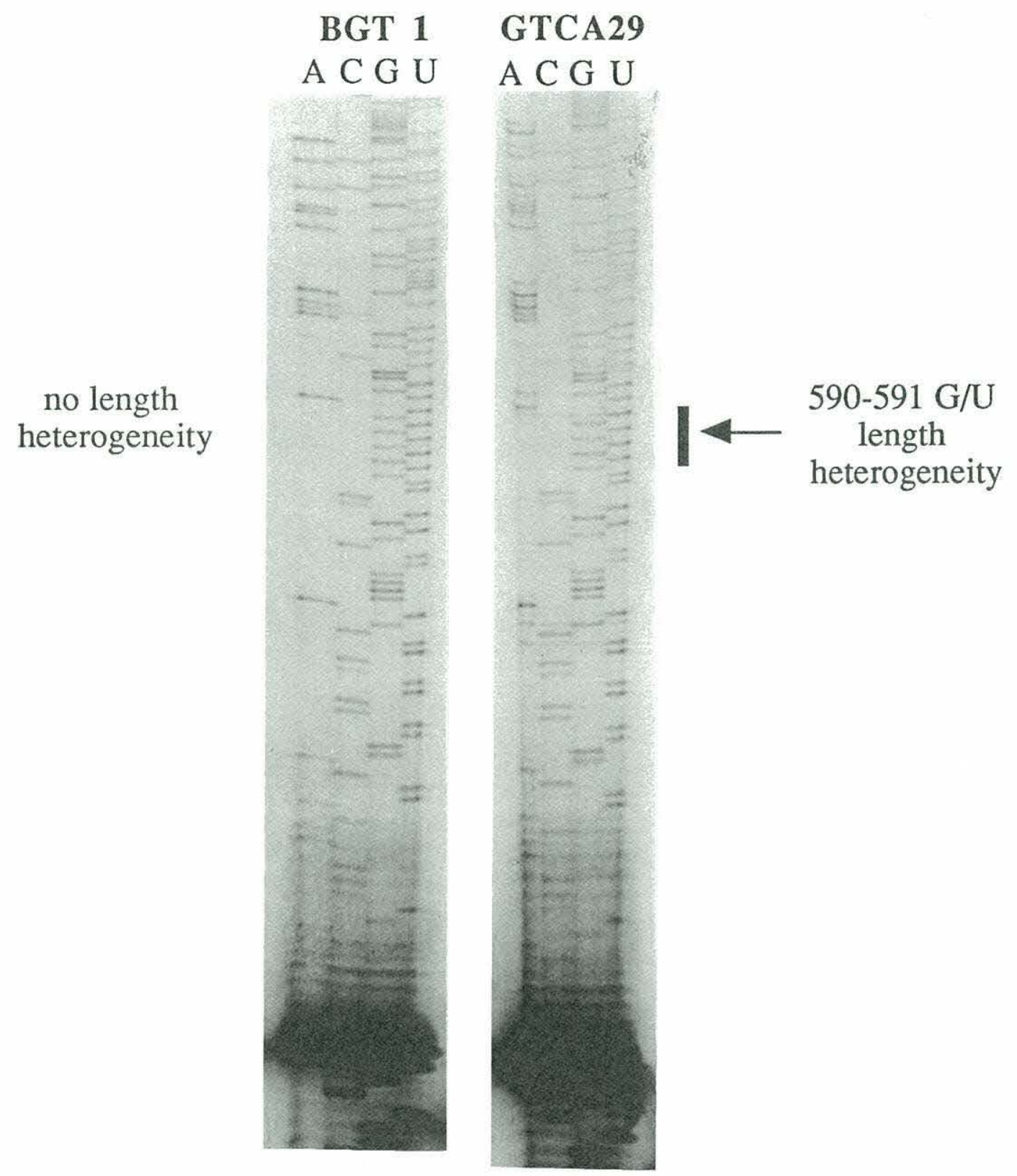

Figure C.4. Over exposure of D2-primed RTase sequences obtained from total RNA extracts from BGt1 and CA29. The complement of specific nucleotide termination reactions are indicated above each lane. A nick in the RNA backbone causes termination of the sequencing ladder slightly downstream of the primer, but traces of sequencing ladders are still evident. Readable sequence begins at position $\sim 630$ (bottom) and extends to $\sim 520$ (top) in Bgt1. Dark bar indicates location of 590-591 G/U length heterogeneity; note how GtCA29's sequence becomes out-of-register beyond this point, while BGt1's does not. 